PEDRO IVO GRICOLI IOKOI

\title{
A APREENSÃO NO PROCEDIMENTO DOS CRIMES CONTRA A PROPRIEDADE IMATERIAL
}

Orientador: Prof. Antonio Scarance Fernandes

UNIVERSIDADE DE SÃO PAULO

FACULDADE DE DIREITO

SÃO PAULO

2013 


\section{A APREENSÃO NO PROCEDIMENTO DOS CRIMES CONTRA A PROPRIEDADE IMATERIAL}

Tese apresentada ao Programa de PósGraduação em Direito da Faculdade de Direito da Universidade de São Paulo como requisito parcial para obtenção do título de Doutor em Direito.

Área de concentração: Direito Processual.

Orientador: Prof. Antonio Scarance Fernandes

UNIVERSIDADE DE SÃO PAULO

FACULDADE DE DIREITO

SÃO PAULO

2013 
Dedico este trabalho ao meu avô, Taro Yokoi (in memorian), amigo e herói.

Dedico-o, igualmente, ao meu orientador, professor Antonio Scarance Fernandes, pelo exemplo de pessoa e mestre a ser seguido por todos os seus alunos.

Dedico-o, por fim, aos meus filhos, José Pedro Iokoi e Henrique Iokoi, razões da minha vida, e à minha esposa, pela paciência e pela cumplicidade. 


\section{AGRADECIMENTOS}

Aos professores José Raul Gavião de Almeida e Maurício Zanoide de Morais, examinadores da comissão julgadora de qualificação, pelas importantes críticas à estrutura deste trabalho, que instigaram o aperfeiçoamento do presente estudo.

Aos demais professores das disciplinas cursadas no programa de pós-graduação, Antonio Magalhães Gomes Filho, Gustavo Henrique Righi Ivahy Badaró, Maria Thereza Rocha de Assis Moura, José Rogério Cruz e Tucci, Balmes Vega Garcia e Newton Silveira.

Aos meus amigos Adriano Scalzaretto e Ilana Muller, pelas críticas e pelas contribuições ao presente trabalho.

Aos meus colegas de pós-graduação, pelo companheirismo e pela amizade travados nos bancos acadêmicos.

Aos meus amigos e colegas da Subsecção de Pinheiros da OAB-SP, pela confiança.

Aos meus amigos de todos os dias Eduardo Soutello, Rodrigo Pereira, Fabio Caldeira, Bruno Paiva, Gustavo Jonasson, Thais Vasconcellos, Caio Fonseca, Edilson Bonfim, Tiago Borelli, Lucas Borelli, Fernando Seabra, Tomaz Gouvêa, André Lima, Luiz Guilherme Conci, Edemilson Vicente, Paulo Camargo, João Biazzo, Alfredo Zucca, Mauricio Giannico e Bruno Burini.

Aos meus pais e à minha irmã, pela amizade e apoio. À minha família. 


\section{RESUMO}

À luz do princípio da presunção de inocência, construiu-se o entendimento de que no processo penal seriam lícitas apenas as medidas cautelares, em respeito ao status de inocência do acusado, vedando quaisquer outras medidas que revelassem uma antecipação do juízo condenatório. Partindo dessa premissa, as medidas de busca e apreensão passaram a ser entendidas e aceitas apenas como medidas cautelares, destinadas a assegurar a marcha processual ou a eficácia e a utilidade do provimento jurisdicional final. Entretanto, com a promulgação da Lei $\mathrm{n}^{\mathrm{o}} 10.695 / 2003$ - que modificou a proteção penal da propriedade imaterial e criou um novo procedimento especial para os crimes de ação penal de iniciativa pública —, foi introduzida no sistema uma nova modalidade de apreensão, permitindo o apossamento de todos os bens ilicitamente produzidos ou reproduzidos, com o escopo de tornar o combate à pirataria mais eficiente. Assim, a nova medida deixou de ser um instrumento a serviço do processo e passou a ter um novo objetivo: dar resposta à sociedade com a apreensão, antes mesmo da produção da prova pericial, dos bens contrafeitos, revelando natureza jurídica de medida de antecipação de tutela (satisfativa). Entretanto, apesar de ter natureza jurídica satisfativa, a medida de apreensão prevista no artigo 530-B do Código de Processo Penal se justifica no nosso sistema e não representa violação ao princípio da presunção de inocência, por se referir a capítulo da sentença distinto do capítulo da autoria e da culpabilidade do acusado: refere-se ao capítulo das coisas que não podem ser restituídas. Nessa situação, tanto em casos de condenação quanto em casos de absolvição, impronúncia ou arquivamento, as coisas não podem ser restituídas porque o fabrico, a alienação, o porte ou a detenção constitui por si só fato ilícito autônomo. Logo, a antecipação de tutela determinando a apreensão de tais coisas não representa violação ao princípio da presunção de inocência. Por outro lado, o procedimento deve ser modificado para alcançar o justo equilíbrio entre a eficiência e o garantismo, introduzindo a obrigação de que a ilicitude seja constatada, por perito ou pessoa tecnicamente habilitada, logo após a apreensão e de que a medida seja sempre precedida de ordem judicial - ou, nos casos de prisão em flagrante, seja imediatamente submetida à apreciação judicial, para que seja convalidada ou revogada.

Palavras-chave: Processo penal. Eficiência e garantismo. Apreensão. Pirataria. Medida satisfativa. 


\begin{abstract}
Under the light of assumption of innocence, it was understood that in the criminal suits there would only be acceptable caution measures regarding the status of innocence of the accused, prohibiting any other measures revealing an advanced position of the condemning judgment. As of this assumption, the search and seizure measures started to be understood and accepted only as caution measures, destined to assure the procedural progress or the effectiveness and usefulness of the final jurisdictional decision. However, with the enactment of Law 10695/2003 - which modified the criminal protection of intangible property and created a new special process for criminal suits of public initiative - a new kind of seizure was introduced, allowing the possession of all assets produced or reproduced illicitly, with the scope of rendering more efficient the fighting against piracy. Thus, the new measure stopped being an instrument to serve the suit and evidenced a new purpose, of providing answers to the society with the seizure of the infract assets, even before the production of the expert's evidence, revealing legal nature of advanced protection (satisfactory). However, in spite of having the legal nature of satisfaction, the seizure measure provided by article 530-B of the Criminal Procedures Code is justified in our system and does not represent infringement of the principle of assumption of innocence, since it refers to a chapter of the sentence different from the chapter of authorship and guilt of the accused, i.e., refers to chapter of things which cannot be returned. In these cases of things which cannot be returned, both in case of condemnation and acquittance, lack of judgment or filing, the things cannot be returned because the manufacture, disposal, possession or holding thereof, in itself, constitutes and independent illicit fact. Therefore, the advanced protection determining the seizure of such things does not represent infringement of the principle of assumption of innocence. On the other hand, the procedure must be modified to achieve fair balance between the efficiency and the guaranteeism, introducing the obligation of the forgery being evidenced by official expert or technically qualified person, straight after the seizure; and that the measure is always preceded by judicial order, or in cases of imprisonment in flagrant, that it is immediately submitted to judicial analysis, for the measure to be validated or revoked.
\end{abstract}

Keywords: Criminal procedure. Efficiency and guaranteeism. Seizure. Piracy. Satisfying measure. 


\section{RIASSUNTO}

Alla luce del principio della presunzione di innocenza, si è costruita l'intesa che nel processo penale sarebbero lecite soltanto le misure cautelari, in rapporto allo status di innocenza dell'accusato, vietando qualsiasi altra misura che rivelasse un'antecipazione del giudizio di condanna. Partendo da questa premessa, le misure di ricerca e perquisizione sono state comprese ed accettate solo come misure cautelari, destinate ad assicurare l'andamento processuale o l'efficacia e l'utilità del provvedimento giudiziale finale. Con l'entrata in vigore della Legge 10.695/2003 - la quale ha modificato la protezione penale della proprietà immateriale ed ha creato una nuova procedura speciale per i delitti di azione penale nella pubblica gestione -, è stata, però, introdotta nel sistema una nuova modalità di perquisizione, permettendo la detenzione di tutti i beni prodotti o riprodotti illecitamente, allo scopo di far diventare più efficiente il combattere delle contraffazioni. Così, la nuova misura ha cessato di essere uno strumento a servizio del processo e ha iniziato ad avere un nuovo obiettivo, a dare una risposta alla società attraverso la perquisizione dei beni contraffatti, prima ancora della produzione della prova periziale, rivelando la natura giuridica della misura di antecipazione della tutela (per garanzia). Intanto, nonostante abbia la natura giuridica di garanzia, la misura di perquisizione prevista dall'articolo 530-B del Codice di Procedura Penale si giustifica nel nostro sistema e non rappresenta violazione al principio della presunzione di innocenza, per riferirsi al capitolo della sentenza diverso dal capitolo di autore del fatto e di colpevolezza dell'accusato, cioè, si riferisce al capitolo delle cose che non possono essere restituite. In questi casi, ossia, delle cose che non possono essere restituite, sia nel caso di condanna che in caso di assoluzione, mancato pronunciamento ou archiviazione, le cose non possono essere restituire perchè la produzione, alienazione, possedimento o detenzione, costituiscono per se stessi il fatto illecito autonomo. Pertanto, l'antecipazione della tutela determinando la perquisizione di tali cose non rappresenta violazione al principio della presunzione di innocenza. D'altro canto, la procedura deve essere modificata per raggiungere il giusto equilibbrio tra efficienza e garantismo, introducendo l'obbligazione che l'illecito sia costatato da un perito o da una persona tecnicamente abilitata per farlo, subito dopo la perquisizione del bene; e inoltre, che la misura sia sempre preceduta da ordine giudiziale, o nei casi di arresto in flagrante, sia immediatamente sottomessa alla valutazione giudiziale, affinchè la misura sia convalidata o sospesa.

Parole-chiave: Procedura penale. Efficienza e garantismo. Sequestro Probatorio. Pirateria. Misura di garanzia. 


\section{SUMÁRIO}

INTRODUÇÃO. 10

CAPÍTULO I - PROTEÇÃO DA PROPRIEDADE INTELECTUAL …………………….... 15

1.1 BREVE HISTÓRICO DA PROTEÇÃO DA PROPRIEDADE INTELECTUAL_............................. 15

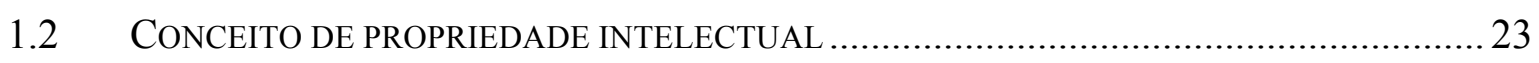

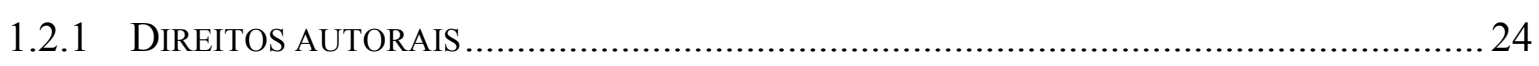

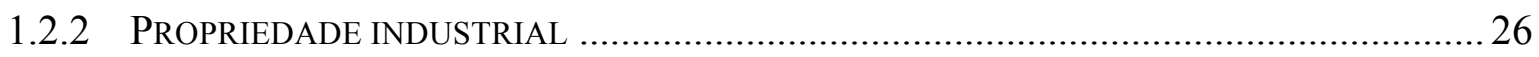

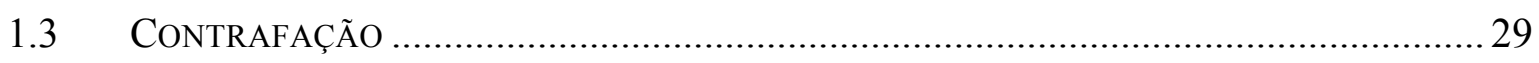

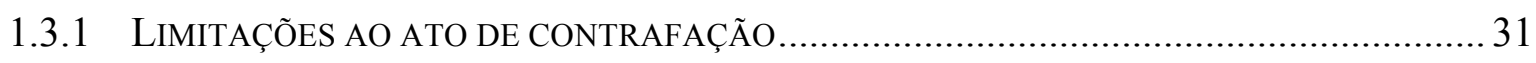

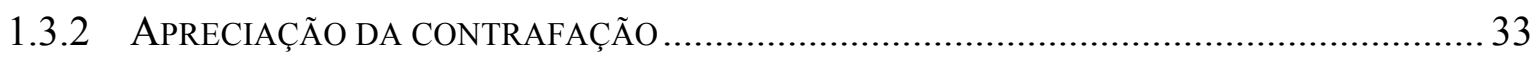

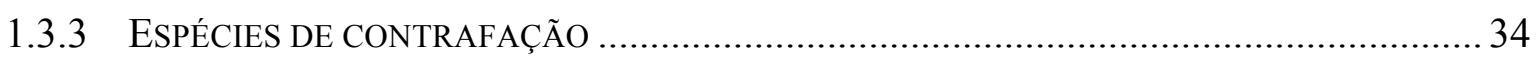

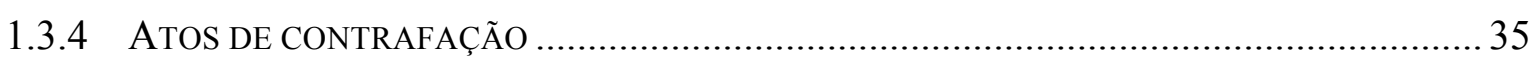

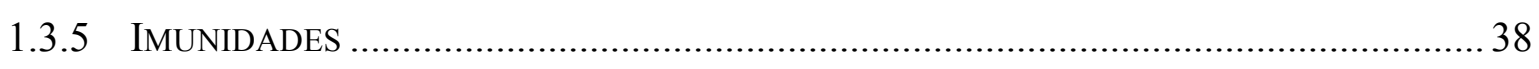

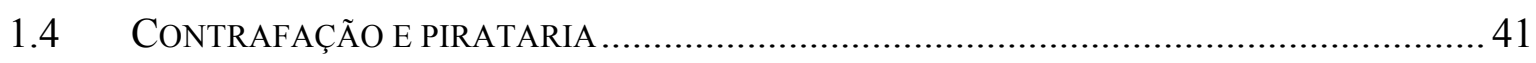

CAPÍTULO II - PROTEÇÃO PENAL DA PROPRIEDADE INTELECTUAL.................. 46

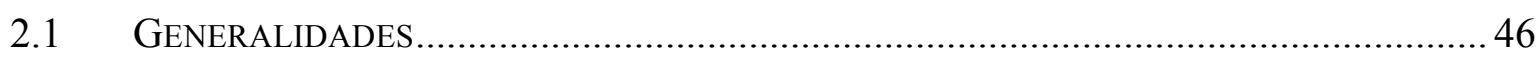

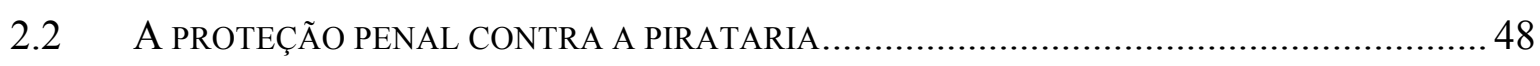

2.2.1 O COMBATE À PIRATARIA E A LEI DO CRIME ORGANIZADO ……...................................52

2.2.2 O COMBATE À PIRATARIA E A LEI DOS CRIMES DE LAVAGEM DE DINHEIRO..................56

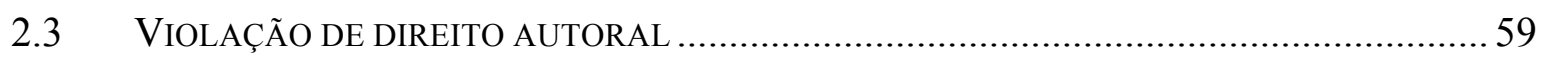

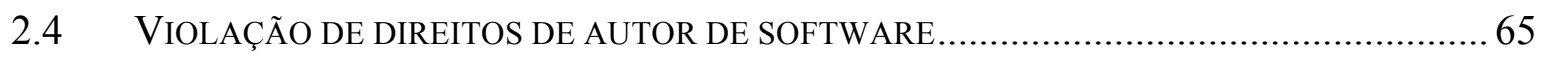

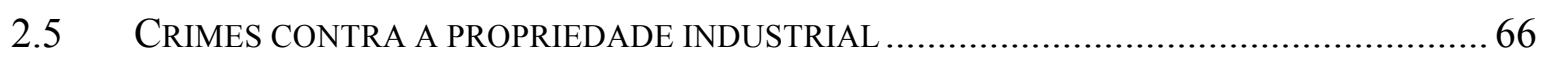

2.6 AUSÊNCIA DE ISONOMIA NA PROTEÇÃO PENAL DA PROPRIEDADE IMATERIAL .............70

CAPÍTULO III - DA BUSCA E DA APREENSÃO …………………………………......... 74

3.1 A BUSCA E A APREENSÃO NA LEGISLAÇ̃̃o BRASILEIRA............................................. 74

3.2 LIMITES CONSTITUCIONAIS DA BUSCA E DA APREENSÃO ............................................ 76

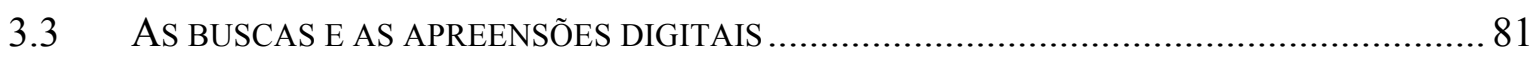

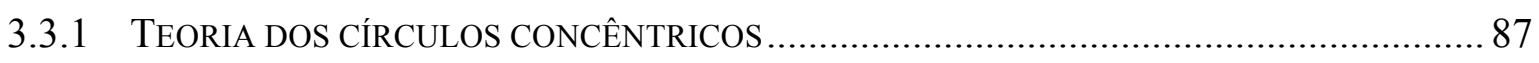

3.4 A BUSCA E A APREENSÃO NO DIREITO COMPARADO …………............................... 90

3.4.1 A BUSCA E APREENSÃO NO DIREITO PROCESSUAL PENAL ESTADUNIDENSE ................ 91

3.4.2 A BUSCA E A APREENSÃO NO DIREITO PROCESSUAL PENAL ARGENTINO ...................... 94

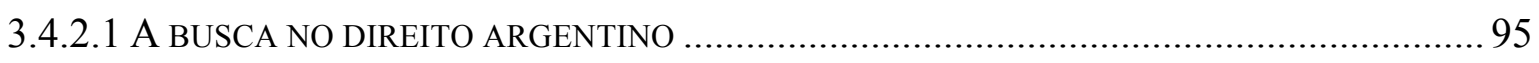

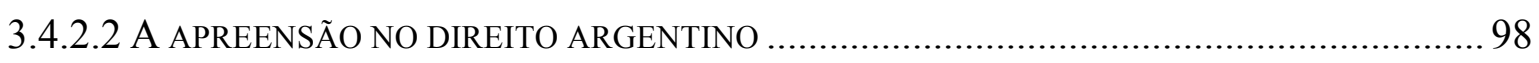

3.4.3 A BUSCA E A APREENSÃo NO DIREITO PROCESSUAL PENAL ITALIANO ....................... 101 
3.4.3.1 A INSPEÇÃO NO DIREITO ITALIANO 102

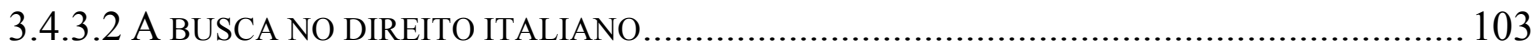

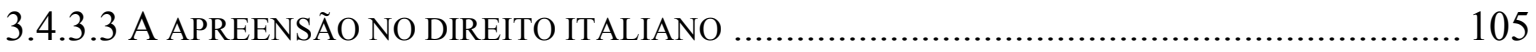

CAPÍTULO IV - A APREENSÃO NO PROCEDIMENTO COMUM E NO PROCEDIMENTO DOS CRIMES CONTRA A PROPRIEDADE IMATERIAL 108

4.1 A BUSCA E A APREENSÃO COMO INSTITUTOS AUTÔNOMOS......................................... 108

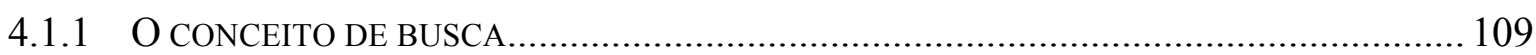

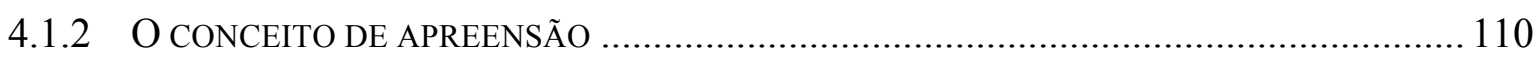

4.1.3 FonTE DE PROVA, MEIO DE PROVA E MEIO DE OBTENÇ̃̃o DE PROVA.......................... 111

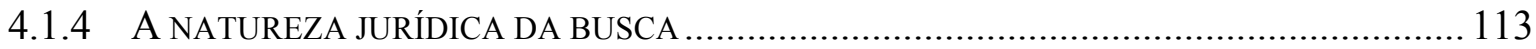

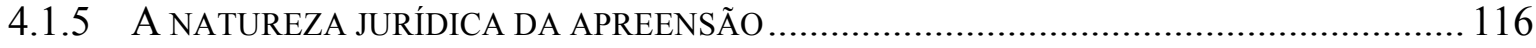

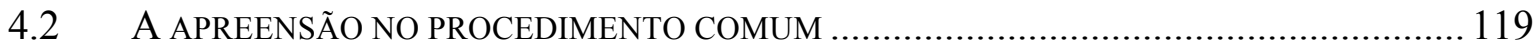

4.3 O PROCEDIMENTO DOS CRIMES CONTRA A PROPRIEDADE IMATERIAL......................... 123

4.3.1 O PROCEDIMENTO DOS CRIMES DE AÇ̃̃o PENAL DE INICIATIVA PRIVADA................... 124

4.3.2 O PROCEDIMENTO DOS CRIMES DE AÇ̃̃o PENAL PÚBLICA ………………………....... 129

4.3.3 A APREENSÃO NOS CRIMES DE AÇÃO PENAL PRIVADA …………………………….... 133

4.3.4 A APREENSÃO NOS CRIMES DE AÇÃO PENAL PÚBLICA …………………………....... 135

CAPÍTULO V - A APREENSÃO COMO MEDIDA SATISFATIVA ………………........ 137

5.1 MedidAS CAUTELARES E MEDIDAS SATISFATIVAS ................................................... 137

5.2 AS COISAS QUE NÃO PODEM SER RESTITUÍDAS ..................................................... 140

5.3 A apreensão satisfativa do artigo 530-B do Código de Processo Penal .. 145

5.3.1 A APREENSÃO PREVISTA NO ARTIGO 530-B DO CPP, O PLS NO 156/2009 E O PL

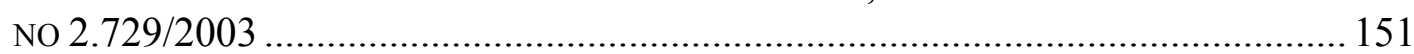

5.3.2 A apreensão prevista no artigo 530-B do Código de Processo Penal e o

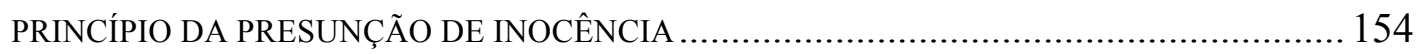

5.3.3 A apreensão prevista no artigo 530-B do Código de Processo Penal: EFICIÊNCIA E GARANTISMO

CONCLUSÕES 164

REFERÊNCIAS 175 


\title{
INTRODUÇÃO
}

\begin{abstract}
A apreensão, como medida cautelar de natureza real, implica retirar de determinada pessoa a coisa por ela possuída, restringindo-lhe o uso e a disposição. Quando a coisa apreendida está diretamente ligada ao crime tem a medida, de regra, finalidades processuais ou penais, objetivando assegurar a produção da prova ou a futura perda do bem em favor da União como efeito da condenação (arts. 119 do CPP e 91, II, letras $a$ e $b$, do CP). ${ }^{1}$
\end{abstract}

Aproveitaram-se para o processo penal os estudos sobre as medidas cautelares no processo civil, como forma de disciplinar que no curso do processo só poderiam existir medidas que fossem destinadas à proteção da marcha processual ou da eficácia e da utilidade do provimento jurisdicional final e que tivessem o escopo nítido e justo de romper com uma tradição de medidas de segurança social incompatíveis com o princípio da presunção de inocência.

Medidas como as prisões processuais decretadas para conter o clamor público ou para dar resposta imediata ao crime por meio do encarceramento antecipado e fundado exclusivamente na gravidade dos crimes cometidos aos poucos foram sendo abolidas das práticas processuais penais brasileiras, restringindo as prisões provisórias aos casos adequados e estritamente necessários. Tramitou por quase uma década o projeto de lei que implantou um sistema de medidas cautelares pessoais de graus distintos para permitir que a prisão processual fosse efetivamente a ultima ratio.

Dentro dessa construção teórica humanista firmou-se o entendimento de que no processo penal apenas as medidas revestidas de cautelaridade seriam lícitas, como forma de respeito ao status de inocência do acusado, vedando quaisquer medidas que revelassem uma antecipação do juízo condenatório. Nesse esteio, a busca e a apreensão passaram a ser entendidas e aceitas apenas como medidas destinadas a assegurar o próprio processo ou o provimento jurisdicional, revelando uma natureza jurídica de meio de obtenção de provas.

Entretanto, com o crescimento vertiginoso das violações de direitos de autor, de autor de software e direitos industriais - decorrentes da globalização econômica e do acesso a mecanismos de cópias até então inexistentes - as indústrias fonográfica, cinematográfica e de software desencadearam uma acirrada campanha de combate aos produtos contrafeitos e uma pressão sobre o Congresso Nacional, com o escopo de

\footnotetext{
FERNANDES, Antonio Scarance. O papel da vítima no processo criminal. São Paulo: Malheiros, 1995.
} 
promover uma reforma da legislação penal para introduzir novos mecanismos de proteção à propriedade imaterial.

Com um discurso de que o dinheiro que circula na pirataria é o mesmo que circula no tráfico ilícito de entorpecentes e no tráfico de armas, as indústrias cinematográfica e de software fomentaram campanhas em todos os meios de comunicação, aliando, ao discurso, dados estatísticos de perda de faturamento e de arrecadação tributária para a União. Com isso, conseguiram promover algumas reformas na legislação brasileira, culminando com a aprovação e a promulgação da Lei no $10.695 / 2003^{2}$.

A referida norma modificou os dispositivos atinentes à matéria no Código Penal ${ }^{3} \mathrm{e}$ criou um novo procedimento especial para os crimes de ação penal de iniciativa pública, determinando que, nesses casos, a medida de apreensão teria o condão de alcançar todos os bens produzidos ou reproduzidos com violação da propriedade imaterial. Essa apreensão de todos os bens ilicitamente produzidos ou reproduzidos deixou de ser aquela apreensão instrumental necessária ao processo, sendo introduzida no sistema com o pretexto de tornar o processo mais efetivo no combate à pirataria.

\title{
Segundo Cândido Rangel Dinamarco, a
}

\begin{abstract}
Efetividade do processo, entendida como se propõe, significa a sua almejada aptidão a eliminar insatisfações, com justiça e fazendo cumprir o direito, além de valer como meio de educação geral para o exercício e respeito aos direitos e canal de participação dos indivíduos nos destinos da sociedade, assegurar-lhes a liberdade. 4
\end{abstract}

Se a efetividade no combate à pirataria se consubstancia na satisfação do direito com justiça (com a corresponde a repercussão positiva do resultado no ambiente social), as mudanças trazidas à disciplina da apreensão pela Lei $\mathrm{n}^{\mathrm{o}} 10.695 / 2003$ devem ser interpretadas observando o equilíbrio entre eficiência e garantismo, pois a título de uma

2 BRASIL. Presidência da República. Casa Civil. Subchefia para Assuntos Jurídicos. Lei $n^{\circ} 10.695$, de $1^{\circ}$ de julho de 2003. Altera e acresce parágrafo ao art. 184 e dá nova redação ao art. 186 do Decreto-Lei no 2.848, de 7 de dezembro de 1940 - Código Penal, alterado pelas Leis nos 6.895, de 17 de dezembro de 1980, e 8.635, de 16 de março de 1993, revoga o art. 185 do Decreto-Lei no 2.848, de 1940, e acrescenta dispositivos ao Decreto-Lei no 3.689, de 3 de outubro de 1941 - Código de Processo Penal. Disponível em: <http://www.planalto.gov.br/ccivil_03/Leis/2003/L10.695.htm>. Acesso em: 28 nov. 2012.

3 BRASIL. Decreto-Lei no 2.848, de 7 de dezembro de 1940. Código Penal. Disponível em: <http://www.planalto.gov.br/ccivil_03/constituicao/constituiçao24.htm>. Acesso em: 15 jul. 2012

4 DINAMARCO, Cândido Rangel. $\bar{A}$ instrumentalidade do processo. 10 ed. São Paulo: Malheiros, 2002. p. 271. 
suposta eficiência dos instrumentos de repressão não se pode criar medidas que importem em justiça sumária ou a qualquer custo.

Segundo o Professor Antonio Scarance Fernandes,

\begin{abstract}
Ante a impossibilidade de se definir com clareza o que configura esse justo equilíbrio e a imensa dificuldade em traduzi-lo nos textos de lei ou na aplicação concreta do direito, a sua busca representa uma meta, uma diretriz, que deve nortear o processo penal, fazendo com que ele, no movimento pendular da história, não se distancie do ponto médio entre a proteção à liberdade e a segurança da sociedade. ${ }^{5}$
\end{abstract}

Assim, a nova medida deixou de ser um instrumento do processo e passou a ter um novo objetivo: dar resposta à sociedade por meio do confisco especial dos bens contrafeitos, antes mesmo da produção da prova pericial apta a demonstrar a contrafação, com características de antecipação de tutela. Logo, o tema suscita uma nova abordagem do instituto da apreensão no ordenamento pátrio e seu exame mostra-se interessante e desafiador.

Por esse motivo escolhemos como título a apreensão no procedimento dos crimes contra a propriedade imaterial, visto que o objeto do presente estudo é a análise das mudanças trazidas ao instituto, seus reflexos e os motivos que provocaram as alterações mencionadas, observando o sistema de proteção penal da propriedade imaterial como um todo.

Com esse propósito, pretendemos verificar se o efeito satisfativo atribuído à apreensão nos procedimentos dos crimes contra a propriedade imaterial de ação de iniciativa privada se justifica no nosso sistema processual penal, em que medida essa modalidade de apreensão viola o princípio da presunção de inocência e, principalmente, se é necessária alguma mudança no procedimento para alcançar o justo equilíbrio entre a eficiência e o garantismo.

Para tal, iniciaremos a presente pesquisa pelo estudo da propriedade intelectual no ordenamento jurídico brasileiro, analisando a origem histórica da proteção dos direitos

FERNANDES, Antonio Scarance. Efetividade, processo penal e dignidade humana. In: MIRANDA, Jorge; SILVA, Marco Antonio Marques da (Coord.). Tratado luso-brasileiro da dignidade humana. 2. ed. São Paulo: Quartier Latin, 2009. p. 528. 
autorais e do direito industrial e ressaltando as modificações mais significativas, com o escopo de identificar os motivos que levam o Estado a conferir direitos de exclusivo aos criadores/inventores. Em seguida, passaremos para a análise do conceito de contrafação, analisando as limitações ao ato de contrafação, a metodologia de apreciação, as espécies de contrafação, atos e imunidades. Ao final desse capítulo inicial, identificaremos qual espécie de contrafação está ligada à ideia de pirataria, identificando o objeto que deve ser perseguido.

No capítulo seguinte, passaremos para a análise da proteção penal da propriedade intelectual, observando que o sistema, concebido em um modelo de escassez de matériaprima e de suportes materiais necessários à reprodução das criações, pautou toda a proteção no controle das cópias e, hoje, com a popularização das tecnologias de produção e reprodução, enfrenta um problema - a pirataria - que atinge tanto os direitos autorais e conexos quanto os direitos industriais.

Partindo dessa premissa, analisaremos as iniciativas tomadas para a modificação do sistema de proteção como forma de defender os interesses das indústrias fonográfica, cinematográfica e de software e as tentativas de associar a pirataria ao crime organizado, com a consequente utilização das medidas assecuratórias de bens da Lei de Lavagem de Dinheiro $^{6}$. Por fim, encerraremos o capítulo com uma breve análise dos tipos previstos, em especial os modificados pela Lei $\mathrm{n}^{\mathrm{o}} 10.695 / 2003$, destacando a falta de sistematização penal da matéria e apresentando as respectivas sugestões de reforma.

No terceiro capítulo, passaremos ao estudo da busca e da apreensão, partindo de um breve histórico dos institutos no ordenamento jurídico brasileiro, seguido da análise dos limites constitucionais das medidas, previstos desde a primeira Constituição brasileira até a Constituição vigente. Em seguida abordaremos as buscas e as apreensões digitais, identificando a insuficiência da regra da inviolabilidade da casa para a proteção da intimidade e da vida privada, para em seguida passarmos a uma breve análise do direito comparado.

6 BRASIL. Lei $n^{\circ}$ 9.613, de 3 de março de 1998. Dispõe sobre os crimes de "lavagem" ou ocultação de bens, direitos e valores; a prevenção da utilização do sistema financeiro para os ilícitos previstos nesta Lei; cria o Conselho de Controle de Atividades Financeiras - COAF, e dá outras providências. Disponível em: <http://www.planalto.gov.br/ccivil_03/leis/L9613.htm>. Acesso em: 28 dez. 2012. 
Estudaremos as buscas e as apreensões no direito processual penal estadunidense, argentino e italiano, destacando que no primeiro se desenvolveu a teoria da expectativa de privacidade, no segundo também foram incorporadas medidas de busca e de apreensão de todos os objetos contrafeitos após a recepção do Acordo Sobre Aspectos dos Direitos de Propriedade Intelectual Relacionados ao Comércio (TRIPs) ${ }^{7}$ e no terceiro já estão disciplinadas as medidas de busca e de apreensão digitais, como resultado da recepção da Convenção sobre o Cibercrime do Conselho da Europa ${ }^{8}$.

No quarto capítulo, passaremos ao estudo da busca e da apreensão como institutos autônomos, destacando os conceitos e a natureza jurídica das medidas, para, em seguida, discorrermos sobre a apreensão no procedimento comum e nos procedimentos especiais dos crimes contra a propriedade imaterial, apontando as diferenças e a natureza jurídica da medida de apreensão introduzida pela Lei no $10.695 / 2003$.

Por fim, no último capítulo, apontaremos o conceito e as características das medidas cautelares e das medidas de antecipação de tutela (satisfativas) e abordaremos a disciplina das coisas que não podem ser restituídas, para, em seguida, apontarmos por que entendemos que a apreensão, no procedimento dos crimes contra a propriedade imaterial de ação de iniciativa pública, tem natureza jurídica satisfativa.

Apontados os motivos que nos levam a entender que a apreensão no procedimento dos crimes contra a propriedade imaterial de ação de iniciativa pública tem natureza jurídica satisfativa, vamos fazer uma breve análise dos projetos de lei existentes sobre a matéria e analisaremos a compatibilidade da medida com o princípio da presunção de inocência, para ao final concluirmos se existe necessidade de modificação do procedimento previsto, em respeito ao equilíbrio entre eficiência e garantismo, como máxima do direito a um procedimento processual penal justo.

7 BRASIL. Acordo Sobre Aspectos dos Direitos de Propriedade Intelectual Relacionados ao Comércio (Acordo TRIPS ou Acordo ADPIC). Brasília, 1994. Disponível em: <http://www.cultura.gov.br/site/wpcontent/uploads/2008/02/ac_trips.pdf>. Acesso em: $24 \mathrm{dez} .2012$.

8 EUROPA. Convention on Cybercrime. Budapeste, 23.XI.2001. Disponível em: $<$ http://conventions.coe.int/Treaty/en/Treaties/Html/185.htm>. Acesso em: 29 ago. 2012. 


\title{
CAPÍTULO I - PROTEÇÃO DA PROPRIEDADE INTELECTUAL
}

\subsection{BREVE HISTÓRICO DA PROTEÇÃO DA PROPRIEDADE INTELECTUAL}

A história acusa como sendo Veneza, em $1474^{9}$, o primeiro lugar do mundo a dispor acerca de proteção de invenção. Depois, em ordem, veio o Estatuto de Monopólios na Inglaterra, em $1623^{10}$; a lei norte-americana de $1790^{11}$; e em quarto lugar a lei francesa de 1791. Naquele período, a propriedade intelectual se justificava como uma forma necessária de restrição à concorrência para que esta pudesse ser efetivamente estimulada por meio do desenvolvimento de novos produtos.

\begin{abstract}
A propriedade intelectual surge originariamente como uma restrição à concorrência, que se considera necessária e adequada para estimular a própria concorrência e assim melhor alcançar os fins da política de inovação e conhecimento, em prol da satisfação do consumidor através de novos e melhores produtos. ${ }^{12}$
\end{abstract}

O Brasil, quando ainda colônia portuguesa, foi o quinto lugar do mundo a instituir um regramento acerca de proteção inventiva, por meio do alvará de 28 de janeiro de $1809^{13}$, concedido pelo príncipe regente. O título do alvará era: "Isenção de direitos às

9 "Ci sono molti uomini in questa città e nelle sue vicinanze, attratti dalla sua eccellenza e magnificenza, molti uomini di diverse origini, con menti ingegnose e in grado di immaginare e scoprire diversi oggetti artificiosi. E se fosse possibile garantire loro l'onore che altri uomini non si impossessino dei loro artifici, allora questi uomini userebbero le loro menti per scoprire cose di non poca utilità per la nostra repubblica. Chiunque creerà nella nostra Venezia un nuovo ingegnoso artificio, non creato da nessun altro in precedenza, sarà obbligato a registrarlo negli uffici comunali. Non sarà possibile a nessun altro uomo della nostra repubblica creare un oggetto a immagine e somiglianza di quello, senza il permesso dell'inventore, per un periodo di dieci anni." (DINI, Roberto. Le origini della proprietà intellettuale. In: Proprietà intellettuale. Uno strumento per la crescita economica nel terzo millennio. Roma: LES Italia, p. 7-17, 2010. p. 8.

10 Reino Unido. Statute of Monopolies 1623. Disponível em: <http://www.legislation.gov.uk/aep/Ja1/21/3>. Acesso em: 27 nov. 2012.

11 E.U.A. Copyright Act of 1790. Disponível em: <http://www.copyright.gov/history/1790act.pdf>. Acesso em: 27 nov. 2012.

12 PEREIRA, Alexandre Libório Dias. Inovação tecnológica, propriedade intelectual e defesa da concorrência no mercado de software. Boletim da Faculdade de Direito da Universidade de Coimbra, Coimbra, v. 85, p. 237-259, 2009. p. 237.

13 "VI - Sendo muito conveniente que os inventores e introdutores de alguma nova máquina e invenção nas artes gozem do privilégio exclusivo, além do direito que possam ter ao favor pecuniário, que sou servido estabelecer em benefício da indústria e das artes, ordeno que todas as pessoas que estiverem neste caso apresentem o plano de seu novo invento à Real Junta do Comércio; e que esta, reconhecendo-lhe a verdade e fundamento dele, lhes conceda o privilégio exclusivo por quatorze anos, ficando obrigadas a fabricá-lo depois, para que, no fim desse prazo, toda a Nação goze do fruto dessa invenção. Ordeno, outrossim, que se faça uma exata revisão dos que se acham atualmente concedidos, fazendo-se público na forma acima determinada e revogando-se todas as que por falsa alegação ou sem bem fundadas razões obtiveram semelhantes concessões". (BRASIL. Alvará de 28 de abril de 1.809. Isenta de direitos as matérias primas do uso das fábricas e concede outros favores aos fabricantes e da navegação nacional. $<$ http://www.tecpar.br/appi/legislacao/conteudo/alvarah.htm>. Acesso em: 28 dez. 2012). 
matérias primas do uso das fábricas e concessão de outros favores aos fabricantes e da navegação".

Tal regramento não decorreu de um avançado processo de industrialização do nosso país, muito pelo contrário, a política da Coroa portuguesa era exatamente oposta, proibindo toda e qualquer atividade que pudesse desviar a exploração extrativista das riquezas naturais da colônia. Durante o século XVIII, a produção da colônia restringia-se à mineração, à lavoura e às indústrias extrativistas naturais ${ }^{14}$.

\begin{abstract}
Na última metade do século XVIII, já se contavam, nos centros mais adiantados, muitas manufaturas autônomas, relativamente grandes, organizadas comercialmente, que revelavam o espírito de iniciativa dos habitantes da colônia. Não tardaria, porém, que a metrópole tomasse medidas adequadas para impedir o progresso industrial que timidamente se esboçava. [...] o Alvará de 5 de janeiro de $1785^{[15]}$, que mandou extinguir todas as fábricas e manufaturas existente na colônia, a fim de que não fossem prejudicadas a agricultura e a mineração. ${ }^{16}$
\end{abstract}

Se o objetivo da Coroa até o fim do século XVIII era impedir o desenvolvimento industrial do Brasil para evitar a independência desse país em relação a Portugal e manter as atividades econômicas concentradas naquelas de interesse da metrópole, significativas mudanças foram realizadas com a transferência da sede do trono português para a colônia.

A primeira delas foi a abertura dos portos às nações amigas em 28 de janeiro de 1808, que aboliu as vedações absolutas de acesso ao mercado brasileiro, impondo uma tarifa geral de $24 \%$ às mercadorias estrangeiras ${ }^{17}$. Em seguida, o alvará de $1^{\circ}$ de abril de

14 Cf. CERQUEIRA, João da Gama. Tratado da propriedade industrial. Rio de Janeiro: Lumen Juris, 2010a. v. 1.p. 1.

15 O próprio texto do Alvará demonstra a preocupação em impedir a atividade: “[...] Que sendo-me presente o grande número de Fabricas, e Manufacturas, que de alguns annos a esta parte se tem diffundido em differentes Capitanías do Brazil, com grave prejuizo da Cultura, e da Lavoura, e da exploração de Terras Mineraes daquelle vasto Continente; porque havendo nelle huma grande, e conhecida falta de População, he evidente, que quanto mais se multiplicar o número dos Fabricantes, mais diminuirá o dos Cultivadores; e menos Braços haverá, que se possão empregar no descubrimento, e rompimento de huma grande parte daquelles extensos Domínios, que ainda se acha inculta, e desconhecida:" (PORTUGAL. Anno de 1795. Disponível em: $<$ http://www.iuslusitaniae.fcsh.unl.pt/verlivro.php?id_parte=109\&id_obra=73\&pagina=565 $>$. Acesso em: 27 nov. 2012)

${ }^{16}$ CERQUEIRA, João da Gama, 2010a, p. 2.

17 Cf. BARBOSA, Denis Borges. Tratado da propriedade intelectual. Rio de Janeiro: Lumen Juris, 2010. tomo 1. p. 11. 
$1808^{18}$ revogou o alvará de 1875 , libertando as manufaturas de todas as restrições anteriormente impostas.

"Estabelecida a liberdade de indústria, fazia-se mister, entretanto, amparar as que se criassem, permitindo-lhes concorrer com os produtos estrangeiros, cuja importação na colônia se tornara livre de empecilhos." ${ }^{19}$. No esteio dessas medidas de criação de um ambiente minimamente fértil para o desenvolvimento de uma indústria nacional, cessando o privilégio manufatureiro português, foi promulgado o Alvará de 28 de janeiro de 1809 , que criou o primeiro sistema de patentes de invenção para as indústrias estabelecidas no Brasil.

Em resumo, a norma jurídica instituída pelo príncipe regente determinava que o autor de qualquer invenção de nova máquina ou artes usufruísse de privilégio pecuniário. Tal privilégio seria concedido após apreciação da Real Junta do Comércio, que analisava o invento e concedia o privilégio exclusivo pelo prazo de 14 anos, ficando o autor da invenção obrigado a publicá-la, para que a nação pudesse usufruir dela.

O mesmo alvará determinava que fossem revistas todas as concessões de privilégio já existentes e revogadas aquelas em que se verificasse falsa alegação ou ausência de razão fundada. "Por este alvará verifica-se que, antes de 1809, já existiam no Brasil privilégios e monopólios, mas concedidos por mercê do governo real, como era comum na época, sistema que prevaleceu em Portugal até princípios do século XIX."20

Ainda que extremamente primitiva, a regra instituída sobre propriedade intelectual tornava o Brasil um país quase pioneiro, haja vista que noutros países, com um

18 "Eu o Principe Regente faço saber aos que o presente Alvará virem: que desejando promover e adiantar a riqueza nacional, e sendo um dos mananciaes della as manufacturas e a industria que multiplicam e melhoram e dão mais valor aos generos e productos da agricultura e das artes e augmentam a população dando que fazer a muitos braços e fornecendo meios de subsistencia a muitos dos meus vassallos, que por falta delles se entregariam aos vicios da ociosidade: e convindo remover todos os obstaculos que podem inutilisar e frustrar tão vantajosos proveitos: sou servido abolir e revogar toda e qualquer prohibição que haja a este respeito no Estado do Brazil e nos meus Dominios Ultramarinos e ordenar que daqui em diante seja licito a qualquer dos meus vassallos, qualquer que seja o Paiz em que habitem, estabelecer todo o genero de manufacturas, sem exceptuar alguma, fazendo os seus trabalhos em pequeno, ou em grande, como entenderem que mais lhes convem; para o que hei por bem derogar o Alvará de 5 de Janeiro de 1785 e quaesquer Leis ou Ordens que o contrario decidam, como se dellas fizesse expressa e individual menção, sem embargo da Lei em contrario." (BRASIL. Alvará de $1^{\circ}$ de abril de 1808. Coleç̧ão das Leis do Brazil de 1808. Rio de Janeiro: Imprensa Nacional, 1891. p. 10.).

19 CERQUEIRA, João da Gama, 2010a, p. 3.

20 CERQUEIRA, João da Gama, 2010a, p. 4. 
desenvolvimento industrial muito superior ao brasileiro, não existia tal apontamento. Posteriormente, a propriedade intelectual foi reconhecida como direito na Constituição do Império de $1824^{21}$.

Em 28 de agosto $1830^{22}$ o imperador, D. Pedro I, promulgou a primeira lei específica acerca da propriedade intelectual, estabelecendo a proteção às patentes de invenção prevista no ordenamento anterior e acrescentando, em seu artigo $2^{\circ}$, a previsão de proteção aos aperfeiçoamentos das invenções ${ }^{23}$.

Cumpre aqui observar que a violação dos direitos assegurados pelo privilégio era reprimida com pena de multa, ressarcimento de danos e perda dos produtos e dos instrumentos utilizados na fabricação, na forma do artigo $7^{\circ}$ da referida lei, sem a previsão de qualquer sanção penal para a contrafação.

Em 1875, pelo Decreto $\mathrm{n}^{\mathrm{o}} 2.682^{24}$, surgiu o direito de marcar o produto de manufatura e comércio por meio de sinais distintivos do fabricante. Remonta à história de que a mola propulsora da referida norma foi o desfecho da ação criminal intentada pelos industriais Meuron \& Cia, representados por Rui Barbosa, contra a empresa Moreira \& Cia.

O litígio girou em torno da contrafação da marca Rapé Areia Preta, imitada pela marca Rapé Areia Parda. Condenados em primeira instância, os contrafatores (Moreira \& Cia) foram absolvidos pelo Tribunal da Relação da Bahia por atipicidade da conduta, uma

21 BRASIL. Constituicão Politica do Imperio do Brazil (de 25 de março de 1824). Disponível em: $<$ http://www.planalto.gov.br/ccivil_03/constituicao/constitui\%C3\%A7ao24.htm>. Acesso em: 29 nov. 2012.

22 Além da proteção da propriedade intelectual, a lei de 28 de agosto de 1830 estabelecia um prêmio para as indústrias estrangeiras implantadas no país, haja vista a dificuldade e a utilidade dessa introdução. (BRASIL. Lei de 28 de agosto de 1830. Concede privilégio ao que descobrir, inventar ou melhorar uma industria util e um premio ao que introduzir uma industria estrangeira, e regula sua concessão. Disponível em: <http://www2.camara.leg.br/legin/fed/lei_sn/1824-1899/lei-37976-28-agosto-1830-565630-normapl.html>. Acesso em: 29 nov. 2012).

23 "No tempo do império as patentes de invenção eram concedidas por decreto do Poder Executivo e constavam de uma carta assinada pelo Imperador, referendada pelo ministro da Agricultura, Comércio e Obras Públicas e selada com o selo pendente das armas do Império.” (CERQUEIRA, João da Gama. 2010a, p. 140).

24 BRASIL. Decreto $n^{\circ}$ 2.682, de 23 de outubro de 1875. Regula o direito que têm o fabricante e o negociante, de marcar os productos de sua manufactura e de seu commercio. Disponível em: $<$ http://www2.camara.leg.br/legin/fed/decret/1824-1899/decreto-2682-23-outubro-1875-549770publicacaooriginal-65288-pl.html>. Acesso em: 29 nov. 2012. 
vez que não havia, no Código Criminal do Império $^{25}$, norma que vedasse a imitação de marca.

Os empresários da Meuron \& Cia dirigiram uma representação, juntamente com outros empresários interessados, à Comissão de Justiça Criminal da Câmara dos Deputados, desencadeando o processo legislativo que deu origem ao Decreto $n^{0} 2.682$, de 23 de outubro de 1875, que passou a tutelar a propriedade das marcas e o respectivo registro.

Daí por diante, foram instituídas diversas normas regulamentando o tema da propriedade industrial, dentre as quais podemos destacar:

a) O Decreto $\mathrm{n}^{\mathrm{o}} 24.507$, de 29 de junho de $1934^{26}$, que inovou ao estabelecer a proteção tanto dos privilégios aos desenhos e aos modelos industriais quanto do registro do nome comercial e do título de estabelecimento;

b) O Decreto $n^{\text {o }} 7.903$, de 27 de agosto de $1945^{27}$, que revogou todo o regramento anterior e inovou ao instituir a proteção de modelos de utilidade, de desenhos ou modelos industriais, de variedades novas de plantas e a repressão à concorrência desleal. Também revogou dispositivos do Código Penal, estabelecendo norma especial a respeito do tema, permitiu a destruição de marca falsificada, e disciplinou pela primeira vez procedimento especial para os crimes contra a propriedade industrial;

c) O Decreto-Lei $n^{\circ} 254$, de 28 de fevereiro de $1967^{28}$, o qual inovou ao prever proteção às marcas notoriamente conhecidas;

25 Cf. BARBOSA, Denis Borges, 2010, p. 22.

26 BRASIL. Decreto n. 24.507 de 29 de junho de 1934. Approva o regulamento para a concessão de patentes de desenho ou modelo industrial, para o registro do nome commercial e do titulo de estabelecimentos e para a repressão á concorrencia desleal, e dá outras providencias. Disponível em: <http://www6.senado.gov.br/legislacao/ListaPublicacoes.action?id=28412>. Acesso em: 27 nov. 2012.

27 BRASIL. Decreto-lei $n^{\circ} 7.903$ de 27 de agosto de 1945. Código da Propriedade Industrial. Disponível em: <http://www.planalto.gov.br/ccivil_03/decreto-lei/1937-1946/Del7903.htm>. Acesso em 27 nov. 2012.

28 BRASIL. Decreto-Lei $n^{\circ} 254$, de 28 de fevereiro de 1967. Código da Propriedade Industrial. Disponível em: <http:/www2.camara.leg.br/legin/fed/declei/1960-1969/decreto-lei-254-28-fevereiro-1967-374675publicacaooriginal-1-pe.html>. Acesso em: 27 nov. 2012. 
d) A Lei $n^{\text {o }} 5.648$, de 11 de dezembro de $1970^{29}$, que criou o Instituto Nacional da Propriedade Industrial (INPI), autarquia federal com finalidade essencial de executar em todo o país as normas que regulamentam a propriedade industrial.

e) A Lei $n^{\circ} 5.772$, de 21 de dezembro de $1971^{30}$, que foi um marco para a propriedade industrial, com a criação da Revista da Propriedade Industrial, que passou a fazer o papel do Diário Oficial da União, em matéria de propriedade industrial. Trouxe também para o sistema a Classificação Internacional de Patentes.

f) A Lei $n^{\text {o }} 9.279$, de 14 de maio de $1996^{31}$, conhecida como a Nova Lei de Propriedade Industrial, que revogou o Código da Propriedade Industrial, a Lei $\mathrm{n}^{\circ}$ 6.348/1976, os artigos 187 a 196 do Código Penal e os artigos 169 e 189 do Decreto $\mathrm{n}^{\mathrm{o}} 7.903 / 1945$ modificou integralmente a proteção penal da propriedade industrial.

O direito autoral, por sua vez, teve origem completamente distinta da origem da propriedade industrial.

Na antiguidade, já existia a noção de plágio, entretanto a dificuldade de realizar o processo de reprodução dos originais exercia um forte controle da divulgação das ideias, limitada ao trabalho manual dos copistas.

\footnotetext{
Com a invenção da imprensa, os soberanos sentiam-se ameaçados com a iminente democratização da informação e criaram um ardiloso instrumento de censura, consistente em conceder aos donos dos meios de produção dos livros o monopólio da comercialização dos títulos que editassem, a fim de que estes, em contrapartida, velassem para que o conteúdo não fosse desfavorável à ordem vigente. $^{32}$
}

29 BRASIL. Lei $n^{\circ} 5.648$, de 11 de dezembro de 1970. Cria o Instituto Nacional da Propriedade Industrial e dá outras providências. Disponível em: <http://www.planalto.gov.br/ccivil_03/leis/L5648.htm>. Acesso em: 27 nov. 2012

30 BRASIL. Lei $n^{\circ}$ 5.772, de 21 de dezembro de 1971. Institui o Código da Propriedade Industrial, e dá outras providências. Disponível em: $<$ http://www.planalto.gov.br/ccivil_03/leis/L5772.htm>. Acesso: em 27 nov. 2012.

31 BRASIL. Lei $n^{\circ}$ 9.279, de 14 de maio de 1996. Regula direitos e obrigações relativos à propriedade industrial. Disponível em: <http://www.planalto.gov.br/ccivil_03/leis/L9279.htm>. Acesso em 27 nov. 2012.

32 VIANNA, Túlio Lima. A ideologia da propriedade intelectual: a inconstitucionalidade da tutela penal dos direitos patrimoniais do autor. Revista Síntese de Direito Penal e Processual Penal, Porto Alegre, v. 6, n. 33, p. 7-22, ago./set. 2005. p. 8. 
Com esse propósito, o direito de exclusivo no controle da reprodução dos escritos passou a ser denominado "copyright", que não nasceu da proteção dos autores, e sim da proteção dos livreiros, que passam a ter assegurada a exclusividade na reprodução da obra em contrapartida ao controle do conteúdo e à censura. A própria etimologia do termo já demonstra que a proteção era destinada ao direito de cópia, e não aos direitos morais e patrimoniais do autor ${ }^{33}$.

Entretanto, apesar de ser criado como um mecanismo de controle, “[...] a pioneira Lei da Rainha Ana de Inglaterra (1710) o copyright foi justificado como instrumento de 'encorajamento da aprendizagem'., 34 .

Esse mecanismo de controle também foi adotado pela Coroa portuguesa, que proibiu qualquer impressão de livros no Brasil, estabelecendo o monopólio de impressão pela imprensa do governo e a censura prévia às publicações.

Em 1747 foram publicadas no Brasil duas obras referentes ao bispo Antonio do Desterro Malheyro. Entretanto, ao tomar conhecimento da atividade de tipografia exercida por Antonio Isidoro da Fonseca, a Coroa determinou o fechamento do negócio do tipógrafo, visto que a impressão na colônia não era conveniente aos interesses da Coroa.

Em 1750, Antonio Isidoro da Fonseca, que tinha sido expulso do Brasil, voltou a solicitar licença real para instalar novamente seu tipógrafo no Rio de Janeiro e em Salvador $^{35}$, contudo, apesar de se comprometer a não mais imprimir sem as licenças civis e eclesiásticas, teve sua licença negada com despacho no próprio pedido ("Excusado") 36 .

Uma vez que a impressão no Brasil era proibida pela Coroa portuguesa, toda a atividade literária brasileira era impressa e publicada na Europa, ou permanecia na forma

\footnotetext{
33 "A natureza do trabalho intelectual, que poderia ser replicado ad infinitum, acabou por ser tomada como 'propriedade intelectual', mesmo contra todas as evidências de que, uma vez alienada, a propriedade não pode mais ser utilizada por quem um dia a possuiu. Firmou-se, então, a ideologia da "propriedade intelectual', ocultando a venda do trabalho intelectual aos detentores dos meios de produção." VIANNA, Túlio Lima, 2005, p. 11.

34 PEREIRA, Alexandre Libório Dias, 2009, p. 240.

35 Cf. HALLEWELL, Laurence. O livro no brasil: sua história. 2. ed. São Paulo: Edusp, 2005, p. 95.

36 Cf. MORAES, Rubens Borba de. O bibliófilo aprendiz. 4. ed. Rio de Janeiro: Casa da Palavra, 2005, p. 154-158.
} 
manuscrita. Dentre os autores que publicaram em Portugal, podemos destacar José Basílio da Gama, José de Santa Rita Durão, Cláudio Manoel da Costa e Tomás Antônio Gonzaga.

O Correio Braziliense, editado por Hipólito José da Costa, era impresso na Inglaterra; já em Paris, se desenvolveu um comércio editorial de obras em língua portuguesa que se estendeu até $1930^{37}$.

Até a transferência da família real portuguesa para o Brasil, em 1808, existiam apenas duas livrarias no Rio de Janeiro, e os livros disponíveis, em sua grande maioria, eram contrabandeados. Junto com a família real, vieram para o Brasil 60 mil volumes da Biblioteca Real, formando o primeiro acervo da atual Biblioteca Nacional, que foi criada em 1810 sob a denominação de "Biblioteca Real"38.

A Imprensa Régia foi instalada no Brasil em 13 de maio de 1808, por decreto de D. João VI, quando foi publicado um folheto de 27 páginas, acompanhado da Carta Régia ${ }^{39}$. O monopólio da impressão pela Imprensa Régia perdurou no Brasil até 1822, quando foi promulgada a nova Constituição portuguesa ${ }^{40}$, que aboliu a censura prévia e o monopólio da imprensa oficial.

O primeiro regramento digno de destaque foi a recepção da Convenção da União de Paris, promulgada pelo Brasil em 28 de junho de 1884 pelo Decreto $n^{0} 9.233^{41}$. A Convenção da União de Paris foi precedida de diversas reclamações de Portugal contra o Brasil, que publicava, sem a autorização das editoras e dos autores, cópias das obras literárias portuguesas.

37 Cf. HALLEWELL, Laurence. 2005, p. 108-109.

38 Cf. PREITE SOBRINHO, Wanderley. Acervo da família real portuguesa contribui para criação da Biblioteca Nacional. Folha Online, São Paulo, 3 mar. 2008. Disponível em: $<$ http://www1.folha.uol.com.br/folha/ brasil/ult96u374639.shtml>. Acesso em: 15 jul. 2012.

39 Cf. MORAES, Rubens Borba de. A impressão régia do Rio de Janeiro: origens e produção. In: CAMARGO, Ana Maria de Almeida. Bibliografia da impressão régia do Rio de Janeiro. São Paulo: Edusp, 1993. p. 17-31. p. 18.

40 Portugal. Constituição portuguesa de 1822. Dedicada à Excelsa Soberania das Cortes Lusitanas. Disponível em: <http://www.arqnet.pt/portal/portugal/liberalismo/const822.html>. Acesso em: $28 \mathrm{dez}$. 2012.

41 BRASIL. Decreto $n^{\circ}$ 9.233, de 28 de junho de 1884. Promulga a convenção, assignada em Pariz a 20 de março de 1883, pela qual o Brazil e outros Estados se constituem em União para a protecção da propriedade industrial. Disponível em: <http://www2.camara.leg.br/legin/fed/decret/1824-1899/decreto9233-28-junho-1884-543834-publicacaooriginal-54426-pe.html>. Acesso em: 28 dez. 2012. 
Posteriormente, o destaque é do Código Civil de $1916^{42}$, nos artigos 649 a 673 e 1346 a 1362 , e das Leis $n^{\circ} 4.944 / 1966^{43}$ e 5.988/1973 ${ }^{44}$. Em verdade, o sistema de direitos autorais era regido por todos esses dispositivos, pois algumas das disposições do Código Civil não haviam sido revogadas por essas duas leis posteriores.

Atualmente, os direitos autorais estão regulados pela Lei $n^{\circ} 9.610 / 1998^{45}$, que unificou o tratamento legal do tema, tendo sido revogadas todas as disposições anteriores, exceto os parágrafos $1^{\circ}$ e $2^{\circ}$ do artigo 17 da Lei $n^{\circ} 5.998 / 1973$, que dispõe acerca do registro da obra ${ }^{46}$.

\begin{abstract}
Com poucas exceções, mantém-se na nova lei e se acentua o espírito nitidamente empresarial da lei de direitos autorais anterior, de $\mathrm{n}^{\circ} 5.988$, de 1973. A nova lei é uma reescrita da lei anterior, com acréscimos, algumas correções e a supressão do intervencionismo na arrecadação dos direitos autorais. Parece ter sido montada, como uma transparência, sobre a lei ora revogada. Os acréscimos se devem aos desafios do desenvolvimento tecnológico: os programas de computador, os bancos de dados e as transmissões e o armazenamento por meios eletrônicos. ${ }^{47}$
\end{abstract}

\title{
1.2 CONCEITO DE PROPRIEDADE INTELECTUAL
}

A propriedade intelectual é um ramo do direito que tutela direitos reais sobre bens incorpóreos ou imateriais, que, apesar de sua natureza imaterial, são absolutos, no sentido de serem oponíveis erga omnes ${ }^{48}$. O direito de uso, fruição e disposição é exercido, pelos

42 BRASIL. Lei $n^{\circ} 3.071$, de $1^{\circ}$ de janeiro de 1916. Código Civil dos Estados Unidos do Brasil. Disponível em: <http://www.planalto.gov.br/ccivil_03/leis/L3071.htm>. Acesso em: 28 dez. 2012.

43 BRASIL. Lei no 4.944, de 6 de abril de 1966. Dispõe sôbre a proteção a artistas, produtores de fonogramas e organismos de radiodifusão, e dá outras providências. Disponível em: $<$ https://www.planalto.gov.br/ccivil_03/leis/1950-1969/14944.htm>. Acesso em: 28 dez. 2012.

44 BRASIL. Lei $n^{\circ}$ 5.988, de 14 dezembro de 1973. Regula os direitos autorais e dá outras providências. Disponível em: <http://www.planalto.gov.br/ccivil_03/leis/L5988.htm>. Acesso em: 28 dez. 2012.

45 BRASIL. Lei $n^{\circ}$ 9.610, de 19 de fevereiro de 1998. Altera, atualiza e consolida a legislação sobre direitos autorais e dá outras providências. Disponível em: <http://www.planalto.gov.br/ccivil_03/leis/ L9610.htm>. Acesso em: 27 nov. 2012.

46 "Provisoriamente, manteve em vigor o artigo 17 da lei anterior, a qual delega a diversos órgãos ou instituições o registro por categoria ou espécie, com prejuízos incalculáveis ao direito autoral no Brasil." (SILVEIRA, Newton. Comentários a nova lei de direito autoral n. 9.610 de 19 de fevereiro de 1998. Revista da ABPI, Rio de Janeiro, n. 31, p. 35-40, 1997. p. 37).

47 SILVEIRA, Newton, 1997, p. 35.

48 "A propriedade intelectual confere direitos exclusivos oponíveis erga omnes, i.e. contra todos os que explorem economicamente os bens protegidos independentemente do sector de mercado." (PEREIRA, Alexandre Libório Dias, 2009, p. 241). 
proprietários, diretamente sobre esses bens e indiretamente sobre terceiros, que são obrigados a respeitar a relação jurídica entre proprietário e objeto da propriedade ${ }^{49}$.

\begin{abstract}
A Convenção da OMPI [Organização Mundial da Propriedade Intelectual] define como Propriedade Intelectual, a soma dos direitos relativos às obras literárias, artísticas e científicas, às interpretações, dos artistas intérpretes e às execuções dos artistas executantes, aos fonogramas e às emissões de radiodifusão, às invenções em todos os domínios da atividade humana, às descobertas científicas, aos desenhos e modelos industriais, às marcas industriais, comerciantes e de serviço, bem como às firmas comerciais e denominações comerciais, à proteção contra a concorrência desleal e todos os outros direitos inerentes à atividade intelectual nos domínios industrial, científico, literário e artístico. ${ }^{50}$
\end{abstract}

Partindo dessa definição, podemos dividir a propriedade intelectual em duas categorias principais, sendo a primeira a das criações, pertencentes ao respectivo criador, e a segunda a dos sinais distintivos, que pertencem às empresas.

As criações se subdividem em direitos de autor, programas de computador, cultivares e criações industriais. Já os sinais distintivos se subdividem em nome empresarial e marcas.

\title{
1.2.1 DiREITOS AUTORAIS
}

Os direitos autorais, tutelados pela Lei $\mathrm{n}^{\mathrm{o}}$ 9.610/1998, mantêm um sistema unitário de tratamento do direito de autor e dos direitos conexos, designados como "direitos autorais", abrangendo os direitos sobre as obras literárias, artísticas e científicas, os direitos dos artistas intérpretes e executantes e os direitos industriais dos produtores de fonogramas e videogramas e das empresas de radiodifusão ${ }^{51}$.

Apesar de variados, são protegidos por esses direitos as conferências, as locuções, os sermões e outras obras da mesma natureza; as obras dramáticas e dramático-musicais; as obras coreográficas e pantonímicas; as composições musicais, tenham ou não letra; as obras audiovisuais, sonorizadas ou não, inclusive as cinematográficas; as obras fotográficas e de processo análogo à fotografia; as obras de desenho, pintura, gravura,

49 Cf. SILVEIRA, Newton. Propriedade intelectual. 4. ed. rev. e ampl. Barueri: Manole, 2011. p. 83.

50 BARBOSA, Denis Borges, 2010, p. 7.

51 Cf. SILVEIRA, Newton, 2011, p. 55. 
escultura, litografia e arte cinética; e muitas outras espécies de criações de espírito, expressas por qualquer meio ou fixadas em qualquer suporte.

Os programas de computador (softwares) também se incluem na proteção autoral, porém são objeto da proteção especial da Lei n ${ }^{0}$ 9.609/1998. Eles não foram especificados como propriedade industrial, o que lhes atribuiria maior rigor ante o direito, em razão da proteção preventiva mais eficaz dada pela legislação dos direitos do autor, que assegura a proteção para a obra ainda não registrada ${ }^{52}$.

No Brasil, os órgãos responsáveis pelo registro das chamadas "obras literárias, artísticas e científicas" são: Biblioteca Nacional; Escola de Música da Universidade Federal do Rio de Janeiro; Escola de Belas Artes da Universidade Federal do Rio de Janeiro; Agência Nacional do Cinema (Ancine); Conselho Federal de Engenharia e Agronomia $^{53}$.

Apesar da existência dos órgãos de registro, a proteção dada pelo ordenamento jurídico brasileiro ao direito autoral independe de registro prévio, bastando a devida comprovação da qualidade de autor.

Por fim, cumpre ressaltar que os direitos patrimoniais de autor são temporalmente limitados, como regra geral, a 70 anos, contados de $1^{\circ}$ de janeiro do ano subsequente ao do falecimento do autor. Caso este não tenha deixado sucessores, a obra cai em domínio público na data do seu falecimento. Para as obras anônimas ou pseudônimas e para as obras audiovisuais ou fotográficas, os 70 anos são contados a partir de $1^{\circ}$ de janeiro do ano subsequente à sua primeira publicação e divulgação, respectivamente ${ }^{54}$.

52 "Discutiu-se muito a criminalização relativa aos programas de computador uma vez que na doutrina não havia consenso quanto a saber se a noção de obra literária e artística os abrangia para efeitos de protecção pelo direito de autor, sabendo-se que a protecção pelo direito das patentes tinha sido negada pela Convenção de Munique." (PEREIRA, Alexandre Libório Dias. Propriedade intelectual, concorrência desleal e sua tutela (penal) em Portugal. Revista da Associação Brasileira de Propriedade Intelectual, Rio de Janeiro, n. 56, p. 15-34, 2002. p. 28.).

53 Com a criação do Conselho de Arquitetura e Urbanismo do Brasil pela Lei n ${ }^{0} 12.378 / 2010$, o Conselho Federal de Engenharia, Arquitetura e Agronomia passou a ser denominado "Conselho Federal de Engenharia e Agronomia".

54 Cf. SILVEIRA, Newton, 1997, p. 38. 


\subsubsection{PROPRIEDADE INDUSTRIAL}

A propriedade industrial trata principalmente da proteção de patentes (invenções e modelos de utilidade), desenhos industriais e marcas e da repressão da concorrência desleal. Invenções, marcas e desenhos industriais têm características em comum, na medida em que essa proteção é assegurada sob a forma de direitos exclusivos de exploração.

Diversamente da visão romântica ainda presente no direito autoral, o direito industrial protege principalmente os aspectos patrimoniais da propriedade intelectual. "La visión romántica que pone al sacrificado inventor como el destinatario de la protección, se desvanece tan pronto se consultan las disposiciones referidas a las invenciones realizadas durante una relación de trabajo." 55

Apesar de a proteção da propriedade industrial ser essencialmente patrimonial, e não voltada para os direitos morais do autor, a razão da concessão dos direitos de exclusivo pelo Estado permanece fundada na ideia de difundir o conhecimento, por meio da divulgação das invenções, as quais, com o decurso do prazo previsto no título, cairão em domínio público.

Por meio desse mecanismo, o Estado retribui ao criador os investimentos despendidos com pesquisa e desenvolvimento de novos produtos, permitindo que ele dilua esses altos custos no tempo de produção como exclusivo.

Para tanto, aquele que deposita um pedido de patente de invenção ou de modelo de utilidade, bem como aquele que deposita um pedido de registro de desenho industrial, deve divulgar suas invenções, revelando os segredos industriais e preenchendo os requisitos legais que comprovem: 1) a novidade da criação, que não deve fazer parte do estado da técnica no momento do depósito; 2) a existência de atividade inventiva; e 3) a respectiva aplicação industrial do objeto do pedido de patente ${ }^{56}$.

55 LACKNER, Ricardo. Aspectos penales de la ley de patentes n. 17.164. Revista de Derecho Penal, Montevideo, v. 13, p. 439-456, 2002. p. 451.

${ }^{56}$ Os artigos $8^{\circ}$ e $9^{\circ}$ da Lei $n^{\circ}$ 9.279/1996 estabelecem que são patenteáveis: a invenção que atenda aos requisitos de novidade, atividade inventiva e aplicação industrial; e, como modelo de utilidade, o objeto 
A partir da divulgação das invenções, é permitido a outros particulares produzir o objeto da invenção mediante licenciamentos, bem como a outros inventores criar aperfeiçoamentos sobre a invenção original, que podem ser objeto de pedidos de patente de aperfeiçoamento $^{57}$, sem caracterizar a contrafação.

Podemos, então, definir as patentes como títulos de propriedade temporária sobre uma invenção ou um modelo de utilidade, outorgados pelo Estado a inventores, autores ou outras pessoas físicas ou jurídicas detentoras de direitos sobre a criação. Como contrapartida da concessão de tais títulos de propriedade, o depositante deve comprovar o preenchimento dos requisitos legais, se obrigando a revelar detalhadamente, no pedido de patente, todo o conteúdo técnico relacionado às exigências protegidas pela patente ${ }^{58}$.

Apesar de ter outros requisitos para o depósito e de estar sujeito apenas a registro ${ }^{59}$, podemos conceituar o desenho industrial como a forma plástica ornamental de um objeto ou o conjunto ornamental de linhas e cores que possa ser aplicado a um produto, proporcionando resultado visual novo e original na sua configuração externa e podendo servir de tipo de fabricação industrial.

As marcas, segundo a legislação brasileira, são todos os sinais distintivos visualmente perceptíveis que identificam e distinguem produtos e serviços, certificam a conformidade destes com determinadas normas ou especificações técnicas e os distinguem de outros análogos, de procedência diversa ${ }^{60}$.

Por esse motivo, as marcas não estão sujeitas aos prazos estabelecidos para os direitos de exclusivo previstos para as patentes de invenção ou modelos de utilidade e para

de uso prático, ou parte dele, suscetível de aplicação industrial, que apresente nova forma ou disposição, envolvendo ato inventivo que resulte em melhoria funcional no seu uso ou em sua fabricação.

57 A Lei $n^{\circ} 9.279 / 1996$ obriga os titulares das patentes de invenção ou modelo de utilidade a conceder licenças facultativas ou compulsórias aos criadores de invenções ou modelos de utilidade que aperfeiçoam as invenções ou modelos de utilidade originais, permitindo, assim, o avanço do conhecimento científico e do estado da técnica.

58 Cf. CERQUEIRA, João da Gama. Tratado da propriedade industrial. Rio de Janeiro: Lumen Juris, 2010b. v. 2, tomo 1. p. 33.

59 Por não envolver atividade inventiva, os desenhos industriais não são objeto de patente. No caso desses itens, são analisadas apenas a novidade, a originalidade e a possibilidade de aplicação como tipo de fabricação industrial, cuja proteção se inicia com o respectivo registro no INPI, na forma dos artigos 94 e seguintes da Lei $n^{\circ}$ 9.279/1996.

60 Cf. SILVEIRA, Newton, 1997, p. 15. 
os registros de desenhos industriais, já que se caracterizam como a identificação de procedência e conformidade, e razão pela qual não podem ser colocadas em domínio público.

Sendo assim, tanto o direito de autor quanto os direitos de propriedade industrial conferem um direito disponível de gozo exclusivo temporário a seus titulares, “[...] todavia, enquanto no direito de autor a proteção é concedida pelo mero facto da criação, na propriedade industrial são exigidas certas formalidades (depósito ou registro) [...]",61, que são a forma utilizada para controlar o preenchimento dos requisitos necessário à concessão do direito de exclusivo.

Entretanto, uma vez que os referidos títulos de propriedade imaterial são concedidos dentro do território nacional, foi necessária a harmonização internacional das regras de propriedade intelectual, por meio de convenções e tratados internacionais — por exemplo, as convenções de Paris e Berna, o Tratado de Cooperação em Matéria de Patentes (Patent Cooperation Treaty - PCT) ${ }^{62}$ e o Agreement on Trade-Related Aspects of Intellectual Property Rights (acordo TRIPs) ${ }^{63}$-, para permitir que os titulares estendessem a proteção de suas propriedades em diferentes países.

Hoje, no contexto de uma economia globalizada, com a produção industrial fragmentada em diversos países, nos parece lógico que a harmonização das legislações e a adoção de procedimentos padronizados nos países signatários dos tratados sejam as formas mais adequadas de garantir a efetividade da proteção, tornando as normas nacionais homogêneas e permitindo, assim, a extensão da proteção em diversos países por meio de procedimentos simplificados.

Evidentemente, o objeto principal da proteção internacional é a garantia dos direitos de exclusivo, permitindo que o titular tenha mecanismos apropriados para impedir a reprodução ilícita de sua criação, ou seja, a contrafação.

61 PEREIRA, Alexandre Dias, 2002, p. 24.

62 WIPO - WORLD INTELLECTUAL PROPERTY ORGANIZATION. Tratado de Cooperação em Matéria de Patentes (PCT). Disponível em: <http://www.wipo.int/export/sites/www/pct/pt/ texts/pdf/pct.pdf $>$. Acesso em: 15 jun. 2012.

63 WTO - WORLD TRADE ORGANIZATION. Acordo sobre aspectos dos direitos de propriedade intelectual relacionados ao comércio (acordo TRIPS ou acordo ADPIC). 1994. Disponível em: $<$ http://www.cultura.gov.br/site/wp-content/uploads/2008/02/ac_trips.pdf.> Acesso em 15 jun. 2012. 


\subsection{CONTRAFAÇÃo}

A ideia subjacente ao conceito de propriedade intelectual é que o inventor, ou autor, do novo bem divulgue a sua criação, dando conhecimento ao público, em troca de um título que lhe confira o direito de exclusivo sobre a criação determinada, dentro de limites temporais e espaciais previstos em lei.

O Estado, por sua vez, ao conferir o direito de exclusivo ao titular da criação, deve proporcionar mecanismos eficientes para assegurar a exclusividade na exploração de tal objeto pelo prazo determinado no título, impedindo que terceiros se utilizem indevidamente da criação divulgada pelo inventor, ou autor ${ }^{64}$.

Sendo assim, em regra, toda reprodução não autorizada pelo titular do direito de exclusivo é um ato de contrafação. Sem dúvida, o conceito de contrafação não está adstrito à proteção conferida às patentes de invenção e modelos de utilidade, visto que também se aplica às marcas, aos desenhos industriais e aos direitos de autor, todos titulares do direito de exclusivo sobre suas criações.

O legislador brasileiro não definiu a contrafação de patentes, limitando-se, no artigo 42 da Lei n. 9.279/96, a conferir ao titular da patente o direito de impedir que terceiro produza, use, coloque à venda, venda ou importe com tais propósitos: 1) produto objeto de patente ou 2) processo ou produto obtido diretamente por processo patenteado.

\footnotetext{
Art. 42. A patente confere ao seu titular o direito de impedir terceiro, sem o seu consentimento, de produzir, usar, colocar à venda, vender ou importar com estes propósitos:

I - produto objeto de patente;

II - processo ou produto obtido diretamente por processo patenteado.
}

64 Nesse sentido: "E a idéia básica subjacente a qualquer sistema de patentes é exatamente essa: o Estado incentiva o desenvolvimento e a divulgação de inovações técnicas ou tecnológicas de utilidade e aplicação industrial mediante a outorga, em contrapartida, de direitos de exclusivos de exploração das invenções por um determinado período de tempo. O interesse subjacente a esse escambo, assim como a sua eficiência em induzir à realização de esforços inventivos e à divulgação dos respectivos resultados, dependem intrinsecamente da garantia da liberdade de concorrência e da exploração de tecnologias não patenteadas." (SILVEIRA, Newton. Estudos e pareceres de propriedade intelectual. Rio de Janeiro: Editora Lumen Juris, 2008, p. 243). 
Igualmente, a contrafação não foi definida na Lei de Direitos Autorais e na Lei do Software. Entretanto, a despeito da falta de definição legal, podemos conceituar a contrafação com base na etimologia do termo. Contrafazer, etimologicamente, significa imitar, reproduzir ou apresentar de forma diferente.

Segundo De Plácido e Silva, contrafazer deriva da expressão "contrafacere", que se origina do baixo latim e significa reproduzir por imitação ${ }^{65}$. Hoje, o vocábulo “contrafazer", nos dicionários jurídicos contemporâneos, tem o significado de reprodução ou imitação ilícita, reprodução fraudulenta ou falsificação ${ }^{66}$, deixando de ser usado como sinônimo da simples reprodução e qualificando-se como a reprodução ilícita ou não autorizada.

Segundo o professor Balmes Vega Garcia, contrafazer “[...] seria reproduzir ou imitar ilicitamente o trabalho ou a obra de outra pessoa. Do que se depreende ser a contrafação não apenas a reprodução pura e simples, mas a reprodução aproximada. Por conseguinte, a própria imitação está inserida na definição de contrafação."67.

É importante observamos que a definição de contrafação abrange não só a reprodução idêntica como também outras formas de reprodução aproximada, como veremos mais à frente com o estudo das espécies de contrafação.

Segundo Gama Cerqueira, existem dois elementos constitutivos da contrafação: 1) a existência de um direito de exclusivo válido; 2) um fato material que constitua ofensa ao direito do concessionário do direito de exclusivo ${ }^{68}$. Já Paul Mathély apresenta elementos constitutivos distintos: 1) o objeto protegido deve ser reproduzido; 2) deve ser executado um ato de exploração do objeto contrafeito (ato de contrafação) ${ }^{69}$.

A caracterização da contrafação independe de prejuízo efetivo ao titular da patente. Também não há distinção entre a contrafação parcial e a total, bastando a usurpação de quaisquer de seus elementos essenciais ou característicos. Logo, o objeto da contrafação é

6 SILVA, De Plácido. Vocabulário jurídico. 15. ed. Rio de Janeiro: Forense, 2004. p. 371.

66 DINIZ, Maria Helena. Dicionário jurídico. São Paulo: Saraiva, 1998. p. 832.

67 GARCIA, Balmes Vega. Contrafação de patentes. São Paulo: Ltr, 2004. p. 65.

68 CERQUEIRA, João da Gama. 2010b, p. 274.

69 Cf. GARCIA, Balmes Vega, 2004, p. 59. 
aquele que agrupa em si os elementos essenciais, diferenciais, constitutivos da criação protegida.

Uma vez que não é necessário que todos os elementos essenciais sejam reproduzidos, basta a reprodução de algum desses elementos tidos como essenciais para que surja o objeto da contrafação. Assim, a contrafação pode abranger todos os elementos constitutivos da criação ou parte deles, pois não há distinção entre a contrafação parcial e a total, bastando a usurpação de quaisquer de seus elementos essenciais para caracterizá-la ${ }^{70}$.

Portanto, o primeiro elemento para a caracterização do objeto da contrafação não é o objeto supostamente contrafeito, e sim a existência de um direito de exclusivo válido, segundo Gama Cerqueira, ou de um objeto protegido somado a um ato de contrafação, segundo Paul Mathély.

\subsubsection{LiMitAÇÕES AO ATO DE CONTRAFAÇÃo}

A primeira limitação ao ato de contrafação é a limitação territorial, ou seja, a legislação brasileira protege apenas as criações protegidas no Brasil, em respeito ao princípio da territorialidade. Essa limitação não se aplica integralmente aos direitos autorais, uma vez que nesse caso a proteção se inicia com a criação. Já no direito industrial o direito de exclusivo é válido somente no Estado em que o pedido de patente ou registro foi depositado e, posteriormente, concedido.

Assim, a contrafação, no Brasil, de uma patente depositada no Canadá não constitui um ato de contrafação. Entretanto, como veremos, a importação, por terceiros, de um produto fabricado no exterior de acordo com processo de fabricação do mesmo produto patenteado no Brasil pode constituir um ato de contrafação ${ }^{71}$. Por outro lado, as obras

70 Em sentido contrário, Fernando Eid Phillipp diz que "[...] o titular da patente não pode se opor à exploração de um elemento de uma combinação, a não ser que ele a tenha reivindicado isoladamente.". (PHILIPP, Fernando Eid. Patente de invenção: extensão da proteção e hipóteses de violação. São Paulo: Juarez de Oliveira, 2006. p. 120).

71 PHILIPP, Fernando Eid, 2006, p. 143. 
literárias, artísticas e científicas produzidas em qualquer lugar do mundo são protegidas no Brasil independentemente de registro, na forma do artigo 12 da Lei de Direitos Autorais ${ }^{72}$.

A segunda limitação é de natureza temporal, isto é, a proteção da patente está condicionada ao período compreendido entre seu depósito e sua extinção. Tal período, na forma do artigo 40 da Lei $n^{0} 9.279 / 1996^{73}$, é de 20 anos para as patentes de invenção e de 15 anos para as de modelos de utilidade.

Como dito anteriormente, a proteção dos direitos patrimoniais de autor está limitada a 70 anos após o falecimento deste, na forma do artigo 41 da Lei n ${ }^{\circ}$ 9.610/1998. Já os direitos relativos a programas de computador são tutelados por 50 anos, contados a partir do ano subsequente ao da sua publicação (Lei $n^{\circ} 9.609 / 1998$, art. $2^{\circ}, \S 2^{\circ}$ ).

Assim, o ato de contrafação deve se consumar dentro do período de validade do direito, não havendo contrafação na hipótese de o direito ter se perdido por decisão que declare sua nulidade ou caducidade.

Além disso, a oponibilidade das patentes perante terceiros está sujeita às restrições do artigo 44 do mesmo diploma legal, pois, uma vez que a patente fica em sigilo pelo período de 18 meses após o depósito, não seria plausível que terceiros estivessem sujeitos a eventuais sanções de um pedido de patente que ainda não foi divulgado.

Dessa forma, os atos de contrafação cometidos tornam-se puníveis a partir da publicação do pedido de patente ou de eventual notificação enviada ao contrafator pelo titular do pedido ${ }^{74}$, como forma de ciência inequívoca do pedido depositado, na forma prevista pelo parágrafo $1^{\circ}$ do artigo 44 da Lei $n^{0} 9.279 / 1996^{75}$.

72 “Art. 18. A proteção aos direitos de que trata esta Lei independe de registro."

3 "Art. 40. A patente de invenção vigorará pelo prazo de 20 (vinte) anos e a de modelo de utilidade pelo prazo 15 (quinze) anos contados da data de depósito."

74 Nesse sentido: PHILIPP, Fernando Eid, 2006, p. 157.

75 Cumpre aqui observar que a notificação ou a publicação só tem efeito retroativo para os casos de indenização civil pela contrafação, pois antes da concessão o titular do pedido só tem uma mera expectativa de direito, que será ou não concretizada após a concessão da patente pelo INPI. Tratamento similar é dado às patentes de material biológico, cujo direito de indenização está condicionado ao momento no qual o material biológico tiver se tornado acessível ao público. 


\title{
1.3.2 APRECIAÇÃo DA CONTRAFAÇÃo
}

A apreciação da contrafação deve obedecer a três etapas essenciais, em que inicialmente se aprecia o objeto patenteado conforme sua proteção, em seguida se identifica o objeto incriminado e, por fim, se comparam os objetos protegido e incriminado, segundo as normas jurídicas vigentes.

\begin{abstract}
A doutrina em geral afirma que, para a apreciação da contrafação, devem ser comparados o objeto patenteado e o objeto presumidamente contrafeito. Entretanto, engana-se aquele que pensa, de acordo com essa afirmação, que a simples comparação estética e aparente desses dois objetos é suficiente. ${ }^{76}$
\end{abstract}

$\mathrm{Na}$ verdade, esse tipo de comparação estética e aparente levaria o observador a cometer o erro de comparar os objetos por suas diferenças, e como veremos, a apreciação da contrafação deve ser realizada com base em suas semelhanças.

Identificados os objetos patenteado e incriminado, passa-se à comparação entre eles segundo duas regras fundamentais.

A primeira regra é verificar se a reprodução atinge a própria essência do objeto protegido, ou seja, se existe, no objeto incriminado, reprodução dos elementos essenciais constitutivos do objeto protegido. Assim, a contrafação só existe se houver no objeto incriminado os elementos essenciais e constitutivos do objeto protegido, o que deve ser reproduzido é a própria essência da invenção. A segunda regra, como dissemos, é analisar a contrafação pelas semelhanças entre os dois objetos, e não pelas diferenças entre eles, pois as diferenças acrescidas não excluem a reprodução dos elementos essenciais ${ }^{77}$.

\footnotetext{
Dissemos também que, para verificar-se a infração, basta que tenha sido usurpara a idéia da invenção, objeto do privilégio. Qualquer modificação introduzida na forma, nas dimensões ou nas proporções do objeto, bem como a substituição de matéria, não excluem a contrafação. Estão no mesmo caso a substituição de peças ou órgãos de um maquinismo privilegiado por outro elemento equivalente, ou a sua modificação sem alteração das funções que desempenham, a substituição de substâncias de um produto químico por outro análogo. Toda a questão gira em torno deste ponto: saber se a idéia essencial da invenção foi usurpada. ${ }^{78}$
}

76 PHILIPP, Fernando Eid, 2006, p. 149.

77 Cf. GARCIA, Balmes Vega, 2004, p. 66.

78 CERQUEIRA, João da Gama. 2010b, p. 280. 
Partindo dessas premissas, podemos dividir as contrafações em quatro espécies: reprodução servil, contrafação com alterações acessórias, contrafação por equivalência e contrafação por aperfeiçoamento.

\subsubsection{ESPÉCIES DE CONTRAFAÇÃo}

A primeira espécie de contrafação é a cópia vil, ou seja, a simples cópia do objeto protegido, ou a reprodução integral, também denominada de "reprodução servil", 79 .

A segunda espécie de contrafação é a contrafação com alterações acessórias doutrina das variantes de execução. Nesse caso, o objeto incriminado traz pequenas diferenças em detalhes que não retiram o caráter de contrafação, porque reproduzem os elementos essenciais do objeto protegido.

Já ensinava Gama Cerqueira, acerca dessa espécie, que, desde que a ideia essencial da invenção tenha sido usurpada, está caracterizada a contrafação, sendo indiferentes as modificações acidentais, de forma ou de aspecto introduzidas no produto ou no processo patenteado $^{80}$.

A terceira espécie de contrafação é a contrafação por equivalência, ou seja, a que ocorre quando um elemento da estrutura da invenção é substituído por um elemento distinto que desempenha a mesma função para alcançar um resultado semelhante. Cabe aqui observar que, segundo a teoria dos equivalentes, o conceito de equivalência compreende três elementos distintos: forma, função e resultado.

Observe-se que a equivalência ocorre quando dois meios, ainda que tenham formas diferentes, atingem resultados semelhantes, desde que sua função seja idêntica e que busquem resultados semelhantes ou parecidos. Isso significa que, apesar de terem formas

79 Cf. GARCIA, Balmes Vega, 2004, p. 67.

80 Nesse sentido: CERQUEIRA, João da Gama, 2010b, p. 280. 
distintas, se a função dos objetos for idêntica e o resultado for semelhante, teremos uma contrafação por equivalência ${ }^{81}$.

A quarta espécie de contrafação é a contrafação por aperfeiçoamento: toda vez que se realiza um aperfeiçoamento no objeto de base, aderindo melhoramentos que aumentem a eficiência ou melhorem o objeto de base em qualquer de suas características ${ }^{82}$, a produção do objeto aperfeiçoado prescinde de licença ${ }^{83}$ do detentor do direito de exclusivo do objeto de base.

\subsubsection{ATOS DE CONTRAFAÇÃO}

O primeiro ato de contrafação é aquele que se concretiza pela produção ou pela fabricação do produto. A fabricação do produto deve ser entendida como a reprodução material do produto patenteado, que será considerada como contrafação toda vez que for realizada sem a autorização do titular da patente.

A simples reprodução material constitui a contrafação, mesmo que o produto ainda esteja nas instalações onde foi produzido e independentemente da destinação pretendida a ele — venda, uso, etc. —, uma vez que a norma prevista no artigo 42 da Lei n ${ }^{0}$ 9.279/1996 autoriza o titular da patente a impedir terceiros de produzi-lo.

81 “Tal princípio teve sua definição mais precisa na decisão da Suprema Corte dos Estados Unidos no caso Winam v. Denmead, 56 US. (15 How) 330 (1953): 'copiar o princípio ou modo de operação descrito é uma violação de patente, embora tal cópia seja diversa em forma ou em proporção'. Em outras palavras, o que se patenteia é a função. A Suprema Corte detalha esta matéria na decisão do caso Graver Tam \& Mfg. Co. v. Linde Air Prodets. Co. 339 U. S. 605, (1950). 'Equivalência, do direito patentário, não é o prisioneiro de uma fórmula e não é um absoluto que deva ser considerado no vácuo. Não se exige identidade completa para todo propósito e em todo caso. Ao determinar equivalentes, coisas que são iguais a mesma coisa podem não ser iguais entre si e, da mesma maneira, coisas que são diferentes para a maior parte dos objetivos, podem ser às vezes equivalentes. Tem-se que dar atenção ao propósito para o qual cada ingrediente é usado numa patente, às qualidades que tal ingrediente tem quando combinado com outros ingredientes, e a função que ele deve desempenhar'." (BARBOSA, Denis Borges. Da doutrina dos equivalentes em direito de patentes. Disponível em: <http://denisbarbosa.addr.com/ equivale.pdf>. Acesso em: 29 maio 2011.

82 Os aperfeiçoamentos podem ser objeto de patente independente e válida, mas o pedido de patente deve reivindicar apenas o aperfeiçoamento, não sendo lícito reivindicar o objeto como um todo, incluindo a patente de base.

83 A licença, no caso de patentes, pode ser voluntária ou compulsória, na forma dos artigos 68 a 74 da Lei $n^{\circ} .9 .279 / 1996$. 
A caracterização da contrafação por fabricação independe da destinação que será dada ao produto e, da mesma forma, independe do dolo do contrafator, pouco importando a boa-fé, a ignorância a respeito da existência da patente, a crença em sua nulidade ou em sua expiração, a ausência de vontade de contrafazer, etc ${ }^{84}$.

Em compensação, a simples tentativa de fabricação, sem sua efetiva materialização, não é considerada contrafação. Em sentido contrário, parte da doutrina entende que a contrafação se consuma pela fabricação de parte dos elementos essenciais da patente, ou seja, pela fabricação inacabada.

Em relação ao elemento subjetivo, cumpre observar que, quando se trata de uma contrafação de um equipamento que envolve mais de uma pessoa, o elemento subjetivo passa a ter importância na caracterização da contrafação. Primeiro, porque, se observarmos a situação do empregado do contrafator, é evidente que ele só obedece a ordens e não pode ser apenado pela ilicitude dos atos de seu empregador ${ }^{85}$. Segundo, se observarmos a situação do empreiteiro, este igualmente deve ser excluído em casos de boa-fé ${ }^{86}$. Dessa forma, não podemos desconsiderar por completo o elemento subjetivo quanto à autoria.

O segundo tipo de contrafação diz respeito ao uso do produto/processo, que abrange o uso tanto do produto licitamente fabricado quanto do produto contrafeito. Nesse sentido, pouco importa se a aquisição do produto é lícita, mas sim se o uso para aquela finalidade estava autorizado pelo titular da patente $^{87}$.

Logo, a contrafação pelo uso de produto ou processo ocorrerá quando se usar um produto contrafeito ou quando o uso de produto legítimo tiver caráter comercial ou industrial e não tiver sido autorizado quando da aquisição do produto ${ }^{88}$. Situação análoga ocorre com a exibição comercial de filmes ou outras obras audiovisuais adquiridas para exibições privadas, caso em que a aquisição do exemplar não autoriza a exploração comercial daquela cópia.

Cf. GARCIA, Balmes Vega, 2004, p. 77.

5 Nesse sentido: PHILIPP, Fernando Eid, 2006, p. 130.

86 Cf. GARCIA, Balmes Vega, 2004, p. 81.

87 Cf. GARCIA, Balmes Vega, 2004, p. 82.

88 Cf. PHILIPP, Fernando Eid, 2006, p. 131. 
A comercialização do produto contrafeito é o terceiro tipo de contrafação. Se a contrafação pela fabricação não traz benefícios financeiros ao contrafator, a colocação do produto no mercado após a fabricação, por sua vez, causa prejuízos efetivos ao titular da patente.

\footnotetext{
Concluída a fabricação, o contrafator, tendo despendido tempo e dinheiro, ainda não extraiu proveito de seu ato. $\mathrm{O}$ contrafator manufatura seu produto com o propósito de colocá-lo no mercado, obtendo o conseqüente retorno financeiro em detrimento do titular. ${ }^{89}$
}

A contrafação pela comercialização se subdivide em contrafação pela venda, pela colocação à venda e pela importação. Nas duas primeiras formas, abrange-se tanto a oferta quanto a exposição do produto e a própria venda deste ${ }^{90}$.

A contrafação pela importação, traz um mecanismo lógico ao sistema, uma vez que a proteção da patente está restrita ao território nacional (princípio da territorialidade) e seu titular no Brasil não pode impedir a fabricação do produto em país no qual não tenha depositado sua patente.

Por outro lado, é necessário que o titular possa impedir eventual importação do produto fabricado no exterior em violação à sua patente. Caso contrário, seria muito fácil violar determinada patente transferindo a produção para um país onde não existe patente depositada e importando, em seguida, o produto pronto ${ }^{91}$.

Nos casos de contrafação por importação, respondem pela contrafação tanto o importador brasileiro que importa o produto objeto de patente no Brasil quanto o fabricante estrangeiro que o remete, pois o fabricante tem obrigação de saber para qual país está exportando o produto e se naquele país existe patente depositada que proteja aquele produto.

89 GARCIA, Balmes Vega, 2004, p. 85-86.

90 Salientamos que a simples oferta, independentemente da efetiva exposição à venda do produto, já caracteriza o ato de contrafação, uma vez que a terminologia utilizada pelo legislador no caput do artigo 42 da Lei n. 9.279/1996 foi "colocar à venda", o que abrange tanto as situações de simples oferta como as de exposição à venda.

91 Cf. PHILIPP, Fernando Eid, 2006, p. 136. 


\subsubsection{IMUNIDADES}

A primeira imunidade prevista na legislação brasileira é a disciplinada pelo inciso I do artigo 43 da Lei ${ }^{\circ}$ 9.279/1996, que estabelece que as regras de proteção não se aplicam aos atos praticados por terceiros não autorizados, em caráter privado e sem finalidade comercial, desde que não acarretem prejuízo ao interesse econômico do titular da patente.

Essa imunidade isenta o consumidor final de produto fabricado em violação de uma patente de ser acionado pelo titular desta, desde que tal consumo não tenha finalidade comercial.

A segunda imunidade, prevista no inciso II do artigo 43, estabelece que as regras de proteção não se aplicam aos atos praticados por terceiros não autorizados, com finalidade experimental, relacionados a estudos ou pesquisas científicas ou tecnológicas.

Essa imunidade permite o uso da invenção com finalidade estritamente experimental e relativo a estudos ou investigação científica. Segundo o professor Balmes, a exceção abrange os estudos para aperfeiçoamento e o ciclo de scale-up ${ }^{92}$.

A terceira imunidade prevista no artigo 43 , em seu inciso III, estabelece que as regras de proteção não se aplicam à preparação de medicamento de acordo com prescrição médica para casos individuais, executada por profissional habilitado, bem como ao medicamento assim preparado.

Essa imunidade beneficia as farmácias de manipulação, onde se prepara um medicamento caso a caso, mediante receita médica, com produção artesanal, e não industrial. Existe discussão sobre a importação de matéria-prima para esse fim, pois, segundo os comentários à lei publicados pelos membros do Instituto Dannemann Siemsem de Estudos da Propriedade Intelectual ${ }^{93}$, essa importação estaria fora das situações de imunidade previstas.

92 GARCIA, Balmes Vega, 2004, p. 97.

93 INSTITUTO DANNEMANN SIEMSEM DE ESTUDOS DA PROPRIEDADE INTELECTUAL. Comentários à lei da propriedade industrial. Rio de Janeiro: Renovar, 2005. p. 93. 
A quarta imunidade descrita no artigo 43 (inciso IV) prevê que, nos casos em que o próprio titular da patente coloca o produto no mercado interno ou consente que terceiro o faça, não pode controlar as condições em que o comprador disporá do produto.

É clara a menção ao "mercdo interno/nacional", isto é, o titular da patente não pode impedir terceiro, sem seu consentimento, de (re)vender produto posto no mercado interno pelo titular ou com seu consentimento. [...] Não existe diferença substancial, como se vê, no conteúdo dos direitos patentário e mmarcário. Para ambos, são conferidos direitos amplos nos quais se inclui o poder de excluir terceiros da prática de atos não autorizados pelos titulares dos direitos. ${ }^{94}$

Da mesma forma, pelo princípio da exaustão interna, o titular da patente que a explora apenas pela via da importação, não fabricando o produto no Brasil, não pode evitar a importação paralela de produto fabricado no exterior de acordo com a patente $(\text { licenciado })^{95}$.

Os incisos V e VI do artigo 43 estabelecem os casos que limitam a ação do titular da patente cujo objeto seja matéria viva, que pode ser utilizada para a obtenção de diferentes produtos. Não caracterizam contrafação a utilização, sem finalidade econômica, de matéria viva patenteada como fonte inicial para obtenção de novos produtos nem a aquisição, sem finalidade comercial de propagação ou multiplicação comercial, de exemplar da matéria viva ${ }^{96}$.

O artigo 43 recebeu um novo inciso, acrescentado pela Lei ${ }^{\circ} 10.196 / 2001^{97}$, que criou uma nova imunidade, voltada para os casos de uso não autorizado do objeto da patente para a produção de informações, dados e resultados de teste com a finalidade de preparação para a produção e a comercialização tão logo expire o direito de exclusivo.

Tal imunidade permite que o mercado se prepare para explorar o objeto de uma determinada patente quando da expiração do direito de exclusivo, evitando, assim, que o direito de exclusivo se prolongue até que os concorrentes tenham know-how para a produção em escala daquele produto.

94 BASSO, Maristela. Propriedade intelectual e importação paralela. São Paulo: Editora Atlas, 2011, p. 70.

95 Cf. GARCIA, Balmes Vega, 2004, p. 99.

96 Cf. GARCIA, Balmes Vega, 2004, p. 97.

97 BRASIL. Lei no 10.196, de 14 de fevereiro de 2001. Altera e acresce dispositivos à Lei no 9.279, de 14 de maio de 1996, que regula direitos e obrigações relativos à propriedade industrial, e dá outras providências. Disponível em: <http://www.planalto.gov.br/ccivil_03/leis/LEIS_2001/L10196.htm>. Acesso em: 28 nov. 2012. 
$\mathrm{O}$ artigo 45 estabelece a imunidade ao usuário anterior - aquele que, antes da data de depósito, produzia produto objeto de patente - para manter a exploração, sem ônus, na forma e na condição anteriores.

As imunidades previstas para os casos de direitos autorais estão disciplinadas no artigo 46 da Lei $n^{\circ} 9.610 / 1998$, que estabelece que:

Art. 46. Não constitui ofensa aos direitos autorais:

I - a reprodução:

a) na imprensa diária ou periódica, de notícia ou de artigo informativo, publicado em diários ou periódicos, com a menção do nome do autor, se assinados, e da publicação de onde foram transcritos;

b) em diários ou periódicos, de discursos pronunciados em reuniões públicas de qualquer natureza;

c) de retratos, ou de outra forma de representação da imagem, feitos sob encomenda, quando realizada pelo proprietário do objeto encomendado, não havendo a oposição da pessoa neles representada ou de seus herdeiros;

d) de obras literárias, artísticas ou científicas, para uso exclusivo de deficientes visuais, sempre que a reprodução, sem fins comerciais, seja feita mediante o sistema Braille ou outro procedimento em qualquer suporte para esses destinatários;

II - a reprodução, em um só exemplar de pequenos trechos, para uso privado do copista, desde que feita por este, sem intuito de lucro;

III - a citação em livros, jornais, revistas ou qualquer outro meio de comunicação, de passagens de qualquer obra, para fins de estudo, crítica ou polêmica, na medida justificada para o fim a atingir, indicando-se o nome do autor e a origem da obra;

IV - o apanhado de lições em estabelecimentos de ensino por aqueles a quem elas se dirigem, vedada sua publicação, integral ou parcial, sem autorização prévia e expressa de quem as ministrou;

V - a utilização de obras literárias, artísticas ou científicas, fonogramas e transmissão de rádio e televisão em estabelecimentos comerciais, exclusivamente para demonstração à clientela, desde que esses estabelecimentos comercializem os suportes ou equipamentos que permitam a sua utilização;

VI - a representação teatral e a execução musical, quando realizadas no recesso familiar ou, para fins exclusivamente didáticos, nos estabelecimentos de ensino, não havendo em qualquer caso intuito de lucro;

VII - a utilização de obras literárias, artísticas ou científicas para produzir prova judiciária ou administrativa;

VIII - a reprodução, em quaisquer obras, de pequenos trechos de obras preexistentes, de qualquer natureza, ou de obra integral, quando de artes plásticas, sempre que a reprodução em si não seja o objetivo principal da obra nova e que não prejudique a exploração normal da obra reproduzida nem cause um prejuízo injustificado aos legítimos interesses dos autores.

Entretanto, o parágrafo $4^{\circ}$ do artigo 184 do Código Penal, acrescido pela Lei $n^{\circ}$ $10.695 / 2003$, estabeleceu a imunidade para a cópia de obra intelectual ou fonograma, em um só exemplar, para uso privado do copista, sem intuito de lucro direto ou indireto, derrogando, a nosso ver, a norma prevista no inciso II do artigo 46 da Lei $n^{\circ}$ 9.610/1998. 
Por fim, as imunidades previstas em relação aos direitos dos titulares dos programas de computador estão disciplinadas no artigo $6^{\circ}$ da Lei $n^{\circ} 9.609 / 1998$, que estabelece que:

\begin{abstract}
Art. $6^{\circ}$ Não constituem ofensa aos direitos do titular de programa de computador:

I - a reprodução, em um só exemplar, de cópia legitimamente adquirida, desde que se destine à cópia de salvaguarda ou armazenamento eletrônico, hipótese em que o exemplar original servirá de salvaguarda;

II - a citação parcial do programa, para fins didáticos, desde que identificados o programa e o titular dos direitos respectivos;

III - a ocorrência de semelhança de programa a outro, preexistente, quando se der por força das características funcionais de sua aplicação, da observância de preceitos normativos e técnicos, ou de limitação de forma alternativa para a sua expressão;

IV - a integração de um programa, mantendo-se suas características essenciais, a um sistema aplicativo ou operacional, tecnicamente indispensável às necessidades do usuário, desde que para o uso exclusivo de quem a promoveu.
\end{abstract}

Cumpre aqui observar que o inciso III do artigo $6^{\circ}$ da Lei $n^{\circ} 9.609 / 1998$ afasta a aplicabilidade das hipóteses de contrafação por equivalência dos programas de computador, uma vez que é natural que ocorram diversas semelhanças entre os programas concorrentes, que visam exatamente o mesmo resultado.

Portanto, ressalvados os casos que se enquadrem nas hipóteses de imunidade previstas na legislação, todos os demais atos de contrafação estão sujeitos a sanções civis e penais.

\title{
1.4 CONTRAFAÇ̃̃o E PIRATARIA
}

Pirataria, palavra muito difundida em nossa sociedade, não é, evidentemente, uma definição de natureza técnica ou jurídica. Trata-se apenas de uma figura de retórica, quase que uma gíria, mas com significado amplo e grave e que poderia ser resumido à idéia de que todo produto falsificado com vistas a ocupar o lugar do verdadeiro no mercado, burlando o fisco e produzindo prejuízos materiais e morais a terceiros, pode assim ser designado. A pirataria foi recentemente recepcionada como sinônimo do contrabando e da falsificação de produtos, vez que tais condutas, entre outras descritas, pilham o patrimônio do legítimo proprietário da mercadoria, prejudicam o Estado com a evasão fiscal e, tal como os piratas do passado, os criminosos de hoje não se importam com os prejuízos decorrentes de seus atos ilícitos. ${ }^{98}$

98 BRASIL, Relatório da Comissão Parlamentar de Inquérito. Finalidade: investigar fatos relacionados à pirataria de produtos industrializados e à sonegação físcal, Brasília, 2004. Disponível em: $<$ http://www2.camara.leg.br/atividade-legislativa/comissoes/comissoes-temporarias/parlamentar-deinquerito/52-legislatura/cpipirat/relatoriofinal.pdf>. Acesso em: 30 dez. 2012. 
Apesar de terem origem histórica distinta, tanto o direito autoral como o direito industrial enfrentam, hoje, a mesma problemática — a pirataria —, como resultado da popularização dos mecanismos de produção e reprodução de produtos; do baixo custo de produção em relação ao custo comercial dos produtos originais; da facilidade de romper e reproduzir os mecanismos de segurança e identificação de produtos originais; e da velocidade da indústria de cópias transnacional, que lança no mercado produtos piratas quase que simultaneamente aos produtos originais.

Os produtos comercializados em suportes materiais como CDs, DVDs, Blu-rays e HD-DVDs, em especial vídeos, filmes, álbuns musicais e programas de computador, enfrentam o primeiro problema: a popularização dos meios de armazenamento nesse tipo de mídia, que serve ao mesmo tempo para a comercialização desse tipo de produto e para o armazenamento legítimo de arquivos de computador, vídeos, filmes, álbuns musicais e programas de computador caseiros, experimentais, científicos, personalizados ou não profissionais.

Praticamente todos os microcomputadores estão adaptados para a gravação de CDs e DVDs virgens, ficando excluídos apenas — no caso dos microcomputadores mais populares - os gravadores de discos Blu-ray e HD-DVD ${ }^{99}$, com maior capacidade de armazenamento. Por esse motivo, não se pode limitar os recursos de cópias em CDs e DVDs, visto que seu uso precípuo é lícito e apenas os desvios são ilícitos.

A popularização dos gravadores de CDs e DVDs permite que qualquer usuário copie produtos originais compartilhando-os entre os seus próprios dispositivos eletrônicos, mas as cópias não se restringem necessariamente aos dispositivos do usuário que adquiriu

99 "A principal diferença entre os formatos é a capacidade de armazenamento, com vantagem para o Bluray, que armazena $25 \mathrm{~GB}$ em discos de uma camada (50 GB em duas camadas), contra 15 GB do HDDVD de uma camada (30 GB em duas camadas). Por conta do maior espaço disponível, setores da indústria acreditam que o Blu-ray tenha preferência maior em aplicações de informática (software, games, backup) em contrapartida aos filmes. As capacidades diferentes ocorrem por conta da diferença no método de gravação dos dados. Mas as diferenças técnicas entre os dois formatos quase não existem. $\mathrm{O}$ HD-DVD tem como empresa líder a Toshiba, com suporte da Microsoft, Sanyo, NEC e estúdios de Hollywood como New Line e Universal. O Blu-ray, da Sony, tem parcerias com Apple, Panasonic, Philips, Samsung, Sharp e outros estúdios de cinema." (REBÊLO, Paulo. Blu-ray e HD-DVD: entenda as diferenças e veja se vale investir. UOL, São Paulo, 2 mar. 2007. Disponível em: $<$ http://tecnologia.uol.com.br/ultnot/2007/03/02/ult4213u43.jhtm>. Acesso em: 29 dez. 2012). 
o produto original, podendo ser compartilhadas, sem qualquer perda de qualidade, com outras pessoas ilimitadamente.

Se a tecnologia está disponível para o uso doméstico, é evidente que também está disponível para o uso comercial ilícito, e uma avalanche de álbuns musicais, vídeos, filmes e programas de computador pirateados inunda o mercado mundial, podendo ser encontrada, indistintamente, em qualquer centro urbano do mundo. Paralelamente, inúmeros métodos de transferência de arquivos pela internet foram criados, permitindo que os usuários obtenham o mesmo conteúdo pela internet, em servidores de download e upload e por meio de torrents $^{100}$, podendo gravá-los em CDs e DVDs.

Os produtos industriais, por sua vez, também são objeto de pirataria, que consegue colocar no mercado réplicas com preços substancialmente inferiores aos preços dos produtos originais, porque os produtos originais estão sujeitos à alta carga tributária do mercado formal, aos custos de pesquisa e desenvolvimento dos produtos e aos encargos trabalhistas e previdenciários dos empregados desde a produção até a comercialização.

Por outro lado, os produtos piratas normalmente são vendidos sem o pagamento de qualquer imposto, não há qualquer investimento em pesquisa e desenvolvimento e, na maioria das vezes, na própria produção e na comercialização não são respeitados os direitos trabalhistas e previdenciários dos empregados, pela própria ilegalidade da atividade $^{101}$. Assim, tais produtos são muito mais baratos que os originais e, por esse motivo, atraem uma infinidade de consumidores que não podem adquirir os originais ou ficam atraídos pela oportunidade dos produtos falsificados.

100 "O mecanismo funciona com a seguinte lógica: os arquivos são divididos em partes pequenas, que podem ser acessadas e obtidas por outros internautas assim que são baixadas para o computador de cada usuário. Como o arquivo não precisa ser baixado completamente para ser compartilhado, o download costuma ser mais rápido que em outros sistemas $\mathrm{P} 2 \mathrm{P}$ (peer-to-peer, que possibilita a troca de arquivos on-line) como o eMule, especialmente para conteúdos mais novos ou que estejam 'na moda' e sejam muito requisitados. Isso porque a velocidade geralmente é maior quando há muitos internautas baixando um item ao mesmo tempo." (ENTENDA como funciona o sistema torrent para compartilhar arquivos na web. Folha Online. São Paulo, 17 abr. 2009. Disponível em: <http://www1.folha.uol.com.br/folha/informatica/ ult124u552200.shtml>. Acesso em: 30 dez. 2012).

101 “Assim, o mercado de falsificações está intimamente ligado à informalidade, mesmo que possa nascer no seio de empresas regulamentadas, uma vez que ele exige um ritmo intensivo de mão-de-obra. Além disso, o preço baixo não seria mantido se fossem pagos todos os impostos e se os funcionários trabalhassem dentro da carga horária permitida." (PINHEIRO-MACHADO, Rosana. Made in China: produção e circulação de mercadorias no circuito China-Paraguai-Brasil. 2009. 332 f. Tese (Doutorado em Antropologia Social) - Instituto de Filosofia e Ciências Humanas, Universidade Federal do Rio Grande do Sul, Porto Alegre, 2009. p. 129). 
Tanto os produtos objeto de proteção de direitos de autor e de autor de software quanto os produtos industriais, para enfrentar as cópias ilegais desenvolveram mecanismos de segurança e mecanismos anticópia instalados em CDs, DVDs, Blu-rays e HD-DVDs, selos, etiquetas e outros elementos de segurança para distinguir os originais das cópias, respectivamente. Nada adiantou.

Na mesma velocidade que um mecanismo de segurança ou anticópia é instalado, inúmeros programas para inibir a ação de tais mecanismos são disponibilizados em blogs, páginas de internet e fóruns de discussões de usuários especializados em todos os dispositivos disponíveis, com quaisquer tipo de sistemas operacionais de dispositivos eletrônicos, permitindo que os usuários multipliquem as cópias sem a menor dificuldade. Da mesma forma, os selos, as etiquetas e outros elementos de segurança dos produtos industriais são replicados com a mesma qualidade dos próprios produtos, aumentando a dificuldade do consumidor em distinguir o original da cópia, exceto pela significativa diferença de preço.

Por fim, o último fator que agrava o problema da pirataria é a indústria transnacional que se desenvolveu no setor, pois, da mesma forma como as grandes corporações distribuem a produção nos países cujos custos representam significativa redução de preços de produção, a indústria da cópia também se aproveita das mesmas facilidades para o seu desenvolvimento.

Atualmente, China e Vietnã são os países que dispõem do setor industrial mais vantajoso para o processo produtivo das grandes empresas, as quais terceirizam em diversos estabelecimentos a fabricação de seus produtos; por outro lado, ao transferir a produção para esses países, as empresas enfrentam o problema da pirataria, visto que os segredos industriais, os métodos de produção, a qualidade dos materiais, etc., são parcialmente transferidos para as industriais locais e ficam vulneráveis às cópias ${ }^{102}$.

[...] dado o emaranhado de empresas, terceirização e padronização da produção na China, hoje em dia, produtos falsos e cópias podem ser feitos nos mesmos lugares (no caso da fábrica de brinquedos) ou serem montados através dos mesmos componentes (no caso, as fivelas). Nestes casos que diferem da réplica

${ }^{102}$ Cf. PINHEIRO-MACHADO, Rosana. 2009, p. 117. 
de um produto de luxo, a linha que se separa o original do falso, é muito tênue, inclusive em suas propriedades materiais. ${ }^{103}$

$\mathrm{Na}$ China, em especial, a indústria da cópia chegou a tal nível de sofisticação que existem diversas gradações de cópias, desde as de primeira linha até as mais grosseiras, diferenciando-se principalmente pelo nível de acabamento, pelos materiais empregados e pela proximidade do produto original. Mas o que mais se destaca é a velocidade na reprodução das réplicas ilegais, que chegam ao mercado quase simultaneamente com os produtos originais $^{104}$.

Entretanto, apesar de a problemática ser a mesma - combate à pirataria - 0 sistema de proteção penal da propriedade imaterial é dividido conforme a espécie da propriedade protegida (direito de autor, direito de autor de software e direito industrial), e não de acordo com o tipo de contrafação, separando a repressão da contrafação por reprodução servil das demais espécies de contrafação (por variantes de execução, por equivalência e por aperfeiçoamento). Isso reduz a eficiência do sistema de proteção, seja pela falta de isonomia entre os tipos de contrafação, seja pela falta de clara definição do que se pretende combater (a pirataria).

103 PINHEIRO-MACHADO, Rosana, 2009, p. 133.

104 “Em minha vista à fábrica 'italiana', ganhei vários produtos recém lançados no mercado. Na volta, o motorista da empresa me deixou em Louhu, onde eu passaria pela imigração e tomaria meu trem para Hong Kong. É ali, curiosamente no mesmo prédio onde se situa a polícia aduaneira, que está instalado o LouHu Shopping. Não resisti e fui à loja onde costumava fazer observação. Chamei a vendedora que, àquela altura já era minha amiga, e pedi para que ela me conseguisse as cópias das bolsas que eu ganhara na fábrica. Eu gostava daquela loja, pois, além de ter uma vendedora simpática, a qualidade das cópias eram muito superiores às outras que encontrara noutros lugares. Uma das bolsas que ela me mostrou, causara-me um verdadeiro choque: era exatamente a mesma que recém tinha sido o seu projeto liberado da Itália e que, minutos atrás, eu havia visto nos computadores do escritório." (PINHEIRO-MACHADO, Rosana, 2009, p. 135) 


\title{
CAPÍTULO II - PROTEÇÃO PENAL DA PROPRIEDADE INTELECTUAL
}

\subsection{Generalidades}

No capítulo anterior pudemos analisar o conceito de contrafação, que vai muito além da simples cópia vil do bem protegido, abrangendo a contrafação por variantes de execução, por equivalência e por aperfeiçoamento.

O conceito de contrafação se desenvolveu em um sistema baseado na escassez das matérias-primas e dos suportes materiais necessários à reprodução da ideia, época em que as tecnologias necessárias para a reprodução da obra não estavam ao alcance dos interessados e o custo de reprodução não compensava a contrafação da obra.

\begin{abstract}
O suporte material da obra, que até então era predominantemente o papel, foi substituído por dispositivos de armazenamento magnéticos (disquetes, discos rígidos etc.) e ópticos (CDs, DVDs etc.) de baixíssimo custo e com grande capacidade, possibilitando a qualquer pessoa ter gigantescas bibliotecas pessoais em formato digital. $\mathrm{O}$ serviço necessário à reprodução da obra foi minimizado a ponto de ser realizado pessoalmente pelo próprio interessado em questão de minutos. O custo de reprodução de volumosas coleções de livros tornou-se praticamente insignificante. $^{105}$
\end{abstract}

Essa nova realidade implica a necessidade de repensar o sistema de proteção da propriedade intelectual, que não pode mais estar baseado na ideia da cópia e deve buscar novos paradigmas. Diante desse novo panorama, Lawrence Lessig, professor de direito na universidade de Stanford, criou uma modalidade de licenças de direitos autorais denominada "Creative Commons"106, que, apesar de sofrer severas críticas, se propõe a apresentar uma alternativa ao atual sistema de proteção - neste, a proteção está centrada na ideia de controle das cópias.

Em entrevista para o periódico O Estado de São Paulo, Lessig enfatizou que

105 VIANNA, Túlio Lima, 2005, p. 11.

106 "As licenças da Creative Commons permitem copiar, distribuir, apresentar ou representar publicamente um conteúdo, transformando-o. Elas não podem ser alteradas, devem ser indicadas no conteúdo disponibilizado e recursos tecnológicos não podem ser aplicados para restringir o seu uso. Adotam os seguintes conceitos em relação ao conteúdo licenciado, representando-os por símbolos: a sua atribuição ao autor/criador do original, a impossibilidade de uso comercial, a impossibilidade de derivação de novos conteúdos e o compartilhamento pela mesma licença." (ZANAGA, Mariângela Pisoni. Conteúdos abertos na educação motivações e visão de autoria. 2006. 192 f. Tese (Doutorado em Educação) - Faculdade de Educação, Universidade Estadual de Campinas, Campinas, 2006. p. 27). 
[...] a razão pela qual todos somos piratas hoje é porque a lei atual é baseada na reprodução de cópias. É uma lei que fazia sentido nos séculos 18 e 19, pois elas lidavam com cópias feitas por meio de novas tecnologias, que não estavam ao alcance de todos. [...] Mas estamos nos movendo para uma era em que todo mundo que acessa a cultura tecnicamente faz cópias. Faz tanto sentido regular isso como regular o ato de respirar - copiar é algo tão comum que qualquer um pode fazer. Ao invés de invocar essa lei insana toda vez que um garoto liga o computador, a lei deveria parar de focar na cópia e se focar em atividades que façam sentido comercialmente. ${ }^{107}$

Não estamos aqui defendendo o Creative Commons, mas concordamos com o professor Lessig que é necessário repensar o sistema de proteção da propriedade imaterial, uma vez que, ao invés de se pensar em um novo sistema de proteção, os tratados internacionais trazem proteção aos dispositivos que impedem as cópias, tornando ilícitas as condutas de violar os dispositivos de proteção anticópia que são agregados aos suportes materiais dos softwares, vídeos, filmes e álbuns musicais.

Não nos parece razoável que, a pretexto de proteger a propriedade imaterial, as condutas de violação dos mecanismos anticópia ou de outros mecanismos destinados exclusivamente a evitar que se compartilhe o conteúdo sem o pagamento de direitos patrimoniais de propriedade intelectual passem a ser criminalizadas.

\begin{abstract}
A escolha fica entre tentar preservar um estilo de negócio que não sobreviverá às mudanças ou tratar de encarar o problema de frente, imaginando novas soluções para as questões do mundo real. Se a lei torna todo mundo criminoso, o problema não é da sociedade. É de quem fez a lei. ${ }^{108}$
\end{abstract}

Da mesma forma, não faz mais sentido pensarmos na proteção dos direitos patrimoniais de propriedade intelectual como resguardo do próprio autor, uma vez que tanto no direito autoral quanto no direito industrial a proteção patrimonial está direcionada às empresas que controlam os meios de reprodução e distribuição das obras e dos produtos.

O direito industrial é tradicionalmente separado dos direitos de autor, como se estes últimos não se destinassem a proteger, de igual modo, interesses de empresas mercantis, ou como se no direito industrial não houvesse autoria digna de proteção. [...] Trata-se, aliás, de uma tendência muito acentuada neste tempo de mundialização da propriedade intelectual, ora com as diversas directivas comunitárias sobre propriedade intelectual, ora especialmente com o chamado Acordo TRIPs (Acordo sobre Aspectos dos Direitos de Propriedade Intelectual Relacionados com o Comércio, 1994) e que, no fundo, compreende os direitos de autor como valores de exploração mercantil das empresas da comunicação e da informação. ${ }^{109}$

107 LESSIG, Lawrence. O problema não são os piratas — é a lei. Entrevistado por Alexandre Matias e Rodrigo Martins. O Estado de São Paulo, São Paulo, 2 fev. 2009. Vida digital, p. L8.

108 DORIA, Pedro. Somos todos piratas criminosos? O Estado de São Paulo, p. L11, 23 jun. 2008.

109 PEREIRA, Alexandre Dias, 2002, p. 15-16. 
Apesar de terem origens distintas, como vimos, o direito industrial e o direito de autor hoje protegem principalmente os direitos patrimoniais de propriedade intelectual, deixando em segundo plano os direitos morais de autor, e os direitos patrimoniais, em regra, são alienados pelos autores/inventores para as empresas de comunicação, informação e indústria, que passam a usufruir exclusivamente dessa proteção dada, em tese, ao criador da obra.

\footnotetext{
O monopólio do direito de cópia (copyright), longe de tutelar os direitos do autor, é contrário ao seu interesse de maior divulgação possível da obra. O que garante aos autores a remuneração por seu trabalho não é o monopólio do direito de cópia, mas a alienação desse trabalho aos detentores dos meios de produção que irão consubstanciá-lo em meio físico e vendê-lo no livre mercado. ${ }^{110}$
}

Por esse motivo, talvez seja mais eficiente pensarmos em um modelo de proteção penal da propriedade intelectual de forma unitária, deixando a separação tradicional entre direito industrial e direito de autor para trás, para que se possa criar um sistema de tutela mais efetivo que enfrente o real problema, a pirataria.

\subsection{A PROTEÇÃo PENAL CONTRA A PIRATARIA}

Atualmente estamos recepcionando um sistema concebido com as dificuldades inerentes aos tratados internacionais, em que cada país tenta harmonizar sua legislação nacional de acordo com os interesses comerciais e políticos em jogo. A recepção das normas de proteção da propriedade intelectual homogeneizadas no direito interno cria mais distorções quando transplantadas para o direito penal e processual penal nacional.

Somado a isso, temos a nítida dificuldade de aplicar as sanções previstas aos pequenos infratores, seja pela consciência de que tais pessoas vivem em estado de pobreza, seja pela tolerância com o ilícito que viola os direitos de companhias transnacionais, seja pelo alto custo dos produtos no mercado interno, principalmente quando comparados com o salario mínimo vigente no país ${ }^{111}$.

${ }^{110}$ VIANNA, Túlio Lima, 2005, p. 15.

111 "Com efeito, a tolerância brasileira à pirataria vem gerando uma desordem pública com efeitos desanimadores: a população não reclama e incentiva a prática da pirataria como se estivesse realizando um grande negócio: compra uma mercadoria 'igual' por preço menor que o do comércio formal, o que resulta em prejuízo para ambos, comprador (por adquirir uma quinquilharia que logo sucumbe diante de 
"Uma sociedade marcada, como foi dito aqui, por uma desigualdade social muito grande e um desejo de consumo, um estímulo ao consumo também muito grande,"112 torna o ambiente propício ao produto pirateado, pois a grande maioria da população não tem acesso aos bens de consumo elaborados pelos conglomerados empresariais titulares da propriedade intelectual.

"Então, temos, talvez, hoje, de reconhecer que, por conta provavelmente da nossa formação, de nossa história, de nossa colonização, somos uma sociedade com alto grau de tolerância à ilegalidade." $" 113$

Dentro da política nacional de combate à pirataria, em respeito aos tratados internacionais dos quais o Brasil é signatário, em especial o TRIPs, foi criado o Comitê Nacional de Combate à Pirataria, do Ministério da Justiça, pelo Decreto de 13 de março de 2001, que estabeleceu seus objetivos e competências.

Dentre as competências, nos interessa ressaltar a obrigação de

[...] efetuar levantamentos estatísticos com o objetivo de estabelecer mecanismos eficazes de prevenção e repressão sobre os atos de pirataria; acompanhar novas formas de pirataria introduzidas no mercado, especialmente as realizadas em redes digitais, e propor alternativas dissuasivas de tais atos; e, propor alimentação de bancos de dados da Polícia Federal, que permita a consulta e difusão de ações realizadas no combate à pirataria, bem como o índice referente a prisões, apreensões e valores. ${ }^{114}$

Em 2002, o presidente do Comitê Nacional de Combate à Pirataria já apresentava como obstáculos para a realização de apreensões por violação de propriedade intelectual:

\footnotetext{
sua má qualidade) e comerciante estabelecido (que deixa de vender um bom produto, seu negócio entra em declínio e o maior prejudicado é seu empregado, que perde o emprego formal). O poder público, por sua vez, não se empenha na repressão por considerar tratar-se de atividade exercitada apenas por indivíduos integrantes da população menos favorecida, que, face ao desemprego, procura ganhar a vida no mercado informal, ou, pior, é neutralizado por outros meios inconfessáveis." (BRASIL. Relatório da Comissão Parlamentar de Inquérito. Finalidade: investigar fatos relacionados à pirataria de produtos industrializados e à sonegação fiscal. Brasília, 2004. Disponível em: $<$ http://www2.camara.leg.br/atividade-legislativa/comissoes/comissoes-temporarias/parlamentar-deinquerito/52-legislatura/cpipirat/relatoriofinal.pdf $>$. Acesso em: $30 \mathrm{dez} .2012$ ).

112 COLLAÇO, Rodrigo. Pirataria e lavagem de dinheiro. In: SEMINÁRIO NACIONAL DA PROPRIEDADE INDUSTRIAL, 27., 2007, Rio de Janeiro. Anais... Rio de Janeiro: ABPI, 2007. p. 49.

113 COLLAÇO, 2007, p. 49.

114 BRASIL. Decreto de 13 de março de 2001. Institui Comitê Interministerial de Combate à Pirataria, e dá outras providências. Disponível em: <http://www.planalto.gov.br/ccivil_03/dnn/2001/Dnn9147.htm>. Acesso em: 15 maio 2011.
} 
as lacunas na legislação aduaneira sobre o assunto; as incertezas na aplicação do ordenamento existente; a falta de eficácia do sistema atual; a ausência de procedimentos preestabelecidos nas alfândegas para a realização de apreensão de mercadorias contrafeitas; e a ausência de acesso, por terceiros interessados (tais como os titulares de direitos de propriedade intelectual), às operações processadas pelo Sistema Integrado de Comércio Exterior (Siscomex), por força do sigilo fiscal ${ }^{115}$.

Mais do que isso, o próprio presidente do Comitê Nacional de Combate à Pirataria do Ministério da Justiça, o delegado de Polícia Federal Clóvis da Silva Monteiro chegou a narrar, no seminário da Associação Brasileira de Propriedade Intelectual, um episódio ocorrido na porta do edifício sede da Polícia Federal que demonstra a nossa tão marcada tolerância aos delitos contra a propriedade intelectual.

\begin{abstract}
O caso: a Polícia Federal costuma, no segundo dia útil de cada mês, promover uma solenidade, em todas as unidades, central e descentralizadas, com todo o efetivo e convidados, na qual é entoado o Hino Nacional, o do DPF, além da leitura de um tema livre a cargo do setor responsável pela solenidade na ocasião. Um cidadão, coincidentemente, nesse dia ia passando e ao ver tanta gente concentrada na frente do edifício-sede da Polícia Federal, considerou ser ali um ótimo local para o seu comércio. No dia seguinte instalou um tabuleiro defronte ao edifício e iniciou a venda de seus produtos. Como o local não é próprio para tal, o chefe da segurança mandou que dois agentes fossem verificar do que se tratava. Qual não foi a surpresa dos agentes ao serem recebidos pelo cidadão que logo thes ofereceu CDs pirateados, inclusive com um "precinho" mais em conta. ${ }^{116}$
\end{abstract}

Paralelamente à incipiente atuação do Comitê Nacional de Combate à Pirataria, as associações que representam os interesses das indústrias cinematográfica, fonográfica e de software iniciaram forte campanha de combate à pirataria, focando principalmente na divulgação de dados estatísticos e nas campanhas de conscientização que associavam a imagem do camelô à do traficante de armas e drogas ${ }^{117}$.

De acordo com a ABES (Associação Brasileira de Empresas de Software), uma pesquisa da Price Water Coopers revela que, se o índice de pirataria de software brasileiro, atualmente em $56 \%$, fosse reduzido para o equivalente dos países

115 Cf. MONTEIRO, Clóvis da Silva. O fenômeno da pirataria de propriedade intelectual. In: SEMINÁRIO NACIONAL DA PROPRIEDADE INDUSTRIAL, 22., 2002, Rio de Janeiro. Anais... Rio de Janeiro: ABPI, 2002. p. 117.

116 MONTEIRO, Clóvis da Silva, 2002, p. 118.

117 A União Brasileira de Vídeo (UBV) lançou campanha com slogans agressivos contra a pirataria ("O dinheiro que circula na pirataria é o mesmo que circula no mundo do crime", "Assistir filmes em DVD falsificado não é legal, filme em DVD só original", "O dinheiro que circula na pirataria é o mesmo que circula no crime organizado" e "Comprar DVD pirata é patrocinar o crime". (UNIÃO BRASILEIRA DE VÍDEO. Campanhas UBV. Disponível em: <http://www.ubv.org.br/imprensa/campanhas>. Acesso em: 30 dez. 2012). 
desenvolvidos, em torno de $25 \%$, o setor deixaria de perder R $\$ 1,7$ bilhão em faturamento e quase $25 \mathrm{mil}$ novos empregos seriam gerados, com aproximadamente $\mathrm{R} \$ 1,2$ bilhão arrecadados em impostos diretos e indiretos. ${ }^{118}$

Fazendo frente ao discurso das associações, não faltaram vozes para desmistificar as campanhas, fortemente veiculadas nas emissoras de televisão e radiodifusão nacionais $^{119}$.

\begin{abstract}
A indústria não perde $\mathrm{R} \$ 1,7$ bilhão por ano. Este valor corresponde à sua expectativa de lucro caso quem pirateia acima da média não tivesse alternativa, nem para escolher software livre nem para instalar software pirata. A conta honesta seria outra. Desses 56\% quantos instalariam software livre ou deixariam de comprar o computador se não pudessem piratear? ${ }^{120}$
\end{abstract}

O combate à pirataria deixou o campo das ciências sociais e passou a ser uma questão política, com um frenesi de discursos contra e a favor da proteção da propriedade intelectual. "Acho que ela (pirataria) se tornará cada vez mais uma bandeira política."121

Afinal, por trás do sistema de proteção da propriedade intelectual temos questões políticas mais relevantes que o próprio combate à pirataria e a situação econômico-social daqueles que estão na ponta do iceberg. Temos as questões de desenvolvimento tecnológico, de apropriação das ideias e de transferência de tecnologia dos países desenvolvidos aos países em desenvolvimento.

\begin{abstract}
Uno de los problemas más conflictivos del mundo moderno: la transferencia de nuevas tecnologías a los países del Tercer Mundo y el régimen de comercialización de los bienes producidos gracias a esas tecnologías, lo que parece dar razón a quienes ven la estrategia planetaria de proteccionismo tecnológico como la implantación de un nuevo mercantilismo. ${ }^{122}$
\end{abstract}

Nesse contexto, a Organização Mundial da Propriedade Intelectual (WIPO, sigla do nome em inglês, World Intellectual Property Organization) passou a encampar o combate à pirataria como uma de suas bandeiras, buscando a proteção dos sistemas de controle e dos sistemas anticópia como se fossem propriedade intelectual, deixando de elaborar propostas de unificação do sistema de proteção da propriedade intelectual, atualmente fragmentado.

\footnotetext{
118 VIANNA, Túlio Lima, 2005, p. 14.

119 As primeiras campanhas lançadas pela União Brasileira de Vídeo (UBV) divulgavam o slogan "o dinheiro que circula na pirataria é o mesmo que circula no crime organizado".

120 VIANNA, Túlio Lima, 2005, p. 14.

121 LESSIG, 2009, p. L8.

122 LACKNER, Ricardo, 2002, p. 439.
} 
Outra prioridade é aumentar o papel da organização (OMPI) na luta contra a pirataria, que custa ao mundo US\$ 200 bilhões (cerca de R 358 bilhões) ao ano, e reavaliar o impacto das novas tecnologias. Esses temas são vistos como de interesse dos países ricos. Europa e EUA preferem manter apenas critérios econômicos como base para a decisão sobre direitos autorais. Para o Brasil, deve haver flexibilização em benefício de demandas educacionais. ${ }^{123}$

Neste trabalho não abordaremos as questões políticas relacionadas à transferência de tecnologia e à verticalização dos procedimentos de registro de patentes e softwares, visto que, independentemente das tensões político-internacionais, é necessária a proteção da propriedade intelectual, seja ela nacional, seja estrangeira.

Para o nosso trabalho interessa entender por que as indústrias fonográfica, cinematográfica e de software iniciaram uma campanha nacional de combate à pirataria associando os ilícitos de contrafação ao crime organizado, fomentando o governo a criar um comitê interministerial destinado a esse fim.

Ao instituir o Comitê, o governo deixou patente a todos sua firme e irreversível decisão de combater a pirataria, que nos últimos anos tem se expandido sob todas as formas, sendo já vista pelas organizações criminosas como uma modalidade delituosa de pouco risco e grande fonte de renda. ${ }^{124}$

\subsubsection{O COMBATE À PIRATARIA E A LEI DO CRIME ORGANIZADO}

As campanhas de conscientização e combate à pirataria foram lançadas no Brasil com uma abordagem extremamente agressiva, associando o camelô ao traficante de drogas e de armas. Isso não ocorreu por acaso; era necessário romper com a vitimização social da figura do ambulante, que não consegue emprego no mercado formal, e, ao mesmo tempo, associar a atividade de contrafação ao crime organizado, como forma de se utilizar das ferramentas previstas na Lei de Lavagem de Dinheiro.

A primeira dificuldade no combate à pirataria como crime organizado é que o camelô é visto pela sociedade e pelos próprios magistrados "[...] como alguém que luta contra todas as dificuldades, pela ausência de emprego formal, pela ausência de

${ }^{123}$ CHADE, Jamil; SOUZA, Nilza. País pede revisão em direito autoral. O Estado de São Paulo, p. A18, 23 set. 2008 .

${ }^{124}$ MONTEIRO, Clóvis da Silva, 2002, p. 117. 
oportunidades lícitas, luta para sobreviver e sustentar sua família. [...] Há na minha visão, quase que uma vitimização do infrator." ${ }^{\prime 125}$.

Se de um lado a ponta da cadeia de distribuição de produtos piratas é o vendedor ambulante, que é visto pela sociedade como uma pessoa sem opções no mercado formal e é socialmente tolerado ${ }^{126}$, de outro existem os detentores dos mecanismos de reprodução ilícita de filmes, álbuns musicais, softwares e produtos de marcas conhecidas, que controlam uma cadeia de produção e distribuição de produtos piratas presente em inúmeros países.

Para enfrentar esse tipo de criminalidade, não basta prender e processar os pequenos ambulantes que trabalham nas ruas ou em pequenos quiosques de centros comerciais das grandes cidades. É imprescindível atacar os distribuidores e os locais de reprodução ilícita de tais produtos, atingindo de forma mais eficiente os reais responsáveis pela pirataria de produtos.

\begin{abstract}
A pirataria, hoje, segundo a Interpol, é o crime mais rentável do mundo ou, pelo menos, o segundo mais rentável do mundo. E sendo tão rentável assim, evidentemente que não é praticado por uma, duas ou três pessoas; são crimes praticados por verdadeiras organizações criminosas, com ramificação internacional, as máfias russa, coreana, etc., etc. ${ }^{127}$
\end{abstract}

Não estamos aqui legitimando a ideia (ou concordando com ela) de que as organizações criminosas que controlam o tráfico de armas e o tráfico de entorpecentes sejam as mesmas que controlam a produção e a distribuição de produtos piratas, mas não podemos negar que existam estruturas organizadas que controlam essa atividade criminosa que hoje tem proporções transnacionais.

Exatamente pela alta lucratividade e pelo baixo risco que a atividade apresenta, as organizações criminosas já se apropriaram de todas as fases da cadeia produtiva de itens contrafeitos, desde a produção até a distribuição nos grandes centros urbanos ${ }^{128}$, inclusive

125 COLLAÇO, Rodrigo, 2007, p. 49-50.

126 Vide: GONÇALVES, Marcel Figueiredo. Vendedor ambulante, contrafação de mídias e acumulação. Boletim IBCCrim, São Paulo, n. 209, v. 17, p. 6-7, 2010, p. 7.

127 DIPP, Gilson. Pirataria e lavagem de dinheiro. In: SEMINÁRIO NACIONAL DA PROPRIEDADE INDUSTRIAL, 27., 2007, Rio de Janeiro. Anais... Rio de Janeiro: ABPI, 2007. p. 40.

128 “A bolsa Prada, que a desembargadora Maria Helena tanto gosta, para ser colocada no mercado a preço acessível, é preciso que alguém vá a Milão e roube o desenho da bolsa, como todos os seus apetrechos, acessórios etc., que vocês conhecem melhor do que eu. É preciso que alguém remeta esse desenho, essa 
comprovadamente utilizando imigrantes ilegais como mão de obra para a venda desses produtos contrafeitos em diversos países da Europa.

Por esse motivo, uma vez constatado que a pirataria é uma atividade de organizações criminosas, o Brasil passou a desenvolver um setor de inteligência para combater a entrada dos produtos contrafeitos no país e aparelhar a Polícia Federal e a Receita Federal de informações e equipamentos necessários ao combate das quadrilhas, e não dos vendedores ambulantes espalhados nos grandes centros.

"O trabalho do Conselho em seu primeiro biênio de funcionamento [...] justamente visava buscar enfrentar essas quadrilhas, não pelas suas linhas mais fracas, que eram as pontas, o camelô, e sim pelas redes de produção e distribuição dos produtos piratas." "129

Da mesma forma tornou-se necessária a repressão interna das quadrilhas, visto que as atividades coordenadas pelo Comitê Nacional de Combate à Pirataria ${ }^{130}$ nas fronteiras com a Polícia Federal e a Receita Federal não conseguiriam impedir nem a entrada, no mercado interno, de produtos contrafeitos, nem a própria produção interna destes.

\footnotetext{
Elaboram sofisticados sistemas de internalização de produtos falsos e ilegais nessa região, formando uma poderosa rede de distribuição, que leva essa produção a estados, a municípios, a depósitos nas capitais e, depois, a pequenos depósitos. Criou-se uma rede de vans e veículos que distribuem essa mercadoria até que ela chegue na ponta, onde existe um camelô. ${ }^{131}$
}

Todavia, a identificação da atividade de pirataria como uma atividade de organização criminosa não tinha o objetivo de fazer com que o governo federal unisse esforços no combate das quadrilhas nas fronteiras e no mercado interno, mas sim de atacar

matriz para a China, por exemplo. Na China, é preciso que haja uma outra organização, que possibilite a compra do material adequado para a feitura, a produção dessa bolsa. E é preciso uma outra grande organização, muitas vezes separada, que faça a distribuição desse produto para o mundo inteiro. E aí chegue na ponta do camelô.” DIPP, Gilson, 2007, p. 41.

129 BARRETO, Luiz Paulo. Pirataria e lavagem de dinheiro. In: SEMINÁRIO NACIONAL DA PROPRIEDADE INDUSTRIAL, 27., 2007, Rio de Janeiro. Anais... Rio de Janeiro: ABPI, 2007. p. 45.

${ }^{130} \mathrm{O}$ Comitê Nacional de Combate à Pirataria foi substituído pelo Conselho Nacional de Combate à Pirataria e Delitos contra a Propriedade Intelectual por força do Decreto $n^{\circ} 5.244 / 2004$ (BRASIL. Decreto $n^{\circ} 5.244$ de 14 de outubro de 2004. Dispõe sobre a composição e funcionamento do Conselho Nacional de Combate à Pirataria e Delitos contra a Propriedade Intelectual, e dá outras providências. Disponível em: $<$ http://www.planalto.gov.br/ccivil_03/_Ato2004-2006/2004/Decreto/D5244.htm\#art11>. Acesso em: 22 jun. 2011).

131 BARRETO, Luiz Paulo, 2007, p. 43. 
as quadrilhas com os instrumentos previstos na Lei de Lavagem de Dinheiro, como medida eficaz para desmantelar as organizações criminosas.

Poderia se dizer que todos os problemas relacionados à proteção à propriedade intelectual (do combate ao delito, do combate à pirataria e ao crime organizado dela decorrente, aí incluindo a lavagem de dinheiro) decorrem dessa intrincada relação econômica do mundo moderno, do mundo globalizado. ${ }^{132}$

Antes de analisarmos os instrumentos da Lei de Lavagem de Dinheiro é importante ressaltar que, até 2012, era necessário caracterizar a atividade de pirataria como crime organizado para que fosse lícito o uso dos mecanismos previstos para a lavagem de dinheiro, uma vez que a referida norma apresentava um rol taxativo de crimes aos quais se aplicava.

Por esse motivo, se forçou o enquadramento da atividade de pirataria como atividade praticada por organizações criminosas, que não foram definidas pela Lei $\mathrm{n}^{0}$ 9.034/1995 mas que encontram definição no ordenamento jurídico brasileiro com a recepção da Convenção de Palermo pelo Decreto n ${ }^{0}$ 5.015/2004.

Segundo a definição da Convenção das Nações Unidas contra o Crime Organizado Transnacional, organização criminosa é o

[...] grupo estruturado de três ou mais pessoas, existente há algum tempo e atuando concertadamente com o propósito de cometer uma ou mais infrações graves ou enunciadas na presente Convenção, com a intenção de obter, direta ou indiretamente, um benefício econômico ou outro benefício material. ${ }^{133}$

O professor Antonio Scarance Fernandes, analisando o trabalho de diversos autores que definiram o conceito de organização criminosa, apontou os elementos fundamentais:

[...] associação permanente e estável de diversas pessoas; estruturação empresarial, hierarquizada e piramidal, com poder concentrado nas mãos dos líderes, os quais não mantêm contato diretamente com as bases; poder elevado de corrupção; uso de violência e de intimidação para submeter os membros da organização e para obter a colaboração ou o silêncio de pessoas nãoparticipantes do núcleo criminoso; finalidade de lucro; uso de sistemas de lavagem de dinheiro para legalizar as vultuosas somas obtidas com as práticas

132 DIPP, Gilson, 2007, p. 39.

133 “Artigo 2. Terminologia. Para efeitos da presente Convenção, entende-se por: a) 'Grupo criminoso organizado' - grupo estruturado de três ou mais pessoas, existente há algum tempo e atuando concertadamente com o propósito de cometer uma ou mais infrações graves ou enunciadas na presente Convenção, com a intenção de obter, direta ou indiretamente, um benefício econômico ou outro benefício material;" 
delituosas; regionalização ou internacionalização da organização; o uso de modernas tecnologias. ${ }^{134}$

Se tomarmos a definição legal mais estreita, prevista na Convenção das Nações Unidas contra o Crime Organizado Transnacional, poderíamos enquadrar como organizações criminosas aquelas dedicadas à pirataria de filmes, álbuns musicais e softwares, que seriam, para efeito daquela convenção, infrações penais graves, uma vez que as infrações são consideradas graves, pelo texto da convenção, quando impõem pena máxima não inferior a quatro anos ${ }^{135}$.

Entretanto, a contrafação de produtos tais como bolsas, tênis, sapatos, relógios, brinquedos, hardwares e outros bens de consumo não se enquadraria na definição de infrações graves da própria convenção, observadas as penas máximas aplicadas às infrações contra a propriedade industrial. Uma vez que a pirataria de bens de consumo é muito mais sofisticada que a de filmes, álbuns musicais e softwares, seja pela dificuldade de reprodução, seja pela complexidade na elaboração e na distribuição das cópias contrafeitas, entendemos que há uma distorção injustificada no sistema.

\subsubsection{O COMBATE À PIRATARIA E A LEI DOS CRIMES DE LAVAGEM DE DINHEIRO}

O ex-ministro da Justiça Luiz Paulo Barreto, quando ocupava o cargo de presidente do Conselho Nacional de Combate à Pirataria, chegou a divulgar que

[...] a pirataria é o delito do século XXI. [...] Hoje, a pirataria é o delito que mais movimenta recursos, ou seja, US\$ 522 bilhões/ano, contra US\$ 360 bilhões/ano movimentados pelo narcotráfico, despontando como um crime de ponta no cenário internacional. [...] A pirataria inibe investimentos externos e afeta o mercado de trabalho. [...] Causa prejuízo à indústria nacional. [...] A pirataria também compromete a arrecadação tributária, onde se perdem recursos da ordem de R\$ 30 bilhões por ano, segundo o Unafisco [União dos Auditores Fiscais da Receita Federal do Brasil]. ${ }^{136}$

${ }^{134}$ FERNANDES, Antonio Scarance. O equilíbrio na repressão ao crime organizado. In: FERNANDES, Antonio Scarance; ALMEIDA, José Raul Gavião de; MORAES, Maurício Zanoide de. (Orgs.). Crime organizado: aspectos processuais. São Paulo: Revista dos Tribunais, 2009. p. 9-28. p. 12-13.

135 “Artigo 2. Terminologia. Para efeitos da presente Convenção, entende-se por: [...] b) 'Infração grave' ato que constitua infração punível com uma pena de privação de liberdade, cujo máximo não seja inferior a quatro anos ou com pena superior;"

136 BARRETO, Luiz Paulo, 2007, p. 44. 
A associação da atividade de pirataria às atividades de organização criminosa tinha como escopo exatamente desenvolver o conceito de que a primeira precisava ser combatida com mecanismos que atacassem o poderio financeiro das organizações criminosas que atuam no setor, visto que a repressão aos pequenos vendedores de produtos piratas se mostra absolutamente ineficaz ao combate à pirataria.

A primeira dificuldade enfrentada é a falta de definição do conceito de organização criminosa na Lei $n^{0}$ 9.034/1995, destinada à prevenção e à repressão de ações praticadas por organizações criminosas. Para tal, como mencionamos no item anterior, se buscou o conceito de organização criminosa previsto na Convenção de Palermo, recepcionada no direito interno pelo Decreto $n^{0} 5.015 / 04$, que define organização criminosa em seu artigo $2^{\circ}$.

\begin{abstract}
A chamada Convenção de Palermo traz com todas as letras o conceito universal de crime organizado ou de organização criminosa, conceito esse que atende aos reclamos da nossa doutrina, porque são exatamente aquelas características que referi a vocês há pouco: concentração de três ou mais pessoas visando o lucro em atividades e praticando crimes graves, que visem o lucro. ${ }^{137}$
\end{abstract}

Criou-se também uma presunção de que a pirataria estava intimamente ligada à corrupção de agentes públicos — seja na produção, seja na distribuição, seja na própria venda dos produtos —, sem se identificar com dados empíricos os meios pelos quais as quadrilhas que controlam a pirataria se utilizam da corrupção para a consecução de suas atividades.

\footnotetext{
A pirataria é um crime praticado por organização criminosa, prevista na Lei de Lavagem de Dinheiro. E não há organização criminosa, não há crime organizado que se mantenha com aquelas características de três ou mais pessoas, com divisão de tarefas, com caráter mais ou menos empresarial, com uma certa hierarquia, que visa o lucro e que não tenha intimamente, não esteja intimamente ligado com um agente público ou um agente político. ${ }^{138}$
}

Dessa forma, os crimes contra a propriedade imaterial - que não eram crimes antecedentes ao crime de lavagem de dinheiro e, portanto, não era permitida, em relação a eles, a utilização de medidas de apreensão ou de sequestro de bens, direitos ou valores em nome dos acusados, na forma do artigo $4^{\circ}$ da Lei $n^{0} 9.613 / 1998$ - passaram a ser conceituados como crimes praticados por organizações criminosas.

\footnotetext{
137 DIPP, Gilson, 2007, p. 42.

138 DIPP, Gilson, 2007, p. 42.
} 
Entretanto, os efeitos de tal sistematização ainda são incipientes, pois não há nenhum precedente, nos tribunais superiores, de condenação por crimes de lavagem de dinheiro relacionados à pirataria. "Soube que houve uma perplexidade meio generalizada em relação à inexistência de condenações a respeito de crimes de lavagem de dinheiro, a respeito de pirataria." $" 139$

Em julho de 2012 a Lei de Lavagem de Dinheiro foi alterada pela Lei $\mathrm{n}^{\mathrm{o}}$ $12.683 / 2012^{140}$, que revogou o rol taxativo de crimes aos quais ela poderia ser aplicada, estendendo os mecanismos de repressão da Lei de Lavagem de Dinheiro para todas as infrações penais indiscriminadamente. Ao mesmo tempo que a mudança permite a aplicação da norma aos casos de pirataria de produtos, nos parece que a abrangência ilimitada a todas as infrações penais é excessiva e desproporcional.

A utilização da Lei de Lavagem de Dinheiro no combate à pirataria é medida que pode se mostrar eficaz no efetivo desmantelamento das organizações que controlam a contrafação de produtos, não pela imputação de mais um crime previsto na própria norma, mas pelas medidas assecuratórias de bens previstas no artigo $4^{\circ}$ da Lei $n^{\circ} 9.613 / 1998$, que atacam diretamente o poderio financeiro das organizações dedicadas a tal fim ${ }^{141}$.

Parece-nos que os esforços de associar a pirataria com as organizações criminosas não é o problema a ser enfrentado no sistema processual penal brasileiro, visto que as alterações introduzidas pelas Leis $n^{0} 12.683 / 2012$ e 10.695/2003 seriam mais eficazes se houvesse uma sistematização da proteção penal conferida à propriedade intelectual, unificando os regimes de direito de autor, direito de autor de programa de computador e de direito industrial.

${ }^{139}$ BARRETO, Luiz Paulo, 2007, p. 49.

${ }^{140}$ BRASIL. Lei $n^{\circ} 12.683$, de 9 de julho de 2012. Altera a Lei no 9.613, de 3 de março de 1998, para tornar mais eficiente a persecução penal dos crimes de lavagem de dinheiro. Disponível em: $<$ http://www.planalto.gov.br/ccivil_03/_Ato2011-2014/2012/Lei/L12683.htm). Acesso em: 17 dez. 2012.

${ }^{141}$ Cumpre destacar que o parágrafo $2^{\circ}$ do artigo $4^{\circ}$ da Lei $n^{\circ} 9.613 / 1998$ estabelece que a liberação total ou parcial de bens, direitos e valores só poderá ocorrer quando for comprovada a licitude de sua origem, invertendo o ônus da prova em desfavor do acusado. Segundo o professor Scarance, “[...] é aceitável o condicionamento da liberação dos bens apreendidos à produção de prova, pelo acusado, de sua origem legal, pois o processo serve exatamente para o Ministério Público demonstrar a culpabilidade do acusado e a origem ilícita dos bens apreendidos. O problema maior está na perda dos bens após a condenação, sem prova segura de que foram adquiridos com proventos auferidos da atividade criminosa." (FERNANDES, Antonio Scarance, 2009, p. 21). 
"Não há um sistema unitário e homogêneo ao nível do crime contra a propriedade intelectual. Existem apenas diversos tipos legais de crime que reforçam a proteção de certos direitos de propriedade intelectual." ${ }^{, 142}$

Como veremos, a proteção penal da propriedade intelectual se subdivide em crimes de violação de direitos autorais, crimes de violação de direitos de autor de software e crimes contra a propriedade industrial. Os crimes de violação de direitos autorais estão previstos no Decreto-Lei $\mathrm{n}^{\circ} 2.848$, de 7 de dezembro de 1940, o Código Penal, os crimes de violação de direitos de autor de software estão previstos na Lei $n^{\circ} 9.609 / 1998$ e os crimes contra a propriedade industrial estão disciplinados pela Lei ${ }^{\circ}$ 9.279/1996.

\subsection{VIOLAÇÃO DE DIREITO AUTORAL}

O artigo 184, caput, do Código Penal tipifica a conduta de violação de direitos de autor e de direitos conexos aos direitos de autor, abrangendo os direitos de artistas intérpretes ou executantes, os dos produtores fonográficos e os das empresas de radiodifusão.

Inicialmente, cumpre observar que o tipo penal cuja redação foi modificada pela Lei $n^{0} 10.695 / 2003$ estendeu a proteção penal para os direitos de artistas executantes, produtores fonográficos e empresas de radiodifusão, uma vez que foram acrescidos os direitos conexos aos direitos de autor, já disciplinados na Lei n ${ }^{\circ}$ 9.610/1998.

“A redação atual, dada pela Lei 10.695/2003, ao mencionar expressamente 'direito de autor e os que lhes são conexos', resolve em definitivo a questão, tornando inconteste a tutela penal sobre ambas as espécies de direitos autorais."143

As modificações introduzidas ao tipo penal não foram totalmente negativas, como veremos mais à frente, entretanto não solucionaram a falta de taxatividade dessa norma

142 PEREIRA, Alexandre Dias, 2002, p. 25.

143 VANZOLINI, Maria Patricia. Crimes contra a propriedade imaterial: comentários às alterações do código penal e do código de processo penal. In: GOMES, Luiz Flávio; VANZOLINI, Maria Patricia. Reforma criminal. São Paulo: Revista dos Tribunais, 2004. p. 43-90. p. 48. 
penal em branco, que remete para um diploma legal complexo que sistematiza toda a proteção dos direitos de autor ${ }^{144}$.

\section{Segundo a professora Janaina Conceição Paschoal,}

O artigo 184, caput, do Código Penal, criminaliza, genericamente, a violação dos direitos autorais e conexos, constituindo, por isso, exemplo de norma penal em branco, cuja amplitude chega a afrontar a taxatividade (pressuposto da legalidade), pois a lei que disciplina a proteção dos direitos autorais, Lei $\mathrm{n}^{\circ}$ $9.610 / 98$, conta com quase 200 artigos. $^{145}$

Sobre a mesma problemática superada pela reforma penal espanhola de 1995, Ricardo Lackner escreveu que

Lo anterior, unido a su estructura de ley penal en blanco, determinaban que el delito así establecido lesionara las garantías derivadas del principio de legalidad. [...] El artículo 273 del código penal español (ya transcripto en nota ${ }^{[146]}$ ) abandonó la estructura de ley penal en blanco incorporando una serie de verbos nucleares, haciendo posible deducir el contenido injusto, lo cual significó un avance importante que supo destacar la doctrina. ${ }^{147}$

Aqui, cabe observar que a forma como o legislador criminalizou a violação dos direitos de autor suscita duas discussões sobre o tipo penal, pois sob esse rótulo existem os direitos morais de autor e os direitos patrimoniais de autor.

Os direitos morais de autor consistem no direito de: reivindicar a autoria da obra; ter seu nome, pseudônimo ou sinal convencional indicado ou anunciado como sendo o do autor, na utilização de sua obra; conservar a obra inédita; assegurar a integridade da obra, opondo-se a quaisquer modificações; modificar a obra, antes ou depois de utilizada; retirar de circulação a obra ou suspender qualquer forma de utilização já autorizada, quando a circulação ou a utilização implicarem afronta à sua reputação e à sua imagem; e ter acesso a exemplar único e raro da obra para reprodução.

144 "Trata-se de verdadeira norma penal em branco, a regra insculpida no artigo sub examine busca complementação na seara civil: é a Lei 9.610/98 que se encontra a definição de direitos autorais." (VANZOLINI, Maria Patricia, 2004, p. 45.).

145 PASCHOAL, Janaina Conceição. Tudo em nome dos direitos autorais. Boletim IBCCrim, São Paulo, $\mathrm{n}$. 149, v. 12, p. 16-17, 2005. p.16.

146 “Artículo 273.1. - Será castigado con las penas de prisión de seis meses a dos años y multa de seis a veinticuatro meses el que, con fines industriales o comerciales, sin consentimiento del titular de una patente o modelo de utilidad y con conocimiento de su registro, fabrique, importe, posea, utilice, ofrezca o introduzca en el comercio objetos amparados por tales derechos. Articulo 273.2. - Las mismas penas se impondrán al que, de igual manera, y para los citados fines, utilice u ofrezca la utilización, introduzca en el comercio, o utilice el producto directamente obtenido por el procedimiento patentado."

147 LACKNER, Ricardo, 2002, p. 440. 
Já os direitos patrimoniais de autor consistem no direito exclusivo de utilizar-se, fruir e dispor da obra literária, artística ou científica. Dependem de autorização prévia e expressa do autor: a reprodução parcial ou integral; a edição; a adaptação, o arranjo musical e quaisquer outras transformações; a tradução para qualquer idioma; a inclusão em fonograma ou produção audiovisual; a distribuição, quando não intrínseca ao contrato firmado pelo autor com terceiros para uso ou exploração da obra; a distribuição para oferta de obras ou produções mediante cabo, fibra ótica, satélite, ondas ou qualquer outro sistema; a utilização, direta ou indireta, da obra; a inclusão em base de dados, o armazenamento em computador, a microfilmagem e as demais formas de arquivamento do gênero; quaisquer outras modalidades de utilização existentes ou que venham a ser inventadas.

"Trata-se, portanto, de um tipo penal complexo que tutela não um, mas inúmeros bens jurídicos de natureza moral e patrimonial, agrupados sob a ideologia da 'propriedade intelectual'." 148

Dessa forma, a primeira discussão sobre a tipificação da conduta de violação de direitos de autor e conexos é que a conduta prevista é excessivamente genérica e, por tal motivo, padeceria de vício de inconstitucionalidade pela ausência de taxatividade necessária.

A segunda discussão refere-se à proteção patrimonial dos direitos de autor, a qual, segundo Túlio Vianna, violaria os princípios da intervenção penal mínima e da vedação constitucional às prisões por dívidas ${ }^{149}$. Parece-nos um tanto exagerada a posição de Túlio Vianna, que prega a completa descriminalização das violações de direitos autorais, entretanto temos de concordar com a afirmação de que a norma insculpida no caput do artigo 184 do Código Penal viola o princípio da legalidade, porque não descreve as condutas proibidas.

\footnotetext{
148 VIANNA, Túlio Lima. A inconstitucionalidade da criminalização da pirataria. MPMG Jurídico, Belo Horizonte, v. 2, n. 7, p. 52-53, out./dez., 2006. p. 52.

149 VIANNA, Túlio Lima, 2006, p. 52.
} 
Os parágrafos $1^{\circ}$ e $2^{\circ}$ do artigo 184 do Código Penal, introduzidos pela Lei $n^{0}$ 10.695/2003, trouxeram as vedações às condutas destinadas a coibir a pirataria de livros, CDs e DVDs. Segundo o parágrafo $1^{\circ}$, fica vedada a reprodução total ou parcial, com intuito de lucro direto ou indireto, por qualquer meio ou processo, de obra intelectual, interpretação, execução ou fonograma, sem autorização ${ }^{150}$.

Já o parágrafo segundo veda as condutas acessórias à reprodução — distribuir, vender, expor à venda, alugar, introduzir no país, adquirir, ocultar, ter em depósito, com intuito de lucro direto ou indireto, original ou cópia de obra intelectual ou fonograma reproduzido com violação do direito de autor ou conexo - e a conduta de alugar original ou cópia de obra intelectual ou fonograma, sem a expressa autorização ${ }^{151}$.

Ambos os parágrafos têm o objetivo claro e cristalino de proteger da pirataria os direitos patrimoniais de autor, principalmente o copyright, atendendo aos interesses da indústria fonográfica e cinematográfica, além dos interesses do governo, que se beneficia da arrecadação direta e indireta de impostos.

O parágrafo $3^{\circ}$ trouxe uma inovação, tipificando as condutas de oferecimento do produto ao público, com intuito de lucro, direto ou indireto, sem autorização, mediante cabo, fibra ótica, satélite, ondas ou qualquer outro sistema que permita ao usuário selecionar a obra ou a produção para recebê-la em tempo e lugar previamente determinados por quem formula a demanda.

A vedação a essas condutas tem como objetivo o combate à pirataria digital, principalmente a praticada dentro da rede mundial de computadores, cujo controle torna-se cada dia mais difícil diante do desenvolvimento de novas tecnologias que permitem ao usuário obter cópias de livros, músicas e filmes de diversos outros usuários copiando pequenos fragmentos de cada um ao mesmo tempo ${ }^{152}$.

\footnotetext{
150 VANZOLINI, Maria Patricia, 2004, p 62.

151 Sobre a autorização expressa: "Trata-se de elemento normativo do tipo a demandar, para sua verificação, um juízo de valor no campo da atipicidade. É indispensável, portanto, para configurar-se o delito, o dissenso do autor ou de seus herdeiros e sucessores. Autorizada a reprodução, a conduta é atípica." (VANZOLINI, Maria Patricia, 2004, p. 63.).

$152 \mathrm{O}$ download fragmentado é obtido por meio de torrents mencionados no capítulo anterior.
} 


\section{Para Guilherme Carboni,}

[...] a tônica da Lei 10.695/03 é penalizar, principalmente, a prática que tenha intuito de lucro direto ou indireto, conforme expressamente estabelecem os parágrafos $1^{\circ}, 2^{\circ}$ e $3^{\circ}$ desse mesmo artigo. Para esses casos, o legislador aumentou a pena, com o claro intuito de combater a prática da pirataria de obras protegidas por direitos autorais, inclusive nas novas tecnologias, como a internet, cujo tipo penal foi definido no parágrafo $3^{\circ}$, do artigo $184 .^{153}$

O principal ponto positivo das alterações trazidas pela Lei $n^{0} 10.695 / 2003$ foi a redação do parágrafo $4^{\circ}$, que, além de reforçar a ideia de que os casos de exceção ou limitação aos direitos de autor previstos na Lei no 9.610/1998 são causas excludentes da ilicitude, derrogou, por consequência lógica, o inciso II do artigo 46 do mesmo diploma legal.

Isso significa dizer que as limitações aos direitos de autor previstas no inciso II do artigo 46 da Lei no 9.610/1998 foram ampliadas, inclusive para a esfera cível, pois, se a Lei de Direitos Autorais estabelece que não constitui ofensa aos direitos autorais a cópia de pequenos trechos, desde que para uso privado do copista e sem intenção de lucro, a redação do parágrafo $4^{\circ}$ (norma posterior) estabeleceu que não se aplicam as proibições previstas para o copista que realizar cópia única, para uso privado, sem intenção de lucro $^{154}$.

\section{Segundo Janaina Conceição Paschoal,}

[...] o artigo $184, \S 4^{\circ}$, do Código Penal, tornou atípico o ato de copiar obra intelectual, em um único exemplar, para uso privado, sem intuito de lucro direto ou indireto, sendo forçoso concluir ter restado igualmente, atípica, a ação de quem presta esse serviço ao particular. Aliás, o próprio $\S 4^{\circ}$ afirma aplicar-se tal atipicidade aos $\S \S 2^{\circ}$ e $3^{\circ}$ do mesmo artigo 184 do Código Penal, os quais criminalizam, justamente, a reprodução de obra intelectual com intuito de lucro. $^{155}$

Por outro lado, existem autores que defendem que, apesar de a nova redação do parágrafo $4^{\circ}$ do artigo 184 tornar atípica a cópia de obra intelectual em um único exemplar

153 CARBONI, Guilherme C. A lei 10.695/03 e seu impacto no direito autoral brasileiro. Jus Navigandi, Separata F 63, p. 3, ago. 2003. Disponível em: <http://jus.com.br/revista/texto/4432/a-lei-no-10-695-03e-seu-impacto-no-direito-autoral-brasileiro >. Acesso em: 3 dez. 2012.

154 “ $\S 4^{\circ}$. O disposto nos $\S \S 1^{\circ}, 2^{\circ}$ e $3^{\circ}$ não se aplica quando se tratar de exceção ou limitação ao direito de autor ou os que lhe são conexos, em conformidade com o previsto na Lei $\mathrm{n}^{\circ}$ 9.610, de 19 de fevereiro de 1998, nem a cópia de obra intelectual ou fonograma, em um só exemplar, para uso privado do copista, sem intuito de lucro direto ou indireto".

155 PASCHOAL, Janaina Conceição, 2005, p. 17. 
para uso privado sem intuito de lucro direto ou indireto, permanecem vigentes as disposições do inciso II do artigo 46 da Lei $n^{0}$ 9.610/1998, que limitam as cópias a pequenos trechos, o que permitiria ao titular dos direitos autorais ingressar com ação cível com a finalidade de apreender as obras reproduzidas ou de suspender a prática ${ }^{156}$.

Em uma terceira corrente, Maria Patricia Vanzolini chega a defender que "[ $[.$.$] a$ redação do art. $4^{0}[\ldots]$ revela falta de técnica legislativa, ao conduzir uma interpretação absolutamente não desejada pelo legislador." ${ }^{\text {,157. }}$

Aqui não nos parece a interpretação mais adequada, pois limitar a causa excludente de ilicitude ${ }^{158}$ prevista no parágrafo $4^{\circ}$ do artigo 184 do Código Penal apenas aos aspectos penais da conduta permitiria que o titular dos direitos de autor tomasse medidas tão gravosas quanto as medidas penais excluídas pelo próprio parágrafo $4^{\circ}$, que modificou o sistema e resolveu o problema das cópias com finalidades científicas e educacionais originadas do parco acervo das bibliotecas das instituições de ensino brasileiras.

Por fim, é importante ressaltar que o artigo 186 do Código Penal estabelece que os crimes previstos no caput do artigo 184 são crimes de ação penal privada ${ }^{159}$, enquanto os crimes previstos nos parágrafos do mesmo artigo são crimes de ação penal pública.

156 Nesse sentido: "No entanto, apesar de a Lei 10.695/03 ter expressamente excluído da tipificação penal a reprodução privada da obra para uso particular do copista, em um único exemplar, sem intuito de lucro, o fato é que continua em vigor a regra do artigo 46, inciso II, da Lei de Direitos Autorais. Portanto, o titular dos direitos autorais ainda pode ingressar com uma ação na esfera cível, visando a apreensão das obras reproduzidas ou a suspensão da prática, além do pagamento de uma indenização pela reprodução integral não autorizada." (CARBONI, Guilherme C., 2003, p. 3).

157 VANZOLINI, Maria Patricia, 2004, p. 88.

158 Para Maria Patricia Vanzolini, não se trata de causa excludente de ilicitude, mas da própria tipicidade da conduta: "Entendemos serem causas de exclusão da própria tipicidade da conduta. É que, como já aludido, o direito de autor não é ilimitado. Todo direito se desenvolve em certa esfera, marcada por lei por regras positivas ou negativas. Estas regras negativas são elementos constitutivos da atribuição em que o direito de autor se cifra, tanto como as regras positivas. Dessa forma, nos casos previstos não há, na verdade, nenhum direito autoral protegido e, portanto, nenhum pode ser violado." (VANZOLINI, Maria Patricia, 2004, p. 76.).

159 Exceto os crimes cometidos em desfavor de entidades de direito público, autarquias, empresas públicas, sociedades de economia mista ou fundações instituídas pelo poder público. 


\subsection{VIOLAÇÃO DE DIREITOS DE AUTOR DE SOFTWARE}

A Lei $n^{0} 9.609 / 1998$, que dispõe sobre a propriedade intelectual de programa de computador, optou por equiparar a proteção da propriedade intelectual de tais criações ao direito de autor, por razões óbvias: 1) a ausência de necessidade de registro e concessão de patente (sujeita a critérios de novidade, atividade inventiva e aplicação industrial); 2) limite temporal mais extenso ${ }^{160}$.

Como reflexo, a própria Lei $n^{0} 9.609 / 1998$ estabeleceu, em seu artigo 12, proteção penal específica, utilizando a mesma fórmula genérica do artigo 184 do Código Penal. Segundo o mencionado dispositivo, constitui crime contra os direitos de autor de software a violação de quaisquer direitos previstos na referida norma e na Lei ${ }^{0} 9.610 / 1998$, que se aplica subsidiariamente aos direitos de autor de programa de computador ${ }^{161}$.

A semelhança dos tipos penais permite concluir que a tipificação utilizada pela Lei $n^{\circ}$ 9.609/1998 serviu de inspiração para as reformas introduzidas pela Lei $n^{0} 10.695 / 2003$ ao artigo 184 do Código Penal, trazendo, com o claro objetivo de combater a pirataria de programas de computador, novas condutas ao sistema .

Nesse sentido, o caput do artigo 12 da Lei $\mathrm{n}^{\circ}$ 9.609/1998 é complementado por dois parágrafos: o primeiro estabelece penas mais graves para a reprodução, por qualquer meio, de programa de computador, no todo ou em parte, para fins de comércio, sem autorização expressa do autor; o segundo tipifica as condutas acessórias à reprodução — vender, expor à venda, introduzir no país, adquirir, ocultar ou ter em depósito, para fins de comércio, original ou cópia de programa de computador produzido com violação de direito autoral.

Não existe uma previsão específica para crimes cometidos por meio da rede mundial de computadores, como a previsão estabelecida no parágrafo $3^{\circ}$ do artigo 184 do Código Penal. Isso talvez ocorra porque, à época, a velocidade e a dificuldade de acesso não permitiam a reprodução de programas de computador pela internet, cujo tamanho era incompatível com a velocidade de download e upload.

\footnotetext{
${ }^{160}$ Cf. SANTOS, Manoel J. Pereira dos. A nova lei do software: aspectos controvertidos da proteção autoral. Revista da ABPI, Rio de Janeiro, n. 29, p. 21-28, 1997, p. 22.

161 Cf. SILVEIRA, Newton, 2011, p. 68.
} 
Por fim, o parágrafo terceiro do artigo 12 da Lei $\mathrm{n}^{0}$ 9.609/1998 estabelece que os crimes previstos são crimes de ação penal privada, salvo quando praticados em prejuízo de entidade de direito público, autarquia, empresa pública, sociedade de economia mista ou fundação instituída pelo poder público ou quando do ato delituoso resultar sonegação fiscal, perda de arrecadação tributária ou prática de quaisquer dos crimes contra a ordem tributária ou contra as relações de consumo ${ }^{162}$.

Esse parágrafo traz uma linha divisória muito importante, pois, apesar, de visivelmente inspirado no discurso da indústria de software, isola de forma sutil a pirataria dos demais crimes de violação de direitos de autor de software. A fórmula criativamente utilizada consistiu em separar dos demais crimes aqueles em que exista sonegação fiscal ou perda de arrecadação tributária, disciplinando-os como crimes de ação penal pública.

\subsection{CRIMES CONTRA A PROPRIEDADE INDUSTRIAL}

Os crimes contra a propriedade industrial estão previstos na Lei $n^{0}$ 9.279/1996 e se subdividem em: crimes contra as patentes; crimes contra os desenhos industriais; crimes contra as marcas; crimes cometidos por meio de marca, título de estabelecimento e sinal de propaganda; crimes contra indicações geográficas e demais indicações; e crimes de concorrência desleal.

Os crimes contra as patentes estão previstos nos artigos 183, 184 e 185 da Lei $n^{\circ}$ 9.279/1996 e protegem as patentes de invenção e as de modelo de utilidade, bem como os componentes, o material e os equipamentos necessários à realização de qualquer processo patenteado.

Sem a autorização do titular, são vedadas as condutas de fabricar produto patenteado ou usar meio ou processo que seja objeto de patente ${ }^{163}$, além das atividades secundárias à reprodução - exportar, vender, expor ou oferecer à venda, ter em estoque,

${ }^{162}$ Cf. MURTA FILHO, Antonio, Aspectos penais inovadores da recente lei 9.609, de 19/2/98. Revista da ABPI, Rio de Janeiro, n. 29, p. 29-33, 1997, p. 32.

${ }^{163}$ Cf. PIERANGELI, José Henrique. Crimes contra a propriedade industrial e crimes de concorrência desleal. São Paulo: Revista dos Tribunais, 2003. p. 189. 
ocultar ou receber para utilização com fins econômicos produto fabricado mediante a violação de patente de invenção ou de modelo de utilidade ou obtido por meio ou processo patenteado $^{164}$.

Como reflexo do próprio sistema de proteção da propriedade industrial, também foi vedada a conduta de importar, para fins econômicos, produto que 1) seja objeto de patente de invenção ou de modelo de utilidade ou que seja obtido por meio ou processo patenteado no país e que 2) não tenha sido colocado no mercado externo diretamente pelo titular da patente ou com o seu consentimento.

Como complemento, foi tipificada, no art. 185 do mesmo diploma legal, a conduta de fornecer componentes de produto patenteado, ou material ou equipamento para realizar processo patenteado, cuja aplicação final induza, necessariamente, à exploração do objeto da patente $^{165}$.

Os crimes contra os desenhos industriais estão previstos no artigo 187 e 188 da Lei $n^{0}$ 9.279/1996. A primeira conduta vedada é a fabricação, sem autorização do titular do registro do desenho industrial, de produto que incorpore o desenho industrial protegido ou que contenha imitação substancial que possa induzir terceiros a erro ou confusão ${ }^{166}$.

Também são apenadas as condutas secundárias de exportar, vender, expor ou oferecer à venda, ter em estoque ou receber para utilização com fins econômicos produto que incorpore o desenho industrial protegido ou que contenha imitação substancial que possa induzir terceiros a erro ou confusão, bem como importar produto da mesma natureza, para fins econômicos, sem que haja sido posto no mercado externo por seu titular ou por outrem com seu consentimento.

Os crimes contra as marcas estão previstos no artigo 189 e 190 da Lei $n^{\circ}$ 9.279/1996. Comete esse tipo de delito aquele que, sem a autorização do titular, reproduz, no todo ou em parte, marca registrada ou a imita de modo a confundir terceiros. Aquele

\footnotetext{
164 Comentando a legislação portuguesa, Alexandre Dias Pereira cria uma definição de atividades secundárias a qual podemos aproveitar para a legislação brasileira: "Prevê-se também a figura das infracções secundárias, na qual não há violação directa da propriedade mas antes aproveitamento derivado dessa violação.” (PEREIRA, Alexandre Dias, 2002, p. 24).

165 Cf. PIERANGELI, José Henrique. 2003. p. 201.

166 Cf. PIERANGELI, José Henrique. 2003. p. 208-214.
} 
que altera marca registrada de outrem já aplicada em produto colocado no mercado comete crime da mesma natureza.

Importação, exportação, venda, exposição para a venda, oferecimento, ocultação ou estocagem de produto com marca indevidamente reproduzida ou imitada de todo ou em parte, assim como produto embalado ou em recipiente ou vasilhame que contenha marca de terceiro são condutas consideradas secundárias à proteção das marcas, mas são igualmente vedadas, na forma do artigo 190 da Lei $n^{0} 9.279 / 1996^{167}$.

Os crimes cometidos por meio de marca, título de estabelecimento e sinal de propaganda estão previstos no artigo 191 da Lei $n^{0}$ 9.279/1996. Esse dispositivo veda a reprodução ou a imitação de armas, brasões ou distintivos oficiais nacionais, estrangeiros ou internacionais, no todo ou em parte, em marca, título de estabelecimento, nome comercial, insígnia ou sinal de propaganda, de modo a evitar a indução de terceiros a erro ou confusão.

São igualmente vedados o uso de tais reproduções para fins econômicos, a venda, a exposição ou o oferecimento à venda de produtos que contenham marca, título de estabelecimento, nome comercial, insígnia ou sinal de propaganda com a reprodução ou a imitação de armas, brasões ou distintivos oficiais nacionais, estrangeiros ou internacionais.

Os crimes contra indicações geográficas e demais indicações previstos nos artigos 192 a 194 da Lei $n^{0}$ 9.279/1996 se subdividem em três modalidades distintas, sendo a primeira a da prática de condutas de fabricar, importar, exportar, vender, expor ou oferecer à venda ou ter em estoque produtos que apresentem falsa indicação geográfica.

A segunda modalidade inclui: usar, em produto, recipiente, invólucro, cinta, rótulo, fatura, circular, cartaz ou em outro meio de divulgação ou propaganda, termos retificativos, para disfarçar a verdadeira procedência do produto.

A terceira modalidade veda o uso de marca, nome comercial, título de estabelecimento, insígnia, expressão ou sinal de propaganda ou qualquer outra forma de

${ }^{167}$ Cf. PIERANGELI, José Henrique. 2003. p. 225. 
indicação de procedência falsa do produto, além da venda ou da exposição à venda de produto com tais sinais.

Por fim, além dos tipos penais descritos, concorrência desleal específica, existe uma série de condutas típicas, concorrência desleal genérica, que têm por finalidade a proteção da concorrência, elemento essencial do mercado. Isto é, para o bom andamento das relações entre os agentes econômicos, são necessárias determinadas regras que, além de tutelar a propriedade industrial de terceiros, criem sanções para aqueles que se utilizam de métodos concorrenciais inidôneos na atividade comercial ou industrial.

A concorrência desleal distingue-se em especifica e genérica. Toma o nome de específica, quando se refere a certos atos, particularmente graves, que a lei considera crimes, subtraindo-os à teoria geral da concorrência desleal: são os fatos punidos pelas leis especiais sobre patentes de invenção, modelos de utilidade, desenhos e modelos industriais, nome comercial e marcas de fábrica e de comércio. Diz-se genérica, quando se trata de fatos não previstos nessas leis, caindo, assim, sob o domínio do direito comum. ${ }^{168}$

O traço comum dessas condutas, denominadas "concorrência desleal genérica", é punir a obtenção de vantagem decorrente de práticas desleais. Isto é, a existência de tais normas permite que o Estado proteja a propriedade industrial, bem como regule o exercício da atividade concorrencial quando esta for correlata à propriedade industrial.

Os crimes contra a propriedade industrial se dividem em seis partes e tutelam os seguintes objetos: patente de invenção; patente de modelo de utilidade; desenho industrial registrado; marca registrada; arma, brasão ou distintivo oficial nacional, estrangeiro ou internacional; marca; título de estabelecimento; nome comercial; insígnia ou sinal de propaganda; indicação geográfica e indicação de procedência; e lealdade concorrencial.

As condutas que violam essa proteção podem ser subdivididas em três grupos: 1) as consideradas principais quanto à violação dos direitos sobre a propriedade industrial, com sanções de detenção de três meses a um ano; 2) as consideradas secundárias quanto à violação dos direitos sobre a propriedade industrial, com sanções de detenção de um a três meses; 3) as condutas que, apesar de serem consideradas secundárias, são equiparadas às principais quanto à sanção em virtude do objeto tutelado.

168 CERQUEIRA, João da Gama. Tratado da propriedade industrial. Rio de Janeiro: Lumen Juris, $2010 \mathrm{c} . \mathrm{v}$. 2, tomo 2. p. 280. 
Por fim, cumpre ressaltar, para fins do presente trabalho, que os crimes contra a propriedade industrial são crimes de ação penal privada, exceto aqueles previstos no artigo 191 da Lei $n^{\circ} 9.279 / 1996^{169}$, na forma do disposto no artigo 199 do mesmo diploma legal.

\subsection{AUSÊNCIA DE ISONOMIA NA PROTEÇ̃̃o PENAL DA PROPRIEDADE IMATERIAL}

Como vimos, existe uma disparidade muito grande entre a proteção penal prevista para direitos de autor e direitos de autor de software e a proteção penal prevista para os direitos industriais. Tal desigualdade não pode ser justificada pela suposta diferença entre os titulares, uma vez que os direitos patrimoniais tanto de autor quanto de autor de software atualmente estão concentrados nas grandes empresas que detêm os mecanismos de reprodução e distribuição dos produtos.

De igual forma, essa disparidade não se justifica pelo escopo, uma vez que as modificações introduzidas ao sistema para combater a pirataria deveriam abranger os produtos industriais, os quais, por serem também objeto de contrafação por reprodução servil (pirataria), deveriam estar protegidos de forma isonômica no ordenamento jurídico brasileiro, com os mesmos mecanismos previstos para tal combate, tais como as medidas assecuratórias patrimoniais e as apreensões de todos os exemplares de cópias vis previstas no artigo 530-B do Código de Processo Penal.

A separação do objeto de proteção na esfera civil permite uma sistematização mais adequada na delimitação das regras de proteção de cada uma das espécies de propriedade imaterial. Contudo, abranger as normas penais em tal sistematização, com as posteriores mudanças trazidas pela Lei $\mathrm{n}^{0} 10.695 / 2003$, gerou uma distorção injustificada no sistema, impedindo ações efetivas de combate à pirataria de produtos.

169 “Art. 191. Reproduzir ou imitar, de modo que possa induzir em erro ou confusão, armas, brasões ou distintivos oficiais nacionais, estrangeiros ou internacionais, sem a necessária autorização, no todo ou em parte, em marca, título de estabelecimento, nome comercial, insígnia ou sinal de propaganda, ou usar essas reproduções ou imitações com fins econômicos. Pena - detenção, de 1 (um) a 3 (três) meses, ou multa. Parágrafo único. Incorre na mesma pena quem vende ou expõe ou oferece à venda produtos assinalados com essas marcas." 
Se o objeto da Lei $n^{0} 10.695 / 2003$ era criar mecanismos aptos ao combate eficiente da pirataria, poderia ter revogado todos os dispositivos penais existentes, sistematizando a matéria de forma isonômica no próprio Código Penal pela introdução do crime de pirataria, consistente na violação de direitos patrimoniais de autor/inventor pela vedação da reprodução servil, em mais de uma cópia, com fim de obter lucro.

Para solucionar o problema dos ambulantes ou camelôs, o tipo penal poderia dividir as atividades, agravando a pena daqueles que produzem, distribuem, introduzem no país, ocultam ou tem em depósito, com fins de comércio, ou vendem em grandes quantidades e suavizando a daqueles que expõem à venda ou vendem em pequenas quantidades, diferenciando os ambulantes das organizações criminosas que controlam a pirataria no Brasil.

Seria necessário também um tipo específico para coibir a pirataria realizada por meio da internet ou outras formas de compartilhamento de arquivos e conteúdo, com redação mais apurada ou mais atualizada que a verificada no parágrafo $3^{\circ}$ do novo texto do artigo 184 do Código Penal.

Estabelecidos os tipos penais relacionados ao combate à pirataria (de ação penal de iniciativa pública), outros tipos penais (de ação penal de iniciativa privada) deveriam contemplar as demais formas de contrafação, estabelecendo as hipóteses de violação por variantes de execução, equivalentes e aperfeiçoamento.

Em seguida, quatro tipos penais deveriam contemplar todas as hipóteses de concorrência desleal e de crimes contra as marcas, contra as indicações geográficas e de uso indevido de armas, brasões ou distintivos oficiais, estendendo de forma explícita a proteção para os direitos de autor e principalmente para os direitos de autor de software, uma vez que a indústria de software está sujeita às mesmas formas de concorrência desleal e violações de marcas que a indústria de produtos.

Por fim, ainda no campo penal, as modificações introduzidas pela Lei $\mathrm{n}^{\mathrm{o}}$ 10.695/2003 deveriam ter contemplado de forma expressa a proteção dos direitos morais de autor, assegurando o direito de reivindicar a autoria da obra ou ter seu nome, pseudônimo ou sinal convencional indicado ou anunciado como sendo o do autor; de 
conservar a obra inédita; de assegurar a integridade da obra, opondo-se a quaisquer modificações; de modificar a obra, antes ou depois de utilizada; de retirar de circulação a obra ou suspender qualquer forma de utilização já autorizada, quando a circulação ou a utilização implicarem afronta à sua reputação e à sua imagem.

Dessa forma, unificando o sistema de proteção penal, com os acréscimos mencionados, se resolveria o problema de falta de taxatividade e principalmente o de falta de isonomia na proteção penal da propriedade imaterial, permitindo, assim, que as medidas introduzidas pela Lei $\mathrm{n}^{\mathrm{o}} 10.695 / 2003$ atingissem também a pirataria de produtos industriais.

Para o processo penal, entretanto, a reforma trouxe uma mudança significativa, diferenciando o procedimento dos crimes de ação penal de iniciativa pública dos crimes de ação penal de iniciativa privada, principalmente ao criar uma modalidade de busca e apreensão que não existia no sistema processual penal brasileiro.

No procedimento dos crimes de ação penal de iniciativa privada, não houve mudança substancial, mantendo-se como condição de procedibilidade, para os crimes que deixam vestígios, a promoção de medida cautelar de produção antecipada de provas, precedida de uma medida de busca e apreensão obrigatória. Por meio dessa medida de busca e de apreensão, o titular da propriedade imaterial deve requerer a apreensão de exemplares do objeto que viola tais direitos, para a realização de exame pericial apto a comprovar a materialidade do delito.

O procedimento dos crimes de ação penal de iniciativa pública, entretanto, foi completamente modificado, mantendo-se, por um lado, a produção antecipada de provas pela realização de exame pericial, como condição de procedibilidade para os crimes que deixam vestígios; por outro, foi criada uma nova modalidade de medida de busca e apreensão, que deixou de ser um instrumento a serviço do processo e passou a ter natureza satisfativa, pela apreensão $a b$ initio de todos os objetos incriminados ${ }^{170}$.

170 “Art. 3o O Capítulo IV do Título II do Livro II do Decreto-Lei no 3.689, de 3 de outubro de 1941, passa a vigorar acrescido dos seguintes arts. 530-A, 530-B, 530-C, 530-D, 530-E, 530-F, 530-G, 530-H e 530-I: [...] Art. 530-B. Nos casos das infrações previstas nos $\S \S 1$ o, 20 e 3o do art. 184 do Código Penal, a autoridade policial procederá à apreensão dos bens ilicitamente produzidos ou reproduzidos, em sua 
Como veremos, essa nova medida de busca e apreensão, criada com o escopo de permitir a apreensão, no início do procedimento, de todos os objetos contrafeitos, vai na contramão de toda a regulamentação histórica das medidas de busca e apreensão, sempre previstas como forma de controlar a atividade dos agentes do Estado e os excessos cometidos desde os tempos do Brasil colônia.

Além disso, a nova medida de busca e apreensão deve ser examinada à luz do texto constitucional de 1988, em especial sob a ótica do princípio da presunção de inocência, visto que pelo referido princípio são vedadas todas e quaisquer formas de antecipação dos efeitos penais da sentença condenatória e, por esse motivo, são vedadas todas as medidas satisfativas ou que importem, de alguma forma, na antecipação do juízo de autoria e culpabilidade.

Por esse motivo, passaremos agora para uma breve análise da regulamentação das medidas de busca e de apreensão na legislação brasileira, bem como dos limites constitucionais e das perspectivas de futuro, passando por um breve estudo de direito comparado, para, em seguida, diferenciar o instituto da busca do instituto da apreensão, analisando a aplicabilidade destes no procedimento comum e em ambos os procedimentos dos crimes contra a propriedade imaterial.

totalidade, juntamente com os equipamentos, suportes e materiais que possibilitaram a sua existência, desde que estes se destinem precipuamente à prática do ilícito." (Grifo nosso). 


\section{CAPÍTULO III - DA BUSCA E DA APREENSÃO}

\subsection{A BUSCA E A APREENSÃo NA LEGISLAÇ̃̃o BRASILEIRA}

No Brasil, o primeiro diploma legal que disciplinou a busca e a apreensão foi a Lei de 14 de outubro de $1822^{171}$, que, incorporada à legislação pátria, estabelecia regras para a entrada em casa alheia. Aquela norma proibia a entrada à noite; tornava indispensáveis a assistência de escrivão, a presença de testemunhas e a ordem escrita do juiz; limitava a entrada a algumas hipóteses (prisão de criminosos, busca e apreensão de contrabando e de coisas furtadas e verificação da polícia); autorizava a penhora; permitia a entrada sem as formalidades em casos de flagrante delito; impunha respeito ao morador; previa a punição do executor por transgressões à lei ${ }^{172}$.

Entretanto, pela falta de respeito às regras estabelecidas e pelas arbitrariedades que eram cometidas pelas autoridades locais, em 15 de julho de 1823, o imperador Dom Pedro I, em proclamação, estabeleceu a inviolabilidade dos direitos à segurança individual e à propriedade e a imunidade da casa do cidadão ${ }^{173}$.

Em 1832 foi promulgado o Código de Processo Criminal do Império ${ }^{174}$, que sistematizou pela primeira vez as medidas de busca e apreensão. Entretanto,

171 BRASIL. Lei de 14 de outubro de 1822. Combina o respeito devido á casa do Cidadão com a administração da Justiça. Disponível em: <http://www2.camara.leg.br/legin/fed/lei_sn/anterioresa1824/ lei-38920-14-outubro-1822-568217-publicacaooriginal-91612-pl.html>. Acesso em: 29 jun. 2012.

172 MENDES JR., João de Almeida. O processo criminal brasileiro. Rio de Janeiro: Typografia Batista de Souza, 1920. v. 2. p. 46-48.

173 “Ainda que por ora não tenhamos uma Constituição, pela qual nos governemos; comtudo temos aquellas bases estabelecidas pela razão, as quaes devem ser inviolaveis: são ella; - os sagrados direitos da segurança individual, e de propriedade, e da immunidade da casa do cidadão. - Si até aqui ellas têm sido atacadas, e violadas, é porque vosso Imperador não tinha sabido, que se praticavam semelhantes despotismos, e arbitrariedades, improprias de todos os tempos, e contrarias ao systema, que abraçamos. Ficai certos que ellas serão de hoje em diante mantidas religiosamente - vos vivireis felizes, seguro no seio de vossas familias, nos braços de vossas ternas esposas, e rodeados de vossos caros fillhos. Embora incautos queiram denegrir a minha constitucionalidade, ella sempre apparecerá, triumphante, qual sol dissipando o mais espesso nevoeiro. Contai commigo assim como eu conto comvosco, o vereis - a democracia, e o despotismo agrilhoados por uma justa liberdade." MENDES JR., João de Almeida, 1920, p. 49. Texto na íntegra em: BRASIL. Proclamação - de 15 de julho de 1823. Detesta o despotismo e assegura os sagrados direitos dos cidadãos. Disponível em: <http://www6.senado.gov.br/legislacao/ ListaTextoIntegral.action?id=70281>. Acesso em: 1 jan. 2013.

${ }^{174}$ BRASIL. Lei de 29 de novembro de 1832. Promulga o Codigo do Processo Criminal de primeira instancia com disposição provisoria ácerca da administração da Justiça Civil. Disponível em: <http://www.planalto.gov.br/ccivil_03/Leis/LIM/LIM-29-11-1832.htm>. Acesso em: 29 jun. 2012. 
[...] o instituto da apreensão, no Código de Processo Criminal do Império, não se disciplinou em apartado e se viu inserido como objetivo da busca. Estatuiu o Código que o mandado de busca se concedia para apreender coisas furtadas, ou tomadas pela força, ou com falsos pretextos, ou achadas; instrumentos de falsificação, moeda falsa ou outros objetos falsificados e armas e munições, preparadas para insurreição, ou motim e para quaisquer outros crimes $\left(\S \S 1^{\circ}, 3^{\circ} \mathrm{e}\right.$ $4^{\circ}$ do art. 189). ${ }^{175}$

Aqui podemos estabelecer o primeiro marco conceitual, no qual a apreensão é tida como objetivo da busca e, por tal motivo, não seria um instituto processual autônomo merecedor de disciplina própria.

A mesma sistemática foi adotada nas legislações estaduais, quando da vigência da Constituição Brasileira de $1891^{176}$, que em seu artigo $34, \S 23^{\circ}$, retirou do Congresso Nacional a competência para legislar em matéria processual, exceto a de âmbito da Justiça Federal, delegando, por consequência, tal competência aos Estados.

A alteração na regra de competência legislativa em matéria processual penal desencadeou a elaboração de códigos de processo penal estaduais, que trataram as buscas como indissociáveis das apreensões, como foi o caso do Rio Grande do Sul, em 1898 (art. 144), Amazonas, em 1917 (art. 71), Sergipe (art. 58) e Rio Grande do Norte, em 1918 (art. 214), Alagoas, em 1919 (art. 76), Paraná, em 1920 (art. 307), Distrito Federal, em 1924 (art. 171), Maranhão, em 1926 (art. 40), e Minas Gerais, em 1930 (art. 176) ${ }^{177}$.

Com a promulgação da Constituição da República dos Estados Unidos do Brasil de $1934^{178}$, a matéria processual voltou a ser de competência exclusiva da União, sendo elaborado o denominado "Projeto Vicente Ráo" ${ }^{179}$, que sequer chegou a ser votado e que também tratava as apreensões em conjunto com as buscas no título IX, "Das provas".

175 PITOMBO, Cleunice A. Valentim Bastos. Da busca e da apreensão no processo penal. 2. ed. rev., atual. e amp. São Paulo: Revista dos Tribunais, 2005. (Coleção estudos de processo penal Joaquim Canuto Mendes de Almeida, v. 2). p. 32.

176 BRASIL. Constituição da República dos Estados Unidos do Brazil de 1891. Disponível em: $<$ http://www.planalto.gov.br/ccivil_03/constituicao/constituiçao91.htm>. Acesso em: 15 jul. 2012.

177 Cf. PITOMBO, Cleunice A. Valentim Bastos, 2005, p. 37-42. ESPINOLA FILHO, Eduardo. Código de processo penal brasileiro anotado. 3. ed. Rio de Janeiro: Livraria Freitas Bastos, 1942. v. 3. p. 165-166.

178 BRASIL. Constituição da República dos Estados Unidos do Brasil de 1934. Disponível em: $<$ http://www.planalto.gov.br/ccivil_03/constituicao/constituiçao34.htm>. Acesso em: 15 jul. 2012.

179 "O projeto foi elaborado por Bento de Faria, Plinio Casado e Gama Cerqueira, sob a presidência do Ministro da Justiça, na época, Vicente Ráo." (PITOMBO, Sérgio Marques de Moraes. Do sequestro no processo penal brasileiro. São Paulo: José Bushatsky, 1973, p. 103). 
Após o golpe de Estado de 1937, foi formada nova comissão ${ }^{180}$, que elaborou novo projeto de Código de Processo Penal, promulgado em 3 de outubro de 1941 pelo DecretoLei $n^{\mathrm{o}} 3.689 / 41^{181}$, que entrou em vigor, junto com o Código Penal, em $1^{\mathrm{o}}$ de janeiro de 1942 e está vigente até hoje.

Seguindo a mesma técnica legislativa dos diplomas anteriores, o Código de Processo Penal vigente também disciplinou a apreensão como objetivo da busca e por tal motivo não se deu a ela tratamento distinto, como se os institutos fossem indissociáveis um do outro.

\subsection{LIMITES CONSTITUCIONAIS DA BUSCA E DA APREENSÃO}

"Todas as Constituições Brasileiras, sempre, preocuparam-se em proteger a casa do indivíduo, contra ingerências arbitrárias, independentemente da forma de governo ou do regime político vigente à época de sua elaboração e promulgação."182

Desde a primeira constituição brasileira, a Constituição Política do Império do Brazil de $1824^{183}$, já existia a previsão de que a casa do cidadão é asilo inviolável. Naquele texto, além da inviolabilidade do domicílio, foi estabelecido que só poderia haver entrada, à noite, com o consentimento do indivíduo ou em casos de incêndio ou inundações e, de dia, nos casos e na forma prescrita pela lei.

A Constituição republicana de 1891 utilizou a mesma fórmula para declarar que a casa é o asilo inviolável do indivíduo e que nela ninguém poderá penetrar nem de noite, senão para acudir vítimas de crimes ou desastres, nem de dia, senão nos casos e na forma prescrita pela lei. Observamos aqui que pela primeira vez se fez inserir a hipótese de entrada durante a noite para acudir vítimas de crimes.

180 "No Projeto do Código de Processo Penal em vigor, trabalharam, Narcélio de Queiroz, Nelson Hungria, Vieira Braga, Candido Mendes, Florêncio de Abreu e Roberto Lira." (PITOMBO, Sérgio Marques de Moraes. 1973, p. 105).

181 BRASIL. Decreto-Lei $n^{o}$ 3.689, de 3 de outubro de 1941. Código de Processo Penal. Disponível em: $<$ https://www.planalto.gov.br/ccivil_03/decreto-lei/Del3689.htm>. Acesso em: 15 jul. 2012.

182 PITOMBO, Cleunice A. Valentim Bastos, 2005, p. 53.

183 BRASIL. Constituição da Política do Império do Brazil de 1824. Disponível em: <http://www.planalto.gov.br/ccivil_03/constituicao/constituiçao24.htm>. Acesso em: 15 jul. 2012. 
A Constituição republicana de 1934 reproduziu de forma idêntica a ideia de proteção ${ }^{184}$, que foi modificada logo em seguida pela Constituição dos Estados Unidos do Brasil de $1937^{185}$, decretada no período ditatorial, substituindo a proteção existente pela simples previsão de que eram invioláveis o domicílio e as correspondências, salvo nas exceções previstas em lei.

A Constituição dos Estados Unidos do Brasil de $1946^{186}$ e a Constituição da República Federativa do Brasil de $1967^{187}$ resgataram a técnica legislativa da Constituição de 1934, prevendo a garantia de forma mais abrangente, sendo que a primeira permitia a entrada à noite para acudir vítimas de crime, enquanto a segunda estabeleceu a exceção para casos de crimes, abrangendo também as hipóteses de prisão, sem limitar de forma explicita que a exceção permitia apenas os casos de prisão em flagrante delito.

Por fim, a Constituição da República Federativa do Brasil de $1988^{188}$ ampliou a proteção, estabelecendo que a casa é asilo inviolável, cuja entrada só poderá ocorrer com consentimento do morador, ou em casos de flagrante delito ou desastre, ou para a prestação de socorro, ou, durante o dia, por determinação judicial.

Cumpre observar que em todas as constituições vigentes no país, a limitação mais importante à busca e à apreensão sempre foi a proteção da casa, que, pela garantia constitucional repetida em todos os textos das constituições, exceto no da Constituição de 1934, é asilo inviolável do indivíduo, local onde ele pode manifestar e desenvolver o seu direito à intimidade e à vida privada.

As buscas, portanto, devem respeitar, primeiro, os limites da inviolabilidade da casa do indivíduo, insculpidos no inciso XI do artigo $5^{\circ}$ da Constituição Federal.

\footnotetext{
184 “Art. 113 - [...] 16) A casa é o asilo inviolável do indivíduo. Nela ninguém poderá penetrar, de noite, sem consentimento do morador, senão para acudir a vítimas de crimes ou desastres, nem de dia, senão nos casos e pela forma prescritos na lei."

185 BRASIL. Constituição da República dos Estados Unidos do Brasil de 1937. Disponível em: $<$ http://www.planalto.gov.br/ccivil_03/constituicao/constituiçao37.htm>. Acesso em: 15 jul. 2012.

186 BRASIL. Constituição da República dos Estados Unidos do Brasil de 1946. Disponível em: $<$ http://www.planalto.gov.br/ccivil_03/constituicao/constituiçao46.htm>. Acesso em: 15 jul. 2012.

187 BRASIL. Constituição da República Federativa do Brasil de 1967. Disponível em: <http://www.planalto.gov.br/ccivil_03/constituicao/constituiçao67.htm>. Acesso em: 15 jul. 2012.

188 BRASIL. Constituição da República Federativa do Brasil de 1988. Disponível em: $<$ http://www.planalto.gov.br/ccivil_03/constituicao/constituicao.htm>. Acesso em: 15 jul. 2012.
} 
Garantia antiga e sempre repetida nos textos constitucionais é a da inviolabilidade do domicílio (art. $5^{\circ}, \mathrm{XI}$ ), pois é este o sagrado refúgio da pessoa, onde ela deve poder, no convívio de seus familiares, ou em total isolamento, exprimir a sua individualidade com inteiro resguardo de sua intimidade ou de sua vida privada. Não se cuida de garantia absoluta, podendo o domicílio ser violado quando há suspeita razoável de que nele esteja sendo cometida infração penal e, por isso, a Constituição admite a violação "em caso de flagrante delito". Também é cabível o ingresso sem o consentimento do morador quando o juiz o autorize, mas, nesta hipótese, apenas durante o dia. Fora dessas hipóteses, qualquer prova obtida com violação do domicílio, é ilícita. ${ }^{189}$

O conteúdo constitucional da inviolabilidade da casa, entretanto, não se restringe à definição fornecida pelo direito penal, prevista no parágrafo $4^{\circ}$ do artigo 150 , do Código Penal $^{190}$, que conceitua casa como qualquer compartimento habitado, aposento ocupado de habitação coletiva ou compartimento não aberto ao público onde alguém exerce profissão ou atividade.

\section{Segundo a Professora Cleunice Bastos Pitombo, a}

[...] expressão "casa" deve abranger: (a) a habitação definitiva, ou morada transitória; (b) casa própria, alugada, ou cedida; (c) dependências da casa, sendo cercadas, gradeadas, ou muradas; (d) qualquer compartimento habitado; (e) aposento ocupado de habitação coletiva, em pensões, hotéis e em casas de pousada; (f) estabelecimentos comerciais e industriais, fechados ao público; (g) local onde se exerce atividade profissional, não aberto ao público; (h) barco, trailer, cabine de trem ou navio e barraca de acampamento; (i) áreas comuns de condomínio, vertical ou horizontal. ${ }^{191}$

Dentro dessa visão mais ampla, o que se busca de forma mediata é o respeito à intimidade e à vida privada do indivíduo. Sendo assim, as buscas domiciliares devem respeitar, em segundo lugar, a vida privada e a intimidade do indivíduo, cuja proteção está prevista de forma expressa no inciso $\mathrm{X}$ do artigo $5^{\circ}$ da Constituição Federal ${ }^{192}$.

Por outro lado, devemos destacar que, pelo objeto de proteção das normas previstas nos incisos X e XI do artigo $5^{\circ}$ da Constituição Federal, a norma que prevê a inviolabilidade da intimidade e da vida privada é formada por princípios, enquanto a

189 FERNANDES, Antonio Scarance. Processo penal constitucional. 6. ed. São Paulo: Revista dos Tribunais, 2010. p. 103.

190 “\$ $4^{\circ}$ - A expressão 'casa' compreende: I - qualquer compartimento habitado; II - aposento ocupado de habitação coletiva; III - compartimento não aberto ao público, onde alguém exerce profissão ou atividade.".

191 PITOMBO, Cleunice A. Valentim Bastos, 2005, p. 72.

192 “A atual Constituição da República inovou, ao proteger a intimidade e a vida privada (art. $5^{\circ}$, inc. X). A abrangência da norma acha-se em fase de elaboração doutrinária." (PITOMBO, Cleunice A. Valentim Bastos, 2005, p. 72). 
norma que prevê a inviolabilidade da casa do indivíduo é uma regra, motivo pelo qual teremos consequentemente abrangência e aplicação distintas.

Os princípios, na distinção proposta por Robert Alexy, são normas jurídicas que determinam que algo seja realizado, dentro das possibilidades existentes, na maior medida possível, enquanto as regras devem ser sempre cumpridas. Logo, os princípios são mandamentos de otimização, que pode ser cumpridos em diferentes graus, enquanto as regras são ou não são cumpridas ${ }^{193}$.

A diferença, portanto, não está na estrutura da norma, e sim no conteúdo. "Tanto las reglas como los principios son normas porque ambos dicen lo que debe ser. Ambos pueden ser formulados con la ayuda de las expresiones deónticas básicas de mandato, la permisión y la prohibición.",194

Evidente que essa escolha não decorre da estrutura da norma, e sim do objeto de proteção $^{195}$, visto que a inviolabilidade da casa pode ser uma norma absoluta, com as exceções previstas no próprio texto constitucional ou nas normas infraconstitucionais, enquanto a intimidade e a vida privada não podem ser absolutas porque o próprio processo, em especial o processo penal, como instrumento de descoberta de fatos passados, que necessariamente levará a uma intromissão na vida privada do indivíduo.

193 ALEXY, Robert. Teoría de los derechos fundamentales. Madrid: Centro de Estúdios Políticos y Constitucionales, 1997. p. 86-87.

194 ALEXY, Robert, 1997, p. 83.

195 J. J. Gomes Canotilho sistematizou todos os critérios de distinção entre regras e princípios da seguinte forma: "a) pelo grau de abstração, quando os princípios têm grau de abstração mais elevado e as regras, mais reduzido; b) pelo grau de determinabilidade no caso concreto, pois os princípios carecem de mediação concretizadora e as regras são suscetíveis de aplicação imediata; c) pelo caráter de fundamentalidade no sistema das fontes de direito, em que os princípios se diferenciam das regras por terem papel no ordenamento jurídico, devido à sua posição hierárquica no sistema das fontes ou à sua importância estruturante no ordenamento jurídico; d) pela "proximidade" da ideia de direito, uma vez que os princípios são standards juridicamente vinculantes, radicados nas exigências de justiça ou na ideia de direito, e as regras podem ter um conteúdo meramente funcional; e) pela natureza normogenética, já que os princípios são fundamentos de regras ou constituem a ratio de regras jurídicas, exercendo, assim, uma função normogenética fundamentante. Mais importante do que a sistematização dos critérios de diferenciação de regras e princípios feita por Canotilho é a diferenciação qualitativa. Distinguem-se as normas jurídicas que são regras daquelas que são princípios, por serem as primeiras formadas por uma estrutura lógico-deôntica, em que há descrição de uma hipótese fática e previsão de uma consequência jurídica, e serem as segundas os chamados "mandados de otimização", por prescreverem valores que devem ser levados em conta na análise dos casos concretos e na interpretação de todo o ordenamento jurídico." (IOKOI, Pedro Ivo Gricoli. Prisão preventiva e princípio da proporcionalidade. São Paulo: Dissertação de Mestrado, Faculdade de Direito, Universidade de São Paulo, 2005, p. 16-17). 
Ademais, como bem explanou a professora Ada Pellegrini Grinover, no processo penal o direito à intimidade não é um direito absoluto.

A problemática da intimidade integra o pano de fundo do processo penal, na medida em que o Estado, na persecução dos fins punitivos, exerce uma atividade investigatória que leva quase necessariamente a uma intromissão, na esfera privada do indivíduo. E se, de um lado, o direito à intimidade é parte integrante dos direitos à personalidade, envolvendo a liberdade do homem, é igualmente certo que todas as liberdades têm feitio e finalidade éticos, não podendo ser utilizados para proteger abusos e acobertar violações. ${ }^{196}$

Assim, a proteção à intimidade e à vida privada são princípios que devem ser observados da forma mais abrangente possível.

Isso importa dizer que é natural que, para a execução dos mandados de busca e apreensão, se interfira na vida privada e na intimidade dos indivíduos que sofrem a devassa. Contudo, devem ser observados os escopos previstos no mandado de busca, restringindo o varejamento aos objetos relacionados ao crime investigado e deixando incólumes os objetos que não estão relacionados com a infração penal.

Entretanto, hoje, as novas tecnologias cibernéticas permitem a execução de medidas de busca sem a entrada física na casa do investigado, realizadas por meio da rede mundial de computadores, a qual permite devassar os microcomputadores do investigado sem o seu conhecimento ou o seu consentimento, bem como os arquivos deixados em sistemas de cloud computing ${ }^{197}$ em servidores localizados em diversos países.

196 GRINOVER, Ada Pellegrini. Novas tendências do direito processual. São Paulo: Forense Universitária, 1990. p. 60.

197 “O conceito de computação em nuvem (em inglês, cloud computing) refere-se à utilização da memória e das capacidades de armazenamento e cálculo de computadores e servidores compartilhados e interligados por meio da Internet, seguindo o princípio da computação em grade. O armazenamento de dados é feito em serviços que poderão ser acessados de qualquer lugar do mundo, a qualquer hora, não havendo necessidade de instalação de programas x ou de armazenar dados. O acesso a programas, serviços e arquivos é remoto, através da Internet - daí a alusão à nuvem." (COMPUTAÇÃO em nuvem. In: WIKIPÉDIA. Disponível em: <http://pt.wikipedia.org/wiki/Computação_em_nuvem>. Acesso em: 12 dez. 2012.) 


\subsection{AS BUSCAS E AS APREENSÕES DIGITAIS}

Como vimos, a regulamentação da busca e da apreensão se desenvolveu com base na noção de que a casa do indivíduo é o local no qual ele exerce o seu direito à intimidade e à vida privada, motivo pelo qual sempre foi objeto de proteção das legislações pátrias, pela regra da inviolabilidade.

A proteção da casa era a forma mais adequada de resguardar um espaço no qual o legítimo possuidor é quem determina quem pode entrar, quando pode entrar, quando deve sair, as regras de conduta mínimas exigidas dentro daquele local, a disposição dos bens e dos móveis, a separação dos ambientes, etc.

Enfim, a proteção da casa permitia o livre desenvolvimento da intimidade e da vida privada, garantindo ao sujeito desses direitos a proteção das atividades ali exercidas e das coisas guardadas naquele local. Entretanto, hoje, com o desenvolvimento de novas tecnologias, a invasão da casa não se limita à entrada pelas portas ou pelas janelas; é possível entrar e bisbilhotar por meio da rede mundial de computadores, é possível acessar e devassar fotos, documentos, vídeos, extratos bancários e correspondências sem sequer se aproximar da casa do investigado.

Uma infinidade de condutas que violam a intimidade e a vida privada hoje são possíveis pela presença e pelo uso massificado de dispositivos eletrônicos conectados com a internet, permitindo inclusive o uso anômalo de tais dispositivos com o objetivo de monitorar e escutar clandestinamente as conversas privadas dos usuários.

Por esse motivo podemos afirmar que estamos entrando em um segundo marco conceitual, no qual a proteção da intimidade e da vida privada por meio da regra da inviolabilidade da casa do indivíduo não é eficaz para proteger o indivíduo das intromissões realizadas por meio de dispositivos eletrônicos conectados com a rede mundial de computadores. 
Se a proteção anterior permitia que o indivíduo se utilizasse de força física para repelir as invasões de sua casa, além do uso de ofendículos ${ }^{198}$ para proteger a casa em sua ausência ou durante o período noturno, agora não existem mecanismos aptos a coibir a invasão físicamente, de modo a devolver ao agressor uma repulsa proporcionalmente equivalente.

Muito pelo contrário, as invasões dos dispositivos eletrônicos só podem ser combatidas com programas de computador popularmente conhecidos como antivírus e firewall $^{199}$. Tais programas têm como escopo detectar e impedir a entrada de programas maliciosos que destroem o sistema operacional dos dispositivos ou que permitem violar a privacidade e obter ilicitamente dados bancários, de cartões de crédito, ou mesmo de perfil — seja de navegação na rede, seja de consumo — dos usuários.

A popularização dos microcomputadores também trouxe reflexos para as medidas de busca e apreensão, pois, além de varejar e apreender os objetos tradicionalmente conhecidos, se passou a apreender dispositivos eletrônicos ${ }^{200}$, com o argumento de que tais dispositivos poderiam estar relacionados com a infração penal e, portanto, estariam abrangidos nas hipóteses previstas no Código de Processo Penal.

Após a apreensão, os dispositivos eram submetidos a exames periciais, que tinham como principal objetivo romper as senhas de usuários e os programas de criptografia, a fim de alcançar e devassar os arquivos digitais ali armazenados, ainda sob o pretexto de que tais arquivos poderiam ter relação com a prática criminosa.

198 "Em torno do requisito da atualidade (ou iminência) da agressão, trava-se controvérsia a propósito do uso de aparelhos ocultamente predispostos para a defesa da propriedade (offendiculla ou offensacula, dos práticos; Schuntzvorrichtunge ou Abwehrungmassregeln, dos autores alemães). Em tal caso a defesa é preparada de antemão, isto é, quando o perigo é ainda futuro; mas o funcionamento do offendiculum é necessàriamente subordinado à efetividade da agressão. [...] Ora, o direito de propriedade (como qualquer direito por mais relevante) não tem como corolário o direito, mas a simples faculdade de lesar outrem para sua defesa. Como já foi dito acima, não há direito sem o correlativo de um dever, e seria absurdo falar-se em dever de se deixar lesar. O que ocorre na espécie é, sem dúvida alguma, legítima defesa." (HUNGRIA, Nelson. Comentários ao código penal. 4. ed. Rio de Janeiro: Forense, 1958. v. 1. tomo 2. p. 293-294).

199 Os programas de computador conhecidos como firewall e antivírus movimentam cifras milionárias na indústria de software, que produz atualizações diárias, permitindo a venda dos programas com licenças anuais, que garantem a arrecadação permanente de novas licenças para o mesmo programa.

200 "Ocorre que, em tempo presente, é cada vez mais rotineiro presenciar operações policiais em que dezenas de computadores são apreendidos apenas com o escopo de serem capturados os dados armazenados em seus discos rígidos" (SOUZA, Diego Fajardo Maranha Leão de. Busca e apreensão digital: prova penal atípica. Boletim IBCCrim, São Paulo, n. 181, v. 15, p.14-15, 2007, p. 14). 
Iniciou-se então uma discussão sobre o conteúdo e a abrangência do inciso XII do artigo $5^{\circ}$ da Constituição Federal. O referido dispositivo constitucional determina que

[...] é inviolável o sigilo da correspondência e das comunicações telegráficas, de dados e das comunicações telefônicas, salvo, no último caso, por ordem judicial, nas hipóteses e na forma que a lei estabelecer para fins de investigação criminal ou instrução processual penal.

Pela interpretação gramatical da norma constitucional, é vedada a violação do sigilo da correspondência, das comunicações telegráficas e de dados, permitindo-se apenas a violação de sigilo das comunicações telefônicas, por ordem judicial, para fins de investigação criminal ou instrução processual penal.

Entretanto, como bem ensinou a professora Ada Pellegrini Grinover, as liberdades públicas só podem ser asseguradas e exercidas de forma ética, não podendo servir para fins antiéticos $^{201}$, motivo pelo qual "[...] a garantia constitucional do sigilo da correspondência e das comunicações telegráficas e telefônicas não pode ser entendida em sentido absoluto, diante da própria evolução do conceito de liberdades públicas."202.

\begin{abstract}
A matéria foi objeto de acurada análise por Ada Pellegrini Grinover, em sua obra Liberdades Públicas - As interceptações telefônicas, destacando ela a necessidade de estabelecer limites legais à inviolabilidade do sigilo das comunicações tendo em vista o interesse público, como acontece com outros princípios constitucionais, além de enfatizar a absoluta inadmissibilidade processual da prova ilícita obtida com infração das normas constitucionais. Por isso ofereceu, com apoio de outros processualistas, sugestões à Constituinte no sentido de incluir menção expressa no texto da Lei Magna, o que afinal ocorreu, dispondo o seu art. $5^{\circ}$, XII ser inviolável o sigilo da correspondência e das comunicações telegráficas, de dados e das comunicações telefônicas, "salvo, no último caso, por ordem judicial, nas hipóteses e na forma que a lei estabelecer para fins de investigação criminal ou instrução processual penal". ${ }^{203}$
\end{abstract}

O mesmo raciocínio deve ser estendido para o sigilo de dados, visto que hoje o conceito de dados é diverso daquele previsto pela norma constitucional, que estabelecia a inviolabilidade de informações pessoais confidenciais armazenadas nos arquivos públicos e privados de bancos, serviços de proteção de crédito e na Secretaria da Receita Federal ${ }^{204}$.

201 “À inviolabilidade da correspondência e das comunicações telegráficas e telefônicas devem ser fixados limites para não dificultar a proteção dos outros direitos; limites esses a serem bem fixados, sob pena de destruição da garantia constitucional da liberdade e do sigilo da correspondência e das comunicações." (ARAUJO, José Laércio. Intimidade, vida privada e direito penal. São Paulo: Habeas, 2000. p. 91).

202 GRINOVER, Ada Pellegrini, 1990, p. 306.

203 FERREIRA, Ivette Senise. A intimidade e o direito penal. Revista Brasileira de Ciências Criminais, São Paulo, v. 5, p. 96-106, 1994. p. 102.

${ }^{204}$ Cf. FERREIRA, Ivette Senise, 1994, p. 102. 
Hoje, as comunicações telefônicas e as correspondências podem ser realizadas por meio de trocas de arquivos na internet ${ }^{205}$, bem como qualquer informação escrita, sonora ou visual é passível de conversão e armazenamento em dados de computador. Dessa forma, uma vez que o objeto é diverso daquele previsto na norma constitucional, não se pode utilizar a inviolabilidade dos dados prevista na norma constitucional como forma de proteção ao exercício antiético e ilícito dessa liberdade pública.

Com base nesse raciocínio, é lícito entender que os dados de computador são passíveis de apreensão, por ordem judicial, para fins de investigação criminal ou para a instrução de processo penal.

Entretanto, hoje, com os novos mecanismos de armazenamento de dados em "nuvens" 206 - que permitem que os arquivos não sejam mais guardados nos dispositivos dos usuários, mas passem a ser armazenados em servidores virtuais, cuja localização física não importa —, bem como com a popularização da rede mundial de computadores, que permite a remessa constante de dados para fora dos dispositivos dos usuários, a busca física dos dispositivos eletrônicos não atinge mais os fins almejados ${ }^{207}$.

A primeira norma exclusivamente destinada ao tratamento penal de atos praticados por meio da internet é extremamente recente, desencadeada por um episódio isolado ocorrido com uma atriz famosa, de uma grande emissora de televisão, que teve um dispositivo eletrônico devassado e as fotografias intimas ali armazenadas ilicitamente divulgadas na rede mundial de computadores.

O projeto de lei, de autoria do deputado Paulo Teixeira, foi sancionado pela presidente Dilma Rousseff após aprovação na Câmara dos Deputados e no Senado Federal, com as modificações introduzidas pela Comissão de Ciência e Tecnologia do Senado. O

\footnotetext{
205 As correspondências eletrônicas realizadas por e-mail e as conversas telefônicas realizadas via sistema voice over internet protocol (VOIP) são tão populares quanto os sistemas tradicionais de correspondência e telefonia.

206 Nesse sentido: SOUZA, Diego Fajardo Maranha Leão de, 2007, p. 15.

207 Além do armazenamento em nuvens, outro problema que se enfrenta é o decorrente da popularização dos dispositivos de armazenamento denominados "pen-drives", que tornaram obsoletos os disquetes, os CDs e os DVDs, seja pela capacidade de armazenamento muito superior, seja pelo tamanho reduzido (pouco mais de três centímetros), que permite que em um único dispositivo se armazene uma infinidade de arquivos.
} 
projeto original previa a introdução de alguns dispositivos no Código Penal, com o escopo de criminalizar não só a invasão de dispositivos eletrônicos, como também as fraudes bancárias praticadas por meio da rede mundial de computadores, as quais, segundo a Febraban, causam prejuízos anuais bilionários às instituições financeiras brasileiras ${ }^{208}$.

Entretanto, a Lei $n^{0} 12.737 / 2012^{209}$, publicada no Diário Oficial da União em 3 de dezembro de 2012, criminalizou apenas as invasões de dispositivos informáticos mediante violação de dispositivo de segurança e a produção, a difusão e a distribuição de programas de computador destinados à invasão ilícita de dispositivos informáticos.

Cumpre aqui destacar duas críticas ao texto aprovado que podem ser transpostas ao objeto de estudo do presente trabalho. Primeiro, o texto de lei identificou o objeto de proteção como dispositivo informático, restringindo a proteção, enquanto poderia ter utilizado a definição "dispositivo eletrônico", uma vez que, hoje, já existem inúmeros eletrodomésticos que se conectam com a rede mundial de computadores, tais como televisores, videogames, celulares, tablets, geladeiras, etc.

Segundo, no texto a proteção está condicionada ao preenchimento de um dos elementos do tipo penal, "mediante violação indevida de mecanismo de segurança", que restringe a proteção penal apenas aos atos praticados com violação de tais mecanismos. Não nos parece isonômico restringir a proteção apenas aos dispositivos que possuem senhas ou outros mecanismos de segurança, uma vez que a invasão de dispositivos com "portas abertas ou fechadas" deveria ser igualmente protegida.

Seria mais harmônico com o nosso sistema penal se esse elemento do tipo penal fosse utilizado como circunstância qualificadora do crime, ou causa de aumento de pena,

208 “As perdas com fraudes bancárias realizadas por meio eletrônico somaram R \$ 685 milhões no primeiro semestre de 2011, o que representa um aumento de 36\% em relação ao mesmo período do ano passado, que foi de R\$ 504 milhões. Os dados são da Federação Brasileira dos Bancos - FEBRABAN. Para Wilson Gutierrez, diretor Técnico da entidade, o aumento se deve ao uso crescente dos meios eletrônicos como forma de pagamento, à falta de uma legislação que iniba o avanço da ação dos criminosos com punições efetivas, e ao descuido de alguns usuários em relação a procedimentos de segurança." (FEBRABAN. Pronunciamentos 19/08/2011: perdas com fraudes eletrônicas aumentam 36\% no primeiro semestre de 2011. Disponível em: <http://www.febraban.org.br/Noticias1.asp?id_texto=1321 $>$. Acesso em: 6 jul. 2012.

209 BRASIL. Presidência da República. Casa Civil. Subchefia para Assuntos Jurídicos. Lei n $n^{\circ}$ 12.737, de 30 de novembro de 2012. Dispõe sobre a tipificação criminal de delitos informáticos; altera o Decreto-Lei no 2.848, de 7 de dezembro de 1940 - Código Penal; e dá outras providências. Disponível em: <http://www.planalto.gov.br/ccivil_03/_Ato2011-2014/2012/Lei/L12737.htm>. Acesso em: 5 dez. 2012. 
como ocorre no crime de furto qualificado, quando há escalada, emprego de chave falsa ou destruição ou rompimento de obstáculo ${ }^{210}$.

Afinal, não são as "portas abertas ou fechadas" que devem definir o objeto de proteção; o que se precisa analisar é a expectativa de privacidade do indivíduo ${ }^{211}$, uma vez que os dados armazenados em um dispositivo eletrônico conectado à rede mundial de computadores são privados, enquanto aqueles que o indivíduo publica em páginas da internet, como blogs e redes sociais, são públicos por opção do próprio usuário.

Por fim, cumpre observar que, apesar de o Código Penal prever causa de aumento de pena para as violações de domicílio praticadas por funcionários públicos fora dos casos previstos em lei ou com inobservância das formalidades legais ou com abuso de poder ${ }^{212}$, nenhuma causa de aumento de pena foi disciplinada para coibir a atuação ilegal de agências de inteligência e da própria polícia judiciária na rede mundial de computadores.

Esse ponto nos parece mais problemático que a própria atuação ilegal nas buscas domiciliares, uma vez que a invasão de dispositivos eletrônicos pode ser realizada sem a percepção do investigado.

Por esse motivo, precisamos repensar os mecanismos jurídicos de proteção e disciplinar o procedimento de buscas e apreensões digitais ${ }^{213}$ — estabelecendo a forma como elas devem ser realizadas para ao mesmo tempo garantir a sua eficiência e resguardar os direitos das pessoas que sofrem a medida restritiva de direitos fundamentais —, além de rever o tipo penal recém-criado, para incluir uma previsão análoga à estabelecida para as violações de domicílio.

210 " $\$ 4^{\circ}$ - A pena é de reclusão de dois a oito anos, e multa, se o crime é cometido: I - com destruição ou rompimento de obstáculo à subtração da coisa; II - com abuso de confiança, ou mediante fraude, escalada ou destreza; III - com emprego de chave falsa; IV - mediante concurso de duas ou mais pessoas."

211 Nos Estados Unidos da América, o primeiro precedente da Suprema Corte que tratou da expectativa de privacidade foi o caso Katz v. United States em 1967 (UNITED STATES. US Supreme Court Center. Katz v. United States - 389 U.S. 347 (1967). Argued 17 Oct. 1967. Decided 18 Dec. 1967. Disponível em: $<$ https://supreme.justia.com/cases/federal/us/389/347/case.html>. Acesso em: 22 ago. 2012).

212 "§ $2^{\circ}$ - Aumenta-se a pena de um terço, se o fato é cometido por funcionário público, fora dos casos legais, ou com inobservância das formalidades estabelecidas em lei, ou com abuso do poder."

213 Em sentido contrário, pela recepção das medidas de busca e apreensão digitais como meios de obtenção de prova atípicos: SOUZA, Diego Fajardo Maranha Leão de. 2007, p. 15. 
Essa nova modalidade de busca e apreensão torna insuficiente a proteção constitucional da casa como forma de estabelecer os limites da atuação estatal, que devem ser pautados pelos princípios que norteiam a proteção da casa, ou seja, pelos princípios da inviolabilidade da intimidade e da vida privada, insculpidos no inciso $\mathrm{X}$ do artigo $5^{\circ}$ da Constituição Federal.

\subsubsection{TEORIA DOS CÍRCULOS CONCÊNTRICOS}

A Constituição Federal de 1988 protegeu de forma expressa, pela primeira vez, a inviolabilidade da intimidade, da vida privada, da honra e da imagem das pessoas, ao estabelecer em seu artigo $5^{\circ}, \mathrm{X}$, que: “[...] são invioláveis a intimidade, a vida privada, a honra e a imagem das pessoas, assegurado o direito a indenização pelo dano material ou moral decorrente de sua violação;”.

Esse princípio constitucional, inserido entre os direitos e garantias fundamentais, tem sua origem próxima na Declaração dos Direitos Humanos aprovada pela Assembléia-Geral da ONU em 1948, que estabeleceu no seu art. 12: "Ninguém será sujeito a interferências na sua vida privada, na sua família, no seu lar, ou na sua correspondência, nem a ataques à sua honra e reputação. Todo homem tem direito à proteção da lei contra tais interferências ou ataques". ${ }^{214,215}$

O princípio foi reproduzido em outros tratados internacionais de direitos humanos, em especial, no artigo 17 do Pacto Internacional sobre os Direitos Civis e Políticos, de $1966^{216}$, e no artigo 11 da Convenção Americana sobre Direitos Humanos (Pacto de São José da Costa Rica), de $1969^{217}$.

214 FERREIRA, Ivette Senise, 1994, p. 97.

215 "Todavia, o direito à intimidade tem origem mais remota, apontando-se a jurisprudência inglesa do século XVIII como o seu berço, embora aparições esporádicas surjam em registros mais antigos. Fato inconteste é que assume inicialmente o caráter de proteção ao domicílio para mais tarde evoluir para outras modalidades. Todos os autores concordam que foi nos Estados Unidos, em fins do século passado, que se estabeleceu a prática verdadeira do 'right of privacy' ou 'right to be let alone' a partir da obra de Warren e Brandeiss - 'The right of privacy', embora o primeiro caso apresentado à Corte Americana tenha sido rejeitado por 4 votos a 3, provocando grande celeuma de opinião pública, que acabou favorecendo a mudança de orientação dos Tribunais naquele país." (FERREIRA, Ivette Senise, 1994, p. 97).

216 “Artigo 17 - 1. Ninguém poderá ser objeto de ingerências arbitrárias ou ilegais em sua vida privada, em sua família, em seu domicílio ou em sua correspondência, nem de ofensas ilegais à sua honra e reputação." (BRASIL. Decreto $n^{\circ}$ 592, de 6 de julho de 1992. Atos Internacionais. Pacto Internacional sobre Direitos Civis e Políticos. Promulgação. Disponível em: <http://www.planalto.gov.br/ccivil_03/ decreto /1990-1994/D0592.htm>. Acesso em: 6 jul. 2012).

217 Art. 11: "1. Toda pessoa tem direito ao respeito de sua honra e ao reconhecimento de sua dignidade. 2. Ninguém pode ser objeto de ingerências arbitrárias ou abusivas em sua vida privada, na de sua família, em seu domicílio ou em sua correspondência, nem de ofensas ilegais à sua honra ou reputação. 3. Toda 
Muito embora as expressões "intimidade" e "vida privada" tenham sido utilizadas indiferentemente pela doutrina brasileira, as distinções fundamentais já foram destacadas por diversos autores que elaboraram estudos sobre o tema, tendo como precursores os professores Paulo José da Costa Jr. ${ }^{218}$, René Ariel Dotti ${ }^{219}$ e Ada Pellegrini Grinover ${ }^{220}$.

A vida privada compreende todos os acontecimentos que o indivíduo não deseja que sejam de domínio público e que são de conhecimento de um círculo determinado de pessoas com quem mantém relações de amizade e trabalho. Já a intimidade compreende os acontecimentos e as conversas íntimas compartilhados com as pessoas com quem o indivíduo mantém relações de intimidade ou confiança e os segredos, que muitas vezes não são compartilhados com nenhuma pessoa, ou apenas com confidentes.

Paulo José da Costa Jr., embasado no trabalho de Henkel, desenvolveu entre nós a Teoria dos Círculos Concêntricos ${ }^{221}$, segundo a qual o indivíduo desenvolve sua personalidade entre duas esferas. A primeira esfera, individual (Individualsphare), compreenderia todas as atividades realizadas em sociedade ou como partícipe do consórcio humano $^{222} \mathrm{e}$, portanto, de domínio público, e nela estariam compreendidos o nome, a imagem e a reputação. A segunda, privada (Privatsphare), se subdividiria em três esferas concêntricas $^{223}$.

A primeira delas, mais ampla, é a esfera privada, que corresponderia à vida privada do indivíduo, em que ele pode exercer seus interesses por uma existência livre e que é protegida de indiscrições ou de conhecimento do público em geral. Na segunda esfera, da intimidade (Vertrauensphare), encontram-se todos os acontecimentos íntimos,

pessoa tem direito à proteção da lei contra tais ingerências ou tais ofensas." (BRASIL. Decreto $n^{\circ} 678$, de 6 de novembro de 1992. Promulga a Convenção Americana sobre Direitos Humanos (Pacto de São José da Costa Rica), de 22 de novembro de 1969. Disponível em: <http://www.planalto.gov.br/ccivil_03/ decreto/D0678.htm>. Acesso em: 6 jul. 2012).

218 COSTA JR., Paulo José. O direito de estar só. 4. ed. São Paulo: Revista dos Tribunais, 2007.

219 DOTTI, René Ariel. Proteção da vida privada e liberdade de informação: possibilidades e limites. São Paulo: Revista dos Tribunais, 1980.

220 GRINOVER, Ada Pellegrini. Liberdades públicas e processo penal: as interceptações telefônicas. 2. ed. São Paulo: Revista dos Tribunais, 1982.

221 COSTA JR., Paulo José, 2007, p. 20-31.

222 FERREIRA, Ivette Senise, 1994, p. 99.

223 Cf. COSTA JR., Paulo José, 2007, p. 24. 
compartilhados com as pessoas com quem o indivíduo mantém relações mais íntimas ou de certa confiança ${ }^{224}$.

Por fim, a menor das esferas seria a do segredo (Geheimsphare), que compreende uma parcela da intimidade restrita ao próprio indivíduo ou a pessoas de sua extrema confiança $^{225}$. Cumpre aqui observar que, a nosso ver, determinadas atividades estariam abrangidas pela esfera do segredo, como o diário íntimo, as consultas psicológicas e psiquiátricas, as confissões a sacerdotes e as informações fornecidas aos advogados necessárias à defesa dos interesses do indivíduo ${ }^{226}$.

Por esse motivo, ao repensarmos os limites da busca e da apreensão no presente trabalho, uma vez que a proteção da casa não é suficiente para abranger as novas hipóteses de varejamento por meios eletrônicos, é importante observar que nessa busca, seja pessoal, seja domiciliar, seja digital, estaremos seguramente varejando a vida privada e a intimidade do investigado.

Por outro lado, não podemos permitir que sejam apreendidos quaisquer elementos que atinjam a esfera de segredo do indivíduo, pois estaríamos devassando informações que só poderiam ser obtidas mediante tortura ou outra forma de redução da capacidade de resistência do indivíduo.

Da mesma forma, não podem ser apreendidos quaisquer documentos ou dados documentados em função das atividades que se encontram na esfera do segredo, em especial as consultas médicas, as confissões sacerdotais e as informações fornecidas aos advogados, sob pena de esvaziamento das atividades e violação da esfera de segredo do investigado ou da esfera indevassável da intimidade.

224 Cf. COSTA JR., Paulo José, 2007, p. 29-30.

${ }^{225}$ Cf. COSTA JR., Paulo José, 2007, p. 31.

${ }^{226}$ Nesse sentido: ALMEIDA, José Raul Gavião de. Anotações acerca do direito à privacidade. In: MIRANDA, Jorge; SILVA, Marco Antônio Marques da. (Org.). Visão luso-brasileira da dignidade humana. São Paulo: Quartier Latin, 2008. v. 1. p. 677. 


\subsection{A BUSCA E A APREENSÃo NO DIREITO COMPARADO}

O presente estudo está circunscrito ao processo penal brasileiro, todavia, uma vez que ainda verificamos o tratamento da busca e da apreensão como um só instituto por parte da doutrina e da jurisprudência brasileira, entendemos por bem utilizar como suporte ao presente estudo uma breve análise do direito comparado.

Em especial, vamos abordar as buscas e as apreensões nos ordenamentos jurídicos estadunidense, argentino e italiano. O primeiro se justifica porque é o berço da doutrina do direito de estar só, ou seja, o "right of privacy" ou "right to be let alone", desenvolvido com base na obra de Warren e Brandeiss "The right of privacy", publicada em $1890^{227}$.

Em seguida, abordaremos o sistema processual penal argentino, restringindo o estudo ao Código Processual Penal argentino, sem abordar os códigos processuais penais das províncias. Entretanto, é importante destacar que verificamos que o Código de Processo Penal da província de Córdoba ${ }^{228}$ tem dispositivos análogos aos previstos na legislação nacional, tanto para as buscas quanto para as apreensões.

A escolha da legislação processual penal argentina para a análise de direito comparado decorre, primeiro, da proximidade geográfica, econômica e cultural existente entre o Brasil e a Argentina e segundo, do fato de, na legislação processual penal argentina, a apreensão, apesar de ter matriz constitucional muito parecida com a brasileira, estar disciplinada e ser entendida como um instituto autônomo em relação à busca.

Por fim, vamos fazer uma breve análise do sistema processual penal italiano, primeiro porque a legislação italiana revogada serviu de inspiração ao nosso Código de Processo Penal vigente e segundo porque aquele sistema já sofreu uma completa revisão, atualizando a legislação aos novos paradigmas constitucionais e às novas necessidades do processo penal contemporâneo.

227 FERREIRA, Ivette Senise, 1994, p. 97.

228 ARGENTINA. El Senado y la Cámara Dediputados de la Provincia de Córdoba. Ley: $N^{o}$ 8.123. Disponível em: <http:/web2.cba.gov.ar/web/leyes.nsf/85a69a561f9ea43d03257234006a8594/2e112b5a1 d5642dc0325723400642019?OpenDocument>. Acesso em: 5 jan. 2013. 
Ademais, o sistema processual penal italiano tem uma divisão muito marcada entre os institutos da inspeção judicial — busca, apreensão e sequestro —, delimitando de forma clara a função de cada medida prevista no sistema processual penal, o que nos facilitará a compreensão de que a busca e a apreensão são institutos com natureza jurídica diversa.

Assim, poderemos restringir o presente estudo a seu efetivo objeto, passando a tratar apenas das medidas de apreensão previstas na legislação vigente e na legislação projetada para o novo código de processo penal brasileiro.

\subsubsection{A BUSCA E APREENSÃO NO DIREITO PROCESSUAL PENAL ESTADUNIDENSE}

O sistema processual penal estadunidense também disciplinou as buscas em conjunto com as apreensões, sendo a disposição legal mais importante do sistema sobre as buscas e as apreensões a prevista na quarta emenda da Constituição dos Estados Unidos da América $^{229}$.

Segundo o previsto na quarta emenda, são invioláveis as pessoas, as casas, os papéis e os haveres, não estando sujeitos a buscas e apreensões arbitrárias. Nenhum mandado de busca e apreensão será expedido senão mediante indícios de culpabilidade confirmados por juramento ou declarações, devendo o mandado descrever o local, as pessoas e as coisas que devem ser apreendidas ${ }^{230}$.

A quarta emenda traz consigo duas disciplinas importantes: a cláusula da razoabilidade e a cláusula do mandado. A cláusula da razoabilidade estabelece que o povo está livre das buscas e apreensões desarrazoadas, enquanto a cláusula do mandado estabelece que as buscas e as apreensões devem ser determinadas por mandado judicial

${ }^{229}$ UNITED STATES. National Archives. Official Bill of Rights. New York. 4 Mar. 1789. Disponível em: $<$ http://www.archives.gov/exhibits/charters/bill_of_rights_transcript.html >. Acesso em: 22 ago. 2012.

230 "Amendment IV. The right of the people to be secure in their persons, houses, papers, and effects, against unreasonable searches and seizures, shall not be violated, and no Warrants shall issue, but upon probable cause, supported by Oath or affirmation, and particularly describing the place to be searched, and the persons or things to be seized." (UNITED STATES, 1789). 
contendo a causa provável e a particular descrição do local a ser buscado e das coisas a serem $_{\text {apreendidas }}{ }^{231}$.

Além disso, devem estar presentes os pressupostos de necessidade e urgência, consistentes no risco de dispersão, alteração e eliminação da prova no tempo necessário para obtê-la. Com base nessas disposições, seria lógico concluir que a autoridade policial deveria descrever as coisas que pretende apreender para a expedição do mandado de busca e apreensão e que, por outro lado, a apreensão estaria restrita às coisas descritas no mandado expedido.

Entretanto, não é essa a interpretação da Suprema Corte dos Estados Unidos, que decidiu, no caso Andresen v. Maryland (427 US 463 - 1976), que a autoridade policial pode apreender coisas que não constam do mandado, desde que relacionadas com o crime que motivou a expedição da medida ${ }^{232,233}$.

Os mandados de busca e apreensão devem necessariamente ser requeridos por autoridades policiais, ou seja, os particulares não podem requerer ou exigir esses mandados, como ocorre no Brasil, no procedimento previsto para os crimes contra a propriedade imaterial de ação penal de iniciativa privada. Além disso, como o sistema estadunidense também divide o judiciário em âmbitos federal e estaduais, as autoridades policiais devem requerer os mandados às respectivas esferas de justiça ${ }^{234}$.

Antes de utilizar-se da força para adentrar no local da busca e cumprir o disposto no mandado de busca e apreensão, as autoridades policiais devem anunciar-se, qualificar-se, declarar a finalidade de sua presença no local da busca e apreensão e aguardar que o residente lhe franqueie a presença ${ }^{235}$.

${ }^{231}$ RAMOS, João Gualberto Garcez. Curso de processo penal norte-americano. São Paulo: Revista dos Tribunais, 2006. p. 127. Ver íntegra em: UNITED STATES. US Supreme Court Center. Andresen v. Maryland - 427 U.S. 463 (1976). Argued 25 Feb. 1976. Decided 29 Jun. 1976. Disponível em: $<$ http://supreme.justia.com/cases/federal/us/427/463/case.html>. Acesso em: 22 ago. 2012.

${ }^{232}$ RAMOS, João Gualberto Garcez, 2006, p. 132.

${ }^{233}$ Cumpre observar que a Suprema Corte Norte-Americana já se pronunciou no sentido de que a busca e a apreensão dispensam a expedição de mandado quando há o prévio consentimento do interessado permitindo a entrada da autoridade policial para a realização da medida.

234 AMODIO, Enio; BASSIOUNI, M. Cherif. Il processo penale negli stati uniti d'America. Milano; Giuffrè, 1988. p. 84.

${ }^{235}$ AMODIO, Enio; BASSIOUNI, M. Cherif, 1988, p. 85. 
As apreensões, no direito processual penal estadunidense, têm como escopo apreender os instrumentos utilizados para a prática do crime, as coisas obtidas como produto ou resultado da prática criminosa e todas as provas úteis ao processo. Por tal motivo a disciplina da quarta emenda era entendida como a proteção ao direito de propriedade do indivíduo.

Entretanto, a proteção da quarta emenda não se restringe a buscas e apreensões físicas na residência do investigado ou de terceiros; abrange também as comunicações telefônicas, as comunicações eletrônicas e as comunicações entre presentes. Dessa forma, a própria interpretação da Suprema Corte Norte-Americana sobre o conteúdo e a extensão da garantia prevista na quarta emenda evoluiu.

A disciplina das buscas e das apreensões reguladas pela quarta emenda inicialmente visava proteger a propriedade privada dos indivíduos segundo a doutrina do castelo, de acordo com a qual o proprietário de determinado domicílio era seu senhor e soberano. Tal teoria perdurou até o precedente Katz v. United States (389 US 347 1967), a partir do qual essa disciplina passou a ser regulada pela teoria da expectativa de privacidade.

Entretanto, após os atentados de 11 de setembro de 2001, o Congresso NorteAmericano promulgou um ato controverso denominado "Patriot Act", sancionado pelo presidente George W. Bush em 26 de outubro de $2001^{236}$.

Dentre as várias medidas controversas, foram introduzidas as denominadas “diligências secretas", por meio das quais as autoridades policiais passaram a poder realizar — mediante autorização judicial — diligências secretas em residências e escritórios para instalar câmeras e microfones e gravar clandestinamente as conversas ${ }^{237}$.

${ }^{236}$ UNITED STATES. Uniting and strengthening America by providing appropriate tools required to intercept and obstruct terrorism (Usa Patriot Act) Act of 2001. Disponível em: $<$ http://www.gpo.gov/fdsys/pkg/PLAW-107publ56/html/PLAW-107publ56.htm>. Acesso em: 22 ago. 2012.

${ }^{237}$ BECHARA, Fábio Ramazzini; MANZANO, Luís Fernando de Moraes. Crime organizado e terrorismo nos Estados Unidos da América. In: FERNANDES, Antonio Scarance; ALMEIDA, José Raul Gavião de; MORAES, Maurício Zanoide de. (Orgs.). Crime organizado: aspectos processuais. São Paulo: Revista dos Tribunais, 2009. p. 153-184. p. 180. 
Em relação à apreensão de produtos contrafeitos, o Digital Millenium Copyright $\mathrm{Act}^{238}$ (DMCA) modificou as disposições do Copyright $\mathrm{Act}^{239}$, introduzindo um capítulo sobre medidas de proteção tecnológicas e sistemas de informação.

Além das apreensões de todos os produtos contrafeitos, como medida de efetividade no processo penal estadunidense, a nova regulamentação estende a proteção penal para proibir a violação de sistemas de identificação de cópia e sistemas anticópia, entretanto as buscas e as apreensões digitais também não foram disciplinadas naquele sistema.

\subsubsection{A BUSCA E A APREENSÃo NO DIREITO PROCESSUAL PENAL ARGENTINO}

No direito processual penal argentino a disciplina da busca está separada da disciplina da apreensão, apesar de a matriz constitucional as prever em conjunto, como no Brasil, estabelecendo parâmetros de proteção pautados principalmente na cláusula da inviolabilidade do domicílio. No artigo 18 da Constitución Nacional argentina é assegurada a inviolabilidade do domicílio, da correspondência epistolar e dos papéis privados, determinando que uma norma infraconstitucional estabelecerá os casos e os fundamentos que permitirão as buscas e a ocupação do domicílio ${ }^{240}$.

Segundo Julio Maier, a garantia estabelecida no artigo 18 da Constituição argentina impõe que uma lei específica editada pelo Congresso argentino determinaria quais requisitos e condições deveriam ser obedecidos para que uma busca em um domicílio ou em um local fechado fosse considerada legal ${ }^{241}$.

${ }^{238}$ UNITED STATES. The Digital Millennium Copyright Act of 1998. Disponível em: $<$ http://www.copyright.gov/title17/92appb.pdf >. Acesso em: 26 ago. 2012.

${ }^{239}$ UNITED STATES. The Copyright Act of 1976. Disponível em: <http://www.copyright.gov/title17/ 92appa.pdf $>$. Acesso em: 26 ago. 2012.

240 "El domicilio es inviolable, como también la correspondencia epistolar y los papeles privados; y una ley determinará en qué casos y con qué justificativos podrá procederse a su allanamiento y ocupación." (ARGENTINA. Senado de la Nación Argentina. Constitución Nacional. Santa Fe, 22 ago. 1994a. Disponível em: <http://www.senado.gov.ar/web/interes/constitucion/cuerpo1.php>. Acesso em: 8 set. 2012).

${ }^{241}$ MAIER, Julio B. J. Derecho procesal penal: fundamentos. 2. ed. 3. reimp. Buenos Aires: Editores Del Puerto, 2004. p. 681. 
O Código Procesal Penal argentino, Lei $n^{\circ} 23.984$ de $1991^{242}$, é a norma infraconstitucional que estabelece as regras para as buscas e as apreensões prevista no texto constitucional. O Código Procesal Penal argentino trata, em seu título II, capítulo II, do "allanamiento", consistente no ato de ingresso no domicílio, e, em seguida, do "registro domiciliário" e da "requisa personal", consistentes na busca domiciliar e pessoal, respectivamente. No capítulo seguinte, está disciplinada a apreensão, que, no direito processual penal argentino, é denominada "secuestro".

\subsubsection{A BUSCA NO DIREITO ARGENTINO}

O allanamiento é uma modalidade específica de busca realizada em domicílios e em locais fechados, na qual prevalece a proteção da intimidade da pessoa. Exceto em casos de allanamiento, a pessoa tem o direito de impedir a entrada de qualquer sujeito privado ou autoridade pública.

O artigo 224 do Código Procesal Penal argentino estabelece que a medida de allanamiento deve ser determinada por ordem judicial motivada, e Cafferata Nores ressalta que não basta que a ordem seja judicial e motivada, mas que também é necessário que a fundamentação justifique a necessidade e a proporcionalidade da medida ${ }^{243}$.

A medida de allanamiento, em regra, deve ser executada pelo próprio magistrado, auxiliado por seus funcionários. Entretanto, o magistrado pode delegar a realização ao ministério público ou às autoridades policiais, e, nesses casos, a ordem deverá conter a indicação do lugar, da finalidade, da autoridade que realizará o ato, para evitar a "orden de allanamiento en blanco".

O conceito de domicílio, para os casos de allanamiento, deve ser interpretado de forma ampla, abrangendo outros locais, como estabelecimentos de reunião, escritórios,

${ }^{242}$ ARGENTINA. Senado y Cámara de Diputados de la Nación Argentina. Código Procesal Penal. 4 set. 1991. Disponível em: <http://www.infoleg.gov.ar/infolegInternet/anexos/0-4999/383/texact.htm\#9>. Acesso em: 08 set. 2012.

${ }^{243}$ CAFFERATA NORES, José Ignacio; HARAIBEDIÁN, Maximiliano. La prueba em el proceso penal: com especial referencia a los Códigos PPN y de la província de Córdoba. 6. ed. Buenos Aires: Lexis Nexis Argentina, 2008. p. 237. 
associações e outros lugares fechados, na forma dos artigos 225 e 226 do Código Procesal Penal argentino.

Cabe ressaltar que no sistema processual penal argentino a qualidade de local fechado não é suficiente para impor a necessidade de ordem de allanamiento, visto que, além de fechado, o local deve estar protegido pelo direito de propriedade, pela inviolabilidade do domicílio ou pela inviolabilidade da intimidade ${ }^{244}$.

A primeira exceção admitida no sistema processual penal argentino à necessidade de ordem judicial para a realização de allanamiento são os casos de incêndio, explosão, inundação ou outras ameaças que coloquem em risco a vida dos habitantes ou a propriedade ${ }^{245}$. A segunda exceção, na forma do inciso $2^{\circ}$ do artigo 227 do Código Procesal Penal argentino, são os casos de pessoas estranhas vistas invadindo o local com indícios manifestos de que vão cometer um delito. E a terceira inclui casos em que haja pedido de socorro ou em que forem ouvidas vozes que permitam inferir que ali está ocorrendo um crime, na forma do inciso $4^{\circ}$ do mesmo dispositivo.

Por fim, existem duas exceções, que são as hipóteses de allanamiento em casos de crimes com pena máxima superior a três anos, para realizar prisão em flagrante ou por mandado de prisão (art. 227, $3^{\circ}$, do Código Procesal Penal argentino), e a exceção criada pela Lei $\mathrm{n}^{\mathrm{o}} 25.760^{246}$, que estabelece a possibilidade de allanamiento em casos de sequestro de pessoas, sendo exigida a presença do ministério público.

A primeira limitação ao poder de allanar é a estabelecida no artigo 226 do Código Procesal Penal argentino, que exige autorização do presidente da casa legislativa para a entrada no congresso nacional ou na legislatura. A mesma autorização é necessária para

\footnotetext{
${ }^{244}$ Segundo Cafferata Nores, as celas prisionais ocupadas também preenchem todos os requisitos para a proteção constitucional do domicílio e da intimidade e, por tal motivo, também deveriam ser objeto de ordem de allanamiento, a despeito das previsões na legislação de execução penal que autorizam as buscas pela autoridade penitenciária sem qualquer ordem judicial (CAFFERATA NORES, José Ignacio; HARAIBEDIÁN, Maximiliano, 2008, p. 237).

${ }^{245}$ Inciso $1^{\circ}$ do artigo 227 do Código de Processo Penal argentino. (ARGENTINA, 1991).

${ }^{246}$ ARGENTINA. Ley 25.760. Disponível em: <http://infoleg.gov.ar/infolegInternet/anexos/85000-89999/ 87494/norma.htm>. Acesso em: 8 ago. 2012.
} 
realizar o allanamiento no domicílio particular e no escritório de algum legislador nacional, na forma do artigo $1^{\circ}$ da Lei $n^{\mathrm{o}} 25.320^{247}$.

Outra restrição é a obrigação do tribunal de informar a ordem dos advogados antes de proceder a um allanamiento no escritório de qualquer advogado, na forma do artigo $7^{\circ}$ da Lei $\mathrm{n}^{\mathrm{o}} 23.187^{248}$, que poderá acompanhar sua realização. A falta de aviso acarreta na nulidade do ato.

Vistos os requisitos e as limitações do allanamiento, passaremos agora a observar o procedimento a ser seguido. O artigo 225 do Código Procesal Penal argentino estabelece que o allanamiento deve ser realizado em horário diurno, compreendido entre o nascer e o pôr do sol, e que tal obrigação se restringe aos domicílios, não se estendendo aos edifícios públicos, aos escritórios, às associações, etc. As exceções são os casos graves e urgentes, os casos em que há perigo para a ordem pública e os casos nos quais haja consentimento do interessado ou de seu representante.

A ordem de allanamiento deve ser exibida ao proprietário ou possuidor do local no qual será realizada a diligência, que será convidado a acompanhar todo o procedimento. Quando o local estiver desabitado, ou quando no momento da diligência não estiver ocupado, tal circunstância será descrita em ata e o allanamiento será realizado.

Ademais, conforme previsão expressa do artigo 228 do Código Procesal Penal argentino, o receptor da ordem judicial deve ser individualizado e notificado, para que o ato de apreensão tenha validade. Se o receptor da ordem estiver ausente no momento da realização da medida e da respectiva notificação, pode ser notificado um representante legal do destinatário ou qualquer pessoa maior de idade que estiver no local naquele momento, de preferência os familiares do receptor. Quando a ordem judicial for dirigida para mais de um receptor no mesmo domicílio, basta a notificação de um deles para o cumprimento do ato. A exceção prevista para a formalidade de notificação são situações nas quais o conhecimento da busca e da apreensão pelo receptor possa prejudicar os

\footnotetext{
${ }^{247}$ ARGENTINA. Ley 25.320. Ley de fueros. Disponível em: < http://infoleg.gov.ar/infolegInternet/anexos/ 60000-64999/64286/norma.htm>. Acesso em: 8 ago. 2012.

248 ARGENTINA. Abogacia. Requisitos para el ejercicio de la profesión de abogado en la Capital Federal, Jerarquía, deberes y derechos, Matrícula. Colegiación. Disponível em: <http://www.infoleg.gov.ar/ infolegInternet/anexos/25000-29999/26188/texact.htm>. Acesso em: 8 ago. 2012.
} 
propósitos do ato, sendo dispensada a notificação nos termos do artigo 226 do Código Procesal Penal argentino.

O artigo 200 do Código Procesal Penal argentino estabelece que os defensores das partes têm direito de acompanhar o ato, entretanto não se exige a notificação prévia destes para não frustrar os resultados da medida.

\subsubsection{A APREENSÃO NO DIREITO ARGENTINO}

O secuestro é o ato de apreensão do bem pela autoridade judicial por meio do qual é realizada a constrição do patrimônio do investigado e a indisponibilização temporária do bem, com a finalidade de assegurar o cumprimento da sua função específica no processo penal: investigação da verdade e correta aplicação da lei penal ${ }^{249}$.

Sendo assim, o secuestro, no direito processual penal argentino, é meio de obtenção de prova, consistente em um ato de coerção real, cautelar e provisória, realizado pela polícia judiciária para se apropriar de objetos, documentos e coisas relacionadas com o delito, os quais possam ser úteis ao "thema probandum".

Como no sistema brasileiro, as apreensões prescindem de mandado específico que normalmente autoriza as buscas domiciliares e as buscas pessoais, conforme o disposto no inciso I do artigo 230 bis do Código Procesal Penal argentino. Entretanto, naquele sistema o mandado deve identificar os objetos que podem ser apreendidos, e os demais objetos não previstos na ordem judicial só podem ser apreendidos se tiverem relação com o delito, devendo o executor informar o juiz e o ministério público logo após a realização da apreensão, conforme dispõe o artigo 231 do mesmo diploma legal ${ }^{250}$.

${ }^{249}$ Cf. CLARIÁ OLMEDO, Jorge A, Tratado de derecho procesal penal. Buenos Aires: Ediar, 1966. tomo 5. p. 377.

250 “Art. 231. - El juez podrá disponer el secuestro de las cosas relacionadas con el delito, las sujetas a decomiso o aquellas que puedan servir como medios de prueba. Sin embargo, esta medida será dispuesta y cumplida por los funcionarios de la policía o de las fuerzas de seguridad, cuando el hallazgo de esas cosas fuera resultado de un allanamiento o de una requisa personal o inspección en los términos del artículo 230 bis, dejando, constancia de ello en el acta respectiva y dando cuenta inmediata del procedimiento realizado al juez o al fiscal intervinientes." 
De acordo com o artigo 224 do Código Procesal Penal argentino, para serem válidas, as ordens judiciais de buscas e apreensões devem ser escritas e fundamentadas e determinar o local, o objeto e o horário em que serão realizadas. As medidas devem ser outorgadas por juiz competente e levadas a cabo por um funcionário público ou "agente de autoridade" competente para realizar o allanamiento ou o "registro domiciliário".

O artigo 231 do mesmo diploma legal determina que são passíveis de apreensão todos os objetos relacionados ao delito, os objetos sujeitos a confisco e os objetos que possam servir como elemento de prova no processo criminal.

Não são passiveis de apreensão os documentos com conteúdo político ou militar relacionados à segurança do país, na forma do artigo 232, as correspondências de advogados com seus clientes, relacionadas ao sigilo profissional e ao exercício dos direitos de defesa, conforme o artigo 237, e todos os demais objetos que não se enquadrem no rol do artigo 231.

De acordo com o artigo 233 do Código de Procesal Penal argentino, os bens apreendidos devem ser inventariados, lacrados com selo do Tribunal assinado pelo juiz, de forma que lhes assegure a inviolabilidade. O juiz poderá, também, determinar extração de cópias e reproduções dos bens apreendidos, quando estes puderem desaparecer, modificarse ou desintegrar-se ou quando for conveniente para a instrução criminal.

Os objetos apreendidos que não possuam importância para o processo e que não estejam submetidos às medidas de confisco ou embargo devem ser devolvidos para aquele que os possuía no momento da apreensão, conforme o artigo 238 do Código de Processo Penal $^{251}$. A devolução pode ser determinada de modo definitivo, sem qualquer encargo ao possuidor, ou de modo provisório, na forma de depósito, obrigando-se o possuidor a exibir os objetos quando assim exigido pelo juiz.

251 A Lei $\mathrm{n}^{\circ}$ 20.785, de 11 de outubro de 1974, prevê que durante o curso do processo os títulos e os valores apreendidos serão depositados no banco da cidade de Buenos Aires ou no Banco da Nação Argentina, os entorpecentes serão confiados aos órgãos governamentais responsáveis, as armas de fogo e os explosivos serão encaminhados ao exército e as aeronaves, à aeronáutica. (ARGENTINA. Senado y Cámara de Diputados de la Nación Argentina. Ley $n^{\circ}$ 20.785. Bienes objeto de secuestro en causas penales. Custodia y disposición. Buenos Aires, 26 sep. 1974. Disponível em: <http://www.infoleg.gov.ar/infolegInternet/ anexos/135000-139999/136925/texact.htm>. Acesso em: 8 set. 2012). 
Os bens apreendidos que tenham sido objeto de subtração serão devolvidos aos reais proprietários, diretamente prejudicados pela ação delituosa, salvo quando houver oposição do possuidor de boa-fé, em cujo poder se encontravam ao tempo da apreensão.

O inciso IV do artigo 224 do Código Procesal Penal argentino permite que durante o cumprimento de ordem de busca sejam apreendidos objetos que evidenciem o cometimento de delito diverso daquele para o qual a ordem foi expedida, devendo se proceder à respectiva apreensão, além da imediata comunicação ao juiz e ao ministério público.

Também são lícitas as buscas realizadas sem ordem judicial, na forma do artigo 227 do Código Procesal Penal argentino, quando realizadas em situações em que haja perigo à vida dos moradores, perseguição a criminoso ou suspeita de que no local exista vítima de privação ilegal da liberdade.

Por fim, o artigo 228 do Código de Procesal Penal argentino determina que ao final da diligência será lavrada uma ata com a descrição de todos os atos praticados e o detalhamento dos elementos úteis à investigação.

As apreensões, no caso dos crimes contra a propriedade intelectual também estão sujeitas, no direito processual penal argentino, a regras previstas na lei de propriedade intelectual (Lei $\mathrm{n}^{\mathrm{o}} 11.723^{252}$ ), alterada em 1998 pela Lei $\mathrm{n}^{\mathrm{o}} 25.036^{253}$, que estendeu a proteção aos programas de computador.

No artigo 72 bis da Lei $n^{0} 11.723$, acrescido pela Lei $n^{\circ} 23.741$ de $1989^{254}$, ficou estabelecido que o titular dos direitos intelectuais poderá solicitar ao juiz comercial ou penal a apreensão tanto das cópias do fonograma reproduzidas ilicitamente quanto dos objetos de reprodução. O juiz poderá determinar que o requerente preste caução quando entender que ele careça de responsabilidade patrimonial, salvo quando a medida for

${ }^{252}$ ARGENTINA. Ley 11.723 - Regimen Legal de la Propiedad Intelectual. Disponível em: $<$ http://infoleg.mecon.gov.ar/infolegInternet/anexos/40000-44999/42755/texact.htm>. Acesso em: 8 set. 2012.

${ }^{253}$ ARGENTINA. Ley 25.036 - Modifícanse los artículos $1^{\circ}, 4^{\circ}, 9^{\circ}$ y 57 e incorpórase el artículo 55 bis a la Ley $\mathrm{N}^{\circ}$ 11.723. Disponível em: <http://infoleg.mecon.gov.ar/infolegInternet/anexos/50000-54999/54178/ norma.htm>. Acesso em: 8 set. 2012.

${ }^{254}$ ARGENTINA. Ley 23.741 - Modifícase la Ley $\mathrm{N}^{\circ}$ 11.723. Disponível em: http://infoleg.mecon.gov.ar/infolegInternet/anexos/0-4999/142/norma.htm. Acesso em: 8 set. 2012. 
requerida por associações de autores ou produtores cuja representatividade seja legalmente reconhecida ${ }^{255}$.

Dessa forma, também estão previstas no sistema processual penal argentino, por força das pressões internacionais ${ }^{256}$ e da recepção do TRIPs pela Lei $n^{0} 24.425^{257}$, as apreensões tanto civis quanto penais para todos os bens ilicitamente reproduzidos, como forma de combate à pirataria.

\subsubsection{A BUSCA E A APREENSÃO NO DIREITO PROCESSUAL PENAL ITALIANO}

No sistema processual penal italiano, os meios de obtenção de prova estão disciplinados no título III ("Mezzi di ricerca della prova") do livro III do Códice di Procedura Penale italiano ${ }^{258}$, nos artigos 244 a 271.

Pelos meios de obtenção de prova são adquiridos elementos probatórios preexistentes a realização do próprio meio. Segundo Paolo Tonini, os meios de obtenção de prova se baseiam, de regra, no elemento surpresa, pois não contam com o aviso prévio ao defensor do investigado quando realizados na fase das investigações ${ }^{259}$.

255 "El damnificado podrá solicitar en jurisdicción comercial o penal el secuestro de las copias de fonograma reproducidas ilícitamente y de los elementos de reproducción. El juez podrá ordenar esta medida de oficio, así como requerir caución suficiente al peticionario cuando estime que éste carezca de responsabilidad patrimonial. Cuando la medida precautoria haya sido solicitada por una sociedad autoral o de productores, cuya representatividad haya sido reconocida legalmente, no se requerirá caución." (ARGENTINA. Ley 11.723. Regimen Legal de la Propiedad Intelectual. Buenos Aires, 26 sep. 1933. Disponível em: <http://infoleg.mecon.gov.ar/infolegInternet/anexos/40000-44999/42755/texact.htm>. Acesso em: 8 set. 2012).

${ }^{256}$ Cumpre ressaltar que o discurso do combate à pirataria é uníssono em todo o mundo e visivelmente manipulado por dados levantado pelas empresas interessadas na maior intervenção do Estado no setor, senão vejamos: "Price-Waterhouse ha indicado que conforme el relevamiento de datos correspondientes a 1997 en nuestro país, el mercado de software ilegal llegó a unos 559 millones de dólares, estimándose en términos ideales que las pérdidas del sector habrían sido de unos 1.300 millones de la misma moneda." (RIQUERT, Marcelo Alfredo. Comentario de la ley 25.036 de protección penal del software. Cuadernos de doctrina y jurisprudencia penal, Ano 5, v. 8-c, Buenos Aires: Ad Hoc, p. 633/655, 1999. p. 651-652).

257 ARGENTINA. Senado y Cámara de Diputados de la Nación Argentina. Ley $n^{\circ} 24.425$. Apruébase el acta final en que se incorporan los resultados de la Ronda Uruguay de Negociaciones Comerciales Multilaterales; las decisiones, declaraciones y entendimiento ministeriales y el Acuerdo de Marrakesh. Buenos Aires, 7 dez. 1994b. Disponível em: <http://www.infoleg.gov.ar/infolegInternet/anexos/04999/799/norma.htm>. Acesso em: 8 set. 2012.

258 ITALIA. Decreto del presidente della Repubblica 22 settembre 1988, n. 447. Códice di Procedura Penale (GU n.250 del 24-10-1988 - Suppl. Ordinario n. 92). Disponível em: <http://www.normattiva.it/urires/N2Ls?urn:nir:stato:decreto.presidente.repubblica:1988-9-22;447!vig=>. Acesso em: 22 ago. 2012.

259 TONINI, Paolo, Manuale di procedura penale. 8. ed. Milano: Dott. A. Giuffrè, 2007. p. 320. 
Os meios de obtenção de prova típicos previstos e disciplinados no Códice di Procedura Penale italiano são as inspeções, as buscas, as apreensões e as interceptações de conversações e comunicações ${ }^{260}$.

\subsubsection{A INSPEÇÃO NO DIREITO ITALIANO}

A inspeção no processo penal italiano está disciplinada nos artigos 244 a 246 do Códice di Procedura Penale italiano e se subdivide em inspeções pessoais (art. 245) e inspeções de coisas ou lugares (art. 246).

As inspeções (ispezione) são meios de obtenção de prova que possibilitam a averiguação dos vestígios materiais do delito. Tal meio de obtenção de prova se caracteriza principalmente pela descrição de pessoas, lugares e coisas submetidas às inspeções ${ }^{261}$.

Em regra o sistema processual penal italiano impõe que as inspeções sejam precedidas de ordem judicial motivada, entretanto, conforme dispõe o artigo $364^{262}$ do mesmo diploma legal, as inspeções podem ser realizadas pelo ministério público sem ordem judicial motivada, desde que assegurada a defesa do investigado.

Outro requisito da medida determina que antes da execução da inspeção o investigado ou a pessoa que detenha a posse do local ou da coisa a ser inspecionada receba uma cópia do mandado que autoriza a medida.

Quando necessário, o decreto que determina a execução da medida pode autorizar a realização de operações técnicas sobre o local ou a coisa a ser inspecionada, na forma do

${ }^{260}$ No presente trabalho adotamos a sistematização terminológica desenvolvida por Antonio Magalhães Gomes Filho, adaptando-a, e por tal motivo substituímos a expressão "meios de busca da prova", utilizada pelo legislador italiano, pela expressão "meio de obtenção de prova" (GOMES FILHO, Antonio Magalhães. Notas sobre a terminologia da prova (reflexos no processo penal brasileiro). In: YARSHELL, Flávio Luiz; MORAES, Maurício Zanoide (Orgs.). Estudos em homenagem à professora Ada Pellegrini Grinover. São Paulo: DPJ, 2005. p. 303-318).

261 TONINI, Paolo. A prova no processo penal italiano. São Paulo: Revista dos Tribunais, 2002. p. 243.

262 “Art. 364.5. Nei casi di assoluta urgenza, quando vi è fondato motivo di ritenere che il ritardo possa pregiudicare la ricerca o l'assicurazione delle fonti di prova, il pubblico ministero può procedere a interrogatorio, a ispezione o a confronto anche prima del termine fissato dandone avviso al difensore senza ritardo e comunque tempestivamente. L'avviso può essere omesso quando il pubblico ministero procede a ispezione e vi è fondato motivo di ritenere che le tracce o gli altri effetti materiali del reato possano essere alterati. E' fatta salva, in ogni caso, la facoltà del difensore d'intervenire.”. 
artigo 244 do Códice di Procedura Penale italiano; e, da mesma forma, o magistrado pode dispor de meios fotográficos e outros meios análogos para registrar a realização da medida ${ }^{263}$.

No transcorrer da realização da inspeção a autoridade judiciária pode descrever a existência de vestígios da infração penal, bem como as alterações no local ou na coisa inspecionada, quando for possível perceber que os vestígios foram removidos ou alterados pela pessoa que detém a posse ou por terceiros.

\subsubsection{A BUSCA NO DIREITO ITALIANO}

As buscas (perquisizioni) estão disciplinadas nos artigos 247 a 252 do Código de Processo Penal italiano e têm por escopo assegurar a apreensão de coisa determinada que esteja relacionada com o objeto do processo ou realizar a prisão de determinada pessoa.

$\mathrm{Na}$ fase das investigações preliminares a busca é ordenada pelo representante do ministério público, que pode executar a medida ou delegar a um agente da polícia judiciária, na forma do artigo 365 do Códice di Procedura Penale italiano. Como a medida abrange a busca de coisas e pessoas, está previsto que, nos casos de flagrante ou de fuga, a polícia judiciária pode realizar as buscas, sem ordem do ministério público, que serão ou não convalidadas por aquele órgão, na forma do artigo 352 do mesmo diploma legal.

Segundo Mario Chiavario, tanto nas buscas determinadas pelo juiz quanto nas buscas determinadas pelo ministério público, a realização da medida é delegada para a polícia judiciária ${ }^{264}$. Apesar da previsão dos artigos 352 e 365 do Códice di Procedura Penale italiano, as buscas, em regra, devem ser determinadas pela autoridade judiciária em decisão fundamentada, conforme estabelece o artigo 247, respeitados alguns requisitos.

\footnotetext{
${ }^{263}$ Nesse sentido: "Nel corso dell'ispezione l'autorità giudiziaria può inoltre disporre che vengano effettuati rilievi segnaletici, descrittivi, fotografici ed eventuali altre operazioni tecniche (art. 244 c.p.p.)." (SIRACUSANO, Delfino et al. Diritto processuale penale. Milano: Giuffrè, 2006. v. 1. p. 401).

264 Cf. CHIAVARIO, Mario. DELEUZE, B.; DELMAS-MARTY, Mireille. Procedure penali d'Europe: Belgio, Francia, Germania - Inghilterra - Italia. Milano: CEDAM, 2001. p. 320.
} 
São requisitos para o decreto de busca a existência de fundados motivos de que alguém oculta objetos pertinentes ao delito ou o próprio corpo de delito em determinado local ou de que em determinado local possa se executar a prisão do imputado ou foragido. Outro requisito da medida é a entrega obrigatória, para a pessoa que detém a posse do lugar ou da coisa apreendida, da cópia do mandado que determinou a busca, conforme dispõe o artigo 250 do mesmo diploma legal ${ }^{265}$, para que ela possa ser assistida por pessoa de sua confiança ${ }^{266}$.

As buscas de dados informáticos ou telemáticos não estavam disciplinadas no processo penal italiano e eram meios de obtenção de provas atípicos, cuja possibilidade estava sujeita à norma geral de admissibilidade das provas não disciplinadas pela lei, estabelecida no artigo 189.1 do Códice di Procedura Penale italiano ${ }^{267}$. Em março de 2008, a redação do artigo 247 do Códice di Procedura Penale italiano foi alterada, incorporando as buscas de dados informáticos ou telemáticos, com a ressalva de que tal medida deve adotar técnicas diretas para assegurar a conservação dos dados originais e impedir sua alteração.

\begin{abstract}
1-bis. Quando vi è fondato motivo di ritenere che dati, informazioni, programmi informatici o tracce comunque pertinenti al reato si trovino in un sistema informatico o telematico, ancorché protetto da misure di sicurezza, ne è disposta la perquisizione, adottando misure tecniche dirette ad assicurare la conservazione dei dati originali e ad impedirne l'alterazione. ${ }^{268}$
\end{abstract}

Apesar de a referida norma não ter disciplinado detalhadamente o procedimento de busca e de apreensão de dados, o sistema processual penal italiano trouxe uma inovação ao prever e disciplinar a apreensão eletrônica, como cumprimento aos preceitos da Convenção

265 "1. Nell'atto di iniziare le operazioni, copia del decreto di perquisizione locale è consegnata all'imputato, se presente, e a chi abbia l'attuale disponibilità del luogo, con l'avviso della facoltà di farsi rappresentare o assistere da persona di fiducia, purché questa sia prontamente reperibile e idonea a norma dell'articolo 120.".

${ }^{266}$ Cf. SIRACUSANO, Delfino et al., 2006, p. 402-403.

${ }^{267}$ Sobre o tema da liberdade dos meios de prova, cabe destacar a ressalva desenvolvida por Ennio Amodio: "Al giudice è consentito assumere prove atipiche, vale a dire non disciplinate dalla legge, con l'obbligo peraltro di accertare preventivamente la loro idoneità ai fini dell'accertamento e la loro attitudine a offrire un contributo conoscitivo tale da non pregiudicare la libertà morale della persona (art. 189 c.p.p.)." (AMODIO, Ennio. Libero convincimento e tassatività dei mezzi di prova: un approccio comparativo. Rivista Italiana di Diritto e Procedura Penale, Milano, v. 42, n. 1, p. 3-9, gen./mar. 1999. p. 6).

${ }^{268}$ ITÁLIA. Legge 18 marzo 2008, n. 48. Ratifica ed esecuzione della Convenzione del Consiglio d'Europa sulla criminalità informatica, fatta a Budapest il 23 novembre 2001, e norme di adeguamento dell'ordinamento interno. Disponível em: $<$ http://legxv.camera.it/parlam/leggi/080481.htm>. Acesso em: 29 ago. 2012. 
sobre o Cibercrime do Conselho da Europa, realizada na cidade de Budapeste em 23 de novembro de $2001^{269}$.

\subsubsection{A APREENSÃo NO DIREITO ITALIANO}

A apreensão no sistema processual penal italiano, sequestro probatório, está disciplinada nos artigos 252 a 265 do Código de Processo Penal desse país, logo após a disciplina das buscas (perquisizioni), uma vez que nesta são delimitados os objetos passíveis de apreensão (sequestro probatorio).

A apreensão deve ser determinada por decisão motivada, autorizando a apreensão tanto do corpo de delito quanto dos objetos pertinentes ao delito necessários à solução da causa. Entretanto, cumpre observar que o Códice di Procedura Penale italiano define, em seu artigo 253, corpo de delito como "[...] le cose sulle quali o mediante le quali il reato è stato commesso nonché le cose che ne costituiscono il prodotto, il profitto o il prezzo." ${ }^{270}$.

Tal definição é muito mais abrangente do que a utilizada no sistema processual penal brasileiro; a apreensão, naquele sistema, equipara os vestígios materiais do crime ao produto do crime, o que traz reflexos diretos ao entendimento a respeito dos objetos passíveis de apreensão ${ }^{271}$.

Para o decreto de apreensão, devem ser observados, dentre outros, os mesmos requisitos disciplinados para a busca. Entretanto, Paolo Tonini destaca como o mais importante o requisito da efetiva necessidade para a avaliação dos fatos ${ }^{272}$.

269 EUROPA. Convention on Cybercrime. Budapeste, 23.XI.2001. Disponível em: $<$ http://conventions.coe.int/ Treaty/en/Treaties/Html/185.htm>. Acesso em: 29 ago. 2012.

${ }^{270}$ ITALIA, 1988.

271 A jurisprudência italiana já decidiu que também no caso das apreensões de corpo de delito é necessário o preenchimento dos requisitos previstos no Códice di Procedura Penale italiano: "Cass., sez. Uni., 28 gennaio - 13 febbraio 2004 n.2, Ferrazzi, in Cass. Pen., 2004, 1913: 'anche per le cose Che costituiscono corpo di reato il decreto di sequestro a fini di prova deve essere sorretto, a pena di nullità, da idonea motivazione in ordine al presupposto della finalità perseguita, in concreto, per l'accertamento dei fati'." (TONINI, Paolo, 2007, p. 381).

272 "E, soprettutto, che la cosa sia 'necessaria' per l'accertamento dei fatti." (TONINI, Paolo, 2007, p. 325). 
Outra característica importante diz respeito a autoridade que deve determinar a execução da medida, visto que na fase de debates a apreensão deve ser determinada pela autoridade judicial, enquanto na fase das investigações preliminares, pelo ministério público $^{273}$, conforme autoriza o artigo 365 do Códice di Procedura Penale italiano.

O artigo 254 do Códice di Procedura Penale italiano, alterado pela Lei $n^{\circ}$ 48, de 18 de março de 2008, estabelece como modalidades da medida de apreensão a apreensão de correspondência comum e eletrônica e a apreensão de dados dos serviços de informática, telemática e telefonia.

O artigo seguinte do mesmo diploma legal disciplina a apreensão em instituições financeiras, prevista explicitamente ${ }^{274}$, e estabelece a possibilidade de apreensão de documentos, títulos, valores, conteúdos de cofres, sempre que se tenham fundados motivos que sejam relevantes para a apuração do delito, independentemente de pertencerem ou não ao acusado. Segundo Paolo Tonini, quando a instituição financeira opõe uma recusa ao decreto de apreensão, o juiz ou o ministério público, na fase das investigações preliminares, podem proceder a uma inspeção pessoalmente na instituição financeira ${ }^{275}$.

Contra a decisão que determinou a apreensão cabe recurso, na forma dos artigos 257 e 324 do Códice di Procedura Penale italiano, contudo o recurso não suspende a execução da medida.

Uma disposição interessante do sistema processual penal italiano, que demonstra o respeito ao sujeito que detinha legitimamente os documentos apreendidos e que entre nós não existe, está prevista no artigo 258, que estabelece a entrega gratuita de cópias autenticadas dos documentos apreendidos ao legítimo possuidor ${ }^{276}$.

${ }^{273}$ Da mesma forma como ocorre nas medidas de busca, quando o ministério público não puder intervir tempestivamente, facultará à polícia judiciária a proceder à apreensão na forma do artigo 354.2 do Códice di Procedura Penale italiano.

274 “Art. 255. Sequestro presso banche. 1. L'autorità giudiziaria può procedere al sequestro presso banche di documenti, titoli, valori, somme depositate in conto corrente e di ogni altra cosa, anche se contenuti in cassette di sicurezza, quando abbia fondato motivo di ritenere che siano pertinenti al reato, quantunque non appartengano all'imputato o non siano iscritti al suo nome.".

275 Cf. TONINI, Paolo, 2007, p. 327.

276 "258.1. L'autorità giudiziaria può fare estrarre copia degli atti e dei documenti sequestrati, restituendo gli originali, e, quando il sequestro di questi è mantenuto, può autorizzare la cancelleria o la segreteria a rilasciare gratuitamente copia autentica a coloro che li detenevano legittimamente." (grifo nosso). 
Por fim, cumpre observar que a restituição das coisas apreendidas pode ocorrer antes da sentença ${ }^{277}$, mas pode o tribunal exigir caução idônea para cada uma das restituições. De outro lado, as apreensões só podem se estender até o final do processo e, quando do seu término, devem ser restituídas ou podem ser convertidas em sequestro preventivo, sequestro conservativo ou confisco, quando preenchidos os requisitos específicos de cada uma dessas medidas cautelares reais previstas ${ }^{278}$.

Finda essa breve análise do direito comparado, passaremos a analisar a disciplina da busca e da apreensão no Código de Processo Penal brasileiro, abordando a disciplina geral das buscas e das apreensões e, em seguida, especificamente no que concerne ao procedimento dos crimes contra a propriedade imaterial, identificando a natureza jurídica da nova medida de apreensão introduzida pela Lei n ${ }^{0} 10.695 / 2003$.

\footnotetext{
${ }^{277}$ Sobre o tema, é importante ressaltar que a restituição de coisas apreendidas nos casos de criminalidade organizada na Itália obedecem às diretrizes da Convenção de Palermo, que sugere a adoção da inversão do ônus da prova para essa restituição no curso do processo, ou seja, a demonstração, pelo imputado, da origem lícita dos bens apreendidos.

${ }^{278}$ Cf. SIRACUSANO, Delfino et al., 2006, p. 405-406.
} 


\section{CAPÍTULO IV - A APREENSÃO NO PROCEDIMENTO COMUM E NO PROCEDIMENTO DOS CRIMES CONTRA A PROPRIEDADE IMATERIAL}

\subsection{A BUSCA E A APREENSÃo COMO INSTITUTOS AUTÔNOMOS}

A dificuldade da doutrina em identificar a natureza jurídica da busca decorre de dois aspectos: primeiro, a unidade legislativa da busca e da apreensão; segundo, o dissenso classificatório:

\footnotetext{
[...] ora como meio de prova, ora instrumento de sua obtenção; ou, ainda, coação processual penal lícita. Veja-se que, quanto ao primeiro aspecto, desponta, novamente, indispensável a separação da busca da apreensão, posto não possuírem mesma natureza jurídica, não obstante os pontos comuns. ${ }^{279}$
}

Mesmo nos dicionários jurídicos não existe definição da busca como um instituto autônomo, conceituando-a sempre em conjunto com a apreensão:

BUSCA E APREENSÃO. É a diligência policial ou judicial que tem por fim procurar coisa ou pessoa que se deseja encontrar, para trazê-la à presença da autoridade que a determinou. A busca e apreensão se faz para ir procurar e trazer a coisa litigiosa, a pedido de uma das partes, para procurar e apreender a coisa roubada ou sonegada. ${ }^{280}$

Eduardo Espínola Filho, ao tratar da matéria, definiu a busca, embasado nos trabalhos de Mayer e Manzini, como pesquisas materiais realizáveis coercitivamente, autorizadas como exceção às garantias normais da liberdade individual e destinadas a assegurar, ao processo, coisas que possam servir à prova, ou a prender o acusado (ou outra pessoa indiciada de crime ou evadida) ou apreender pessoas que tenham sofrido a ação criminosa alheia ${ }^{281}$.

Edgard Magalhães Noronha, por sua vez, citando a definição de Mayer traduzida por Espínola Filho, definiu as buscas e apreensões, como “[...] meio coercitivo pelo qual é, por lei, utilizada a força do Estado para apossar-se de elementos de prova, de objetos a confiscar, ou da pessoa do culpado, ou para investigar os vestígios de um crime."282. Tal

\footnotetext{
279 PITOMBO, Cleunice A. Valentim Bastos, 2005, p. 109.

280 SILVA, De Plácido, 2004, p. 233.

281 ESPÍNOLA FILHO, Eduardo. Código de Processo Penal Brasileiro anotado. Rio de Janeiro: Livraria Freitas Bastos, 1942. p. 153-154.

282 NORONHA, Edgard Magalhães. Curso de direito processual penal. 8. ed. São Paulo: Saraiva, 1976. p. 88 .
} 
definição mostra, de forma clara, a unidade conceitual que era dispensada aos institutos pela doutrina nacional.

\begin{abstract}
Normalmente, à busca sucede a apreensão do que se encontrou. Provavelmente, por haver essa normal relação de meio a fim, o CPP tratou dos dois institutos como se fossem inseparáveis e indissociáveis. Todavia, embora não seja comum, é possível separar a busca da apreensão, podendo uma ocorrer sem a outra. ${ }^{283}$
\end{abstract}

Por esse motivo, mostra-se imprescindível, para o presente trabalho, estabelecer os conceitos de busca e de apreensão, identificando as diferenças e a natureza jurídica de cada um deles para, a seguir, analisarmos a disciplina da apreensão no processo penal brasileiro.

\title{
4.1.1 O CONCEITO DE BUSCA
}

O termo "busca", do verbo "buscar", significa procura, investigação, pesquisa, exame, ato de buscar ${ }^{284}$, que por sua vez é procurar com empenho ou intenção de descobrir; procurar com interesse de descobrir; percorrer algum lugar para procurar pessoa ou objeto.

\begin{abstract}
A compreensão etimológica de busca não difere, em substância, do significado jurídico. Expressando ambos o ato de procurar, varejar, rastrear, tentar descobrir. No sentido jurídico, porém, se tem como finalidade o encontro de vestígios, coisas ou pessoas, relacionadas com um fato investigado. ${ }^{285}$
\end{abstract}

Podemos, aqui, aproveitar o conceito elaborado por Espínola Filho, embasado principalmente no trabalho de Manzini, porque não confunde a medida de busca com a medida de apreensão - talvez, porque, como vimos, no sistema processual penal italiano as buscas (perquisizione) estão disciplinadas em título diverso do das apreensões (sequestro probatorio).

Assim, as buscas são pesquisas materiais realizáveis coercitivamente, autorizadas como exceção às garantias individuais e destinadas a colher elementos relacionados com o fato investigado.

\footnotetext{
${ }^{283}$ BADARÓ, Gustavo Henrique Righi Ivahy. Direito processual penal. Rio de Janeiro: Elsevier, 2008. tomo 1. p. 271

${ }^{284}$ Cf. BUSCA. In: HOUAISS, Antônio; VILLAR, Mauro de Salles; FRANCO, Francisco Manoel de Mello. Houaiss Dicionário da Língua Portuguesa. Rio de Janeiro: Objetiva, 2001. p. 67.

285 PITOMBO, Cleunice A. Valentim Bastos, 2005, p. 107.
} 
O conceito elaborado por Cleunice Valentim Bastos Pitombo é, sem dúvida, o mais completo, ao definir que a busca

[...] é ato do procedimento persecutivo penal, restritivo de direito individual (inviolabilidade da intimidade, vida privada, domicílio e da integridade física ou moral), consistente em procura, que pode ostentar-se na revista ou no varejamento, conforme a hipótese: de pessoa (vítima de crime, suspeito, indiciado, acusado, condenado, testemunha e perito), semoventes, coisas (objetos, papéis e documentos), bem como de vestígios (rastros, sinais e pistas) da infração. ${ }^{286}$

Com base na adequada conceituação da busca — ato do procedimento penal restritivo de direitos individuais que consiste em revista (busca pessoal) ou varejamento (busca domiciliar) e tem como fim encontrar e apreender ou prender pessoas, semoventes, coisas ou vestígios da infração - como instituto autônomo da apreensão, passaremos, então, ao conceito de apreensão.

\subsubsection{O CONCEITO DE APREENSÃO}

Ao contrário do que ocorre no caso da busca, podemos encontrar definição isolada de apreensão nos dicionários jurídicos, que conceituam o vocábulo como derivado do termo latino "apprehendere", que significa tomar, agarrar, apoderar-se, a ação e o efeito de se tirar de alguém, ou tomar de outrem, coisa que se encontrava em seu poder ou de apoderar-se de coisa abandonada. ${ }^{287}$

No direito processual penal, a apreensão também importa na inversão de posse, coercitiva ou voluntária, da coisa apreendida, que ficará indisponível enquanto necessária ao inquérito policial ou ao processo penal.

\footnotetext{
No direito processual penal brasileiro, pode-se conceituar a apreensão como ato processual penal, subjetivamente complexo, de apossamento, remoção e guarda de coisas - objetos, papéis ou documentos - de semoventes e de pessoas, "do poder de quem as retém ou detém"; tornando-as indisponíveis, ou as colocando sob custódia, enquanto importarem à instrução criminal ou ao processo. A apreensão pode ser coercitiva - originada em busca -, ou espontânea - livre apresentação, ou exibição. Implica, sempre, constrição. ${ }^{288}$
}

${ }^{286}$ PITOMBO, Cleunice A. Valentim Bastos, 2005, p. 109.

${ }^{287}$ SILVA, De Plácido, 2004, p. 122.

${ }^{288}$ PITOMBO, Cleunice A. Valentim Bastos, 2005, p. 230. Destacamos apenas que a apreensão coercitiva, principalmente no procedimento dos crimes contra a propriedade imaterial, pode ocorrer sem a realização da busca, uma vez que os objetos contrafeitos podem ser encontrados e apreendidos em locais abertos ao 
A apreensão é, portanto, um ato processual penal complexo que pode ser coercitivo (decorrente da busca ou da localização em locais públicos ou abertos ao público) ou voluntário (apresentação ou exibição da coisa com a respectiva entrega) e que implica sempre a constrição do direito de disposição de coisas, semoventes e pessoas, de quem as detém ou retém; por meio de apossamento, remoção e guarda, torna-as indisponíveis ou coloca-as sob custódia enquanto forem necessárias ao inquérito policial ou ao processo penal.

Antes de analisarmos a natureza jurídica da busca e da apreensão, é necessário fazermos uma breve nota sobre a terminologia processual no que diz respeito ao emprego do termo "prova", distinguindo as expressões "fonte de prova", "meio de prova" e "meio de obtenção de prova".

\subsubsection{FONTE DE PROVA, MEIO dE PROVA E MEIO DE OBTENÇÃo DE PROVA}

No direito processual as expressões "fonte de prova", "meio de prova" e "meio de obtenção de prova" são utilizadas para distinguir a natureza jurídica dos institutos pela função que eles exercem no direito processual.

As fontes de prova dividem-se em fontes pessoais e reais, sendo as primeiras aquelas das quais se obtêm as declarações ou depoimentos - e, portanto, são os acusados, as vítimas, as testemunhas, os informantes e os peritos. As pessoas também podem ser objeto de prova pericial, em especial os acusados e as vítimas, quando nelas se puder encontrar vestígios da infração penal. As fontes reais, por sua vez, são as coisas e os semoventes das quais podem ser extraídos outros elementos de prova - em regra, pelo meio de prova documental ou pericial ${ }^{289}$.

Os meios de prova referem-se à atividade endoprocessual que se desenvolve perante o juiz, com o conhecimento e a participação das partes, com o objetivo de

público, tais como lojas e "camelódromos", e na própria via pública, em tabuleiros de ambulantes. Tais medidas de apreensão prescindem de ordem de busca, porque são realizadas em locais públicos ou abertos ao público.

289 Cf. GOMES FILHO, Antonio Magalhães, 2005, p. 309. 
introduzir e fixar os elementos de prova no processo $^{290}$. Dessa forma, podemos identificar os meios de prova como as atividades das quais se serve o juiz - com a participação das partes e respeitando o tipo processual previsto - para obter, de forma idônea e criteriosa, os elementos de prova.

$\mathrm{Na}$ maioria dos ordenamentos jurídicos contemporâneos estão previstos ao menos três meios de prova típicos, sendo eles a prova documental, a prova pericial e a prova testemunhal. Existem ordenamentos que estabelecem outros meios de prova típicos, e, da mesma forma, existem ordenamentos jurídicos que permitem meios de prova atípicos ${ }^{291}$.

Por fim, existem atividades que não são destinadas a trazer ao processo elementos de prova, mas a obter fontes de prova, por meio das quais se realizarão outras atividades (meios de prova) para inserir, no processo, elementos probatórios úteis à decisão. Essas atividades, em geral extraprocessuais, de investigação e obtenção de fontes de prova são os chamados meios de obtenção de fontes de prova ou meios de investigação da prova.

Dentre elas, podemos destacar as apreensões — que abordaremos a seguir —, " [ ...] as interceptações telefônicas, disciplinadas pela Lei 9.296/96, a infiltração de agentes (Lei 9.034/95) e a captação e interceptação ambiental de sinais eletromagnéticos, óticos e acústicos (Lei 10.217/2001). ${ }^{292}$.

O professor Antonio Scarance Fernandes aponta que algumas medidas, como a busca, a apreensão e a interceptação telefônica, permitem tanto a obtenção de fontes de prova como a obtenção de elementos de prova, classificando-as como meios de obtenção de prova.

\footnotetext{
Comum, atualmente, considerar que tais atividades constituem meios de investigação ou de obtenção de prova e, assim, seriam atividades cautelares, destinadas a descobrir e a resguardar a fonte de prova. Ocorre que os elementos obtidos por alguns desses meios acabam sendo considerados elementos de prova, como sucede com os bens apreendidos durante uma busca domiciliar, não tendo a natureza de uma providência simplesmente cautelar. Preferível, assim, considerar que essas atividades configuram genericamente meios de obtenção de

${ }^{290}$ Cf. GOMES FILHO, Antonio Magalhães, 2005, p. 309.

${ }^{291}$ Cf. FERNANDES, Antonio Scarance. Tipicidade e sucedâneos de prova. In: FERNANDES, Antonio Scarance; ALMEIDA, José Raul Gavião de; MORAES, Maurício Zanoide de (Coords.). Provas no processo penal: estudo comparado. São Paulo: Saraiva, 2011. p. 13-45. p. 28-29.

292 GOMES FILHO, Antonio Magalhães, 2005, p. 309.
} 
prova, distinguindo-se entre as que se prestam à colheita de elementos informativos e as que, desde logo, servem para coletar elementos de prova. ${ }^{293}$

Concordamos com a afirmação de que as medidas permitem a colheita tanto de elementos informativos quanto de elementos de prova. Contudo, apesar de adotarmos a corrente que classifica essas medidas como meios de obtenção de prova, entendemos que tanto na busca e na apreensão como na interceptação telefônica o resultado obtido deve ser introduzido no processo utilizando-se de um meio de prova típico - em regra, a prova documental ou a prova pericial (mesmo que a perícia consista na simples constatação dos bens apreendidos).

Isso permite que se assegurem a paridade de armas e o contraditório, uma vez que a prova documental pode ser questionada pelo mecanismo do incidente de falsidade documental e a prova pericial, por sua vez, pode ser questionada pelos quesitos e pelos esclarecimentos do perito em audiência.

\subsubsection{A NATUREZA JURÍDiCA DA BUSCA}

A busca já teve sua natureza jurídica definida como medida cautelar, meio de prova e meio de obtenção de prova, uma vez que era entendida como instituto indissociável da apreensão e, portanto, deveria englobar a natureza jurídica desta. Autores como Paulo Lúcio Nogueira chegaram a definir a natureza jurídica da busca como instituto autônomo, disciplinando a busca como "[...] medida acautelatória, liminar, destinada a evitar o perecimento das coisas [... $]^{, 294}$, sem dispensar qualquer tratamento ou definição para a apreensão.

Entretanto, a busca é instituto autônomo, circunscrito ao ato de revista ou varejamento, com o escopo de encontrar pessoas, semoventes, coisas ou vestígios relacionados com o fato investigado.

293 FERNANDES, Antonio Scarance, 2011, p. 25.

294 NOGUEIRA, Paulo Lúcio. Curso completo de processo penal. 2. ed. São Paulo: Saraiva, 1986. p. 113. 
As buscas dividem-se em domiciliares e pessoais, sendo as primeiras disciplinadas no parágrafo $1^{\circ}$ do artigo 240 do Código de Processo Penal. O referido dispositivo legal autoriza a determinação de uma medida de busca quando existirem fundadas razões para:
a) prender criminosos;
b) apreender coisas achadas ou obtidas por meios criminosos;
c) apreender instrumentos de falsificação ou de contrafação e objetos falsificados ou contrafeitos;
d) apreender armas e munições, instrumentos utilizados na prática de crime ou destinados a fim delituoso;
e) descobrir objetos necessários à prova de infração ou à defesa do réu;
f) apreender cartas, abertas ou não, destinadas ao acusado ou em seu poder, quando haja suspeita de que o conhecimento do seu conteúdo possa ser útil à elucidação do fato;
g) apreender pessoas vítimas de crimes;
h) colher qualquer elemento de convicção.

Exceto nos casos de apreensão de vítimas de crime, em que a vítima será custodiada e imediatamente liberada pela autoridade responsável pela medida, e nos casos de prisão (em flagrante, preventiva ou temporária), todas as demais hipóteses previstas nesse dispositivo relacionam-se com o objeto do processo.

As buscas pessoais, por sua vez, estão disciplinadas no parágrafo $2^{\circ}$ do artigo 240 do Código de Processo Penal, o que permite que a busca pessoal seja determinada quando houver fundada suspeita de que alguém oculta consigo arma proibida ou quaisquer dos objetos previstos nas hipóteses de busca domiciliar.

Segundo Gustavo Henrique Righi Ivahy Badaró, a

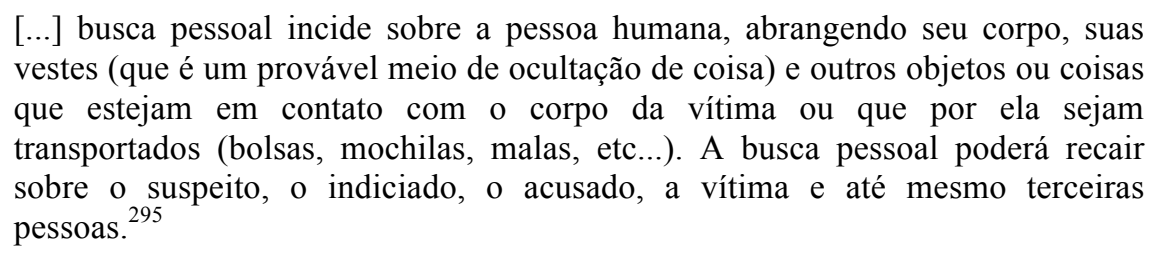

Dessa forma, as buscas têm por finalidade encontrar pessoas (autor ou vítima de crime), coisas e semoventes relacionados ao crime, entretanto não é a medida de busca que trará tais elementos ao processo como meio de prova (atividade endoprocessual desenvolvida perante o juiz, com a participação das partes, com o objetivo de introduzir e fixar os elementos de prova no processo), dado que a medida se restringe à procura.

295 BADARÓ, Gustavo Henrique Righi Ivahy, 2008, p. 274. 
A busca, no processo penal brasileiro, não constitui prova, nem meio para sua obtenção (a busca por exemplo, para a prisão, custódia e para a intimação); consiste, na verdade, em medida instrumental, com restrição a certos direitos fundamentais, no escopo de achar, encontrar pessoa, semoventes, coisas ou vestígios, que de modo direto ou indireto, se relacionem com fato, pretensamente, ilícito e típico, investigado ou perquirido. ${ }^{296}$

Por esse motivo, podemos definir a natureza jurídica da busca como medida instrumental restritiva de direitos fundamentais que se consubstancia em meio de obtenção de prova, exceto nos casos de prisão. As apreensões de pessoas - em especial, das vítimas — não deixam de ser casos de meios de obtenção de provas, visto que nelas podem ser encontrados, pela realização de prova pericial, os vestígios de eventuais agressões infligidas no transcorrer da prática criminosa.

Dessa forma, podemos concluir que a medida de busca permite, mediante ordem judicial escrita e fundamentada, que se realize a busca pessoal ou domiciliar, com o escopo de revistar, varejar e encontrar coisas, semoventes e pessoas relacionados nas alíneas do artigo 240, $\S \S 1^{\circ}$ e $2^{\circ}$, do Código de Processo Penal.

Se o resultado da busca for negativo, nenhum elemento será trazido ao processo; se o resultado for positivo, outra medida deve ser efetivada, para apoderar-se de tais objetos, invertendo, de forma coercitiva, a posse dos itens encontrados. Essa nova medida a ser utilizada é a apreensão, cujo conceito e cuja natureza jurídica veremos a seguir.

Em ambos os casos, com ou sem apreensão, a medida de busca não deixa de ser um meio de obtenção de prova, uma vez que qualquer meio de obtenção de prova pode ou não encontrar elementos úteis ao processo e que os resultados negativos têm sua importância, pois podem ser úteis para a confirmação das teses defensivas.

296 PITOMBO, Cleunice A. Valentim Bastos, 2005, p. 116-117. Por causa das hipóteses previstas para os casos de prisão e custódia e para a intimação, a autora deixa de classificar a natureza jurídica da busca como meio de obtenção de prova. No entanto, nos parece mais adequado classificá-la de meio de obtenção de provas e excepcionar as hipóteses de prisão. 


\subsubsection{A NATUREZA JURÍDICA DA APREENSÃo}

O artigo 240 do Código de Processo Penal brasileiro estabelece nas alíneas "b" a "f" as coisas que podem ser apreendidas, sendo elas: coisas achadas ou obtidas por meios criminosos; instrumentos de falsificação ou contrafação; armas, munições, instrumentos utilizados na prática de crimes ou destinados a fins delituosos; objetos necessários à prova de infração ou à defesa do réu; cartas destinadas ao acusado ou em seu poder, quando houver suspeita de que o conhecimento do seu conteúdo pode ser útil à elucidação do fato.

Nesse sentido, as apreensões mostram-se previstas em nosso ordenamento processual penal como medidas destinadas ao apossamento, à remoção e à guarda de coisas, com o fim de auxiliar a instrução processual.

Logo, só podem ser apreendidas as coisas que efetivamente importem para a instrução, tais como os instrumentos utilizados para a prática criminosa, os bens obtidos por meio da prática criminosa ou resultantes dela e os objetos e as correspondências necessários à prova da infração ou à defesa do acusado.

$\mathrm{Na}$ doutrina nacional, não há consenso sobre a natureza jurídica da apreensão, talvez, como dissemos, pelo tratamento unitário dispensado à disciplina da busca e da apreensão, talvez pelas dificuldades decorrentes da terminologia relacionada à prova no processo penal brasileiro.

Espínola Filho classifica de fonte de prova a natureza jurídica da apreensão, conceituando-a como meio coercitivo lícito - como exceção às garantias normais da liberdade individual — destinado a assegurar ao processo coisas que possam servir de prova. $^{297}$

Magalhães Noronha, utilizando a definição de Mayer traduzida por Espínola Filho, classificou de medida acautelatória a natureza jurídica da busca e apreensão. Paulo Lúcio Nogueira definiu a busca como medida acautelatória, e não dispensou qualquer esforço para identificar a natureza jurídica da apreensão ${ }^{298}$.

\footnotetext{
297 ESPÍNOLA FILHO, Eduardo, 1942, p. 153.

298 NOGUEIRA, Paulo Lúcio, 1986, p. 113.
} 
Autores contemporâneos, como Julio Fabbrini Mirabete, repetiram o conceito sem qualquer análise crítica, classificando a busca e a apreensão como medidas acautelatórias, liminares, destinadas a evitar o perecimento de coisas e pessoas ${ }^{299}$. Com a mesma imprecisão, Adalberto José Q. T. de Camargo Aranha repetiu o conceito unitário de busca e apreensão, definindo-o como "[...] medida cautelar asseguradora de uma prova que se deseja perpetuar e que pode ser produzida antes ou durante o inquérito policial, como no decorrer da ação penal e até na própria execução. ${ }^{300}$.

Dentre outros, Eduardo Pimenta e Rui Caldas Pimenta também dispensaram tratamento unitário a ambas as medidas, definindo a natureza jurídica destas sem a menor precisão técnica: “O legislador penal interpretou a busca e apreensão como uma medida preparatória, e a incluiu no Título VII (Da prova), admitindo-se um meio de execução de medida preventiva." 301.

Dos que dispensaram tratamento específico para a medida de apreensão, podemos destacar, em um primeiro grupo, André Estefam, que definiu a apreensão como consequência da busca $^{302}$, Guilherme de Souza Nucci, que, apesar de citar o trabalho de Cleunice Pitombo, definiu a apreensão como medida assecuratória que, "[...] eventualmente, tem a finalidade de atuar como meio de prova [...]"303, e Aury Lopes Jr., que, por sua vez, definiu a apreensão como medida cautelar probatória, pois se destina à garantia da prova e ainda, dependendo do caso, à própria restituição do bem a seu legítimo dono $^{304}$.

Em um segundo grupo, podemos destacar o trabalho de Cleunice Pitombo, que classifica a natureza jurídica da apreensão de acordo com a função, podendo ser medida

\footnotetext{
299 MIRABETE, Julio Fabbrini. Processo penal. 17. ed. São Paulo: Atlas, 2005. p. 345.

300 ARANHA, Adalberto José Q. T. de Camargo. Da prova no processo penal. 7. ed. São Paulo: Saraiva, 2006. p. 270.

301 PIMENTA, Eduardo; PIMENTA, Rui Caldas. Dos crimes contra a propriedade intelectual. 2. ed. São Paulo: Revista dos Tribunais, 2005. p. 292.

302 “A apreensão, por sua vez, é a medida que se sucede à busca. Trata-se de sua consequência e ocorrerá sempre que a busca for concluída com êxito." (ESTEFAM, André. Provas e procedimentos no processo penal. São Paulo: Damásio de Jesus, 2008. p. 66).

303 NUCCI, Guilherme de Souza. Provas no processo penal. 2. ed. São Paulo: Revista dos Tribunais, 2011. p. 207.

304 LOPES JR., Aury. Direito processual penal e sua conformidade constitucional. 5. ed. Rio de Janeiro: Lumen Juris, 2010. v. 1. p. 691.
} 
cautelar, meio de prova ou meio de obtenção de prova ${ }^{305}$, e Antonio Scarance Fernandes, que, como já dissemos, classifica a apreensão como meio de obtenção de provas porque serve tanto para descobrir e resguardar a fonte de prova como para obter elementos de $\operatorname{prova}^{306}$.

Gustavo Badaró definiu a apreensão como medida assecuratória — vez que toma algo de alguém ou de algum lugar — que tem a finalidade de produzir prova ou preservar direitos, caracterizando-a, portanto, como meio de obtenção da prova.

\begin{abstract}
A busca e eventual apreensão da coisa ou da pessoa, em si, nada provam. Mas, por meio da busca e da apreensão se conservam os elementos de provas que forma apreendidos (p. ex.: diários, cartas, livros, contábeis). Posteriormente, dependendo da fonte de prova (pessoa ou coisa) que foi obtida, deverá ser produzido o meio de prova correspondente. Assim, por exemplo, as cartas ou diários serão juntados ao processo como documentos (estes sim, serão os meios de prova), no caso de um livro contábil poderá ser submetido à perícia para, por exemplo, verificar eventual crime de sonegação fiscal. Mesmo no caso de busca pessoal, a pessoa encontrada e submetida à custódia será apenas uma fonte de prova. Se, por exemplo, se tratava de vítima de crime de extorsão mediante seqüestro ou de redução à condição análoga à de escravo, poderá comparecer a juízo e prestar declarações. O meio de prova, contudo, não será a busca e a apreensão da pessoa, mas as "declarações do ofendido". 307
\end{abstract}

Por outro lado, apesar de concordarmos com a afirmação de que a apreensão, em regra, é meio de obtenção de prova, temos de destacar que a medida de apreensão prevista no artigo 530-B do Código de Processo Penal não pode ser classificada apenas como tal, visto que se presta tanto à apreensão do corpo de delito quanto à apreensão de todos os bens ilicitamente produzidos ou reproduzidos. Logo, não há como mascarar a natureza jurídica da medida, que, além de servir como meio de obtenção de prova, é satisfativa, pois permite a retirada antecipada de todos os bens incriminados antes de qualquer análise pericial.

Observadas as dificuldades doutrinárias em estabelecer um conceito adequado e autônomo para o instituto da apreensão, bem como as dificuldades em classificar sua natureza jurídica, passaremos para uma breve análise da apreensão no procedimento comum e nos procedimentos dos crimes contra a propriedade imaterial, previstos no Código de Processo Penal, destacando as diferenças entre a medida de apreensão comum e a apreensão prevista no artigo 530-B desse diploma legal.

${ }^{305}$ PITOMBO, Cleunice A. Valentim Bastos, 2005, p. 239.

${ }^{306}$ FERNANDES, Antonio Scarance, 2011, p. 25.

307 BADARÓ, Gustavo Henrique Righi Ivahy, 2008, p. 270-271. 


\subsection{A APREENSÃO NO PROCEDIMENTO COMUM}

Apesar de estar disciplinada em conjunto com as buscas no Código de Processo Penal, as apreensões podem se efetivar como consequência das buscas ou de forma autônoma, pela exibição voluntária ou pelo encontro casual de pessoa, semovente ou coisa que deve ser apreendida.

Na primeira hipótese, a apreensão pode ocorrer tanto na fase pré-processual, independentemente da instauração ou não de inquérito policial, como na fase processual, sendo ela preventiva ou incidental. Essa modalidade de apreensão, decorrente da busca profícua, deve respeitar os mesmos limites constitucionais e processuais da busca, uma vez que nem a apreensão ilegal decorrente de busca legal, nem a apreensão legal decorrente de busca ilegal possui qualquer valor para a instrução ${ }^{308}$.

Logo, só podem ser apreendidos os objetos descritos nas alíneas "b" a "f" do parágrafo $1^{\circ}$ do artigo 240 do Código de Processo Penal e as pessoas vítimas de crimes, desde que seja necessário retirá-las do poder de quem as detém ou retém e que a apreensão se mostre imprescindível para a instrução criminal.

A ordem de apreensão decorrente de busca pode ser determinada de ofício ou mediante requerimento do Ministério Público, da autoridade policial, do ofendido ou do presidente de comissão parlamentar de inquérito. Nada impede que o próprio indiciado ou acusado também requeira a apreensão de coisas em poder de terceiros, na forma do artigo 14 do Código de Processo Penal. ${ }^{309}$

\footnotetext{
${ }^{308}$ Nesse sentido: "Desponta inadmissível pretender-se utilizar, em processo penal, qualquer elemento probatório, originário em ato viciado. Vale afirmar: na busca ilegal a apreensão que lhe sucede também é ilegal; busca legal com apreensão ilegal é imprestável para a persecução penal. [...] Assim, eventual ilegalidade ocorrente na busca contagia, por completo, o apossamento dela originário. Nenhum valor, portanto, há de se lhe atribuir no devido processo penal. Inexiste lógica em almejar um processo justo, técnico e ético abandonando as garantias aludidas, nomeadamente o due processs of law: o devido processo e procedimento penal [art. $5^{\circ}$, inc. LIV, da Constituição da República]." (PITOMBO, Cleunice A. Valentim Bastos, 2005, p. 264-265).

${ }^{309}$ PITOMBO, Cleunice A. Valentim Bastos, 2005, p. 271.
} 
Apesar de não existir previsão expressa de que o mandado deve indicar o que deve ser apreendido, não nos parece lícito expedir mandados de busca e de apreensão em branco, permitindo que os executores revistem a pessoa ou varejem o local indiscriminadamente, apreendendo tudo aquilo que entendam que possa hipoteticamente servir aos escopos probatórios da medida.

Portanto, o mandado deve no mínimo indicar quais as espécies de coisas que se pretende procurar com a medida de apreensão, estabelecendo limites aos executores. Caso contrário, não teria sentido a previsão do parágrafo $5^{\circ}$ do artigo 245 do Código de Processo Penal, que determina que, no início da busca domiciliar, o morador seja intimado a apresentar a pessoa ou a coisa que se procura.

Se de um lado não podemos engessar a atividade de investigação impondo uma descrição detalhada dos objetos que devem ser apreendidos, não se pode, de outro lado, permitir a apreensão indiscriminada de coisas que não tenham correlação com a instrução criminal. Ademais, conforme dispõe o artigo 248 do mesmo diploma legal, quando a busca e a apreensão forem realizadas em casa habitada, a busca será feita de modo que não incomode os moradores mais do que o indispensável para o êxito da diligência.

No curso do inquérito policial, ou mesmo antes dele, a diligência será realizada pela autoridade policial, enquanto no curso do processo penal a diligência será realizada por oficial de justiça. Ficam ressalvadas apenas as apreensões realizadas no procedimento dos crimes contra a propriedade imaterial de ação penal de iniciativa privada, que, como veremos, devem ser realizadas diretamente pelos peritos.

Uma vez localizada a pessoa ou a coisa que se procurava ${ }^{310}$, ela será imediatamente apreendida e posta sob custódia da autoridade ou de seus agentes. Os executores, então, lavrarão auto circunstanciado, que deve descrever minuciosamente todas as coisas apreendidas e ser assinado por duas testemunhas presenciais. Caso a diligência tenha sido realizada em local desabitado, servirão como testemunhas presenciais os vizinhos

${ }^{310}$ Se o resultado da busca for negativo, não sendo encontrada a pessoa ou a coisa procurada, os motivos que ensejaram a realização da diligência serão comunicados a quem tiver sofrido a medida, se o requerer, na forma do artigo 247 do Código de Processo Penal. 
intimados a assistir à diligência de busca, na forma do parágrafo $4^{\circ}$ do artigo 245 do Código de Processo Penal.

Quando a autoridade ou seus agentes seguirem pessoa ou coisa para o fim de apreensão $^{311}$, poderão penetrar no território de jurisdição alheia, ainda que de outro Estado, devendo apresentar-se à autoridade local competente e comprovar a legitimidade da atuação, antes ou após a realização da diligência, conforme a urgência e a necessidade da medida.

Na segunda hipótese, quando há exibição espontânea da coisa que deve ser apreendida, também deve ser elaborado um auto circunstanciado, de exibição e apreensão, ressalvando-se apenas que a apreensão só deve ser executada se for imprescindível para a instrução criminal.

\begin{abstract}
A exibição voluntária de coisa móvel, autoriza a apreensão. Não é, porém, toda e qualquer apresentação que se sujeita à analisada constrição. Há que se verificar os seguintes pressupostos: (1) a licitude, ou não, na obtenção da coisa exibida à autoridade policial ou judiciária; (2) a necessidade de retirá-la do poder de quem a retém; e (3) a imprescindibilidade, para a instrução criminal, do apossamento. Faltantes tais elementos, a apreensão se mostra arbitrária e inútil. ${ }^{312}$
\end{abstract}

No referido auto de exibição e apreensão, deve-se descrever de forma minuciosa todas as coisas apreendidas e, nesse caso, como não há ordem judicial fundamentada que justifique a apreensão, entendemos que é necessário que a autoridade manifeste no próprio auto ou em decisão apartada os motivos da apreensão, submetendo-a em seguida à apreciação judicial.

Não sendo caso de apreensão, ou estando presente o legítimo proprietário, em cujo favor a restituição deva ser realizada, nada impede que a própria autoridade que recebeu a coisa exibida faça a apreensão e em momento imediatamente subsequente proceda à entrega da coisa para o legítimo titular ou para fiel depositário.

\footnotetext{
311 Dispõe o parágrafo $1^{\circ}$ do artigo 250 do Código de Processo Penal que se entende que a autoridade vai em seguimento da pessoa ou coisa quando: "a) tendo conhecimento direto de sua remoção ou transporte, a seguirem sem interrupção, embora depois a percam de vista; b) ainda que não a tenham avistado, mas sabendo, por informações fidedignas ou circunstâncias indiciárias, que está sendo removida ou transportada em determinada direção, forem ao seu encalço."

312 PITOMBO, Cleunice A. Valentim Bastos, 2005, p. 239.
} 
Por fim, a última hipótese é a do encontro casual, que podemos dividir em duas modalidades, sendo a primeira a do encontro, durante a execução da medida, de coisas que não estão relacionadas com o processo que ensejou a medida de busca e a segunda a do encontro de coisas em locais públicos ou abertos ao público.

Em ambas as hipóteses, salvo no caso de flagrante delito, concordamos com a posição de Cleunice Pitombo de que a melhor solução é que os executores da busca - ou a autoridade policial, no caso de encontro em locais públicos ou abertos ao público preservem o local, impedindo que as coisas sejam retiradas ou ocultadas, e providenciem a respectiva autorização judicial para a apreensão de coisas em poder de terceiros.

\begin{abstract}
Merece maior reflexão, porém, o encontro casual, em virtude do cumprimento de mandado de busca e de apreensão domiciliar, se inexistente qualquer relação entre os motivos e finalidades determinantes da ordem originária e o achamento fortuito. [...] Em decorrência, pode-se afirmar que a apreensão de coisa encontrada ao acaso, sem relação com o fato investigado, resultante de busca legal, não pode ser realizada de pronto. Melhor que a autoridade policial preserve o local, providenciando autorização judicial, para que a tomadia se concretize, em plena legalidade. ${ }^{313}$
\end{abstract}

Se não for possível identificar o possuidor ou detentor das coisas achadas casualmente em locais públicos ou abertos ao público, não sendo necessária a inversão forçada da posse, entendemos que não há necessidade de ordem judicial para a apreensão, mas é imprescindível que se elabore o respectivo auto de apreensão, descrevendo a coisa detalhadamente, formalizando a apreensão e as respectivas condições em que foi encontrada e explicitando os motivos pelos quais foi impossível a identificação do possuidor ou detentor.

Por fim, cumpre destacar que o Código de Processo Penal disciplina, no parágrafo $2^{\circ}$ do artigo 243, que não podem ser apreendidos os documentos em poder do defensor do acusado, salvo quando constituírem elementos do corpo de delito. A referida restrição está corroborada pela nova redação do inciso II do artigo $7^{\circ}$ do Estatuto da Advocacia ${ }^{314}$, que determina que são invioláveis os instrumentos de trabalho do advogado e sua

313 PITOMBO, Cleunice A. Valentim Bastos, 2005, p. 266.

314 BRASIL. Lei $n^{\circ}$ 8.906, de 4 de julho de 1994. Dispõe sobre o Estatuto da Advocacia e a Ordem dos Advogados do Brasil (OAB). Disponível em: <http://www.planalto.gov.br/ccivil_03/leis/L8906.htm>. Acesso em: 8 jan. 2013. 
correspondência escrita, eletrônica, telefônica e telemática, além de seu escritório ou local de trabalho ${ }^{315}$.

\subsection{O PROCEDIMENTO DOS CRIMES CONTRA A PROPRIEDADE IMATERIAL}

O artigo 524 do Código de Processo Penal estabelece que se aplicam ao procedimento dos crimes contra a propriedade imaterial as regras previstas para $\mathrm{o}$ procedimento comum, com as modificações constantes dos artigos seguintes, que tornam especial o procedimento comum. O procedimento especial dos crimes contra a propriedade imaterial se difere do comum pela necessidade de que a produção antecipada de provas seja realizada antes do recebimento da denúncia ou da queixa-crime.

Tal produção antecipada de provas consiste necessariamente na busca e na apreensão de exemplares ou da totalidade dos objetos contrafeitos, conforme o caso, salvo nos crimes de concorrência desleal.

Isso porque, em regra, os crimes contra a propriedade imaterial deixam vestígios, e, por tal motivo, o artigo 525 do Código de Processo Penal estabelece que, no procedimento dos crimes contra a propriedade imaterial, a elaboração de exame de corpo de delito, por meio de laudo pericial devidamente homologado pelo juiz, é condição para o recebimento da denúncia ou da queixa-crime (ação penal de iniciativa pública ou privada, respectivamente).

Evidentemente, se a infração se consumou sem deixar vestígios, como só acontece nos crimes de desvio de clientela ou de concorrência desleal, o exame pericial é dispensado, podendo a materialidade do ilícito ser comprovada por outros elementos probatórios. ${ }^{316}$

\footnotetext{
${ }^{315}$ Redação dada pela Lei $\mathrm{n}^{0} 11.767 / 2008$. (BRASIL. Lei $n^{\circ} 11.767$, de 7 de agosto de 2008. Altera o art. $7^{\circ}$ da Lei $\mathrm{n}^{0}$ 8.906, de 4 de julho de 1994, para dispor sobre o direito à inviolabilidade do local e instrumentos de trabalho do advogado, bem como de sua correspondência. Disponível em: $<$ http://www.planalto.gov.br/ccivil_03/_Ato2007-2010/2008/Lei/ L11767.htm\#art1>. Acesso em: 8 jan. 2013).

${ }^{316}$ MIRABETE, Julio Fabbrini, 2005, p. 616.
} 
Dessa forma, a regra geral, tanto para os crimes de ação penal de iniciativa privada $^{317}$ como para os crimes de ação penal de iniciativa pública - a despeito do disposto no artigo 530-A do Código de Processo Penal, uma vez que o artigo 525 se aplica a ambos os procedimentos —, é que o exame pericial é medida imprescindível para a persecução penal em ambos os procedimentos dos crimes contra a propriedade imaterial.

\begin{abstract}
Este exame pericial é condição específica de procedibilidade para a queixacrime. Desprovida da perícia sobre a ocorrência da imitação ou reprodução da marca ou patente, a queixa-crime não goza de possibilidade jurídica: se for ajuizada sem o laudo conclusivo, não poderá ser recebida. ${ }^{318}$
\end{abstract}

Difere-se então, na forma dos artigos 530-A e 530-I do Código de Processo Penal, o procedimento dos crimes contra a propriedade imaterial de ação penal de iniciativa privada do procedimento dos crimes de ação penal de iniciativa pública, uma vez que aos primeiros aplicam-se as disposições dos artigos 526 a 530 e aos segundos, as disposições dos artigos 530-B a 530-H. As normas previstas nos artigos 524 e 525 são as disposições comuns a ambos os procedimentos.

\title{
4.3.1 O PROCEDIMENTO DOS CRIMES DE AÇÃO PENAL DE INICIATIVA PRIVADA
}

Inicialmente cumpre observar que o processo e o julgamento dos crimes de ação penal de iniciativa privada - artigo 184, caput, do Código Penal; artigo 12, caput, da Lei n 9.609/1998; e artigos 183 a 190 e 192 a 195 da Lei de Propriedade Industrial— são de competência dos Juizados Especiais Criminais, pois são crimes de menor potencial ofensivo, posto que as penas máximas abstratamente aplicadas não excedem um ano ${ }^{319}$.

317 Segundo entendimento firmado pelo STJ: "Ab initio, consoante entendimento adotado por esta Corte, a persecução penal dos denominados crimes contra a propriedade imaterial, que deixam vestígios, exige, como condição para o recebimento da queixa-crime, a demonstração prévia da existência da materialidade do delito atestada por meio da perícia técnica." (BRASIL. Superior Tribunal de Justiça. Recurso Especial n 336.553 - SP (2001/0094360-2). Relator: ministro José Arnaldo da Fonseca. Brasília, 20 fev. 2003. Disponível em: $<$ https://ww2.stj.jus.br/revistaeletronica/ita.asp?registro=200100943602 \&dt_publicacao=24/03/2003>. Acesso em: 5 jan. 2013).

318 SCHMIDT, Lelio Denicoli. A busca e apreensão nos crimes contra a propriedade industrial: requisitos para a concessão e responsabilidade pela execução. Revista da Associação Brasileira da Propriedade Intelectual, Rio de Janeiro, n. 43, p. 25-38, 1999. p. 29.

319 Com o advento da nova Lei de Propriedade Industrial (Lei n ${ }^{\circ}$ 9.279/1996), discutiu-se a competência para processar e julgar os crimes de ação penal de iniciativa privada, vez que a Lei $n^{0}$ 9.099/1995 é anterior àquela. Entretanto, com a promulgação da Lei 10.259/2001, a divergência foi superada, sedimentando-se o entendimento de que a competência para processar e julgar os crimes contra a propriedade imaterial no procedimento de iniciativa privada é dos Juizados Especiais Criminais. “A Lei 9.099/95 não era aplicável aos crimes contra a propriedade industrial. Todavia, a Lei 10.259/2001 tem irrecusável aplicação, mesmo 
Apesar de estarem submetidos ao procedimento especial previsto nos artigos 524 a 530 do Código de Processo Penal ${ }^{320}$, os crimes de ação penal de iniciativa privada estão abrangidos na nova redação dada ao artigo 61 da Lei $n^{\circ} 9.099 / 1995$ pela Lei $n^{\circ}$ $11.313 / 2006^{321}$, conforme entendimento sedimentado pelo Superior Tribunal de Justiça.

\begin{abstract}
A Lei n. ${ }^{\circ}$ 9.099/95 aplica-se aos crimes sujeitos a procedimentos especiais, desde que obedecidos os requisitos autorizadores, permitindo a transação e a suspensão condicional do processo inclusive nas ações penais de iniciativa exclusivamente privada. (CC 30.164/MG, $3^{\text {a }}$ Seção, rel. Min. GILSON DIPP, DJ de 04/03/2002, p. 178). ${ }^{322}$
\end{abstract}

\begin{abstract}
Se a nova lei não fez qualquer ressalva acerca dos crimes submetidos a procedimentos especiais, todas as infrações cuja pena máxima não exceda a dois anos, inclusive as de rito especial, passaram a integrar o rol dos delitos de menor potencial ofensivo, cuja competência é dos Juizados Especiais. (HC 32.924/SP, $5^{\text {a }}$ Turma, rel. Min. GILSON DIPP, DJ de 14/06/2004, p. 258). ${ }^{323}$
\end{abstract}

Segundo o procedimento previsto para as ações penais de iniciativa privada, o ofendido deve requer ao juiz a busca e a apreensão das coisas que serão objeto de perícia, uma vez que esta é condição necessária para a ação penal ${ }^{324}$. Assim, deve sempre existir uma produção antecipada de prova pericial sobre os objetos contrafeitos ou imitados, cujo pedido de apreensão deve necessariamente ser instruído com os quesitos que o ofendido pretende formular para os peritos.

porque esta última lei ampliou de muito, o rol dos crimes de menor potencial ofensivo, e é aplicável também nos juizados especiais criminais estaduais." (PIERANGELI, José Henrique. 2003, p. 402).

${ }^{320}$ Nesse sentido: VANZOLINI, Maria Patricia, 2004, p. 83.

${ }^{321}$ BRASIL. Presidência da República. Casa Civil. Subchefia para Assuntos Jurídicos. Lei no 11.313, de 28 de junho de 2006. Altera os arts. 60 e 61 da Lei $n^{\circ} 9.099$, de 26 de setembro de 1995, e o art. $2^{\circ}$ da Lei ${ }^{\circ}$ 10.259, de 12 de julho de 2001, pertinentes à competência dos Juizados Especiais Criminais, no âmbito da Justiça Estadual e da Justiça Federal. Disponível em: <http://www.planalto.gov.br/ccivil_03/ Ato2004-2006/2006/Lei/L11313.htm\#art2>. Acesso em: 5 jan. 2013.

322 BRASIL. Superior Tribunal de Justiça. Conflito de Competência $n^{\circ} 30.164$ - MG (2000/0078187-8). Relator: ministro Gilson Dipp. Brasília, 13 dez. 2001. Disponível em: <https://ww2.stj.jus.br/ revistaeletronica/ita.asp?registro $=200000781878 \& d t$ publicacao=04/03/2002>. Acesso em: 5 jan. 2013.

323 BRASIL. Superior Tribunal de Justiça. Habeas Corpus $n^{\circ} 32.924$ - SP (2003/0239367-1). Relator: ministro Gilson Dipp. Brasília, 28 abr. 2004. Disponível em: <https://ww2.stj.jus.br/revistaeletronica/ ita.asp?registro=200302393671\&dt_publicacao=14/06/2004>. Acesso em: 5 jan. 2013.

324 Apreciando o tema, o Supremo Tribunal Federal já teve oportunidade de destacar que a finalidade do artigo 525 do CPP "[...] não é tornar essencial a formalidade de a queixa, ao ser ajuizada, vir concomitantemente acompanhada do exame pericial, mas sim proibir que o recebimento da denúncia ocorra se, além da queixa, não houver nos autos o exame pericial dos objetos que constituam o corpo de delito.” (SCHMIDT, Lelio Denicoli, 1999, p. 29). No mesmo sentido, o Superior Tribunal de Justiça firmou entendimento: “Observa-se que a perícia, nestes casos, é indispensável para a propositura da ação penal. Logo, o juízo não poderia ter recebido queixa sem a juntada do laudo pericial." (BRASIL. Superior Tribunal de Justiça. Recurso Ordinário em Habeas Corpus $n^{\circ}$ 9,854 - PR (2000/0031836-1). Relator: ministro Jorge Scartezzini. Brasília, 13 set. 2000. Disponível em: <https://ww2.stj.jus.br/revistaeletronica/ ita.asp?registro=200000318361\&dt_publicacao=18/12/2000>. Acesso em: 5 jan. 2013). 
O artigo 526 do Código de Processo Penal ${ }^{325}$ determina que deve haver prova da legitimidade da posição do ofendido para que a queixa seja recebida ou para a realização de qualquer outra diligência preparatória para a ação penal. Isso significa que o ofendido deve comprovar, no pedido de busca e apreensão, a titularidade da patente, a autoria da obra, do programa de computador, etc. e seus respectivos registros, quando for o caso.

Em suma, deve haver prova do direito de exclusivo, na forma da legislação de propriedade intelectual atinente à espécie. "O dispositivo não passa de uma explicitação do que o CPP já dispõe em seu artigo 30, à luz do qual 'ao ofendido ou a quem tenha qualidade para representá-lo caberá intentar a ação privada'.,326.

Entretanto, não é apenas o próprio titular dos direitos de exclusivo que pode iniciar a ação penal de iniciativa privada, uma vez que os artigos 61 e 139 da Lei de Propriedade Industrial permitem, expressamente, que o proprietário do registro ou da patente outorgue ao licenciado poderes para agir na defesa do título em questão e atuar em nome próprio (legitimidade extraordinária) $^{327}$. Da mesma forma podem atuar as associações de titulares de direitos de autor e direitos conexos, conforme o disposto no artigo 97 da Lei $\mathrm{n}^{\mathrm{o}}$ 9.610/1998.

Preenchido o requisito de comprovação da titularidade do direito de exclusivo, o juiz determinará a busca e a apreensão de amostras do objeto incriminado, sobre as quais dois peritos nomeados pelo juiz realizarão a prova pericial.

Se a busca e a apreensão forem realizadas no curso de inquérito policial, conduzido por delegado de polícia, e ficar comprovado que o crime é de ação penal de iniciativa privada, nada impede o oferecimento de queixa-crime pelo ofendido. Nesse sentido, Lélio Schmidt defende que:

\footnotetext{
Nada impede que, instaurado um inquérito policial por crime contra a propriedade industrial (mesmo de ação penal privada), a autoridade policial encaminhe uma representação ao juiz para que este determine a perícia e nomeie as pessoas que deverão levá-la a cabo. Não haveria na espécie qualquer afronta ao artigo 527 do CPP. ${ }^{328}$
}

\footnotetext{
325 “Art. 526. Sem a prova de direito à ação, não será recebida a queixa, nem ordenada qualquer diligência preliminarmente requerida pelo ofendido."

326 SCHMIDT, Lelio Denicoli, 1999, p. 26.

327 Cf. SCHMIDT, Lelio Denicoli, 1999, p. 27.

328 SCHMIDT, Lelio Denicoli, 1999, p. 28.
} 
No transcorrer da diligência de busca, os peritos deverão analisar a existência de fundamento para a apreensão ou não de amostras do objeto incriminado, devendo, em ambas as hipóteses, apresentar, no prazo de três dias a contar do encerramento da diligência, laudo pericial fundamentado em que justifiquem a apreensão ou a não apreensão dos objetos incriminados.

Ao contrário do que ocorre nos crimes de ação penal de iniciativa pública, para os quais são apreendidos todos os objetos ilicitamente produzidos ou reproduzidos, na forma do artigo 530-B do Código de Processo Penal, no procedimento dos crimes de ação penal privada só podem ser apreendidos os exemplares estritamente necessários para a realização da perícia $^{329}$.

Caso os peritos entendam que não é caso de apreensão, consignando tais fundamentos no laudo pericial, pode o titular do direito de exclusivo impugnar o laudo elaborado, solicitando ao juiz que ordene a apreensão. Diante da referida impugnação, o juiz, por sua vez, deve proferir decisão fundamentada, reconhecendo ou não a improcedência das razões aduzidas pelos peritos no laudo pericial.

Quando os peritos entenderem que o caso é de apreensão, deverão apreender amostras do objeto incriminado, elaborando laudo pericial que aponte os elementos da contrafação. Após a apresentação do laudo, os autos serão conclusos ao juiz para a respectiva homologação.

A decisão que homologa o laudo, a favor ou contra o requerente, tem caráter definitivo, por isso contra ela cabe recurso de apelação.

Se o juiz indeferir o pedido de busca e apreensão caberá apelação, por se tratar
de decisão com força de definitiva (CPP, art. 593, II). No caso de o ofendido
apelar da decisão que indefere a busca e apreensão poderá surgir um problema
prático: de um lado, é necessária a perícia e a homologação de seu laudo, para o
recebimento da queixa e, de outro, o prazo decadencial, que não se suspende
nem se interrompe, estará correndo, durante o julgamento da apelação. A forma
de impedir a decadência será o oferecimento de queixa, com pedido de
sobrestamento do juízo de admissibilidade da acusação, até o julgamento da
apelação. Dessa forma, não estará sendo violado o art. 525 do CPP, que se refere

329 Cf. BADARÓ, Gustavo Henrique Righi Ivahy. Direito processual penal. Rio de Janeiro: Elsevier, 2009. tomo II. p. 173. 
ao recebimento da queixa e, por outro lado, com seu aforamento, já se evita a decadência. ${ }^{330}$

Proferida a decisão, os autos devem permanecer em cartório aguardando o início da ação penal, com o oferecimento da queixa-crime dentro do prazo decadencial. Caso o prazo decadencial transcorra sem o oferecimento de queixa-crime, o requerido poderá solicitar o levantamento das coisas apreendidas para a realização da perícia ${ }^{331}$.

Oferecida a queixa-crime dentro do prazo decadencial, esta será juntada aos autos da medida cautelar de produção antecipada de provas, que será levada à conclusão para o recebimento ou não da queixa-crime pelo juiz, que deve analisar o preenchimento dos requisitos do artigo 41 e seguintes do Código de Processo Penal.

O direito de queixa, nos crimes contra a propriedade imaterial, está sujeito à regra especial de decadência, que estabelece o prazo de 30 dias após a homologação do laudo para o oferecimento da queixa. Dessa forma, não será admitida queixa com fundamento em apreensão e perícia se decorrido esse prazo.

Portanto, até o ajuizamento de pedido de busca e apreensão, o prazo decadencial nos crimes contra a propriedade imaterial obedece à regra do artigo 38 do Código de Processo Penal e, a partir do ajuizamento da medida cautelar de produção antecipada de provas, à regra do artigo 529 do mesmo diploma legal.

Este é o entendimento já sedimentado pelo Superior Tribunal de Justiça:

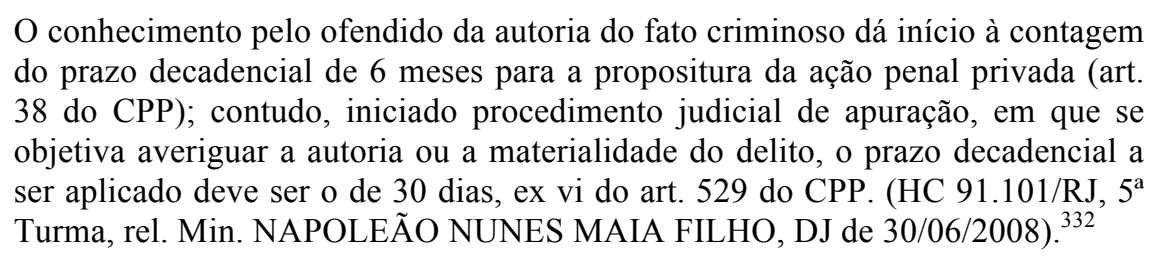

330 BADARÓ, Gustavo Henrique Righi Ivahy. 2009, p. 172.

331 “As diligências de busca e apreensão podem ser requeridas como preliminares da ação penal e das ações negatória e de perdas e danos, sendo lícito à parte utilizar-se delas para instruir estas ações, se por uma delas optar. Mas a busca e apreensão realizadas no juízo cível não poderão servir de base para o processocrime.” (CERQUEIRA, João da Gama. 2010c, p. 213).

332 BRASIL. Superior Tribunal de Justiça. Habeas Corpus $n^{\circ} 91.101$ - RJ (2007/0223578-5). Relator: ministro Napoleão Nunes Maia Filho. Brasília, 17 jun. 2008. Disponível em: $<$ https://ww2.stj.jus.br/revistaeletronica/ita.asp?registro=200702235785\&dt_publicacao=30/06/2008>. Acesso em: 5 jan. 2013. 
Nos casos de réu preso, o prazo previsto no artigo 529, caput, será de oito dias ${ }^{333}$, e não 30, para a propositura de queixa-crime.

Todavia, diante do disposto no art. 530-A do CPP, [...] a hipótese do art. 529, parágrafo único, restou esvaziada, posto que somente seria aplicável em crime de ação penal pública no qual houvesse requerimento de busca e apreensão. Diante da Lei ${ }^{0} 10.695 / 2003$, o art. 529 não mais se aplica aos crimes de ação penal pública, que se sujeitam ao procedimento dos arts. $530-\mathrm{B}$ a $530-\mathrm{H}^{334}$

\subsubsection{O PROCEDIMENTO DOS CRIMES DE AÇÃO PENAL PÚBLICA}

A Lei $n^{\circ} 10.695 / 2003$ disciplinou que os crimes descritos nos parágrafos $1^{\circ}, 2^{\circ}$ e $3^{\circ}$ do artigo 184 do Código Penal são crimes de ação penal de iniciativa pública, na forma dos incisos II e IV do artigo 186 do mesmo diploma legal, sendo os dois primeiros de ação penal de iniciativa pública incondicionada e o terceiro de ação penal de iniciativa pública condicionada à representação.

Se o crime é cometido em prejuízo de entidade de direito público, autarquia, empresa pública, sociedade de economia mista ou fundação instituída pelo poder público, a ação será sempre de iniciativa pública incondicionada, qualquer que seja a conduta típica praticada, conforme dispõe o inciso III do artigo 186 do Código Penal.

Dessa forma, nos casos de crimes de ação penal de iniciativa pública, sejam eles os previstos nos parágrafos $1^{\circ}, 2^{\circ}$ e $3^{\circ}$ do artigo 184 do Código Penal, sejam os previstos no inciso II do parágrafo $3^{\circ}$ do artigo 12 da Lei $n^{\circ} 9.609 / 1998$ ou no artigo 191 da Lei $n^{\circ}$ 9.279/1996, o procedimento será o previsto no artigo 530-I do Código de Processo Penal, com a ressalva de que também se aplicam os artigos 524 e 525 do mesmo diploma legal.

Para esses crimes, a autoridade policial poderá instaurar inquérito policial ante a notícia da infração penal, exigindo-se representação apenas na hipótese do parágrafo $3^{\circ}$ do artigo 184 do Código Penal, conforme dispõe o inciso IV do artigo 186 do mesmo diploma legal.

\footnotetext{
333 "Art. 530. Se ocorrer prisão em flagrante e o réu não for posto em liberdade, o prazo a que se refere o artigo anterior será de 8 (oito) dias."

334 BADARÓ, Gustavo Henrique Righi Ivahy. 2009, p. 178.
} 
Independentemente da instauração ou não de inquérito policial, a primeira providência prevista no procedimento é a apreensão de todos os bens ilicitamente produzidos ou reproduzidos, juntamente com equipamentos, suportes e materiais que possibilitaram a sua existência, desde que precipuamente destinados a tal fim, na forma do artigo 530-B do Código de Processo Penal.

\begin{abstract}
Ao ter conhecimento do cometimento de quaisquer das condutas previstas [...] a autoridade policial deverá, de ofício (ressalvada a necessidade de representação do ofendido no caso do $\S 3^{\circ}$ ), proceder conforme determina o dispositivo: apreender o produto da contrafação, bem como os equipamentos, suportes e materiais empregados principalmente na prática da contrafação. ${ }^{335}$
\end{abstract}

Após a realização da apreensão, será lavrado o respectivo termo, que deverá ser assinado por duas ou mais testemunhas e conter a descrição de todos os bens apreendidos e as informações sobre as origens destes ${ }^{336}$. Esse termo deverá ser juntado aos autos do inquérito policial ou do processo, conforme o caso.

\footnotetext{
Diversamente do que determina o art. 527, do CPP (que cuida da busca e apreensão de bens contrafeitos nos crimes de ação penal privada), aqui não se exige que a diligência seja realizada por perito. Ao contrário, o artigo atribui expressamente à autoridade policial o dever de realizá-la. ${ }^{337}$
}

Não podemos deixar de ressalvar que, apesar de o dispositivo prever que a autoridade policial procederá à apreensão dos bens ilicitamente produzidos ou reproduzidos, essa autoridade não está autorizada a realizar qualquer medida de busca sem mandado, uma vez que devem ser respeitadas as regras previstas nos artigos $240 \mathrm{e}$ seguintes do Código de Processo Penal, que impõem a necessidade de ordem judicial fundamentada.

Por se tratar de crimes que se apuram mediante ação penal de iniciativa pública, assim que a apreensão tiver sido realizada pela autoridade policial será feita a perícia, por perito oficial ou por pessoa tecnicamente habilitada, sobre os bens apreendidos - uma amostra de cada objeto incriminado —, elaborando-se o respectivo laudo, que deverá integrar o inquérito policial.

\footnotetext{
335 VANZOLINI, Maria Patricia, 2004, p. 83.

${ }^{336}$ Cf. BADARÓ, Gustavo Henrique Righi Ivahy. 2009, p. 180.

337 VANZOLINI, Maria Patricia, 2004, p. 83.
} 
Apesar de o procedimento prever, no artigo 530-D do Código de Processo Penal, que a perícia será realizada por perito oficial ou, na falta deste, por pessoa tecnicamente habilitada (permitindo o entendimento de que basta uma pessoa tecnicamente habilitada para executar essa tarefa), a prova pericial tem tipo processual previsto nos artigos $158 \mathrm{e}$ seguintes do Código de Processo Penal, logo, deve sempre ser realizada por um perito oficial portador de diploma de curso superior ou, na sua falta, por duas pessoas idôneas portadoras de diploma de curso superior ${ }^{338}$.

Outro problema, decorrente da falta de precisão na redação do artigo 530-D do Código de Processo Penal, é que o dispositivo estabelece que o laudo deverá integrar o inquérito ou o processo, permitindo a interpretação de que o processo pode ser iniciado antes da conclusão do laudo pericial.

Entretanto, tal previsão não tem o condão de revogar o artigo 525 do mesmo diploma legal, que não foi alterado pela Lei $n^{0} 10.695 / 2003$ e exige o exame de corpo de delito como condição para o início da ação penal. Sendo assim, o laudo precede o processo e só poderá integrá-lo quando os autos do inquérito policial forem anexados à denúncia.

Uma inovação introduzida pela Lei $n^{0} 10.695 / 2003$ foi a determinação de que os titulares dos direitos de exclusivo serão os fiéis depositários dos bens apreendidos, devendo colocá-los à disposição do juízo quando do início da ação penal. Tal dispositivo - artigo 530-E do Código de Processo Penal - transferiu o ônus de armazenar os bens ilicitamente produzidos ou reproduzidos ao titular do direito violado.

Por outro lado, uma vez que tais bens apreendidos - resultantes de produção ou reprodução ilegal - devem ser armazenados pela vítima, que arca com o ônus da armazenagem, da guarda e da conservação, permite-se, em contrapartida, que a vítima requeira autorização judicial para proceder à destruição antecipada quando não houver impugnação quanto à ilicitude dos bens ou quando não puder ser identificado o autor da infração penal.

${ }^{338}$ Em sentido contrário: VANZOLINI, Maria Patricia, 2004, p. 85. 
A destruição antecipada dos bens apreendidos poderá ocorrer mesmo que não haja condenação, desde que preservadas as amostras suficientes para a preservação do corpo de delito e suas posteriores comprovações.

\begin{abstract}
No primeiro caso, poderão ser destruídos bens lícitos, caso assim se conclua ao final do processo. Por outro lado, não se sabendo quem foi o autor do ato ilícito, poderá ser determinada a destruição de bens de terceiros de boa-fé, que não tenham tido a oportunidade de impugnar a apreensão. Tais disposições guardam correlação com o art. 530-G, que estabelece uma modalidade especial de efeito secundário da sentença penal condenatória. ${ }^{339}$
\end{abstract}

Segundo Julio Fabbrini Mirabete, na sentença penal condenatória o juiz poderá determinar: “[...] a destruição dos bens ilicitamente produzidos ou reproduzidos, que podem abranger não apenas os que já tenham sido apreendidos, mas também aqueles cuja apreensão for ordenada." 340 .

Aqui, não nos parece que exista qualquer possibilidade senão a destruição dos bens ilicitamente produzidos ou reproduzidos, uma vez que eles não podem ser perdidos em favor da Fazenda Nacional, porque violam em si a propriedade imaterial, e, de igual sorte, não podem ser entregues ao titular do direito de exclusivo, porque a reprodução não foi por ele autorizada ${ }^{341}$.

Na sentença penal condenatória, o juiz poderá, também, decretar o perdimento, em favor da Fazenda Nacional, de equipamentos e outros instrumentos destinados precipuamente à prática do crime. Ficará a cargo da Fazenda Nacional destruir ou doar para os Estados, os municípios e o Distrito Federal ou incorporar ao patrimônio da União as coisas perdidas em seu favor por economia ou interesse público. Em qualquer hipótese, fica proibido o retorno dos bens aos canais de comércio.

Por fim, o procedimento prevê que, tratando-se das infrações penais previstas nos parágrafos $1^{\circ}, 2^{\circ}$ e $3^{\circ}$ do artigo 184 do Código Penal, as associações de titulares de direitos de autor e conexos estão legitimadas a intervir na ação penal na qualidade de assistentes de acusação quando o crime for praticado em detrimento de qualquer de seus associados.

339 BADARÓ, Gustavo Henrique Righi Ivahy. 2009, p. 181.

340 MIRABETE, Julio Fabbrini, 2005, p. 619.

${ }^{341}$ A única hipótese prevista na legislação brasileira na qual os bens apreendidos cuja produção ou reprodução é ilícita têm destinação diversa da destruição diz respeito às apreensões cíveis de impressões de edições não autorizadas de obras literárias, artísticas ou científicas, que serão pedidas para o autor, na forma do artigo 103, parágrafo único, da Lei $n^{\circ} 9.610 / 98$. 
Criou-se aqui uma hipótese de legitimidade para as associações de titulares de direitos de autor e conexos se habilitarem como assistente de acusação ${ }^{342}$, como forma clara de evitar que o titular do direito de exclusivo tivesse de se fazer representar em juízo nessas circunstâncias. Permite-se, assim, a defesa dos direitos patrimoniais de autor sem que as respectivas empresas, que detêm tais direitos, tenham de figurar como algozes dos contrafatores, evitando a condescendência dos magistrados.

Segundo o ex-presidente da Associação dos Magistrados Brasileiros, os casos que normalmente chegam à justiça criminal por ação da própria empresa são vistos pelos juízes da seguinte forma: “[...] empresas poderosas economicamente têm de se virar de outra forma e não será colocando a Justiça Penal para reprimir pequenos [...] pessoas que estão tentando sobreviver que vamos chegar a algum lugar."343.

\subsubsection{A APREENSÃo NOS CRIMES DE AÇÃO PENAL PRIVADA}

$\mathrm{Na}$ ação penal de iniciativa privada o ofendido deve requerer ao juiz a busca e a apreensão das coisas que serão objeto do exame pericial, oferecendo desde logo seus quesitos. A busca será realizada então por dois peritos nomeados pelo juiz, que têm o poder de decidir, durante a diligência, sobre a existência de fundamento para a apreensão da coisa ou não ${ }^{344}$.

A apreensão será realizada exclusivamente sobre tantos exemplares quantos forem estritamente necessários para a realização da perícia e a eventual comprovação do delito. Entretanto, diversos autores tentam justificar o entendimento de que, como forma de

${ }^{342}$ Nesse sentido: BADARÓ, Gustavo Henrique Righi Ivahy. 2009, p. 180.

${ }^{343}$ COLLAÇO, Rodrigo, 2007, p. 51.

344 "A execução de uma busca e apreensão deferida em sede cível torna o requerente objetivamente responsável pela indenização dos prejuízos causados, caso perca a demanda. O mesmo, porém, não ocorre no processo penal, que se rege por normas diversas. [...] Para que haja responsabilidade, não basta que o resultado da busca criminal tenha sido negativo. A este elemento objetivo, há de somar-se o elemento subjetivo consistente na má-fé, emulação, capricho ou erro grosseiro (note-se, não qualquer erro, mas sim um erro crasso, elementar). Caso este elemento subjetivo não tenha estado presente, o requerimento de busca e apreensão nada mais terá sido do que o exercício lícito e regular do direito à produção de prova, ou seja, do direito que a parte tem quanto à colheita de elementos probatórios quanto às alegações feitas. Não se aplica aqui, portanto, o sistema de responsabilidade objetiva que vige no processo civil para o requerente da medida." (SCHMIDT, Lelio Denicoli, 1999, p. 35). 
impedir a continuidade da infração, as apreensões devem abranger todos os objetos contrafeitos.

\begin{abstract}
Vasta jurisprudência sustenta que o montante de objetos apreendidos deve ser ínfimo, restrito à quantidade necessária para a comprovação da materialidade do delito. Não seria cabível a apreensão total dos objetos contrafeitos. Em sentido contrário posicionam-se José Carlos Tinoco Soares e Hermano Durval, bem como o aresto constante da RT 645/273. O fundamento é a necessidade de impedir a continuidade da infração e o fato de que cada unidade contrafeita caracteriza per si uma violação ao direito de propriedade imaterial. [...] É importante compreender este aspecto, pois tanto o DL 7.903/45 quanto a Lei de Propriedade Industrial deram à busca e apreensões funções mais amplas do que a originalmente contemplada pelo $\mathrm{CPP}$, procurando não só caracterizar a materialização do delito, mas também e sobretudo impedir a sua continuidade. ${ }^{345}$
\end{abstract}

Uma vez que no procedimento dos crimes contra a propriedade imaterial de ação penal privada a apreensão foi disciplinada exclusivamente como meio de obtenção de provas, de caráter cautelar e instrumental, como medida preparatória para a ação penal, não é possível lhe atribuir uma função satisfativa, destinada a impedir a continuidade do delito.

No procedimento dos crimes de ação penal privada, não é necessária a instauração de inquérito policial, e a busca e a apreensão igualmente não estão sujeitas ao contraditório, como forma de evitar que as medidas sejam inócuas e ineficazes ${ }^{346}$.

\begin{abstract}
A oitiva da parte contrária é vedada antes da efetivação da medida, pois frustraria a surpresa que é imprescindível à coleta fiel da prova e permitiria o perecimento desta. O contraditório não é suprimido: fica apenas postergado para a queixa-crime a ser posteriormente proposta. ${ }^{347}$
\end{abstract}

Por outro lado, o procedimento estabelece que a parte que tiver requerido busca e apreensão por má-fé, emulação, capricho ou erro grosseiro responde por perdas e danos causados àquele que sofreu a medida. Mais do que isso, o artigo 203 da Lei de Propriedade Industrial estabelece que as medidas de busca e apreensão realizadas em estabelecimentos comerciais ou industriais legalmente organizados devem ser limitadas à vistoria e à apreensão dos produtos, não podendo ser paralisada a atividade legalmente exercida.

\footnotetext{
345 SCHMIDT, Lelio Denicoli, 1999, p. 32.

346 “Os peritos deverão responder aos quesitos formulados pelo ofendido, quando do requerimento da busca e apreensão. O Ministério Público e o próprio juiz também poderão elaborar quesitos. Nesse primeiro momento, a parte contrária não formula quesitos, por se tratar de diligência inaudita altera pars." (BADARÓ, Gustavo Henrique Righi Ivahy. 2009, p. 173).

347 SCHMIDT, Lelio Denicoli, 1999, p. 33.
} 
Podemos, então, destacar que a medida de busca e apreensão do procedimento dos crimes de ação penal privada é estabelecida nos moldes das medidas de busca e apreensão do procedimento comum, uma vez que se configuram como medidas cautelares nitidamente instrumentais, com a função exclusiva de meio de obtenção de provas.

\subsubsection{A APREENSÃo NOS CRIMES DE AÇÃO PENAL PÚBLICA}

Nos crimes contra a propriedade imaterial de ação penal de iniciativa pública dispensa-se a intervenção necessária da vítima, uma vez que a autoridade policial poderá instaurar inquérito policial em virtude da notitia criminis, ressalvada apenas a necessidade de representação na hipótese do parágrafo $3^{\circ}$ do artigo 184 do Código Penal.

\footnotetext{
O "novo" procedimento especial nada mais fez do que afastar a necessidade de o ofendido requerer a busca e apreensão dos bens contrafeitos e de o juiz homologar o laudo elaborado em razão de tal apreensão (CPP, art. 524). Pelo novo procedimento, haverá busca e apreensão dos bens ilícitos pela autoridade policial (CPP, art. 530-B) e a elaboração de um laudo que deverá acompanhar o inquérito policial (CPP, art. 530-D). ${ }^{348}$
}

A apreensão, nessa hipótese de ação penal de iniciativa pública, poderá recair sobre todos os bens ilicitamente produzidos ou reproduzidos e sobre equipamento, suporte ou material utilizado no cometimento da infração, desde que estes se destinem precipuamente à prática do ilícito.

Os bens apreendidos serão relacionados minuciosamente em termo próprio devidamente assinado por duas testemunhas, e os titulares dos direitos de exclusivo serão nomeados como fiéis depositários dos bens apreendidos.

A apreensão de todos os bens ilicitamente produzidos ou reproduzidos não se justifica como um instrumento processual, vez que bastaria a apreensão de tantos exemplares quantos fossem necessários para a realização de exame pericial, na forma da regra geral das apreensões; todavia, aqui se permite a apreensão de todos os bens ilicitamente produzidos ou reproduzidos.

348 BADARÓ, Gustavo Henrique Righi Ivahy. 2009, p. 178-179. 
Ademais, apesar de a destruição ser, em regra, efeito da sentença penal condenatória transitada em julgado, o Código de Processo Penal permite a destruição antecipada dos bens apreendidos quando não houver impugnação quanto à ilicitude destes ou, mesmo sem processo, quando não for possível iniciar a ação penal por falta de conhecimento da autoria do delito.

[...] os bens apreendidos, resultantes de produção ou reprodução ilegal, poderão ser destruídos, a requerimento da vítima, mesmo na ausência de condenação, na hipótese de inexistência de impugnação quanto à sua ilicitude ou quando a ação penal não puder ser proposta por desconhecimento da autoria do ilícito (art. 530G). ${ }^{349}$

Logo, a medida de destruição antecipada tem por escopo desonerar os titulares de direitos de exclusivo do ônus de fiel depositário nas situações descritas anteriormente.

Sendo assim, tais medidas cumprem uma função que não se justifica pelo processo ou para o processo; logo, essa apreensão não é uma medida instrumental nem mesmo uma medida cautelar.

Da mesma forma, é absolutamente inadmissível, em face do princípio da presunção de inocência, aceitar que as apreensões nesses casos sejam medidas antecipatórias penais que têm por escopo impedir a reiteração da prática delituosa, como sustentam alguns autores, ou cujo objetivo é antecipar um efeito — perdimento e destruição — da sentença penal condenatória.

Diante da impossibilidade de determinar a natureza jurídica das apreensões no procedimento dos crimes contra a propriedade imaterial de ação penal pública como medidas cautelares ou meios de obtenção de prova, passaremos a analisar a natureza jurídica de tais medidas, sem correr o risco de justificá-las como medidas de segurança social ou medidas antecipatórias penais ${ }^{350}$.

${ }^{349}$ MIRABETE, Julio Fabbrini. Processo Penal. 17. ed. São Paulo: Atlas, 2005. p. 619.

350 "No CPP, a busca e apreensão em matéria de propriedade industrial foi concebida com a única função de comprovar a materialidade do delito. Leis posteriores, porém, ampliaram este espectro, como é o caso da Lei 9.279/96 (e, antes desta, do DL 7.903/45) dando a esta medida uma feição cautelar, com vistas a impedir a consumação, exaurimento ou continuidade da lesão, como se nota do artigo 202 da LPI. Sob esta ótica, a apreensão há de abranger a totalidade dos produtos contrafeitos, para evitar que os mesmos sejam distribuídos e propiciar a sua posterior destruição." (SCHMIDT, Lelio Denicoli, 1999, p. 38). 


\title{
CAPÍTULO V - A APREENSÃO COMO MEDIDA SATISFATIVA
}

\subsection{Medidas CAUTELARES E MEDIDAS SATISFATIVAS}

A garantia constitucional da tutela jurisdicional impõe, ao mesmo tempo, o respeito ao devido processo legal e a prestação jurisdicional tempestiva. Em outras palavras, a tutela jurisdicional deve ser proferida por meio de um procedimento que respeite as garantias processuais das partes e que tal procedimento seja realizado em tempo hábil para que o provimento final seja útil e eficaz.

Entretanto, como o procedimento se realiza por meio de uma sucessão de atos concatenados, que são predispostos de forma ordenada para assegurar todas as garantias processuais das partes - em especial o contraditório, a ampla defesa e a paridade de armas -, não há como se exigir que o processo se realize instantaneamente.

\begin{abstract}
A garantia constitucional da tutela jurisdicional somente se cumpre efetivamente se forem asseguradas plenas condições de obtenção tempestiva da proteção requerida. Isso pressupõe o poder de pleitear a adoção, de medidas idôneas e suficientes para adequar, em tempo hábil, a situação de fato à realidade jurídica afirmada. São providências destinadas a eliminar os inconvenientes causados pelos efeitos do tempo necessário à plena cognição dos fatos e fundamentos desse suposto direito. ${ }^{351}$
\end{abstract}

Tais providências podem ser divididas em dois grupos: o primeiro é o das medidas necessárias para assegurar a viabilidade da realização dos atos processuais e a eficácia do provimento jurisdicional (medidas cautelares), e o segundo é o das medidas destinadas a tutelar o próprio direito material, antecipando o provimento jurisdicional final (antecipações de tutela).

Cândido Rangel Dinamarco sintetizou bem a diferença entre as medidas cautelares e as antecipações de tutela:

As antecipações de tutela não são instrumentais ao processo, não se destinam a
outorgar-lhe a capacidade de ser justo e útil (o que constitui missão das
cautelares), mas a fornecer ao sujeito aquilo mesmo que ele pretende obter ao
fim. ${ }^{352}$

351 BEDAQUE, José Roberto dos Santos. Tutela cautelar e tutela antecipada: tutelas sumárias e de urgência. 3. ed. São Paulo: Malheiros, 2003, p. 81-82.

352 DINAMARCO, Cândido Rangel. O regime jurídico das medidas urgentes. Revista Jurídica, Porto Alegre, v. 49 , n. 286, p. 271-302, ago. 2001. 
Em definição mais completa e aprofundada, José Carlos Barbosa Moreira distinguiu as duas medidas da seguinte forma:

\begin{abstract}
Afastando de caso pensado preocupações puramente terminológicas, lembraremos que se impõe distinguir, segundo já tem feito a doutrina, entre duas entidades, dois tipos de remédios que às vezes se veem confundidos. Um deles tende a assegurar de modo imediato a eficácia do próprio processo, e só indiretamente protege o direito substantivo litigioso; assim, não postula a cabal demonstração da existência deste, e por outro lado é utilizável ainda quando ele já tenha sido lesado, objetivando ai evitar, não, é óbvio, o dano decorrente da lesão, mas um segundo dano, consistente na supressão ou na redução dos meios de que se dispõe para tentar compor o primeiro. O outro tipo visa a proteger de maneira direta a situação material em si, razão porque a providência judicial descansará no prévio acertamento do direito (lato sensu) e jamais assumirá feição de provisoriedade, nem podendo qualificar-se de instrumental senão no sentido genérico em que o é todo o processo mas apresentando em qualquer caso caráter definitivo - ou, se quisermos usar a linguagem tipicamente carneluttiana, "satisfativo"353.
\end{abstract}

Sendo assim, podemos diferenciar as medidas cautelares das medidas satisfativas, porque as primeiras visam tutelar o próprio processo, assegurando-lhe o regular desenvolvimento, ou a eficácia do provimento jurisdicional final, enquanto as segundas visam antecipar os efeitos da sentença definitiva.

Contudo, partindo da premissa de que somente a dialética processual pode permitir a entrada de elementos de prova idôneos ao efetivo conhecimento da causa, as medidas urgentes serão sempre embasadas em um juízo de menor probabilidade que o proferido ao final do processo. Por esse motivo, deve existir, como já ressaltou Cândido Rangel Dinamarco, um "sistema de freios e contrapesos dos riscos" 354 dessas decisões proferidas com um conhecimento superficial da causa.

Para as medidas cautelares, o sistema de freios e contrapesos se resume no necessário preenchimento dos dois requisitos essenciais: fumus boni iuris e periculum in mora.

No intervalo entre o nascimento da relação jurídica processual e a obtenção do provimento final, existe sempre o risco de sucederem eventos que comprometam a atuação jurisdicional ou afetem profundamente a eficácia e utilidade do julgado. Há, então, a necessidade de medidas cautelares, que eliminem ou

${ }^{353}$ BARBOSA MOREIRA, José Carlos. Temas de direito processual: segunda série. São Paulo: Saraiva, 1988. p. 25.

${ }^{354}$ DINAMARCO, Cândido Rangel, 2001, p. 261. 
amenizem esse perigo. São providências urgentes, com as quais se busca evitar que a decisão da causa, ao ser obtida, não mais satisfaça o direito da parte e não realize, assim, a finalidade instrumental do processo, consistente em uma prestação jurisdicional justa. Em regra, tais medidas dependem da presença de dois pressupostos essenciais: o periculum in mora e o fumus boni iuris. ${ }^{355}$

O fumus boni iuris consiste na verossimilhança ou na probabilidade da existência de fundamento do direito alegado, e o periculum in mora consiste na demonstração de que o tempo do processo frustrará a eficácia ou utilidade do provimento final ou de que algum fator deturpará o regular desenvolvimento do processo. Entretanto, no processo penal, a existência do requisito do periculum in mora ainda suscita questionamentos.

\begin{abstract}
Os estudos sobre a cautelaridade no processo penal têm sido feitos a partir dos ensinamentos vindos do processo civil e grandes têm sido as dificuldades: além das dúvidas já encontradas nas construções doutrinárias dos processualistas civis, surgem problemas adicionais derivados da tentativa de serem adaptadas às exigências do processo criminal. Lembre-se, por exemplo, a dificuldade em se identificar o "periculum in mora" nas medidas cautelares reais penais. ${ }^{356}$
\end{abstract}

As antecipações de tutela ou medidas satisfativas, por sua vez, prescindem de prova inequívoca que convença da verossimilhança da alegação e fundado receio de dano irreparável ou de difícil reparação. Portanto, devem estar embasadas em um juízo de maior probabilidade que o necessário à concessão das medidas cautelares.

Porém, no processo penal, à luz do princípio da presunção de inocência, podemos aceitar o julgamento antecipado do processo, com a supressão da instrução processual, apenas nos casos de absolvição sumária, não sendo constitucionalmente lícitas, em respeito ao mencionado princípio, quaisquer hipóteses de condenação sumária.

Por esse raciocínio, no processo penal, podemos conceber e aceitar a existência de medidas cautelares que se justificam como formas de proteger o próprio processo e seus resultados, entretanto não podemos aceitar a antecipação do provimento jurisdicional condenatório, i.e., medidas antecipatórias penais que importem em qualquer forma de supressão do princípio da presunção de inocência.

\footnotetext{
355 FERNANDES, Antonio Scarance. Processo penal constitucional. 6. ed. São Paulo: Revista dos Tribunais, 2010. p. 279.

356 FERNANDES, Antonio Scarance. O papel da vitima no processo criminal. São Paulo: Malheiros, 1995. p. 191.
} 
Assim, o processo penal deve ser um instrumento que assegura as garantias previstas ao imputado, permitindo, por meio do procedimento previsto, alcançar uma solução com o maior grau de certeza possível no menor lapso temporal. Contudo, apesar de todo processo consumir tempo e de, durante esse período, poderem surgir situações excepcionais que tornem necessário proteger o próprio processo ou a eficácia de seu provimento final por meio de medidas cautelares, nenhuma destas pode expressar qualquer tipo de juízo condenatório.

Por outro lado, como veremos a seguir, podem existir situações em que se admite a adoção de medidas satisfativas no processo penal, que antecipem parte do provimento final, ou seja, medidas que antecipem um capítulo da sentença, seja ela condenatória, seja absolutória, sobre o confisco, o perdimento ou a destruição de coisas cujo fabrico, alienação, porte ou detenção constitua fato ilícito em si.

\subsection{AS COISAS QUE NÃO PODEM SER RESTITUÍDAS}

O Código Penal estabelece duas formas de confisco como efeito da condenação, sendo a primeira o confisco de instrumentos do crime — desde que consistam em coisas cuja fabricação, alienação, uso, porte ou detenção sejam, por si só, ilícitas — e a segunda, do produto do crime ou de qualquer bem ou valor que constitua proveito auferido pelo agente com a prática criminosa.

Por sua vez, o artigo 100 da redação original do Código Penal estabelecia que o juiz, em casos de absolvição, embora não apurada a autoria, deveria ordenar o confisco dos instrumentos e dos produtos do crime cujo fabrico, alienação, uso, porte ou detenção constituísse fato ilícito. Afinal, seria um contrassenso o próprio Estado, no exercício da função jurisdicional, determinar a restituição de coisas cuja fabricação, cuja venda, cujo uso, cujo porte ou cuja detenção constituísse ilícito autônomo.

Nelson Hungria, ao analisar essas duas hipóteses de confisco especial, classificou a primeira (em casos de condenação) como efeito penal da condenação e a segunda (em casos de absolvição, impronúncia e arquivamento de inquérito policial) como medida de segurança patrimonial. Vejamos: 
O confisco especial, entretanto, tendo por exclusivo objeto os instrumenta et producta sceleris, figura em tôdas as legislações modernas, ora como pena acessória, ora como efeito penal da condenação, ou como efeito civil do crime (Código uruguaio), ou, mais recentemente, como medida de segurança. Como efeito automático da condenação, já figurava êle no Código de 1890 (art. 69). O Código vigente adotou um critério dúplice, divergindo, neste particular, dos Códigos italiano e suíço, seus modelos preferidos: se há condenação do réu, o confisco especial se considera efeito necessário desta (art. 74, II, $a$ e $b$ ); se sobrevém absolvição (por qualquer motivo), e ainda mesmo no caso em que se não tenha apurado a autoria do crime, arquivando-se o inquérito policial, o confisco, limitado aos instrumentos e produtos do crime "que consistam em coisas cujo fabrico, alienação, uso, porte ou detenção constitui fato ilícito", figura entre as medidas de segurança patrimoniais (art. 100). ${ }^{357}$

Esse confisco em casos de absolvição, classificado por Nelson Hungria como medida de segurança patrimonial, está adstrito aos objetos cuja fabricação, cuja venda, cujo uso, cujo porte ou cuja detenção constitua ilícito - por exemplo, as armas ilegais, a moeda falsa, os documentos falsificados, as substâncias entorpecentes e as mercadorias contrafeitas. Nos demais casos, quando os instrumentos ou os produtos do crime não forem proibidos por si mesmos, o confisco só pode ser imposto como efeito necessário da condenação ${ }^{358}$.

Entretanto, a regra que estabelecia o confisco-medida de segurança ${ }^{359}$ não foi repetida na redação vigente do Código Penal, alterada pela Lei $n^{0} 7.209 / 84^{360}$, que reformou integralmente a parte geral do código. Por outro lado, permanece vigente o artigo 779 do Código de Processo Penal, que determina que "O confisco dos instrumentos e produtos do crime, no caso previsto no art. 100 do Código Penal, será decretado no

${ }^{357}$ HUNGRIA, Nelson. Comentários ao código penal (Dec.-lei $n^{\circ}$ 2.848, de 7 de dezembro de 1940). 4. ed. Rio de Janeiro: Forense, 1959. v. 3. p. 277.

${ }^{358} \mathrm{O}$ confisco como efeito da condenação não se confunde com a pena de confisco, cuja distinção já foi examinada por Alceu Corrêa Junior, conforme trecho transcrito a seguir: "As espécies de confisco penal não se confundem, pois no primeiro caso caracteriza-se como pena em sentido estrito e no segundo como efeito da condenação criminal. A pena de confisco é espécie de sanção penal pecuniária que deve ser cominada abstratamente pela lei, seja como pena principal ou acessória, e aplicada judicialmente em decorrência de uma infração penal, observado o devido processo legal. Por outro lado, o confisco especial é efeito extrapenal da condenação criminal e atinge apenas os instrumentos utilizados na prática do delito (instrumenta sceleris), bem como o produto direto e indireto deste (producta sceleris). Ressalte-se que o confisco especial geralmente incide apenas sobre instrumentos de uso ilícito, ou seja, aqueles cuja fabricação, alienação, uso, porte ou detenção constitua fato ilícito." (CORRÊA JUNIOR, Alceu. Confisco penal: alternativa à prisão e aplicação aos delitos econômicos. São Paulo: IBCCRIM, 2006. (Monografias, 37). p. 39.

359 Terminologia utilizada por Nelson Hungria. (HUNGRIA, Nelson, 1959, p. 279).

360 BRASIL. Lei $n^{\circ} 7.209$, de 11 de julho de 1984. Altera dispositivos do Decreto-Lei $\mathrm{n}^{\circ} 2.848$, de 7 de dezembro de 1940 - Código Penal, e dá outras providências. Disponível em: <http://www.planalto.gov.br/ccivil_03/leis/1980-1988/L7209.htm>. Acesso em: 14 jan. 2013. 
despacho de arquivamento do inquérito, na sentença de impronúncia ou na sentença absolutória.".

Apesar da ausência de norma que discipline a matéria, nos parece que a melhor solução seria aplicar a regra prevista no revogado artigo 100 do Código Penal como norma implícita do sistema, mantendo sua congruência e sua lógica ${ }^{361}$. Sobre o assunto, cabe destacar a posição de Fernando da Costa Tourinho Filho:

\begin{abstract}
Como ficariam os instrumentos do crime ou produtos do crime, cujo uso, porte, alienação, fabrico ou detenção constitua fato ilícito? Malgrado a falta de previsão legislativa (pois o art. 779 do CPP refere-se à medida de segurança patrimonial de que tratava o art. 110 do $\mathrm{CP}$ ), estamos que outra solução não poderá ser encontrada senão aquela apontada pelo próprio art. 779 do CPP, que continuará vigendo pelo fenômeno da repristinação. Nem teria sentido entendimento diverso. Suponha-se alguém preso em flagrante com dez quilos de cocaína. Dias depois vem ele a falecer. Obviamente, o inquérito será arquivado em face da extinção da punibilidade com fulcro no art. 107, I, do CP. Qual o destino da cocaína apreendida? Seguramente será aplicada a regra do art. 779 , do CPP. ${ }^{362}$
\end{abstract}

Parece-nos claro que, em quaisquer hipóteses (arquivamento de inquérito policial, condenação, absolvição ou impronúncia), o juiz não poderá determinar a restituição de armas ilegais, moeda falsa, documentos falsificados, substâncias entorpecentes e produtos piratas, devendo, a nosso ver, determinar a destruição (antecipada ou final) de tais coisas, resguardando apenas a quantidade ou os exemplares necessários para a produção de prova ou contraprova pericial.

Ademais, a Lei de Drogas (Lei $\left.n^{0} 11.343 / 2006\right)$ estabelece, em seu artigo $32^{363}$, que

${ }^{361}$ Em sentido contrário, Alceu Corrêa Junior defende que a medida foi extirpada do sistema: "Entretanto, a Reforma Penal realizada pela Lei 7.209/1984 alterou a sistemática da medida de segurança, reservando-a apenas aos inimputáveis e condicionando sua incidência à periculosidade do agente. Atualmente, portando, o confísco especial previsto no art. 91, II, do Código Penal caracteriza-se apenas como efeito extrapenal genérico da condenação, inexistindo a figura do confisco como medida de segurança." (CORRÊA JUNIOR, Alceu, 2006, p. 39).

362 TOURINHO FILHO, Fernando da Costa. Processo penal. 8. ed. rev. e atual., principalmente em face das Leis no 7.209/84 (Parte geral do CP) e 7.210/84 (Lei de Execução Penal). São Paulo: Saraiva, 1986. v. 3. p. 5.

363 “Art. 32. As plantações ilícitas serão imediatamente destruídas pelas autoridades de polícia judiciária, que recolherão quantidade suficiente para exame pericial, de tudo lavrando auto de levantamento das condições encontradas, com a delimitação do local, asseguradas as medidas necessárias para a preservação da prova. $\S 1^{\circ}$ A destruição de drogas far-se-á por incineração, no prazo máximo de 30 (trinta) dias, guardando-se as amostras necessárias à preservação da prova. $\S 2^{\circ} \mathrm{A}$ incineração prevista no $\S 1^{\circ}$ deste artigo será precedida de autorização judicial, ouvido o Ministério Público, e executada pela autoridade de polícia judiciária competente, na presença de representante do Ministério Público e da autoridade sanitária competente, mediante auto circunstanciado e após a perícia realizada no local da incineração. $\S 3^{\circ}$ Em caso de ser utilizada a queimada para destruir a plantação, observar-se-á, além das cautelas necessárias à proteção ao meio ambiente, o disposto no Decreto no 2.661, de 8 de julho de 1998, 
As plantações ilícitas serão imediatamente destruídas pelas autoridades de polícia judiciária, que recolherão quantidade suficiente para exame pericial, de tudo lavrando auto de levantamento das condições encontradas, com a delimitação do local, asseguradas as medidas necessárias para a preservação da prova.

Em seguida, no parágrafo $1^{\circ}$ do mesmo dispositivo, determina que a destruição de drogas será realizada no prazo máximo de 30 dias, por incineração, guardando-se as amostras necessárias à preservação da prova, sem mencionar, em nenhum dos dispositivos, eventual restituição de drogas ao respectivo possuidor.

No mesmo sentido, de incineração das drogas, o artigo 72 da mesma lei estabelece que o juiz, de ofício ou por representação, determinará a destruição de drogas de processos já encerrados ${ }^{364}$. Em suma, se a própria norma estabelece a destruição das drogas, é evidente que em nenhuma hipótese será admitida a restituição das substâncias entorpecentes a seu possuidor ou detentor.

No procedimento dos crimes contra a propriedade imaterial, o artigo $530-\mathrm{F}^{365}$ do Código de Processo Penal estabelece que, ressalvada a possibilidade de se preservar o corpo de delito, o juiz poderá, a requerimento do titular do direito de exclusivo, determinar

no que couber, dispensada a autorização prévia do órgão próprio do Sistema Nacional do Meio Ambiente - Sisnama. $\S 4^{\circ}$ As glebas cultivadas com plantações ilícitas serão expropriadas, conforme o disposto no art. 243 da Constituição Federal, de acordo com a legislação em vigor." (BRASIL. Presidência da República. Casa Civil. Subchefia para Assuntos Jurídicos. Lei $n^{o} 11.343$, de 23 de agosto de 2006. Institui o Sistema Nacional de Políticas Públicas sobre Drogas - Sisnad; prescreve medidas para prevenção do uso indevido, atenção e reinserção social de usuários e dependentes de drogas; estabelece normas para repressão à produção não autorizada e ao tráfico ilícito de drogas; define crimes e dá outras providências. Disponível em: <http://www.planalto.gov.br/ccivil_03/_ato2004-2006/2006/lei/111343.htm>. Acesso em: 21 dez. 2012).

364 "Um dos problemas comuns nos casos que envolvem entorpecentes é o armazenamento da droga apreendida. São de conhecimento público os muitos casos de desaparecimento das substâncias apreendidas, até mesmo de entorpecente que se encontrava em poder da própria polícia, ou armazenado nos depósitos judiciais. Isso decorre do fato de que a droga possui um alto valor de mercado, além de poder ser consumida por depositários em caso de apreensão. É bem verdade que casos de desaparecimento, parcial ou total, da droga apreendida são excepcionais. Mas não são somente esses os motivos que induzem à conclusão de que o entorpecente deveria, mesmo antes do final do processo, ser destruído ou inutilizado. Fatores como o risco de resgate da droga (em casos de grandes apreensões) também contribuem para o temor de extravios. Ademais, ao destruir o entorpecente, o Estado realiza um ato simbólico que influi na representação social sobre a substância (ou seja, na idéia e interpretação que a sociedade faz do assunto), e elimina a possibilidade do surgimento de dúvidas sobre a adequada custódia do entorpecente, Também soluciona problemas de espaço para o armazenamento seguro da droga (algo que envolve altos custos operacionais)." (GOMES, Luiz Flávio. Lei de drogas comentada: artigo por artigo - lei 11.343, de 23.08.2006. 3. ed. São Paulo: Revista dos Tribunais, 2008. p. 294).

365 “Art. 530-F. Ressalvada a possibilidade de se preservar o corpo de delito, o juiz poderá determinar, a requerimento da vítima, a destruição da produção ou reprodução apreendida quando não houver impugnação quanto à sua ilicitude ou quando a ação penal não puder ser iniciada por falta de determinação de quem seja o autor do ilícito." 
a destruição dos exemplares apreendidos, quando não houver impugnação quanto à sua ilicitude ou quando a ação penal não puder ser iniciada por falta de identificação dos autores do crime.

Em consonância com o dispositivo anterior, o artigo 530-G do mesmo diploma legal prevê que o juiz poderá determinar a destruição dos bens ilicitamente produzidos ou reproduzidos ${ }^{366}$ e o perdimento, em favor da Fazenda Nacional, dos equipamentos apreendidos, desde que destinados precipuamente à produção ou à reprodução de tais bens.

Portanto, da mesma forma e pelos mesmos motivos, não podemos conceber um sistema que autorize a restituição, em nenhuma hipótese, de produtos contrafeitos, ou seja, que tenham sido ilegalmente produzidos ou reproduzidos, observando que, nesses casos, apenas a fabricação, a alienação e o uso constituiriam ilícito penal em si.

Por esses motivos, a despeito da ausência da norma prevista no antigo artigo 100 do Código Penal, entendemos que não é possível a restituição, no caso de sentença condenatória, dos instrumentos do crime cujo fabrico, cujo uso, cujo porte, cuja alienação ou cuja detenção constitua fato ilícito (como arma de fogo ilegal, moeda falsa, chave falsa, documento falsificado, produto pirata, entorpecente), conforme o disposto no artigo 91, II, a, do Código Penal, e, no caso de sentença absolutória, dos instrumentos do crime referidos no artigo 91, II, a, do Código Penal, e de produtos do crime de idêntica natureza.

Segundo Tourinho Filho, o contrário “[...] seria um não-senso. Inteira aplicação haverá de ter a norma contida no art. 779, do CPP. Aplicável, será, também, nas hipóteses de impronúncia, extinção da punibilidade ou até mesmo de arquivamento de inquérito policial." 367 .

\footnotetext{
${ }^{366}$ Ficam excetuadas das hipóteses de destruição dos bens as edições de obras literárias, artísticas ou científicas, sem a autorização do titular, cujo perdimento dos exemplares apreendidos dar-se-á em favor dos autores, na forma do artigo 103 da Lei $\mathrm{n}^{\circ}$ 9.610/1998.

367 TOURINHO FILHO, Fernando da Costa, 1986, p. 5.
} 


\subsection{A apreensão satisfativa do artigo 530-B do Código de Processo Penal}

No procedimento dos crimes contra a propriedade imaterial de ação penal de iniciativa privada, como vimos, aplicam-se as normas previstas nos artigos 524 a 530-A do Código de Processo Penal. Nesse procedimento, a diligência de busca ou de apreensão será realizada por dois peritos, que verificarão se há fundamento para a apreensão e, em caso positivo, apreenderão tantos exemplares quantos forem necessários à consecução do laudo pericial, que deverá ser apresentado em três dias após a realização da diligência.

Essa medida de busca e apreensão, prevista no artigo 527 do Código de Processo Penal, tem natureza tipicamente cautelar, de meio de obtenção de provas, com o escopo de preencher o requisito de procedibilidade - previsto no artigo 525 do mesmo diploma legal — pela produção antecipada de prova pericial (i.e., para o oferecimento de queixa-crime é necessária a realização de exame de corpo de delito para comprovar a materialidade da infração).

Para tal, portanto, é necessária a diligência prévia mencionada, que, no caso, é medida cautelar que faz parte do procedimento de produção antecipada de provas, e por esse motivo, apesar de o dispositivo não identificar quantos exemplares podem ser apreendidos, já se consolidou o entendimento doutrinário e jurisprudencial de que só é lícita a apreensão de tantos exemplares quantos forem necessários à realização do exame pericial, o qual justifica a realização da medida.

Entretanto, no procedimento dos crimes contra a propriedade imaterial de ação penal de iniciativa pública, o artigo 530-B do Código de Processo Penal estabelece que a autoridade policial deve apreender todos os bens ilicitamente produzidos ou reproduzidos:

\footnotetext{
Art. 530-B. Nos casos das infrações previstas nos $\S \S 1^{\circ}, 2^{\circ}$ e $3^{\circ}$ do art. 184 do Código Penal, a autoridade policial procederá à apreensão dos bens ilicitamente produzidos ou reproduzidos, em sua totalidade, juntamente com os equipamentos, suportes e materiais que possibilitaram a sua existência, desde que estes se destinem precipuamente à prática do ilícito. (Incluído pela Lei $\mathrm{n}^{\circ}$ 10.695 , de $\left.1^{\circ} .7 .2003\right)$.
}

Essa medida, introduzida pela Lei $\mathrm{n}^{0} 10.695 / 2003$ - que tinha por escopo estabelecer novos mecanismos de combate à pirataria —, não é, sem dúvida nenhuma, uma 
medida cautelar, porque não se reveste de instrumentos destinados à preservação do próprio processo ou à eficácia e à utilidade do provimento jurisdicional.

Pelo contrário, a apreensão prevista no artigo 530-B do Código de Processo Penal tem por escopo assegurar que todos os bens ilicitamente produzidos ou reproduzidos sejam retirados daquele que sofre a medida, depositando-os com os titulares de direitos de autor e conexos, na forma do artigo 530-E do mesmo diploma legal, sem o necessário preenchimento dos requisitos das medidas cautelares.

Não existe nenhuma disposição que determine que, para o deferimento da medida de apreensão, sejam verificados os requisitos do fumus boni iuris e do periculum in mora, que, no caso, seriam a prova do direito de exclusivo (autoral e os que lhe são conexos) e a prova de que aquele que viola direitos autorais e conexos vai ocultar, alienar, inutilizar ou tomar qualquer outra medida que impeça, ao final do processo, a destruição ${ }^{368}$ dos exemplares ilicitamente produzidos ou reproduzidos ou o perdimento da edição em favor do autor ${ }^{369}$.

Logo, se a medida não pode ser classificada como cautelar, porque não visa tutelar o próprio processo ou a eficácia e a utilidade do provimento final, só podemos entender que essa medida tem natureza jurídica satisfativa, pois antecipa $a b$ initio parte do provimento final de inversão forçada da posse para a futura destruição ou perdimento dos bens ilicitamente produzidos ou reproduzidos.

Disposição semelhante foi introduzida no sistema pela Lei $n^{\circ} 9.609 / 1998$ — que dispõe sobre a proteção da propriedade intelectual de programas de computador —, cujo artigo 13 disciplinou que o juiz poderá ordenar a apreensão das cópias produzidas ou comercializadas com violação de direito de autor e das versões e derivações delas em

${ }^{368}$ Como vimos no item anterior do presente trabalho, as hipóteses de destruição antecipada estão previstas no artigo 530-F do Código de Processo Penal e a destruição no momento da sentença está prevista no artigo 530-G do mesmo diploma legal.

${ }^{369} \mathrm{O}$ artigo 102 da Lei $\mathrm{n}^{\circ}$ 9.610/1998 estabelece que em casos de obras literárias, artísticas ou científicas editadas sem a autorização do titular, quem editou perderá para o titular dos direitos de exclusivo os exemplares que se apreenderem e pagar-lhe-á o preço dos que tiver vendido. 
poder do infrator ou de quem as esteja expondo, mantendo em depósito, reproduzindo ou comercializando $^{370}$.

Aqui cumpre salientar que a medida de apreensão das cópias produzidas ou comercializadas com violação de direito de autor, bem como de suas versões e derivações, aplica-se tanto para as ações de iniciativa privada quanto para as de iniciativa pública e, em ambos os casos, a medida permite interpretação literal, que autoriza a apreensão de todas as cópias, versões e derivações de programas de computador produzidas ou comercializadas com violação ao direito de autor de software.

Em ambos os casos, no primeiro de forma mais tímida e no segundo de forma expressa, foram criadas modalidades de apreensão que não buscam a salvaguarda do próprio processo ou da eficácia do provimento jurisdicional final, com o nítido objetivo de combater a pirataria. São antecipações de tutela ou medidas satisfativas que têm por escopo retirar imediatamente de circulação os exemplares de filmes, álbuns musicais e programas de computador pirateados. É uma resposta imediata aos anseios das empresas que controlam os direitos de reprodução e distribuição de tais produtos que não pode ser justificada como uma antecipação da pena.

A maior prova de que tal legislação buscou atender interesses privados de segmentos específicos da economia é a ausência de previsão de apreensões de todos os exemplares de produtos industriais piratas, tais como roupas, calçados, brinquedos, etc., que potencialmente podem trazer danos muito maiores aos consumidores que os causados por um filme, um álbum musical ou um programa de computador piratas.

Se a legislação tivesse por escopo o bem-estar do consumidor, seguramente o principal objeto do combate à pirataria seriam os produtos industriais, cujo controle de qualidade, cuja adequação às normas de segurança e cujo respeito à não utilização de substâncias nocivas (como a utilização de tintas com chumbo em brinquedos infantis, a

${ }^{370}$ A previsão legal do artigo 13 da Lei ${ }^{\circ}{ }^{9}$.609/1998 não foi explícita como a dada pela Lei no 10.695/2003 ao artigo 530-B do Código de Processo Penal, visto que determinou apenas a apreensão das cópias, das versões e das derivações. A redação do artigo 13 da Lei $n^{\circ}$ 9.609/1998 permitiu interpretação restritiva, limitando as apreensões aos exemplares necessários à perícia, mas a redação do novo artigo 530-B do Código de Processo Penal não deixa dúvidas quanto à obrigatoriedade da apreensão de todas as cópias ilícitas. 
adequação às normas de ergonomia da indústria calçadista, etc.) só podem ser assegurados com a adequada identificação da procedência do produto.

A problemática e a nocividade da pirataria de produtos industrializados, à época da promulgação da Lei n ${ }^{0} 10.695 / 2003$, era de pleno conhecimento da Câmara dos Deputados, que desde a iniciativa de instalação da CPI da Pirataria, anterior à promulgação da Lei $\mathrm{n}^{0}$ 10.695/2003, já proclamava a dificuldade de segmentos produtivos em relação a esse assunto, conforme preâmbulo do texto do relatório final da CPI:

Esta CPI decorreu da iniciativa do Deputado Medeiros, que em boa hora ouviu os clamores dos segmentos produtivos brasileiros em risco de falência por conta da falsificação e da venda de produtos que comprometem a saúde e a segurança das pessoas, tais como bebidas, cigarros, óculos, remédios, autopeças, combustíveis e mais um sem-número de manufaturados. [...] A realidade, porém, é que a concorrência que o mercado pirata faz com o mercado legal é desleal e aviltante: sem custos de pesquisa, de desenvolvimento do produto, enfim, sem custo algum, além, é claro, da péssima qualidade do que oferece ao consumidor[...]. ${ }^{371}$

A bem da verdade, o Projeto de Lei $n^{0} 2.681 / 1996$ - que deu origem à Lei $n^{\circ}$ 10.695/2003 — de autoria conjunta do Ministério da Justiça e do Ministério da Cultura, representados pelos ministros Nelson A. Jobim e Francisco Correa Weffort, respectivamente, propunha apenas uma solução para o problema da pirataria de bens intelectuais e uma rediscussão do Projeto de Lei ${ }^{\circ}{ }^{161 / 1991}{ }^{372}$, rejeitado pela Comissão de Constituição e Justiça da Câmara dos Deputados ${ }^{373}$, sem mencionar a nova modalidade de apreensão prevista na redação proposta para o parágrafo $2^{\circ}$ do artigo 525 do Código de Processo Penal.

${ }^{371}$ BRASIL. Relatório da Comissão Parlamentar de Inquérito. Finalidade: investigar fatos relacionados à pirataria de produtos industrializados e à sonegação físcal. Presidente: deputado Medeiros. Relator: deputado Josias Quintal. Brasília, 2004. Disponível em: <http://www2.camara.leg.br/atividadelegislativa/comissoes/comissoes-temporarias/parlamentar-de-inquerito/52-

legislatura/cpipirat/relatoriofinal.pdf $>$. Acesso em: $30 \mathrm{dez} .2012$.

372 BRASIL. Projeto de Lei $n^{\circ} 161$, de 1991. Dá nova redação aos parágrafos primeiro e segundo do artigo 184 do Código Penal e estabelece normas para sua apuração e julgamento. Disponível em: $<$ http://www.camara.gov.br/proposicoesWeb/fichadetramitacao?idProposicao=172427>. Acesso em: 10 jan. 2013.

373 "No entanto, ao examinar o PL n 161/91, entendeu a Comissão de Constituição e Justiça da Câmara dos Deputados, pelo voto vencedor do Relator, que as disposições adjetivas não mereciam acolhida, eis que, 'ao estabelecer regras processuais para apuração de tais delitos, o projeto reproduz diligências já disciplinadas no Código de Processo Penal...'. Na realidade, considerou o Deputado Ibrahim Abi-Ackel que o art. $2^{\circ}$ e os $\S \S 1^{\circ}, 2^{\circ}, 3^{\circ}$ e $4^{\circ}$ do art. $3^{\circ}$ do Projeto de Lei $n^{\circ} 161 / 91$ eram desnecessários." (BRASIL. Exposição de Motivos $n^{\circ}$ 569, de 29 de outubro de 1996 dos senhores ministros de Estado da Justiça e da Cultura. Disponível em: <http://imagem.camara.gov.br/Imagem/d/pdf/DCD21FEV1997.pdf\#page=59>. Acesso em: 10 jan. 2013. 
Além disso, como se pode depreender do próprio texto da exposição de motivos do projeto de lei, as autoridades policiais já apreendiam, sem qualquer amparo legal, todas as cópias ilegais de fitas cassete com reproduções ilegais de álbuns musicais, cujo armazenamento era mantido pelo Estado, por ausência de norma que permitisse a destruição antecipada das cópias apreendidas.

\begin{abstract}
É importante consignar que a chamada pirataria de bens intelectuais está disseminada, no País, de forma assustadora. Somente em seis meses deste ano, autoridades policiais apreenderam 555.921 cassetes, contendo gravações sonoras reproduzidas sem autorização dos titulares. Como a manutenção desse material em depósito, além de complicada, é extremamente onerosa, o Código de Processo Penal passará a dispor que em não havendo impugnação quanto à ilicitude da produção ou reprodução apreendidas, o Juiz determinará sua destruição. Em caso de condenação, ao prolatar a sentença, o Juiz determinará a destruição da produção ou reprodução criminosa e determinará o perdimento dos equipamentos apreendidos em favor da Fazenda Nacional, que poderá destruí-los ou doá-los a instituições oficiais de ensino ou de assistência social $\left(\S 7^{\circ}\right)$. Por todo o exposto, Senhor Presidente, submetemos a presente proposição ao descortino de Vossa Excelência, na certeza de que, se aprovadas forem as medidas nela propostas, a denominada pirataria de bens intelectuais se reduzira sensivelmente. ${ }^{374}$
\end{abstract}

O projeto de lei teve tramitação lenta até o final de 2001, quando a deputada Laura Carneiro, com o apoio de todos os líderes de bancada, aprovou requerimento de urgência para a tramitação do projeto na Câmara dos Deputados, coincidentemente na mesma época em que as oito associações mais importantes criadas para a defesa de direitos de autor e conexos, de autor de software e de propriedade industrial iniciaram campanha conjunta contra a falsificação de discos, filmes, softwares ${ }^{375}$ e marcas famosas.

Foi da BSA a idéia de lançar a campanha, cujo lema é: Pirataria - A Vítima É sempre Você. Mas outros setores aderiram à idéia: fabricantes de roupas, calçados, brinquedos, discos, fitas de VHS e CDs, gerentes de licenciamentos, distribuidores de sinal de TV paga, fabricantes nacionais de softwares. A união deles todos é o primeiro esforço interindustrial feito no Brasil, para combater a venda de produtos falsificados - ou melhor, para tentar alertar o consumidor e sensibilizar as autoridades com a gravidade do problema. [...] As oito entidades que encabeçam a campanha anti-pirataria são a Abes (software), Abral (licenciamento), Abravest (vestuário), Abrinq (brinquedos), ABTA (telecomunicações por assinatura), ABPD (discos), BSA (internacional de

374 BRASIL. Projeto de Lei $n^{o}$ 2.681, de 1996 (do Poder Executivo). Mensagem no 1.349/96. Dá nova redação aos $\S \S 1^{\circ}$ e $3^{\circ}$ do art. 184 e ao art. 186 do Decreto-Lei $n^{\circ} 2.848$, de 7 de dezembro de 1940 Código Penal, e acrescenta parágrafos ao art. 525 do Decreto-Lei $n^{\circ} 3.689$, de 3 de outubro de 1941 Código de Processo Penal. Disponível em: <http://imagem.camara.gov.br/Imagem/d/pdf/ DCD21FEV1997.pdf\#page=59>. Acesso em: 10 jan. 2013.

375 "Nos primeiros dois meses do ano, a Abes e a BSA realizaram 38 ações de rua, que resultaram na apreensão de mais de 147 mil cópias ilegais de programas - equivalente a $41 \%$ do total de CDs apreendidos em 2002. Além disso, foram instaurados 33 processos judiciais contra empresas que foram flagradas utilizando software pirata". (CAMPANHA liga pirataria ao crime organizado. O Estado de São Paulo Online, São Paulo, 16 abr. 2003. Tecnologia. Disponível em: <http://www.estadao.com.br/ arquivo/tecnologia/2003/not20030416p44544.htm>. Acesso em: 10 jan. 2013). 
software), e MPA (cinema). Na avaliação de seus representantes, os grandes piratas modernos são as máfias chinesas. Eles acreditam que, com a pouca repressão à pirataria de marcas e criação intelectual nos países do Terceiro Mundo e o grande lucro que vem da atividade criminosa, as máfias do tráfico de drogas migrem para a pirataria de idéias. Menos combatida, seria mais segura. ${ }^{376}$

Em seguida, foi aprovado o relatório da Comissão de Constituição e Justiça da Câmara dos Deputados, diante da pressão maciça das empresas do setor, e o projeto de lei teve tramitação rápida nas duas casas legislativas, sendo convertido, em menos de seis meses, na Lei $n^{0} 10.695 / 2003$, que modificou o Código Penal e o Código de Processo Penal com o objetivo declarado de combater a pirataria de bens intelectuais.

Talvez pelo fato de ser de iniciativa do Ministério da Cultura, talvez pela falta de discussão e pela aprovação em regime de urgência para dar uma resposta legislativa às pressões da indústria fonográfica e cinematográfica, o projeto trouxe distorções ao sistema de proteção, estabelecendo tratamento desigual a direitos equivalentes de propriedade imaterial. Entretanto, a reforma trouxe, sem nenhum destaque, uma medida que, apesar de importante para o procedimento dos crimes contra a propriedade imaterial e para o combate à pirataria, foi pouco discutida: a apreensão de todos os bens ilicitamente produzidos ou reproduzidos.

A nova medida ficou ofuscada pela significativa alteração no artigo 184 do Código Penal e pela reforma do procedimento dos crimes contra a propriedade imaterial, com a introdução de um novo procedimento para os crimes de ação penal de iniciativa pública. Ademais, a medida não teve qualquer destaque porque, antes da promulgação da referida norma, já era prática corrente nas ações de combate à pirataria a apreensão de todas as cópias ilícitas, sem previsão legal que permitisse essa modalidade de apreensão.

Mas, como veremos a seguir, apesar de essa nova modalidade de apreensão ser um instrumento valioso para garantir a eficiência do procedimento dos crimes contra a propriedade imaterial, não foi contemplada na proposta de reforma do Código de Processo Penal que atualmente tramita no Congresso Nacional.

${ }^{376}$ CAMPANHA combate pirataria intelectual. O Estado de São Paulo Online, São Paulo, 19 mar. 2002. Caderno2. Disponível em: <http://www.estadao.com.br/arquivo/arteelazer/2002/not20020319p3288.htm> Acesso em: 10 jan. 2013. 


\subsubsection{A APREensão PReVista No ARTigo 530-B do CPP, o PLS N ${ }^{\circ} 156 / 2009$ E o PL N ${ }^{0}$ $2.729 / 2003$}

Em 2008 foi criada a comissão de juristas responsável pela elaboração do anteprojeto de reforma do Código de Processo Penal no Senado Federal, formada pelos eminentes juristas Antonio Correa, Antonio Magalhães Gomes Filho, Eugênio Pacelli de Oliveira, Fabiano Augusto Martins Silveira, Felix Valois Coelho Júnior, Hamilton Carvalhido, Jacinto Nelson de Miranda Coutinho, Sandro Torres Avelar e Tito Souza do Amaral.

A comissão elaborou o texto básico do anteprojeto de reforma do Código de Processo Penal, que foi convertido no Projeto de Lei do Senado $n^{0} 156$, de $2009^{377}$, e atualmente ainda está em tramitação legislativa no Congresso Nacional.

No referido projeto, foram extirpados todos os procedimentos especiais atualmente existentes no Código de Processo Penal - inclusive o procedimento dos crimes contra a propriedade imaterial - , exceto os processos de competência do Tribunal do Júri e os processos de competência originária dos tribunais, conforme o disposto no artigo 257 do PLS 156/2009: “Art. 257. O procedimento será comum ou especial, aplicável ao Tribunal do Júri e nos tribunais.”.

Apesar de concordarmos que não é imperiosa a manutenção de um procedimento especial para os crimes contra a propriedade imaterial, devemos ressaltar que a necessidade de comprovação, no momento do pedido de busca e apreensão, dos direitos de exclusivo (patente de invenção ou de modelo de utilidade concedida, registro de desenho industrial, registro de programa de computador ou de autoria de obra literária, artística ou científica) evita a propositura de ações ilegítimas.

Outro ponto a ser observado é que o artigo 46 do texto original do projeto de lei estabelece que a ação penal nos crimes contra o patrimônio imaterial, quando dirigida exclusivamente contra bens jurídicos do particular ${ }^{378}$, será de natureza pública

\footnotetext{
377 BRASIL. Senado. Comissão de juristas responsável pela elaboração de anteprojeto de reforma do Código de Processo Penal. Anteprojeto. Brasília: Senado Federal, 2009. Disponível em: $<\mathrm{http}$ ://www6.senado.gov.br/mate-pdf/58503.pdf>. Acesso em: 23 dez. 2012.

378 A adoção da expressão "quando dirigidas exclusivamente contra bens jurídicos do particular" trará dúvidas sobre a necessidade de representação nos casos dos crimes previstos no artigo $12, \S 3^{\circ}$, II, que
} 
condicionada à representação da vítima. Isso seguramente trará um problema de ordem prática, consistente na identificação e na intimação de todos os titulares de produtos apreendidos nos casos de pirataria, visto que as apreensões normalmente atingem centenas de títulos de filmes, álbuns musicais e programas de computador com titulares distintos.

Em relação às coisas que não podem ser restituídas, o projeto de lei resolve o problema em parte, ao determinar, em seu artigo 435, que as coisas referidas no inciso II do artigo 91 do Código Penal “[...] não poderão ser restituídas, mesmo depois de transitar em julgado a sentença final, salvo se pertencerem ao lesado ou a terceiro de boa-fé.".

Por fim, cumpre destacar que o artigo 221 do PLS 156/2009 379 prevê que a diligência de busca domiciliar pode ser determinada quando houver indícios suficientes de que pessoa que deva ser presa ou objetos que possam servir de prova de infração penal encontrem-se em local não livremente acessível ao público.

A condição estabelecida pelo referido dispositivo, de que podem ser apreendidos os objetos que possam servir de prova da infração penal, não permite outra interpretação senão a de que só podem ser apreendidos os objetos necessários para a produção da prova, o que impediria a apreensão da totalidade dos bens ilicitamente produzidos ou reproduzidos, prevista no artigo 530-B do Código de Processo Penal.

Somado a isso, a posição topográfica das medidas de busca e de apreensão, que foram tratadas em conjunto no capítulo III ("Dos meios de obtenção da prova") do título VII ("Da prova”) do PLS n ${ }^{\circ} 156 / 2009$, não deixa dúvidas de que a comissão não previu e não queria prever nenhuma medida de apreensão com caráter satisfativo como a prevista no artigo 530-B do Código de Processo Penal.

Ao retirar do sistema a apreensão da totalidade dos bens ilicitamente produzidos ou reproduzidos, o projeto do novo código de processo penal excluirá uma das medidas mais eficazes no combate à pirataria, reduzindo a abrangência das medidas mencionadas no

determina que a ação será de iniciativa pública incondicionada quando, “[...] em decorrência de ato delituoso, resultar sonegação físcal, perda de arrecadação tributária ou prática de quaisquer dos crimes contra a ordem tributária ou contra as relações de consumo."

379 “Art. 221. Proceder-se-á à busca domiciliar, quando houver indícios suficientes de que pessoa que deva ser presa ou objetos que possam servir de prova de infração penal encontrem-se em local não livremente acessível ao público.” 
artigo 61 do Acordo Sobre Aspectos dos Direitos de Propriedade Intelectual Relacionados ao Comércio (TRIPs) de 1994:

Artigo 61. Os Membros proverão a aplicação de procedimentos penais e penalidades pelo menos nos casos de contrafação voluntária de marcas e pirataria em escala comercial. Os remédios disponíveis incluirão prisão e/ou multas monetárias suficientes para constituir um fator de dissuasão, de forma compatível com o nível de penalidades aplicadas a crimes de gravidade correspondente. Em casos apropriados, os remédios disponíveis também incluirão a apreensão, perda e destruição dos bens que violem direitos de propriedade intelectual e de quaisquer materiais e implementos cujo uso predominante tenha sido na consecução do delito. Os Membros podem prover a aplicação de procedimentos penais e penalidades em outros casos de violação de direitos de propriedade intelectual, em especial quando eles forem cometidos voluntariamente e em escala comercial. ${ }^{380}$

Paralelamente ao PLS $n^{0} 156 / 2009$, também estava em tramitação no Congresso Nacional o Projeto de Lei $n^{\circ} 8.052 / 2011$, de iniciativa do Conselho Nacional de Combate à Pirataria e Delitos contra a Propriedade Intelectual, que visa modificar os artigos 530-C, 530-D, 530-F e 530-G no Código de Processo Penal, “[...] com o propósito de tornar mais céleres o processo e julgamento dos crimes cometidos contra propriedade imaterial (violação de direito autoral - art. 184 do Código Penal)."381.

O projeto de lei trazia pequenas modificações no sistema, que explicitam a natureza satisfativa da medida, sendo elas: 1) propõe que o auto de apreensão descreva as coisas apreendidas por lotes, com a justificativa de que nas grandes apreensões de produtos piratas é impossível descrever detalhadamente todos os bens apreendidos; 2) propõe que o laudo seja elaborado sobre amostras e não sobre a totalidade dos bens apreendidos; 3) obriga o juiz a determinar a destruição quando não houver impugnação sobre a ilicitude dos bens apreendidos ou quando a ação não puder ser iniciada por falta de elementos para a identificação dos autores do ilícito; 4) obriga o juiz a determinar a destruição dos bens ilicitamente produzidos ou reproduzidos, tanto nos casos de condenação quanto nos casos de absolvição.

${ }^{380}$ BRASIL. Acordo Sobre Aspectos dos Direitos de Propriedade Intelectual Relacionados ao Comércio (Acordo TRIPS ou Acordo ADPIC). Brasília, 1994. Disponível em: <http://www.cultura.gov.br/site/wpcontent/uploads/2008/02/ac_trips.pdf $>$. Acesso em 24 dez. 2012.

381 BRASIL. Projeto de Lei $\overline{n^{\circ}}$ 8.052/2011. Brasília, 2011. Disponível em: <http://www.camara.gov.br/ proposicoesWeb/prop_mostrarintegra?codteor $=832354 \&$ filename=Tramitacao-PL $+8052 / 2011>$. Acesso em: 11 jan. 2013. 
Entretanto, o projeto de lei foi apensado ao Projeto de Lei $n^{0} 2.729 / 2003^{382}$, de autoria do deputado federal Leonardo Picciani, que tinha escopo muito mais abrangente, vez que pretendia alterar todo o sistema, igualando a pirataria de produtos industriais aos casos de pirataria de obras autorais e programas de computador e modificando as penas dos crimes contra a propriedade imaterial e a respectiva iniciativa da ação penal.

O apensamento teve como objeto unificar todas as propostas existentes na Câmara dos Deputados, sendo aprovada a redação final assinada pelo relator da Comissão de Constituição e Justiça e de Cidadania da Câmara dos Deputados, deputado Guilherme Campos, que extirpou todas as propostas de modificação global do sistema, restringindo o projeto ao proposto pelo Conselho Nacional de Combate à Pirataria e Delitos contra a Propriedade Intelectual, com exceção da hipótese de destruição nos casos de sentença absolutória, que pelo próprio sistema era desnecessária.

A existência de dois projetos de lei concomitantes no Congresso Nacional - o primeiro retirando a apreensão prevista no artigo 530-B do Código de Processo Penal do sistema e o segundo ressaltando a natureza jurídica satisfativa da medida - nos leva aos seguintes questionamentos: 1) a apreensão prevista no artigo 530-B do Código de Processo Penal viola o princípio da presunção de inocência?; 2) se a apreensão prevista no artigo 530-B do Código de Processo Penal não viola o princípio da presunção de inocência, a medida é eficiente para os fins propostos e no seu procedimento estão asseguradas as garantias individuais aos imputados?

\subsubsection{A apreensão prevista no artigo 530-B do Código de Processo Penal e o PRINCÍPIO DA PRESUNÇÃO DE INOCÊNCIA}

Para verificarmos se a apreensão prevista no artigo 530-B do Código de Processo Penal viola o princípio da presunção de inocência, faremos uma resumida análise do conteúdo e da extensão do referido princípio no ordenamento jurídico brasileiro, verificando a forma de proteção e as implicações para a disciplina da apreensão.

382 BRASIL. Projeto de Lei $n^{o}$ 2.729/2003. Brasília, 2003. Disponível em: <http://www.camara.gov.br/ proposicoesWeb/fichadetramitacao?idProposicao=148171>. Acesso em: 11 jan. 2013. 
Nos modernos textos constitucionais e nas declarações internacionais de direitos humanos do pós-guerra, o princípio da presunção de inocência vem descrito de duas formas: a primeira em termos de presunção e a segunda como status do acusado durante o processo (estado de inocência ou de não culpabilidade do acusado) ${ }^{383}$.

$\mathrm{Na}$ forma de presunção, o princípio refere-se principalmente à disciplina probatória, enquanto na forma de status do acusado (estado de inocência ou não culpabilidade), referese ao tratamento do acusado, vedando quaisquer medidas que impliquem a sua equiparação ao culpado. Entretanto, independentemente da enunciação, não podemos limitar o conteúdo do princípio a umas dessas duas fórmulas, pois o princípio da presunção de inocência abrange os dois significados: regra de tratamento do imputado e regra probatória.

No Brasil, antes da recepção do Pacto de São José da Costa Rica ${ }^{384}$, existia certa resistência ao princípio, fazendo valer o discurso repressivo de que a Constituição Federal de 1988 enunciava apenas o status de não culpabilidade do acusado, uma vez que o artigo $5^{\circ}$, LVII, estabeleceu que “[...] ninguém será considerado culpado até o trânsito em julgado da sentença penal condenatória.”.

Entretanto, a interpretação restritiva do princípio da presunção de inocência perdeu sua justificação pela recepção — com força de regra constitucional ${ }^{385}$ — do artigo 8.1 da Convenção Americana sobre Direitos Humanos (Pacto de São José da Costa Rica), por meio do Decreto $\mathrm{n}^{\mathrm{o}} 678$, de 2 de novembro de $1992^{386}$, que determina que "[...] toda pessoa acusada de delito tem direito a que se presuma sua inocência enquanto não se comprove legalmente sua culpa.”.

${ }^{383}$ Cf. GOMES FILHO, Antonio. O princípio da presunção de inocência na constituição de 1988 e na convenção americana sobre direitos humanos (pacto de São José da Costa Rica). Revista do Advogado, São Paulo, n. 42, p. 30-34, 1994. p. 31.

${ }^{384}$ BRASIL. Ministério das Relações Exteriores. Anexo ao Decreto que Promulga a Convenção Americana sobre Direitos Humanos (Pacto de São José da Costa Rica). Brasília, 1992. Disponível em: $<$ http://www.planalto.gov.br/ccivil_03/decreto/1990-1994/anexo/and678-92.pdf $>$. Acesso em: 22 dez. 2012.

${ }^{385} \mathrm{O}$ artigo $5^{\circ}, \S 2^{\circ}$, da Constituição de 1988 determina que os direitos e as garantias expressos na Constituição não excluem outros decorrentes dos tratados internacionais em que a República Federativa do Brasil seja parte, recepcionando, portanto, com força de regras constitucionais, as normas do pacto de São José da Costa Rica que versam sobre direitos e garantias individuais.

${ }^{386}$ BRASIL. Decreto $n^{\circ}$ 678, de 6 de novembro de 1992. Promulga a Convenção Americana sobre Direitos Humanos (Pacto de São José da Costa Rica), de 22 de novembro de 1969. Disponível em: $<$ http://www.planalto.gov.br/ccivil_03/decreto/D0678.htm>. Acesso em: 22 dez. 2012. 
Uma vez que o ordenamento jurídico brasileiro contempla ambas as enunciações do princípio, não é possível que sobre este seja feita qualquer restrição interpretativa, devendo prevalecer como norma probatória e como norma de tratamento.

Do princípio da presunção de inocência como norma probatória decorrem as regras de ônus da prova, as regras sobre a licitude da prova e as regras sobre o objeto da prova. As primeiras impõem que ao acusado não se pode impor qualquer ônus probatório mesmo para circunstâncias atenuantes, causas de diminuição de pena, excludentes de ilicitude ou de culpabilidade —, uma vez que o ônus de provar, no processo penal, é sempre da acusação e não pode ser suprido por presunções.

\begin{abstract}
Quanto ao interesse do acusado na atividade probatória, é inegável que ele se guia sempre na busca de provas da sua inocência. Não há, porém, o dever de produzir prova de sua inocência. $O$ acusado tem no processo um interesse unilateral de buscar a solução que lhe seja mais favorável, razão pela qual sua atividade pode ser regida e estimulada através dos ônus processuais. Especificamente no campo instrutório, a atividade probatória do acusado pode ser realizada como conseqüência da imposição do onus probandi. [...] Contudo, já antecipando uma das conclusões, o princípio do in dubio pro reo impede que se imponha ao acusado qualquer ônus probatório na ação penal condenatória, mesmo em relação às excludentes de ilicitude e de culpabilidade. ${ }^{387}$
\end{abstract}

As regras de licitude, por sua vez, determinam que nenhum elemento de prova obtido de modo ilícito seja introduzido no processo, e, se o for, deverá ser desentranhado, para que não possa influenciar ou servir de fundamentação para a decisão judicial ${ }^{388}$. A positivação da inadmissibilidade da utilização de provas ilícitas contra o acusado encontrase no texto do Pacto de São José da Costa Rica, que dispõe que a inocência deve ser presumida enquanto não se comprove legalmente a culpa.

Por fim, as regras sobre o objeto da prova determinam que o processo deve sempre buscar a comprovação dos fatos imputados ao acusado, pois não se presta a verificar a verossimilhança das alegações defensivas. $\mathrm{O}$ acusado não é mais o objeto do processo; o objeto do processo é composto pelos fatos e pelas circunstâncias cujo cometimento é a ele imputado $^{389}$.

${ }^{387}$ BADARÓ, Gustavo Henrique Righi Ivahy. Ônus da prova no direito processual penal brasileiro. 2002. 488 f. Tese (Doutorado em Direito)- Faculdade de Direito, Universidade de São Paulo, São Paulo, 2002. p. 223-225.

388 Cf. ZANOIDE DE MORAES, Maurício. Presunção de inocência no processo penal brasileiro: análise de sua estrutura normativa para a elaboração legislativa e para a decisão judicial. Rio de Janeiro: Lumen Juris, 2010. p. 465.

${ }^{389}$ Cf. GOMES FILHO, Antonio Magalhães, 1994, p. 31. 
Do princípio da presunção de inocência como norma de tratamento decorre a preservação da dignidade do acusado em todos os atos do procedimento, sem o expor a situações degradantes ou que demonstrem um prejulgamento, e restringindo as medidas cautelares àquelas efetivamente necessárias, adequadas e proporcionais.

Isso significa que, durante o processo, não podem ser utilizados termos que exprimam antecipações do juízo condenatório, o acusado não pode ser colocado em situações que o equiparem ao condenado, tais como o uso de algemas durante as audiências $^{390}$, e não podem ser impostas, antes da condenação definitiva, quaisquer medidas restritivas de liberdade que não estejam fundadas em seus requisitos cautelares (fumus boni iuris e periculum in mora).

Em suma, a presunção de inocência como norma de tratamento pressupõe que os atos processuais respeitem o status de inocência do acusado, impedindo qualquer medida restritiva de direitos fundamentais que represente um juízo antecipado da condenação.

Na cultura da Civil Law, a forma mais tradicional de se compreender a
presunção de inocência é considerá-la como uma garantia de que o cidadão será
tratado na persecução penal como inocente. Isto é, garante-se que os efeitos de
uma eventual decisão condenatória somente sejam aplicados após o seu trânsito
em julgado. Nessa linha, violam a presunção de inocência como "norma de
tratamento" todos os dispositivos legais que, de forma absoluta e apriorística,
imponham antecipação de qualquer espécie de sanção que, prima facie, somente
adviria por força de decisão condenatória definitiva.

Partindo do pressuposto de que o processo é o meio necessário para a cognição dos fatos imputados - por meio da produção da prova em juízo, a qual permite a confirmação da existência de crime e da autoria —, nenhum crime pode ser considerado cometido e nenhum acusado pode ser considerado culpado, nem submetido a uma pena antecipada, até o trânsito em julgado da sentença condenatória, em respeito ao princípio da presunção de inocência.

Assim, se o acusado deve, pela referida norma, ter o seu estado de inocência respeitado, não poderia ser tomada contra ele nenhuma medida que importasse a restrição de quaisquer de suas liberdades até a prolação de uma sentença definitiva. Entretanto, o 
processo demanda tempo, e por esse motivo são necessárias algumas medidas que protejam o próprio processo e a eficácia do provimento jurisdicional.

Como dissemos, durante esse período de desenvolvimento das atividades que permitem, em decorrência da dialética do contraditório, a cognição dos fatos, podem ser necessárias medidas cautelares, que protejam a realização do processo e a eficácia do provimento final. Entretanto, devem ser evitadas as medidas que se mostrem antecipatórias, uma vez que medidas cautelares, como a prisão preventiva, foram aplicadas durante muitos anos como medidas de segurança social, prevenindo a criminalidade pelo encarceramento antecipado dos acusado ou pela execução antecipada da pena ${ }^{392}$.

Com a recepção do princípio da presunção de inocência como norma de tratamento não podemos admitir, portanto, em hipótese alguma, que contra o acusado sejam aplicadas medidas travestidas de cautelares que sejam, na verdade, medidas de segurança social, que antecipem os efeitos da sentença condenatória.

A medida de busca e apreensão no procedimento dos crimes contra a propriedade imaterial de ação de iniciativa privada é uma medida tipicamente cautelar, porque é estabelecida na forma de produção antecipada de provas e tem por escopo determinar, como requisito de procedibilidade para uma eventual e futura ação penal, a efetiva existência de materialidade do crime.

Por ter característica marcadamente instrumental, por meio dela só se permite a apreensão de tantos exemplares quantos forem necessários para a produção da prova pericial, que comprovará ou não a materialidade delitiva - a saber, a existência ou não de atos de contrafação de produto ou processo protegido pelo direito de exclusivo - , i.e., a apreensão protege tanto o processo quanto o demandado, assegurando que nenhuma medida judicial será aceita sem a prova da materialidade delitiva.

A apreensão prevista no artigo 530-B do Código de Processo Penal, por sua vez, não é medida tipicamente cautelar, porque permite a apreensão de todos os exemplares ilegalmente produzidos ou reproduzidos, servindo apenas algumas unidades como corpo de

\footnotetext{
392 Cf. FERRAJOLI, Luigi, 2000, p. 553.
} 
delito necessário à produção da prova pericial. Por esse motivo não é possível classificar a medida como cautelar, tendo em vista sua natureza tipicamente antecipatória ou satisfativa.

Entretanto, ela não antecipa um juízo de condenação ou efeitos decorrentes exclusivamente da sentença condenatória, pois, como já dissemos no item 5.2 do presente trabalho, a antecipação refere-se às coisas que não podem ser restituídas, e por esse motivo, antecipa um capítulo distinto da sentença, seja ela condenatória, seja absolutória.

\begin{abstract}
A configuração dos capítulos de sentença segundo o modo-de-ser do direito brasileiro corresponde substancialmente à que fora proposta por Enrico Tullio Liebman em seu famoso ensaio. Cada capítulo do decisório, quer todos de mérito, quer heterogêneos, é uma unidade elementar autônoma, no sentido de que cada um deles expressa uma deliberação específica; cada uma dessas deliberações é distinta das contidas nos demais capítulos e resulta da verificação de pressupostos próprios, que não se confundem com os pressupostos das outras. $^{393}$
\end{abstract}

Não é o juízo de culpabilidade da sentença condenatória ou da sentença absolutória que determinará se os bens sujeitos à apreensão prevista no artigo 530-B do Código de Processo Penal serão passíveis de restituição; é a própria qualidade dos bens e o resultado da prova pericial que determinarão a ilegalidade da produção ou da reprodução, que independe da prova de autoria ou culpabilidade do acusado.

Portanto, refere-se a capítulo da sentença distinto do que trata da autoria e da culpabilidade do acusado e, por esse motivo, sua antecipação não implica a supressão do princípio da presunção de inocência insculpido no artigo $5^{\circ}$, LVII, da Constituição Federal, porque tanto em casos de sentença condenatória quanto em casos de sentença absolutória as coisas apreendidas não poderão ser restituídas àqueles que as detinham ou retinham quando a fabricação, a venda, o uso, o porte ou a detenção constitua ilícito autônomo.

Assim, se a apreensão introduzida no sistema pelo artigo 530-B do Código de Processo Penal não viola o princípio constitucional da presunção de inocência, passaremos a avaliar a eficiência da medida aos fins propostos e a existência de garantias adequadas ao imputado no procedimento previsto.

393 DINAMARCO, Cândido Rangel. Capítulos de sentença. 4. ed., São Paulo: Malheiros, 2009, p. 37. 


\subsubsection{A apreensão prevista no artigo 530-B do Código de Processo Penal: EFICIÊNCIA E GARANTISMO}

A medida de apreensão prevista no artigo 530-B do Código de Processo Penal foi introduzida no sistema processual penal brasileiro no bojo da reforma de 2003, que tinha como objetivo criar mecanismos eficientes de combate à pirataria. Entretanto, na reforma desperdiçou-se a oportunidade de organizar o sistema de proteção penal da propriedade intelectual, que permanece fragmentado por normas que disciplinam de forma desigual a proteção de direitos assemelhados.

Primeiro, perdeu-se a oportunidade de criar um novo tipo penal específico para o combate à pirataria aproveitando o conceito de contrafação para separar a pirataria (reprodução servil) das demais espécies de contrafação; segundo, perdeu-se a oportunidade de separar as contrafações dos demais tipos penais, em especial das violações de direitos morais de autor e da concorrência desleal; terceiro, deixou-se de criar tipos penais que abrangessem as três espécies de propriedade imaterial - direito de autor, direito de autor de software e propriedade industrial —, o que unificaria a proteção penal.

Enfim, a reforma passou longe da melhor técnica legislativa penal e processual penal, introduzindo modificações no sistema que visavam proteger essencialmente as empresas fonográficas e cinematográficas, deixando de fora as empresa de software, já protegidas pela Lei $\mathrm{n}^{0}$ 9.609/1998, e a atividade industrial, que ficou sem proteção específica contra a pirataria.

Quando pensamos em pirataria no Brasil, a primeira imagem de que nos lembramos são as campanhas da União Brasileira de Vídeo e da Agência Nacional de Cinema, que equiparavam a figura do camelô que vende filmes piratas à do traficante de drogas e de armas, ou as campanhas da Associação Brasileira das Empresas de Software (ABES) e da Business Software Alliance (BSA) contra a pirataria de programas de computador, mas a pirataria não se restringe a essa gama de produtos.

São inúmeros os produtos pirateados disponíveis no mercado brasileiro, como brinquedos, roupas, bolsas e acessórios, relógios, produtos eletrônicos, telefones celulares, produtos de higiene e beleza, programas de computador, etc. Tais produtos também são 
objeto de contrafação por cópia vil, que podem, pela falta de adequada identificação e controle de procedência do produto, ser mais nocivos que os vídeos piratas.

As principais críticas sobre a reforma de 2003, sem dúvida alguma, são a falta de sistematização da proteção penal da propriedade intelectual e a ausência de um procedimento processual penal justo.

\begin{abstract}
O direito ao procedimento processual penal é, em síntese, direito a um sistema de regras e princípios que permita a atuação eficaz dos órgãos encarregados da persecução penal e que, ao mesmo tempo, assegure a plena efetivação das garantias do devido processo penal. O direito a um sistema de regras e princípios que conjuguem eficiência e garantia não representa direito a um procedimento certo, com todos os seus atos e fases em seqüência predeterminada, mas o direito a um procedimento assentado em alguns paradigmas extraídos de normas constitucionais do devido processo penal. ${ }^{394}$
\end{abstract}

Nessa esteira, poderia ter sido criado um tipo penal específico para a pirataria, englobando as condutas de contrafação por cópia vil de produtos industriais, programas de computador e obras literárias, artísticas, científicas, musicais, cinematográficas e assemelhadas, separando-as das demais condutas vedadas.

As demais formas de contrafação, a concorrência desleal e a violação de direitos morais de autor poderiam compor outros tipos penais, sujeitos ao procedimento da ação de iniciativa privada, mantendo a busca e a apreensão como medida tipicamente cautelar, de produção antecipada de provas.

Para os crimes de pirataria, a ação penal seria de iniciativa pública, mantendo-se a apreensão satisfativa como medida de eficiência do procedimento, uma vez que, independentemente do resultado do processo (condenação ou absolvição) ou do inquérito policial (arquivamento), as coisas apreendidas não poderão ser devolvidas, visto que constituem em si mesmas um ilícito penal autônomo (exceto nos casos de cópia única para uso privado do copista nos quais não haja intuito de lucro).

Apesar de não termos identificado no decorrer desta pesquisa nenhum trabalho nesse sentido, as apreensões de grandes quantidades de armas de fogo ilegais, moedas

${ }^{394}$ FERNANDES, Antonio Scarance. Reflexões sobre as nações de eficiência e de garantismo no processo penal. In: FERNANDES, Antonio Scarance; ALMEIDA, José Raul Gavião de; MORAIS, Maurício Zanoide de. (Orgs.). Sigilo no processo penal, eficiência e garantismo. São Paulo: Revista dos Tribunais, 2008. p. 9-28. p. 13. 
falsas e entorpecentes também não se justificam como medidas tipicamente cautelares, cujo apossamento se destina única e exclusivamente à produção de prova pericial. Trata-se, na verdade, de medidas satisfativas que têm como principal escopo antecipar um capítulo específico da sentença ou da decisão de arquivamento e que são tomadas em relação a coisas que não podem ser restituídas porque sua posse ou detenção configuram por si só conduta ilícita autônoma.

Por esse motivo, é preferível aceitar a existência de medidas de antecipação do provimento final no processo penal que não importem em uma antecipação do juízo condenatório (de autoria e culpabilidade) por serem afetas a outro capítulo da sentença (das coisas que não podem ser restituídas) e assegurar, por outro lado, um procedimento que observe as garantias constitucionais do imputado.

A Lei de Drogas, nesse sentido, assegurou, no parágrafo $1^{\circ}$ do artigo 50 , que o próprio perito, ou pessoa idônea, constatará a natureza e a quantidade de droga apreendida, impondo ao procedimento um ato de constatação para impedir demandas judiciais pautadas em apreensões de substâncias que não são vedadas pela Lei de Drogas.

Da mesma forma, poderia existir, no procedimento dos crimes contra a propriedade imaterial de ação de iniciativa pública, um ato de constatação da ilicitude das cópias apreendidas, pois, diferentemente do previsto no procedimento dos crimes de ação penal de iniciativa privada, o procedimento prescrito não determina, para os de ação penal de iniciativa pública, o prazo de três dias para a confecção do laudo pericial.

Afinal, apesar de as contrafações de filmes, álbuns musicais e programas de computador serem visualmente identificáveis, as contrafações de produtos de luxo, hoje, empregam materiais absolutamente parecidos com os originais e alcançam tal grau de perfeição que mesmo os peritos encontram dificuldades em separar os originais das cópias; por esse motivo, é necessário que o procedimento preveja a elaboração de um auto de constatação, por perito ou pessoa tecnicamente habilitada, assegurando a ilicitude das cópias apreendidas.

Por isso, entendemos que a exigência de elaboração de um auto de constatação, prevista no procedimento da Lei de Drogas (art. 50, $\S 1^{\circ}$ ), deveria ser aplicada, por 
analogia, aos casos de apreensão de produtos contrafeitos sujeitos ao procedimento dos crimes contra a propriedade imaterial de ação penal de iniciativa pública, assegurando um ato de verificação para aumentar a probabilidade de acerto do provimento jurisdicional antecipatório ou satisfativo.

Além disso, por se tratar de medida que antecipa parte do provimento jurisdicional final, entendemos que seria imprescindível que, logo após a apreensão, a autoridade policial remetesse cópia do auto de apreensão e do respectivo auto de constatação ao juiz, para que, após a manifestação do Ministério Público, fosse convalidada a apreensão ou, se fosse o caso, determinada a restituição das cópias apreendidas a quem as possuía ou detinha no momento da apreensão.

Pois, como vimos, as apreensões no procedimento dos crimes contra a propriedade imaterial de ação penal de iniciativa pública podem ser decorrentes da busca profícua - e, portanto, estarão amparadas por ordem judicial — ou podem ser decorrentes do encontro casual, em lugares públicos ou lugares privados abertos ao público, dos objetos contrafeitos - e, nesses casos, não serão precedidas de ordem judicial ${ }^{395}$.

Dessa forma, asseguraríamos um procedimento processual penal eficiente e garantista, aparelhado com uma medida de apreensão de todos os objetos pirateados, garantindo, de um lado, o pleno exercício dos direitos de defesa e, de outro, medidas eficientes no combate à pirataria.

395 Consideramos que as hipóteses de apreensão decorrentes do encontro casual, em lugares públicos ou lugares privados abertos ao público, abrangem tanto os casos de prisão em flagrante, quanto os casos de apreensão de coisas achadas. 


\section{CONCLUSÕES}

$1.1 \mathrm{O}$ direito industrial e os direitos autorais no Brasil tiveram origens muito distintas, entretanto ambos foram incorporados ao nosso ordenamento jurídico como mecanismos de controle da coroa sobre a colônia. Da mesma forma que a atividade industrial era proibida pela coroa portuguesa como modo de evitar qualquer atividade que se sobrepusesse às atividades extrativistas das riquezas naturais, era igualmente proibida a instalação de tipografias no Brasil, como forma de controle e censura prévia dos escritos.

Com a vinda do trono português para o Brasil, em 1808, tornou-se necessária a instalação da Imprensa Régia na colônia, mantendo-se o monopólio de impressão e a censura prévia, que perduraram até a promulgação da Constituição portuguesa de 1822 . No ano seguinte ao da instalação da Imprensa Régia, foi promulgado o primeiro regramento de patentes de invenção para a indústria brasileira, como forma de incentivar uma atividade que mal existia, visto que era proibida pela legislação anterior.

1.2 Apesar de terem origens distintas, o direito industrial e o direito autoral fazem parte de um gênero chamado "propriedade intelectual", que pode ser dividido em duas categorias principais, a das criações (pertencentes ao respectivo criador), que se subdividem em direitos de autor, programas de computador, cultivares e invenções industriais, e a dos sinais distintivos (pertencentes às empresas), que se subdividem em nomes empresariais e marcas.

Os direitos autorais estão disciplinados na Lei $n^{0} 9.610 / 1998$, por meio de um sistema unitário de tratamento do direito de autor e dos direitos conexos, abrangendo tanto os direitos sobre as obras literárias, artísticas e científicas como os direitos dos artistas intérpretes e executantes e os direitos dos produtores e das empresas de radiodifusão. Os programas de computador (softwares) são objeto de proteção especial, conferida pela Lei $n^{\circ} 9.609 / 1998$, que equipara os seus criadores aos autores de obras literárias, artísticas e científicas.

O direito industrial, por sua vez, cuida da proteção de patentes (de invenções e de modelos de utilidade), desenhos industriais e marcas e da repressão da concorrência 
desleal. A proteção das patentes e dos desenhos industriais é essencialmente patrimonial, pois não protege os direitos morais do autor, retribuindo com um título de patente a divulgação da criação feita pelo inventor e assim conferindo a este o direito de explorar com exclusividade a sua invenção, por um determinado período, como forma de recuperar os investimentos despendidos com pesquisa e desenvolvimento de novos produtos.

1.3 A ideia subjacente ao conceito de propriedade intelectual é que o inventor ou autor da criação a divulgue, dando conhecimento ao público, em troca de direito de exclusivo sobre a criação determinada. Ao conferir o direito de exclusivo ao titular da criação, o Estado deve prover mecanismos eficientes para assegurar a exclusividade na exploração, impedindo que terceiros utilizem indevidamente a criação divulgada, contrafazendo-a.

A contrafação abrange não só a reprodução idêntica como também outras formas de reprodução aproximada, não havendo distinção para a configuração da contrafação entre a contrafação parcial e a total, bastando a usurpação de quaisquer dos elementos essenciais constitutivos da criação protegida. Por esse motivo a comparação entre os objetos deve observar se existe reprodução dos elementos essenciais constitutivos do objeto protegido e pautar-se pelas semelhanças entre os dois objetos, e não pelas diferenças, pois as diferenças acrescidas não excluem a usurpação dos elementos essenciais.

A doutrina classifica quatro espécies de contrafação: a contrafação por cópia vil, ou seja, a simples cópia do objeto protegido (reprodução integral ou reprodução servil); a contrafação com alterações acessórias, em que o objeto incriminado tem pequenas diferenças mas reproduz os elementos essenciais do objeto protegido; a contrafação por equivalência, que ocorre quando um elemento da estrutura da invenção é substituído por um elemento distinto que desempenha a mesma função para alcançar um resultado semelhante; e a contrafação por aperfeiçoamento, quando se realiza um aperfeiçoamento no objeto de base, aderindo melhoramentos que aumentem a eficiência ou o melhorem em qualquer de suas características.

1.4 A contrafação por cópia vil (pirataria), hoje, é a principal problemática do direito autoral e do direito industrial, como resultado da evolução tecnológica e da consequente popularização dos mecanismos de produção e reprodução; dos custos de 
produção mais baixos decorrentes da ilegalidade e da informalidade da atividade; da facilidade de romper e reproduzir os mecanismos de segurança e de identificação; e da velocidade da indústria transnacional de cópias, que permite o lançamento simultâneo dos produtos originais e de suas versões piratas.

Entretanto, apesar de a problemática ser a mesma (pirataria), o sistema de proteção penal da propriedade imaterial é dividido conforme a espécie, e não de acordo com o tipo de contrafação, reduzindo a eficiência pela falta de isonomia entre os tipos de contrafação e pela falta de definição clara do que se pretende combater — a pirataria.

2.1 Atualmente, não faz sentido pensarmos na proteção dos direitos patrimoniais de propriedade intelectual como resguardo do criador, pois os direitos patrimoniais de propriedade imaterial, em regra, são alienados pelos autores/inventores para as empresas que controlam os meios de reprodução e distribuição.

2.2 Somado a isso, temos dificuldade de aplicar as sanções previstas aos camelôs que vendem os produtos piratas nos grandes centros comerciais, pela condição de miserabilidade deles, pela tolerância com o ilícito que viola os direitos das grandes companhias que controlam os canais de produção e distribuição e pelo alto custo dos produtos no mercado interno, que exclui da cadeia de consumo grande parte da população brasileira.

Com o nítido escopo de reverter essa tolerância com a pirataria, as associações que representam os interesses das indústrias cinematográfica, fonográfica e de software iniciaram forte campanha nos anos de 2001 a 2003, divulgando perdas de faturamento e de arrecadação e promovendo campanhas de conscientização que associavam a imagem do camelô à do traficante de armas e drogas. Tais campanhas tinham como objetivo romper a vitimização social da figura do ambulante e, ao mesmo tempo, associar a pirataria ao crime organizado, como forma de utilizar as medidas assecuratórias de bens previstas na Lei de Lavagem de Dinheiro. Entretanto, tal associação tornou-se desnecessária, pois em julho de 2012 a Lei $\mathrm{n}^{\circ} 12.683$ alterou a Lei de Lavagem de Dinheiro, revogando o rol taxativo de crimes antecedentes e estendendo os mecanismos de repressão para todas as infrações penais indiscriminadamente. 
2.3 A proteção penal da propriedade intelectual também foi modificada pela Lei $\mathrm{n}^{0}$ 10.695/2003, entretanto manteve-se a estrutura dividindo os tipos conforme a espécie de propriedade imaterial. A proteção permanece dividida em crimes de violação de direitos autorais (previstos no Código Penal), crimes de violação de direitos de autor de software (previstos na Lei $\mathrm{n}^{0}$ 9.609/1998) e crimes contra a propriedade industrial (disciplinados pela Lei $\left.n^{0} 9.279 / 1996\right)$.

Os crimes de violação de direitos autorais foram significativamente modificados, ampliando a proteção penal para os direitos de artistas executantes, produtores fonográficos e empresas de radiodifusão e introduzindo condutas específicas destinadas a coibir a pirataria de livros, filmes e álbuns musicais. Entretanto, as mudanças não solucionaram a falta de taxatividade dos dispositivos nem separaram adequadamente da proteção patrimonial a proteção moral de autor.

2.6 Como vimos, existe uma disparidade muito grande entre a proteção penal prevista para direitos de autor e direitos de autor de software e a proteção penal prevista para os direitos industriais. Tal desigualdade não pode ser justificada pela suposta diferença entre os titulares, uma vez que os direitos patrimoniais tanto de autor quanto de autor de software atualmente estão concentrados nas grandes empresas que detêm os mecanismos de reprodução e distribuição dos produtos. De igual forma, essa disparidade não se justifica pelo escopo, uma vez que as modificações introduzidas ao sistema para combater a pirataria deveriam abranger, de forma isonômica, os produtos industriais, os quais também são objeto de contrafação por reprodução servil (pirataria).

Se o escopo da Lei $n^{0} 10.695 / 2003$ era criar mecanismos aptos ao combate eficiente da pirataria, poderia ter revogado todos os dispositivos penais existentes, sistematizando a matéria de forma isonômica no próprio Código Penal pela introdução de um tipo específico para o combate à pirataria — de qualquer espécie de propriedade imaterial —, diferenciando as condutas cometidas pela internet e as condutas dos pequenos vendedores.

Para o processo penal, entretanto, a reforma da Lei $\mathrm{n}^{0} 10.695 / 2003$ trouxe uma mudança significativa, diferenciando o procedimento dos crimes de ação penal de iniciativa privada do procedimento dos crimes de ação penal de iniciativa pública. Para os primeiros manteve-se a sistemática anterior, enquanto para os de ação penal de iniciativa 
pública foi estabelecido um novo procedimento, que se diferencia do procedimento comum pela necessidade de produção antecipada de provas (exame pericial) e pela nova modalidade de apreensão, que deixou de ser um instrumento a serviço do processo e passou a ter natureza satisfativa.

3.1 No Brasil, as apreensões sempre foram disciplinadas em conjunto com as buscas, desde o Código de Processo Criminal do Império até a redação atual do artigo 240 do Código de Processo Penal, deixando de dar para a apreensão tratamento legislativo distinto, como se os institutos fossem indissociáveis um do outro. Ademais, em todas as constituições vigentes no país, a limitação mais importante à busca e à apreensão sempre foi a proteção da casa, que é asilo inviolável do indivíduo, local onde ele pode manifestar e desenvolver o seu direito à intimidade e à vida privada.

3.2 O conteúdo constitucional da inviolabilidade da casa, entretanto, não se restringe à definição do direito penal. Ele abrange: a habitação definitiva, ou morada transitória; a casa própria, alugada, ou cedida; as dependências da casa; qualquer compartimento habitado; o aposento ocupado de habitação coletiva em pensões, hotéis e pousadas; os estabelecimentos comerciais e industriais fechados ao público; o local onde se exerce atividade profissional não aberto ao público; os barcos, os trailers, as cabines de trem ou navio e as barracas de acampamento; e as áreas comuns de condomínio vertical ou horizontal.

Além da casa, as buscas e as apreensões devem respeitar, da forma mais abrangente possível, a proteção à intimidade e à vida privada dos indivíduos, observando os escopos previstos no mandado de busca, restringindo o varejamento aos objetos relacionados ao crime investigado e deixando incólumes os objetos que não estão relacionados com a infração penal.

3.3 A proteção da casa permitia o livre desenvolvimento da intimidade e da vida privada, garantindo ao sujeito desses direitos a proteção das atividades ali exercidas e das coisas guardadas naquele local. Entretanto, hoje, com o desenvolvimento de novas tecnologias, é possível entrar e varejar por meio da rede mundial de computadores, acessando e devassando fotos, documentos, vídeos, extratos bancários e correspondências sem sequer se aproximar fisicamente da casa do investigado. 
Atualmente, as comunicações telefônicas e as correspondências podem ser realizadas por meio de trocas de arquivos na internet, bem como qualquer informação escrita, sonora ou visual é passível de conversão e armazenamento em dados de computador, motivo pelo qual não se pode utilizar a inviolabilidade dos dados prevista na norma constitucional como forma de proteção ao exercício antiético e ilícito dessa liberdade pública. Logo, é lícito entender que os dados de computador são passíveis de apreensão, por ordem judicial, para fins de investigação criminal ou para a instrução de processo penal.

3.4.1 Por esse motivo podemos afirmar que estamos entrando em um segundo marco conceitual, no qual a proteção da intimidade e da vida privada por meio da regra da inviolabilidade da casa do indivíduo não é eficaz para proteger o indivíduo das intromissões realizadas por meio de dispositivos eletrônicos conectados com a rede mundial de computadores. Talvez a regra mais adequada para proteger a intimidade e a vida privada seja aquela pautada na expectativa de privacidade do indivíduo (teoria da expectativa de privacidade - Katz v. United States ${ }^{396}$ ).

3.4.3 Ademais, precisamos disciplinar o procedimento de buscas e apreensões digitais, estabelecendo a forma como elas devem ser realizadas para ao mesmo tempo garantir a sua eficiência e resguardar os direitos das pessoas que sofrem a medida restritiva de direitos fundamentais. Para isso, não basta que a apreensão esteja nominada, como no artigo 254 do Código de Processo Penal italiano ${ }^{397}$, alterado pela Lei $n^{\circ} 48$, de 18 de março de $2008^{398}$, é necessário disciplinar o procedimento.

3.4.2 As apreensões de todos os bens ilicitamente reproduzidos, como forma de combate à pirataria, no procedimento dos crimes contra a propriedade intelectual não são um fenômeno isolado do sistema brasileiro, também estão previstas no ordenamento jurídico argentino, por força das pressões internacionais e da recepção do TRIPs pela Lei $\mathrm{n}^{\mathrm{o}} 24.425^{399}$ daquele país.

\footnotetext{
396 UNITED STATES, 1967.

397 ITALIA, 1988.

398 ITALIA, 2008.

399 ARGENTINA, 1994 b.
} 
4.1 A dificuldade da doutrina em identificar a natureza jurídica da busca decorre de dois aspectos: primeiro, a unidade legislativa da busca e da apreensão; segundo, o dissenso classificatório. A busca, ato do procedimento penal, é restritiva de direitos individuais e consiste em revista ou varejamento, para encontrar e apreender (coisas, semoventes, vestígios ou pessoas), ou prender (pessoa), conforme o caso. A apreensão, por sua vez, é um ato processual penal complexo, que pode ser coercitivo (decorrente da busca ou da localização em locais públicos ou abertos ao público) ou voluntário (apresentação ou exibição da coisa com a respectiva entrega) e que implica sempre a constrição do direito de disposição de coisas, semoventes e pessoas, de quem as detém ou retém; por meio de apossamento, remoção e guarda, torna-os indisponíveis ou coloca-os sob custódia, enquanto forem necessários ao inquérito policial ou ao processo penal.

A busca, como medida instrumental restritiva de direitos fundamentais, tem natureza jurídica de meio de obtenção de prova (exceto nos casos de prisão), uma vez que qualquer meio de obtenção de prova pode ou não encontrar elementos de prova ou fontes de prova úteis ao processo. A apreensão, pelas mesmas razões, tem natureza jurídica de meio de obtenção de provas, porque serve tanto para descobrir e resguardar a fonte de prova como para obter elementos de prova, mas a medida de apreensão prevista no artigo 530-B do Código de Processo Penal não pode ser classificada apenas como tal, visto que se presta tanto à apreensão do corpo de delito quanto à apreensão de todos os bens ilicitamente produzidos ou reproduzidos.

4.2 As apreensões são medidas autônomas, que podem se efetivar como consequência das buscas ou de forma autônoma, pela exibição voluntária ou pelo encontro casual de pessoa, semovente ou coisa que deve ser apreendida. A ordem de apreensão decorrente de busca pode ser determinada de ofício ou mediante requerimento do Ministério Público, da autoridade policial, do ofendido, do presidente de comissão parlamentar de inquérito ou do próprio indiciado ou acusado. $\mathrm{O}$ mandado de apreensão deve indicar o que deve ser apreendido - ou, no mínimo, as espécies de coisas que se pretende procurar e apreender com a medida —, não sendo lícito expedir mandados de busca e de apreensão em branco.

A exibição voluntária autoriza a apreensão, mas deve ser observada a licitude, ou não, na obtenção da coisa exibida, a necessidade de retirá-la do poder de quem a retém e a 
imprescindibilidade, para a instrução criminal, do apossamento. Nesse caso, deve ser elaborado auto de exibição e apreensão fundamentado, em que constem a descrição minuciosa das coisas apreendidas e os motivos da apreensão.

O encontro casual pode ocorrer em duas situações: a primeira durante a execução de medida de busca, pelo encontro de coisas que não estão relacionadas com o processo que a ensejou; e a segunda pelo encontro de coisas em locais públicos ou abertos ao público. Em ambas as hipóteses, salvo no caso de flagrante delito, a melhor solução é que os executores da busca - ou a autoridade policial, no caso de encontro em locais públicos ou abertos ao público - preservem o local, providenciando a respectiva autorização judicial para a apreensão.

Se não for possível identificar o possuidor ou detentor das coisas achadas casualmente em locais públicos ou abertos ao público, não sendo necessária a inversão forçada da posse, entendemos que não há necessidade de ordem judicial para a apreensão, mas é imprescindível a realização de auto de apreensão, descrevendo a coisa detalhadamente, formalizando a apreensão e as respectivas condições em que a coisa foi encontrada e explicitando os motivos pelos quais foi impossível a identificação do possuidor ou detentor.

4.3 A apreensão no procedimento dos crimes contra a propriedade imaterial de ação penal de iniciativa privada foi disciplinada exclusivamente como meio de obtenção de provas, de natureza cautelar e instrumental, como medida preparatória para a ação penal. Nesses casos, o ofendido deve requerer ao juiz a busca e a apreensão das coisas que serão objeto do exame pericial, comprovando a titularidade do direito de exclusivo e oferecendo os quesitos à perícia. Em decorrência dessa natureza, a apreensão será realizada apenas sobre os exemplares estritamente necessários à realização da perícia.

No procedimento dos crimes contra a propriedade imaterial de ação penal de iniciativa pública a apreensão poderá recair sobre todos os bens ilicitamente produzidos ou reproduzidos e sobre equipamento, suporte ou material utilizado no cometimento da infração, desde que estes se destinem precipuamente à prática do ilícito. Por permitir a apreensão de todos os bens ilicitamente produzidos ou reproduzidos, a medida não se justifica como um instrumento processual, vez que não se restringe aos exemplares 
necessários ao exame pericial. Da mesma forma, é absolutamente inadmissível, em face do princípio da presunção de inocência, aceitar que as apreensões nesses casos sejam medidas de antecipação do juízo condenatório.

5.1 Podemos diferenciar as medidas cautelares das medidas satisfativas porque as primeiras visam tutelar o próprio processo, assegurando-lhe o regular desenvolvimento, ou a eficácia do provimento jurisdicional final, enquanto as segundas visam antecipar os efeitos da sentença definitiva. Logo, a medida de apreensão prevista no artigo 530-B do Código de Processo Penal é medida satisfativa, porque antecipa parte do provimento final, sobre as coisas que não podem ser restituídas.

5.2 O Código Penal prevê duas hipóteses de coisas que não podem ser restituídas (classificadas como confisco especial por Nelson Hungria), em casos de condenação, como efeito penal desta e, em casos de absolvição, impronúncia ou arquivamento de inquérito policial, como medidas de segurança patrimoniais. Nos casos de absolvição, se restringe aos objetos cuja fabricação, cuja venda, cujo uso, cujo porte ou cuja detenção constitua em si ilícito penal autônomo. Nos demais casos, quando os instrumentos ou os produtos do crime não forem proibidos por si mesmos, o confisco só pode ser imposto como efeito da condenação.

Portanto, em nenhum dos casos (condenação, absolvição, impronúncia ou arquivamento de inquérito policial) o juiz poderá determinar a restituição de armas ilegais, moedas falsas, documentos falsificados, substâncias entorpecentes e produtos piratas, porque a fabricação, a venda, o uso, o porte ou a detenção constitui ilícito autônomo, devendo determinar a destruição antecipada ou final de tais coisas, resguardando apenas a quantidade ou os exemplares necessários à prova ou à contraprova.

5.3 A apreensão introduzida pela Lei $\mathrm{n}^{0} 10.695 / 2003$ - que tinha por escopo estabelecer novos mecanismos de combate à pirataria — não é medida cautelar, pois não se destina à preservação do processo ou do provimento jurisdicional; pelo contrário, tem por escopo assegurar que todos os bens ilicitamente produzidos ou reproduzidos sejam retirados daquele que sofre a medida, depositando-os com os titulares de direitos de autor e conexos. 
Logo, só podemos entender que a medida tem natureza jurídica satisfativa, pois antecipa parte do provimento final sobre as coisas que não podem ser restituídas, retirando de circulação os exemplares de filmes, álbuns musicais e programas de computador contrafeitos, como instrumento de combate à pirataria. Mas a medida não pode ser justificada como uma antecipação da pena.

5.3.1 Apesar de essa nova modalidade de apreensão ser um instrumento valioso para garantir a eficiência do procedimento dos crimes contra a propriedade imaterial, não foi contemplada no PLS $n^{0} 156 / 2009$, pois não foi previsto procedimento especial para os crimes contra a propriedade imaterial e as buscas e apreensões foram disciplinadas apenas como meios de obtenção de provas. Paralelamente ao PLS n ${ }^{0}$ 156/2009, também está em tramitação outra proposta legislativa (Projeto de Lei $n^{0}$ 2.729/2003), que mantém a apreensão prevista no artigo 530-B do Código de Processo Penal e explicita a natureza jurídica satisfativa da medida.

5.3.2 A presunção de inocência como norma de tratamento pressupõe que os atos processuais respeitem o status de inocência do acusado, impedindo qualquer tratamento que afronte sua dignidade, bem como o uso de qualquer medida restritiva que antecipe a condenação. Entretanto, apesar da natureza tipicamente antecipatória ou satisfativa da apreensão prevista no artigo 530-B do Código de Processo Penal, não vemos óbice à sua manutenção no processual penal, pois ela não antecipa um juízo de condenação ou efeitos decorrentes exclusivamente da sentença condenatória.

Na verdade, a antecipação refere-se a um capítulo distinto da sentença, seja ela condenatória, seja absolutória, sobre os bens que não são passíveis de restituição e independe de qualquer juízo sobre a autoria ou a culpabilidade do acusado. Logo, a antecipação não implica a supressão do princípio da presunção de inocência, porque tanto em casos de condenação quanto em casos de absolvição as coisas apreendidas não poderão ser restituídas àqueles que as detinham ou retinham, quando a fabricação, a venda, o uso, o porte ou a detenção constitua ilícito autônomo.

5.3.3 Entretanto, apesar de a apreensão prevista no artigo 530-B do Código de Processo Penal não violar o princípio da presunção de inocência, permitindo a atuação 
eficaz dos órgãos encarregados da persecução penal, deve se assegurar, ao mesmo tempo, um procedimento que observe as garantias constitucionais do imputado.

Por esse motivo, entendemos que deveria existir, no procedimento dos crimes contra a propriedade imaterial de ação de iniciativa pública, um ato de constatação da ilicitude das cópias apreendidas, aplicando-se por analogia a obrigatoriedade do auto de constatação previsto no procedimento da Lei de Drogas, para aumentar a certeza do provimento jurisdicional antecipatório ou satisfativo.

Além disso, uma vez que a medida antecipa parte do provimento jurisdicional final, entendemos que seria imprescindível a existência de ordem judicial que determinasse a apreensão, ou, nos casos de prisão em flagrante, a remessa, ao juiz, da cópia do auto de prisão em flagrante devidamente instruída com a cópia do auto de apreensão e do respectivo auto de constatação, para a apreciação da legalidade da medida de apreensão.

Com isso, entendemos que estaria assegurado o direito ao processo penal justo, por meio de um procedimento eficiente e garantista, aparelhado com uma medida de apreensão de todos os objetos pirateados, garantindo, de um lado, o pleno exercício dos direitos de defesa e, de outro, medidas eficientes no combate à pirataria. 


\section{REFERÊNCIAS}

ALEXY, Robert. Teoría de los derechos fundamentales. Madrid: Centro de Estúdios Políticos y Constitucionales, 1997.

ALMEIDA, José Raul Gavião de. Anotações acerca do direito à privacidade. In: MIRANDA, Jorge; SILVA, Marco Antônio Marques da. (Org.). Visão luso-brasileira da dignidade humana. São Paulo: Quartier Latin, 2008. v. 1.

AMATO, Giuseppe. Codice di procedura penale, rassegna di giurisprudenza e di dottrina. Milano: Giuffrè, 1998. livro 4.

AMODIO, Ennio. Libero convincimento e tassatività dei mezzi di prova: un approccio comparativo. Rivista Italiana di Diritto e Procedura Penale, Milano, v. 42, n. 1, p. 3-9, gen./mar. 1999.

AMODIO, Enio; BASSIOUNI, M. Cherif. Il processo penale negli stati uniti d'America. Milano; Giuffrè, 1988.

ANDRADE, Paes de; BONAVIDES, Paulo. História constitucional do Brasil. 3. ed. Rio de Janeiro: Paz e Terra, 1991.

ARANHA, Adalberto José Q. T. de Camargo. Da prova no processo penal. 7. ed. São Paulo: Saraiva, 2006.

ARAUJO, José Laércio. Intimidade, vida privada e direito penal. São Paulo: Habeas, 2000.

ÁVILA. C. et al. El sistema procesal penal español. In. HENDLER, Edmundo S (Org.). Sistemas procesales penales comparados. Buenos Aires: Ad-Hoc, 1999.

BADARÓ, Gustavo Henrique Righi Ivahy. Direito processual penal. Rio de Janeiro: Elsevier, 2008. tomo 1.

BADARÓ, Gustavo Henrique Righi Ivahy. Ônus da prova no direito processual penal brasileiro. 2002. 488 f. Tese (Doutorado em Direito)- Faculdade de Direito, Universidade de São Paulo, São Paulo, 2002.

BADARÓ, Gustavo Henrique Righi Ivahy. Provas atípicas e provas anômalas: inadmissibilidade da substituição da prova testemunhal pela juntada de declarações escritas de quem poderia ser testemunha. In: YARSHELL, Flávio Luiz; MORAES, Maurício Zanóide (Orgs.). Estudos em homenagem à professora Ada Pellegrini Grinover. São Paulo: DPJ, 2005.

BARBOSA, Denis Borges. Da doutrina dos equivalentes em direito de patentes. Disponível em: <http://denisbarbosa.addr.com/equivale.pdf $>$. Acesso em: 29 maio 2011.

BARBOSA, Denis Borges. Tratado da propriedade intelectual. Rio de Janeiro: Lumen Juris, 2010. tomo 1. 
BARBOSA, Denis Borges. Uma introdução à propriedade intelectual, Rio de Janeiro: Lumens Júris, 2003.

BARBOSA MOREIRA, José Carlos. Temas de direito processual: segunda série. São Paulo: Saraiva, 1988.

BASSO, Maristela. Propriedade intelectual e importação paralela. São Paulo: Editora Atlas, 2011.

BECHARA, Fábio Ramazzini; MANZANO, Luís Fernando de Moraes. Crime organizado e terrorismo nos Estados Unidos da América. In: FERNANDES, Antonio Scarance; ALMEIDA, José Raul Gavião de; MORAES, Maurício Zanoide de. (Orgs.). Crime organizado: aspectos processuais. São Paulo: Revista dos Tribunais, 2009. p. 153-184.

BEDAQUE, José Roberto dos Santos. Efetividade do processo e técnica processual. São Paulo: Malheiros, 2006.

BEDAQUE, José Roberto dos Santos. Tutela cautelar e tutela antecipada: tutelas sumárias e de urgência. 3. ed. São Paulo: Malheiros, 2003.

BONAVIDES, Paulo; ANDRADE, Paes de. História constitucional do Brasil. 3. ed. Rio de Janeiro: Paz e Terra, 1991.

BRASIL. Relatório da Comissão Parlamentar de Inquérito. Finalidade: investigar fatos relacionados à pirataria de produtos industrializados e à sonegação fiscal. Brasília, 2004. Disponível em: <http://www2.camara.leg.br/atividade-legislativa/comissoes/comissoestemporarias/parlamentar-de-inquerito/52-legislatura/cpipirat/relatoriofinal.pdf $>$. Acesso em: 30 dez. 2012.

BURINI, Bruno. Efeitos civis da sentença penal. São Paulo: Atlas, 2007.

BUSCA. In: HOUAISS, Antônio; VILLAR, Mauro de Salles; FRANCO, Francisco Manoel de Mello. Houaiss Dicionário da Língua Portuguesa. Rio de Janeiro: Objetiva, 2001.

CAFFERATA NORES, José Ignacio; HARAIBEDIÁN, Maximiliano. La prueba em el proceso penal: com especial referencia a los Códigos PPN y de La Província de Córdoba. 6. ed. Buenos Aires: Lexis Nexis Argentina, 2008.

CAMPANHA combate pirataria intelectual. O Estado de São Paulo Online, São Paulo, 19 mar. 2002. Caderno 2. Disponível em: $<\mathrm{http} / / /$ www.estadao.com.br/arquivo/arteelazer/2002/not20020319p3288.htm>. Acesso em: 10 jan. 2013.

CAMPANHA liga pirataria ao crime organizado. O Estado de São Paulo Online, São Paulo, 16 abr. 2003. Tecnologia. Disponível em: $<$ http://www.estadao.com.br/arquivo/tecnologia/2003/not20030416p44544.htm>. Acesso em: 10 jan. 2013. 
CANOTILHO, J. J. Gomes. Direito constitucional e teoria de constituição. 5. Ed. Coimbra: Almedina, 2002.

CARBONI, Guilherme C. A lei 10.695/03 e seu impacto no direito autoral brasileiro. Jus Navigandi, Separata F 63, p. 3, ago. 2003. Disponível em: $<$ http://jus.com.br/revista/texto/4432/a-lei-no-10-695-03-e-seu-impacto-no-direito-autoralbrasileiro>. Acesso em: 3 dez. 2012.

CARNELUTTI, Francesco. Istituzioni del processo civile italiano. 5. ed. Roma: Foro Italiano, 1953. v. 1.

CARVAlHO, Luis Gustavo Grandinetti Castanho de. Processo penal em face da constituição. Rio de Janeiro: Forense, 1992.

CATINO, Paola. El allanamiento. Buenos Aires: Fabián J. Di Plácido Editor, 2007.

CERQUEIRA, João da Gama. Tratado da propriedade industrial. Rio de Janeiro: Lumen Juris, 2010a. v. 1.

CERQUEIRA, João da Gama. Tratado da propriedade industrial. Rio de Janeiro: Lumen Juris, 2010b. v. 2, tomo 1.

CERQUEIRA, João da Gama. Tratado da propriedade industrial. Rio de Janeiro: Lumen Juris, 2010c. v. 2, tomo 2.

CHADE, Jamil. SOUZA, Nilza. País pede revisão em direito autoral. O Estado de São Paulo, p. A18, 23 set. 2008.

CHIAVARIO, Mario; DELEUZE, B.; DELMAS-MARTY, Mireille. Procedure penali d'Europe: Belgio, Francia, Germania - Inghilterra - Italia. Milano: CEDAM, 2001.

CINTRA, Antonio Carlos de Araújo; GRINOVER, Ada Pelegrini; DINAMARCO, Cândido Rangel. Teoria geral do processo. 17. ed. São Paulo: Malheiros, 2001.

CLARIÁ OLMEDO, Jorge A. Tratado de derecho procesal penal. Buenos Aires: Ediar, 1966. tomo 5 .

COLLAÇO, Rodrigo. Pirataria e lavagem de dinheiro. In: SEMINÁRIO NACIONAL DA PROPRIEDADE INDUSTRIAL, 27., 2007, Rio de Janeiro. Anais... Rio de Janeiro: ABPI, 2007.

COMPUTAÇÃO em nuvem. In: WIKIPÉDIA. Disponível em: $<$ http://pt.wikipedia.org/wiki/Computação_em_nuvem>. Acesso em: 12 dez. 2012.

CORRÊA JUNIOR, Alceu. Confisco penal: alternativa à prisão e aplicação aos delitos econômicos. São Paulo: IBCCRIM, 2006. (Monografias, 37).

COSTA JR., Paulo José. O direito de estar só. 4. ed. São Paulo: Revista dos Tribunais, 2007. 
CRUZ e TUCCI, José Rogério. Tempo e processo. São Paulo: Revista dos Tribunais, 1997.

DALIA, Andrea Antonio; FERRAIOLI, Marzia. Manuale di diritto processuale penale. 4. ed. Padova: CEDAM, 2001.

DEZEM, Guilherme Madeira. Da prova penal: tipo processual, provas típicas e atípicas. Campinas: Millennium, 2008.

DINAMARCO, Cândido Rangel. A instrumentalidade do processo. 10 ed. São Paulo: Malheiros, 2002.

DINAMARCO, Cândido Rangel. Capitulos de sentença. São Paulo: Malheiros, 2009.

DINAMARCO, Cândido Rangel. O regime jurídico das medidas urgentes. Revista Jurídica, Porto Alegre, v. 49, n. 286, p. 271-302, ago. 2001.

DINAMARCO, Cândido Rangel; ARAÚJO CINTRA, Antonio Carlos de; GRINOVER, Ada Pellegrini. Teoria geral do processo. São Paulo: Malheiros, 1998.

DINI, Roberto. Le origini della proprietà intellettuale. In: Proprietà intellettuale: uno strumento per la crescita economica nel terzo millennio. Roma: LES Italia, 2010. p. 717.

DINIZ, Maria Helena. Dicionário jurídico. São Paulo: Saraiva, 1998.

DIPP, Gilson. Pirataria e lavagem de dinheiro. In: SEMINÁRIO NACIONAL DA PROPRIEDADE INDUSTRIAL, 27., 2007, Rio de Janeiro. Anais... Rio de Janeiro: ABPI, 2007.

DORIA, Pedro. Somos todos piratas criminosos? O Estado de São Paulo, p. L11, 23 jun. 2008.

DOTTI, René Ariel. Proteção da vida privada e liberdade de informação: possibilidades e limites. São Paulo: Revista dos Tribunais, 1980.

ENTENDA como funciona o sistema torrent para compartilhar arquivos na web. Folha Online. São Paulo, 17 abr. 2009. Disponível em: $<$ http://www1.folha.uol.com.br/folha/informatica/ult124u552200.shtml $>$. Acesso em: 30 dez. 2012.

ESPÍNOLA FILHO, Eduardo. Código de Processo Penal Brasileiro anotado. Rio de Janeiro: Livraria Freitas Bastos, 1942.

ESPINOLA FILHO, Eduardo. Código de Processo Penal brasileiro anotado. 3. ed. Rio de Janeiro: Livraria Freitas Bastos, 1942. v. 3.

ESTEFAM, André. Provas e procedimentos no processo penal. São Paulo: Damásio de Jesus, 2008.

FARIA, José Eduardo. O direito na economia globalizada. São Paulo: Malheiros, 1999. 
FEBRABAN. Pronunciamentos 19/08/2011. Perdas com fraudes eletrônicas aumentam $36 \%$ no primeiro semestre de 2011. Disponível em: $<$ http://www.febraban.org.br/Noticias1.asp?id_texto=1321>. Acesso em: 6 jul. 2012.

FERNANDES, Antonio Scarance. Efetividade, processo penal e dignidade humana. In: MIRANDA, Jorge; SILVA, Marco Antonio Marques da (Coords.). Tratado luso-brasileiro da dignidade humana. 2. ed. São Paulo: Quartier Latin, 2009.

FERNANDES, Antonio Scarance. O equilíbrio na repressão ao crime organizado. In: FERNANDES, Antonio Scarance; ALMEIDA, José Raul Gavião de; MORAES, Maurício Zanoide de. (Orgs.). Crime organizado: aspectos processuais. São Paulo: Revista dos Tribunais, 2009. p. 9-28.

FERNANDES, Antonio Scarance. O papel da vítima no processo criminal. São Paulo: Malheiros, 1995.

FERNANDES, Antonio Scarance. Processo penal constitucional. 6. ed. São Paulo: Revista dos Tribunais, 2010.

FERNANDES, Antonio Scarance. Prova e sucedâneos da prova no processo penal. Revista Brasileira de Ciências Criminais, São Paulo, n. 66, n. 4, p. 193-236, 2007.

FERNANDES, Antonio Scarance. Reflexões sobre as nações de eficiência e de garantismo no processo penal. In: FERNANDES, Antonio Scarance; ALMEIDA, José Raul Gavião de; MORAIS, Maurício Zanoide de. (Orgs.). Sigilo no processo penal, eficiência e garantismo. São Paulo: Revista dos Tribunais, 2008. p. 9-28. p. 13.

FERNANDES, Antonio Scarance. Teoria geral do procedimento e o procedimento no processo penal. São Paulo: Revista dos Tribunais, 2005.

FERNANDES, Antonio Scarance. Tipicidade e sucedâneos de prova. In: FERNANDES, Antonio Scarance; ALMEIDA, José Raul Gavião de; MORAES, Maurício Zanoide de (Coords.). Provas no processo penal: estudo comparado. São Paulo: Saraiva, 2011. p. 1345. p. 28-29.

FERNANDES, Antonio Scarance; GRINOVER, Ada Pellegrini; GOMES FILHO, Antonio Magalhães. As nulidades no processo penal. 6. ed. São Paulo: Revista dos Tribunais, 1998.

FERRAJOLI, Luigi. Derecho y razón: teoria del garantismo penal. Madri: Trotta, 2000.

FERREIRA, Ivette Senise. A intimidade e o direito penal. Revista Brasileira de Ciências Criminais, São Paulo, v. 5, p. 96-106, 1994.

GARCIA, Balmes Vega. Contrafação de patentes. São Paulo: Ltr, 2004.

GARCIA, Basileu. Comentários ao Código de Processo Penal. Rio de Janeiro: Revista Forense, 1945. v. 3. 
GOMES FILHO, Antonio Magalhães. A motivação das decisões penais. São Paulo: Revista dos Tribunais, 2001.

GOMES FILHO, Antonio Magalhães. Notas sobre a terminologia da prova (reflexos no processo penal brasileiro). In: YARSHELL, Flávio Luiz; MORAES, Maurício Zanoide de (Orgs.). Estudos em homenagem à professora Ada Pellegrini Grinover. São Paulo: DPJ, 2005. p. 303-318.

GOMES FILHO, Antonio. O princípio da presunção de inocência na constituição de 1988 e na convenção americana sobre direitos humanos (pacto de São José da Costa Rica). Revista do Advogado, São Paulo, n. 42, p. 30-34, 1994.

GOMES FILHO, Antonio Magalhães; FERNANDES, Antonio Scarance; GRINOVER, Ada Pellegrini. As nulidades no processo penal. 6. ed. São Paulo: Revista dos Tribunais, 1998.

GOMES, Luiz Flávio. Lei de drogas comentada: artigo por artigo - lei 11.343, de 23.08.2006. 3. ed. São Paulo: Revista dos Tribunais, 2008. p. 294.

GOMES, Luiz Flavio, CERVINI, Raúl. Crime organizado, enfoques criminológico, jurídico (Lei 9.034/95) e político criminal. São Paulo: Revista dos Tribunais, 1995.

GONÇALVES, Marcel Figueiredo. Vendedor ambulante, contrafação de mídias e acumulação. Boletim IBCCrim, São Paulo, n. 209, v. 17, p. 6-7, 2010

GRINOVER, Ada Pelegrini. A reforma do código de processo penal. In: A reforma do processo penal. III Jornadas Brasileiras de Direito Processual Penal. Brasília, Anais, Revista dos Tribunais, 2000.

GRINOVER, Ada Pellegrini. Liberdades públicas e processo penal: as interceptações telefônicas. 2. ed. São Paulo: Revista dos Tribunais, 1982.

GRINOVER, Ada Pellegrini. Novas tendências do direito processual. São Paulo: Forense Universitária, 1990.

GRINOVER, Ada Pelegrini; DINAMARCO, Cândido Rangel; ARAÚJO CINTRA, Antonio Carlos de. Teoria geral do processo. São Paulo: Malheiros, 1998.

GRINOVER, Ada Pelegrini; FERNANDES, Antonio Scarance; GOMES FILHO, Antonio Magalhães. As nulidades no processo penal. 6. ed. São Paulo: Revista dos Tribunais, 1998.

GUERRA FILHO, Willis Santiago. Processo constitucional e direitos fundamentais. 2. ed. São Paulo: Celsos Bastos Editor, 2001.

HALLEWELL, Laurence. O livro no brasil: sua história. 2. ed. São Paulo: Edusp, 2005.

HENDLER, Edmundo S. Sistemas procesales penales comparados. Buenos Aires: Ad-Hoc, 1999. 
HUNGRIA, Nelson. Comentários ao código penal. 4. ed. Rio de Janeiro: Forense, 1958. v. 1. tomo 2 .

HUNGRIA, Nelson. Comentários ao código penal (Dec.-lei $n^{\circ} 2.848$, de 7 de dezembro de 1940). 4. ed. Rio de Janeiro: Forense, 1959. v. 3.

INSTITUTO DANNEMANN SIEMSEM DE ESTUDOS DA PROPRIEDADE INTELECTUAL. Comentários à lei da propriedade industrial. Rio de Janeiro: Renovar, 2005.

IOKOI, Pedro Ivo Gricoli. Prisão preventiva e princípio da proporcionalidade. São Paulo: Dissertação de Mestrado, Faculdade de Direito, Universidade de São Paulo, 2005

JESUS, Damásio Evangelista de. A medida cautelar de busca e apreensão (parecer). Revista Brasileira de Ciências Criminais, São Paulo, v. 4, p. 294-300, 1996.

LACKNER, Ricardo. Aspectos penales de la ley de patentes n. 17.164. Revista de Derecho Penal, Montevideo, v. 13, p. 439-456, 2002.

LESSIG, Lawrence. O problema não são os piratas - é a lei. Entrevistado por Alexandre Matias e Rodrigo Martins. O Estado de São Paulo, São Paulo, 2 fev. 2009. Vida digital, p. L8.

LOPES JR., Aury. Direito processual penal e sua conformidade constitucional. 5. ed. Rio de Janeiro: Lumen Juris, 2010. v. 1.

MAIER, Julio B. J. Derecho procesal penal: fundamentos. 2. ed., 3. reimp. Buenos Aires: Editores Del Puerto, 2004.

MARQUES, José Frederico. Elementos de direito processual penal. 2. ed. Campinas: Milenium, 2000. v. 4.

MENDES JR., João de Almeida. O processo criminal brasileiro. Rio de Janeiro: Typografia Batista de Souza, 1920. v. 2.

MIRABETE, Julio Fabbrini. Processo penal. 17. ed. São Paulo: Atlas, 2005.

MONTEIRO, Clóvis da Silva. O fenômeno da pirataria de propriedade intelectual. In: SEMINÁRIO NACIONAL DA PROPRIEDADE INDUSTRIAL, 22., 2002, Rio de Janeiro. Anais... Rio de Janeiro: ABPI, 2002.

MORAES, Rubens Borba de. A impressão régia do Rio de Janeiro: origens e produção. In: CAMARGO, Ana Maria de Almeida. Bibliografia da impressão régia do Rio de Janeiro. São Paulo: Edusp, 1993. p. 17-31.

MORAES, Rubens Borba de. O bibliófilo aprendiz. 4. ed. Rio de Janeiro: Casa da Palavra, 2005.

MURTA FILHO, Antonio, Aspectos penais inovadores da recente lei 9.609, de 19/2/98. Revista da ABPI, Rio de Janeiro, n. 29, p. 29-33, 1997. 
NOGUEIRA, Paulo Lúcio. Curso completo de processo penal. 2. ed. São Paulo: Saraiva, 1986.

NORONHA, Edgard Magalhães. Curso de direito processual penal. 8. ed. São Paulo: Saraiva, 1976.

NUCCI, Guilherme de Souza. Provas no processo penal. 2. ed. São Paulo: Revista dos Tribunais, 2011.

PASCHOAL, Janaina Conceição. Tudo em nome dos direitos autorais. Boletim IBCCrim, São Paulo, n. 149, v. 12, p. 16-17, 2005.

PELLEGRINI, Angiolo; COSTA JR., Paulo José. Criminalidade organizada. 2. ed. São Paulo: Atlas, 2008.

PEREIRA, Alexandre Libório Dias. Inovação tecnológica, propriedade intelectual e defesa da concorrência no mercado de software. Boletim da Faculdade de Direito da Universidade de Coimbra, Coimbra, v. 85, p. 237-259, 2009.

PEREIRA, Alexandre Libório Dias. Propriedade intelectual, concorrência desleal e sua tutela (penal) em Portugal. Revista da Associação Brasileira de Propriedade Intelectual, Rio de Janeiro, n. 56, p. 15-34, 2002.

PHILIPP, Fernando Eid. Patente de invenção: extensão da proteção e hipóteses de violação. São Paulo: Juarez de Oliveira, 2006.

PIERANGELI, José Henrique. Crimes contra a propriedade industrial e crimes de concorrência desleal. São Paulo: Revista dos Tribunais, 2003.

PIMENTA, Eduardo; PIMENTA, Rui Caldas. Dos crimes contra a propriedade intelectual. 2. ed. São Paulo: Revista dos Tribunais, 2005.

PINHEIRO-MACHADO, Rosana. Made in China: produção e circulação de mercadorias no circuito China-Paraguai-Brasil. 2009. 332 f. Tese (Doutorado em Antropologia Social) - Instituto de Filosofia e Ciências Humanas, Universidade Federal do Rio Grande do Sul, Porto Alegre, 2009.

PITOMBO, Cleunice A. Valentim Bastos. A desfuncionalização da busca e da apreensão. Boletim IBCCRIM, São Paulo, v. 13, n. 151, p. 2-3, 2005.

PITOMBO, Cleunice A. Valentim Bastos. Da busca e da apreensão no processo penal. 2. ed. rev., atual. e amp. São Paulo: Revista dos Tribunais, 2005. (Coleção estudos de processo penal Joaquim Canuto Mendes de Almeida, v. 2).

PITOMBO, Sérgio Marques de Moraes. Do sequestro no processo penal brasileiro. São Paulo: José Bushatsky, 1973,

POLO, Giovana. Busca e apreensão pessoal e prova ilícita. Boletim IBCCRIM, São Paulo, v. 8, n. 92, p. 9, 2000. 
PREITE SOBRINHO, Wanderley. Acervo da família real portuguesa contribui para criação da Biblioteca Nacional. Folha Online, São Paulo, 3 mar. 2008. Disponível em: $<$ http://www1.folha.uol.com.br/folha/brasil/ult96u374639.shtml $>$. Acesso em: 15 jul. 2012 .

RAMOS, João Gualberto Garcez. Curso de processo penal norte-americano. São Paulo: Revista dos Tribunais, 2006.

REBÊLO, Paulo. Blu-ray e HD-DVD: entenda as diferenças e veja se vale investir. $U O L$, São Paulo, 2 mar. 2007. Disponível em: $<$ http://tecnologia.uol.com.br/ultnot/2007/03/02/ult4213u43.jhtm>. Acesso em: 29 dez. 2012.

RIQUERT, Marcelo Alfredo. Comentario de la ley 25.036 de protección penal del software. Cuadernos de doctrina y jurisprudencia penal, Buenos Aires, Ano 5, v. 8-c, p. 633-655, 1999.

SANTOS, Manoel J. Pereira dos. A nova lei do software: aspectos controvertidos da proteção autoral. Revista da ABPI, Rio de Janeiro, n. 29, p. 21-28, 1997.

SCHMIDT, Lelio Denicoli. A busca e apreensão nos crimes contra a propriedade industrial: requisitos para a concessão e responsabilidade pela execução. Revista da Associação Brasileira da Propriedade Intelectual, Rio de Janeiro, n. 43, p. 25-38, 1999.

SERRANO, Nicolas Gonzalez-Cuellar. Proporcionalidad y derechos fundamentales en el proceso penal. Madrid: Colex, 1990.

SILVA, De Plácido. Vocabulário jurídico. 15. ed. Rio de Janeiro: Forense, 2004.

SILVEIRA, Newton. Comentários à nova lei de direito autoral n. 9.610 de 19 de fevereiro de 1998. Revista da ABPI, Rio de Janeiro, n. 31, p. 35-40, 1997.

SILVEIRA, Newton. Estudos e pareceres de propriedade intelectual. Rio de Janeiro: Editora Lumen Juris, 2008.

SILVEIRA, Newton. Propriedade intelectual: propriedade industrial, direito de autor, software, cultivares, nome empresarial. 4. ed. rev. e ampl. Barueri: Manole, 2011.

SIRACUSANO, Delfino. Diritto processuale penale. Milano: Giuffrè, 2006. v. 1.

SOUZA, Diego Fajardo Maranha Leão de. Busca e apreensão digital: prova penal atípica. Boletim IBCCrim, São Paulo, n. 181, v. 15, p.14-15, 2007.

TONINI, Paolo. A prova no processo penal italiano. São Paulo: Revista dos Tribunais, 2002.

TONINI, Paolo. Manuale di procedura penale. 8. ed. Milano: Dott. A. Giuffrè, 2007.

TORNAGHI, Hélio. Instituições de processo penal. 2. ed. São Paulo: Saraiva, 1977. v. 3. 
TOURINHO FILHO, Fernando da Costa. Processo penal. 8. ed. rev. e atual., principalmente em face das Leis $n^{\circ} 7.209 / 84$ (Parte geral do CP) e 7.210/84 (Lei de Execução Penal). São Paulo: Saraiva, 1986. v. 3.

UNIÃO BRASILEIRA DE VÍDEO. Campanhas UBV. Disponível em: $<$ http://www.ubv.org.br/imprensa/campanhas>. Acesso em: 30 dez. 2012

VANZOLINI, Maria Patricia. Crimes contra a propriedade imaterial: comentários às alterações do código penal e do código de processo penal. In: GOMES, Luiz Flávio; VANZOLINI, Maria Patricia. Reforma criminal. São Paulo: Revista dos Tribunais, 2004. p. 43-90.

VIANNA, Túlio Lima. A ideologia da propriedade intelectual: a inconstitucionalidade da tutela penal dos direitos patrimoniais do autor. Revista Síntese de Direito Penal e Processual Penal, Porto Alegre, v. 6, n. 33, p. 7-22, ago./set. 2005.

VIANNA, Túlio Lima. A inconstitucionalidade da criminalização da pirataria. MPMG Jurídico, Belo Horizonte, v. 2, n. 7, p. 52-53, out./dez. 2006.

ZANAGA, Mariângela Pisoni. Conteúdos abertos na educação motivações e visão de autoria. 2006. 192 f. Tese (Doutorado em Educação) - Faculdade de Educação, Universidade Estadual de Campinas, Campinas, 2006.

ZANOIDE DE MORAES, Maurício. Presunção de inocência no processo penal brasileiro: análise de sua estrutura normativa para a elaboração legislativa e para a decisão judicial. Rio de Janeiro: Lumen Juris, 2010. 